Development of An Advanced, Continuous Mild Gasification Process for the Production of Co-Products (Task 4.7), Volume III

Final Report

\title{
R.A. Knight
}

J.L. Gissy

M. Onischak

S.P. Babu

R.H. Carty

R.G. Duthie (Bechtel Group, Inc.)

J.M. Wootten (Peabody Holding Co. Inc.)

September 1991

Work Performed Under Contract No.: DE-AC21-87MiC24266

For

U.S. Department of Energy

Office of Fossil Energy

Morgantown Energy Technology Center

Morgantown, West Virginia

By

Institute of Gas Technology

Chicago, Illinois 


\section{DISCLAIMER}

This report was prepared as an account of work sponsored by an ageucy of the United States Government. Neither the United States Government nor any agency thereof, nor any of their employees, makes any warranty, express or implied, or assumes any legal liability or responsibility for the accuracy, completeness, or usefulness of any information, apparatus, product, or process disclosed, or represents that its use would not infringe privately owned rights. Reference herein to any specific commercial product, process, or service by trade name, trademark, manufacturer, or otherwise does not necessarily constitute or imply its endorsement, recommendation, or favoring by the United States Government or any agency thereof. The views and opinions of authors expressed herein do not necessarily state or reflect those of the United States Government or any agency thereof.

This report has been reproduced directly from the best available copy.

Available to DOE and DOE contractors from the Office of Scientific and Technical Information, P.O. Box 62, Oak Ridge, TN 37831; prices available from (615)576.8401,

Available to the public from the National Technical Information Service, U.S. Department of Commerce, 5285 Port Royal Rd., Springfield, VA 22161. 
Development of An Advanced, Continuous Mild Gasification Process for the Production of Co-Products (Task 4.7),

\title{
Volume III
}

Final Report

\author{
R.A. Knight \\ J.L. Gissy \\ M. Onischak \\ S.P. Babu \\ R.H. Carty
}

R.G. Duthie (Bechtel Group, Inc.)

J.M. Wootten (Peabody Holding Co. Inc.)

Work Performed Under Contract No.: DE-AC21-87MC24266

For

U.S. Department of Energy

Office of Fossil Energy

Morgantown Energy Technology Center

P.O. Box 880

Morgantown, West Virginia 26507-0880

\author{
By \\ Institute of Gas Technology \\ IIT Center, 3424 S. State Street \\ Chicago, nlinois 60616
}

September 1991 
Volume I

Project Summary

Literature Survey of Mild Gasification Processes,

Co-Product Upgrading and Utilization, and Market

Assessment (Program Task 1)

Volume II

Mild Gasification Technology Development:

Process Research Unit Tests Using Slipstream Sampling

(Program Task 2)

Bench-Scale Char Upgrading Study

(Program Task 3)

Mild Gasification Technology Development:

System Integration Studies

(Program Tasks 4.1 to 4.6 )

Volume III

Mild Gasification Technology Development:

24 Ton Per Day Process Development Unit Design

and Cost Estimates (Program Task 4.7) 


\section{TABLE OF CONTENTS}

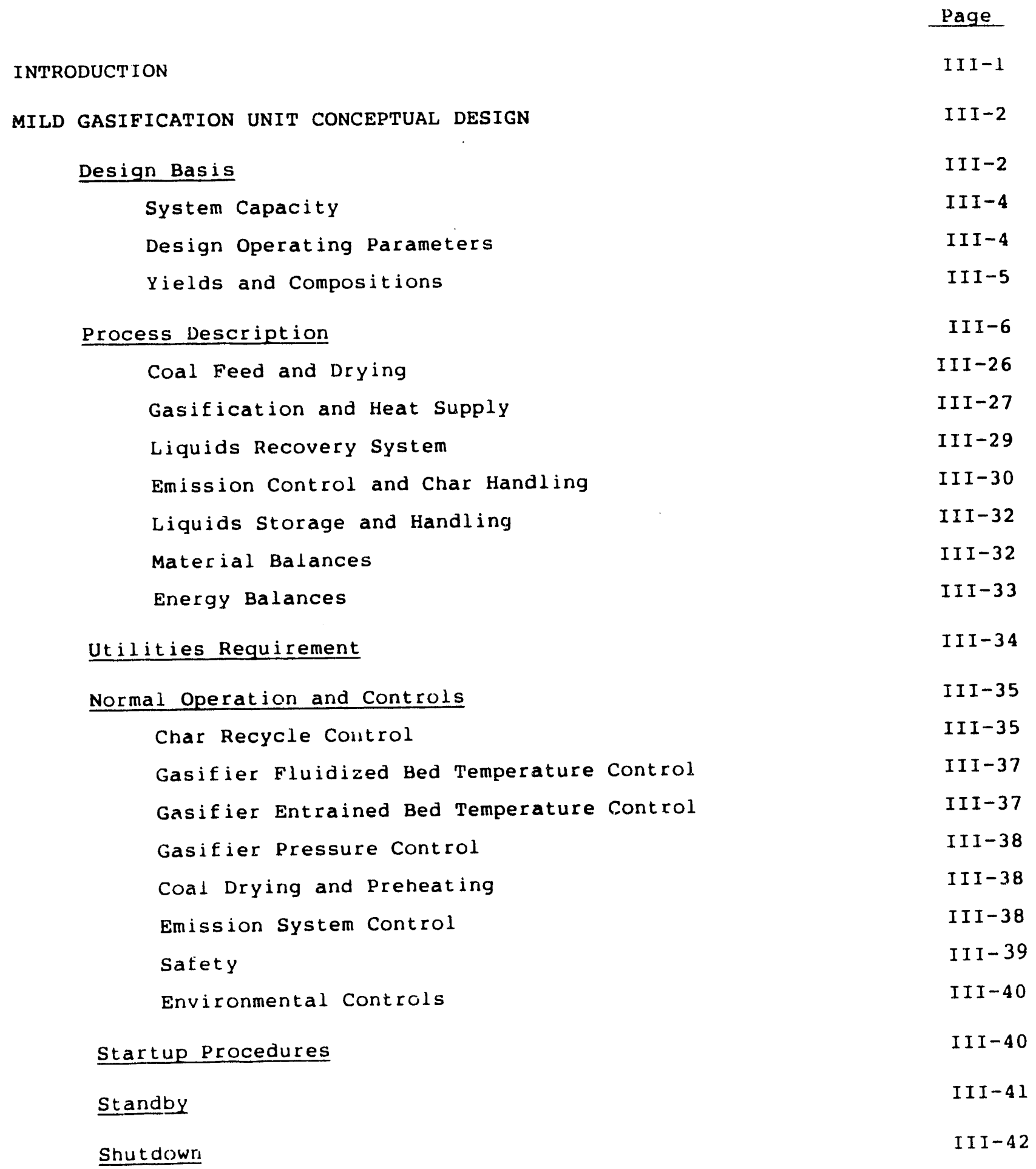


TABLE OF CONTENTS, Cont.

Approach to Steady State Following Startup and/or Feed Change
Special Equipment Designs
Coal Dryer and Preheater
Gasifier
Hot Gas/Char Fines Separation
Char Heater
Thermal Cracker
Tar Recovery

III -43

I I I -45

III -45

I I I -45

FORM COKE PROCESS CONCEPTUAL DESIGN

I I -46

Design Basis

I I -46

System Capacity

I I I -46

Design Operating Parameters

III -46

Yields and Compositions

I I I -46

Process Description

I I -49

Feed Preparation

I I -49

Material Balance

I I I -56

Energy Balance

I I I -56

Ut ilities Requirements

I I I -57

Normal Operation and Controls

I I I -58

Mixer/Heater Temperature Control

I I I -60

Calciner Temperature Control

I I I -60

Incinerator Temperature Control

I I I -60

pressure Control

I I I -6 I

Startup procedures

I I I -6 I

Standby.

I I I -62

Shutdown

I I I -63

I I I -63

Special Equipment Designs

I I I -63

Mixer/Heater

I I I -63

Hot Roll Briquetter

I I I -64

Calciner 
TABLE OF CONTENTS, Cont.

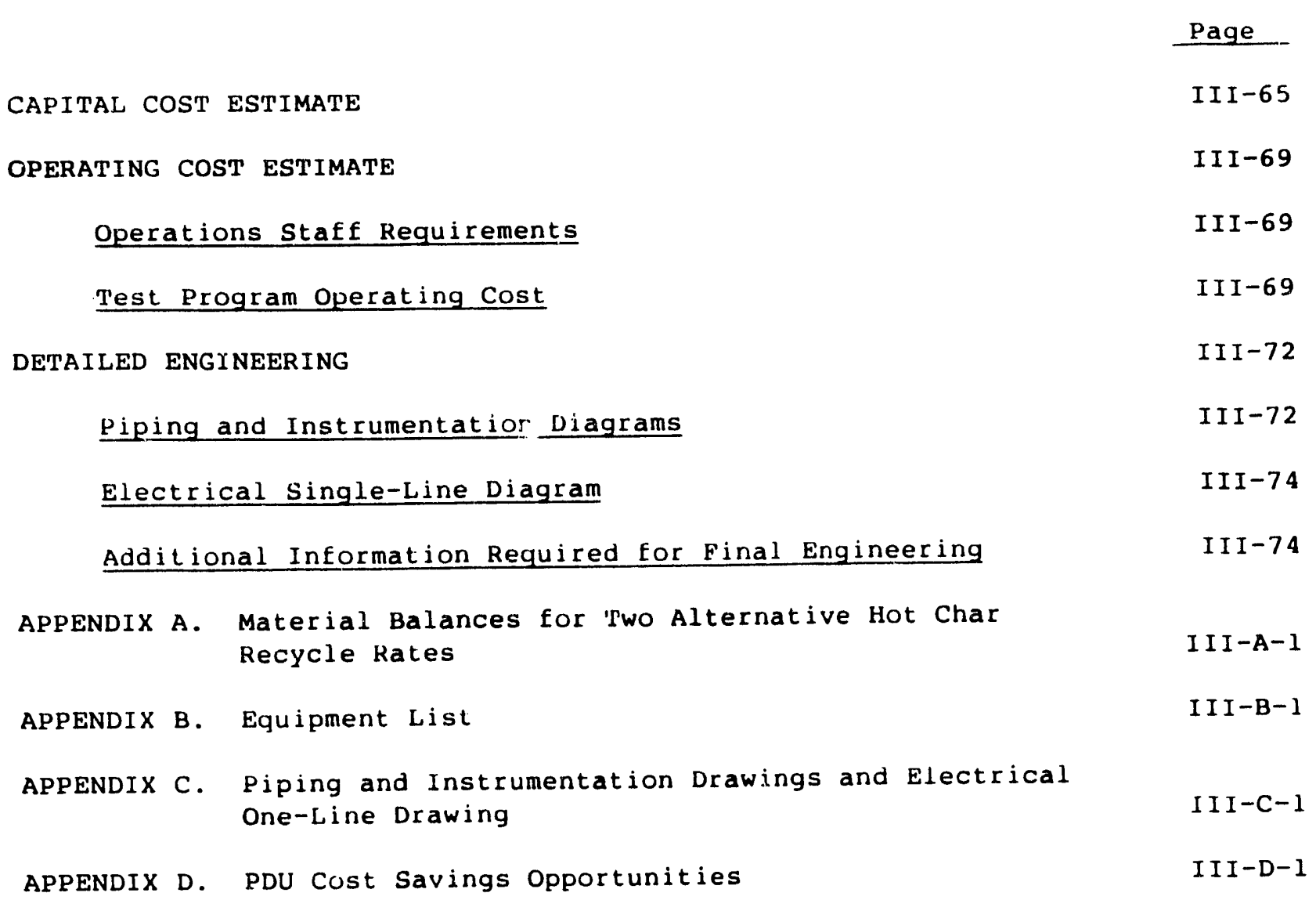


Figure No.

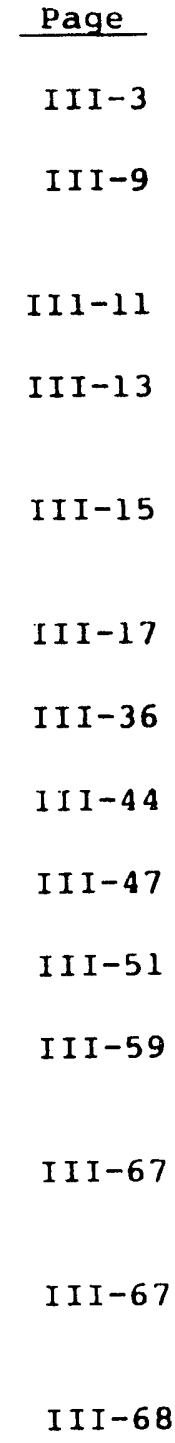

III-14 PDU Equipment Elevations Relative to the Existing High Bay Building

Mild Gasification Overall Block Diagram

III-2 Process Flow Diagram Coal Feed and Drying Unit

Process Flow Diagram Gasification and Heat Supply system

I I I -4

Process Flow Diagram Liquids Recovery System

Process Flow Diagram Char Storage/Handling

and Emission Control System

Process Flow Diagram Liquids Storage and Handling System

III-7 Mild Gasification Control Diagram

Mild Gasification Vessel -- 24 tpd PDU

III-9 Form Coke Production Block Diagram

I I I -10

Process Flow Diagram Form Coke Production

I I I -68 
Table No.

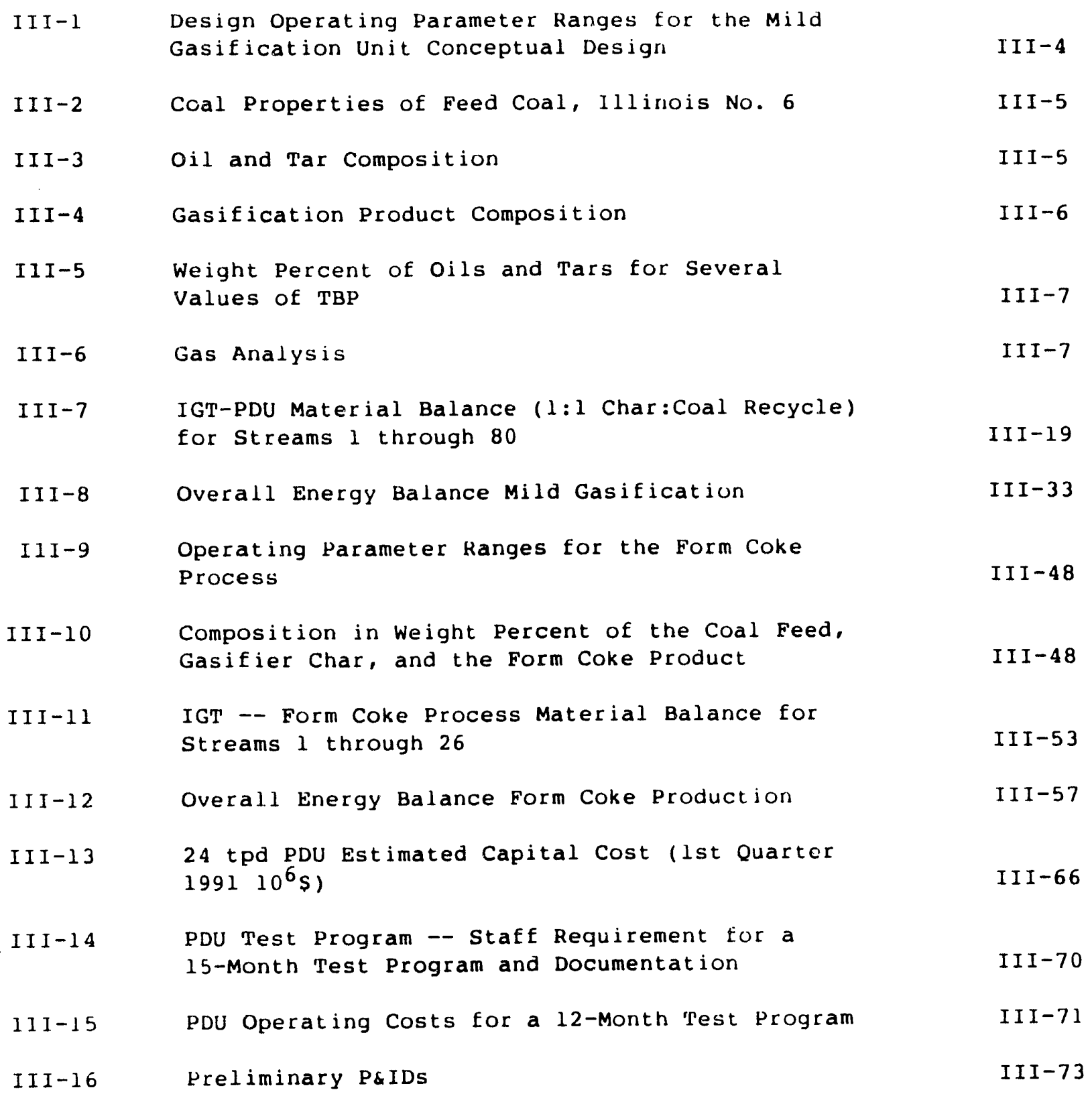




\section{INTRODUCTION}

The focus of this task is the preparation of (1) preliminary piping and instrument diagrams (P\&IDS) and single line electrical diagrams for a sitespecific conceptual design and (2) a factored cost estimate for a 24 ton/day (tpd) capacity mild gasification process development unit (PDU) and an associated form coke preparation PDU. The intended site for this facility is the Illinois Coal Development Park at Carterville, Illinois, which is operated by Southern Illinois University at Carbondale.

The basis for the PDU process design was derived from operating data obtained from the $100 \mathrm{lb} / \mathrm{hr}$ capacity process research unit (PRU) operated by IGT at its Energy Development Center in Chicago. The form coke facility configuration is based on the recommendations of IGT and its consultants. The conceptual-level cost estimate was developed from equipment costs and installation factors derived largely from Bechtel in-house data. 
MILD GASIFICATION UNIT CONCEPTUAL DESIGN

\section{Design Basis}

An overall block diagram for the continuous mild gasification process development unit (PDU) is shown in Figure III-1.

The mild gasification process selected is an advanced fluidized bed concept for low-temperature carbonization of coal. Gasification is carried out at temperatures of $1000^{\circ} \mathrm{F}$ to $1500^{\circ} \mathrm{F}$ and pressures of 0 to $50 \mathrm{psig}$ to convert crushed coal (or coal fines) to char and coal-derived liquids.

The design coal feed, which consists of wet -6 mesh $x$ fines from a coal cleaning plant, is first dried and preheated and then fed directly to the fluidized bed of the gasifier vessel. The fluidized bed is heated to $1200^{\circ} \mathrm{F}$ and fluidized by a recycle gas stream which has been heated to $2000^{\circ} \mathrm{F}$ to $2500^{\circ} \mathrm{F}$. Heat to the gasifier is supplied via a combination of hot char and hot gas recycle. Hot recycle char is supplied by partial combustion of a portion of the fluidized bed char. Hot recycle gas is produced by partial combustion of the noncondensable gas from liquids recovery. The unit is designed to permit the relative amounts of heat supplied by hot char and hot gas recycle to be varied. A greater hot char recycle rate results in less nitrogen dilution and a higher heating value of the noncondensable gas.

The design includes optional thermal cracking of the product vapor at temperatures up to $1,800^{\circ} \mathrm{F}$ before condensation. The retort product vapor is processed in conventional cyclones to remove entrained char fines. In the condensation step, product vapor is cooled and compressed to recover tar, middle oil, light oil, and water. The noncondensable gas is either recycled to the gasifier or incinerated. The coarse char is removed from the fluidized bed. Both the char fines and coarse char streams are cooled for storage and/or sutsequent briquetting.

Gas streams exiting from the char heater, coal dryer, and liquids recovery section are incinerated and subsequently scrubbed to control sulfur emissions. In addition, the small quantity of sour water from liquids recovery may also be incinerated. Heat recovered from the incinerator flue gas is used to preheat both recycle gas for gasifier fluidization and clean flue gas for coal drying/preheating. 


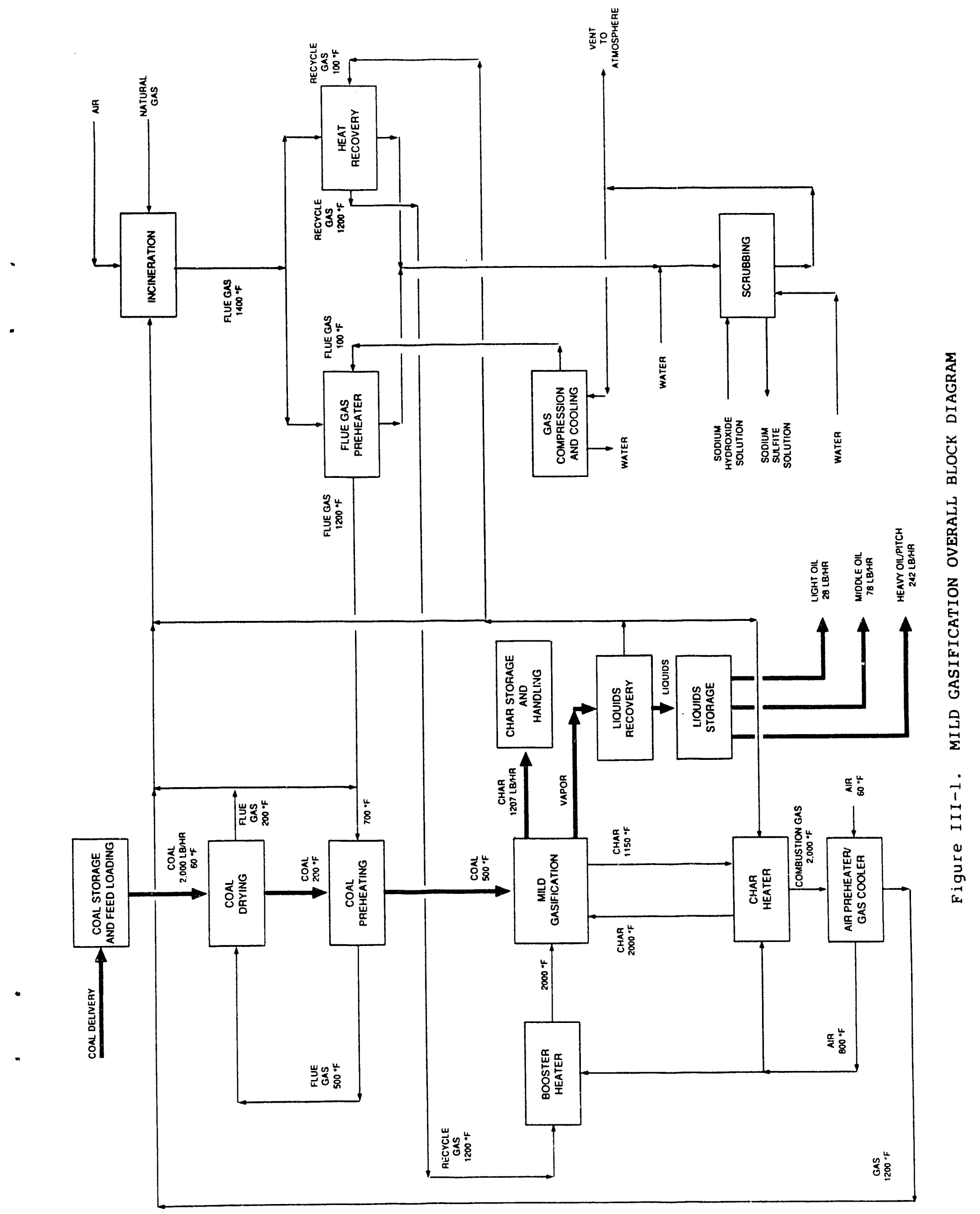




\section{System Capacity}

The normal capacity of the mild gasification unit has been opecified as 24 tpa of moisture-free coal (Illinois No. 6). This capacity of the process system and corresponding design of the equipment is selected to:

- Provide an adequate scale for equipment and process demonstration and to develop an adequate basis for the design of a commercial-scale facility

- Maintain a manageable and cost-effective scale for establishing design parameters and for product property and use testing

\section{Design Operating Parameters}

The ranges of the design operating parameters have been selected by IGT for the test operation. These parameters, along with their maximum, nominal, and minimum values, are 1 isted in Table III- 1 .

Table III-1. DESIGN OPERATING PARAMETER RANGES FOR THE MILD GASIFICATION PDU

\begin{tabular}{|c|c|c|c|}
\hline Parameter & Maximum & Nominal & Minimum \\
\hline Operating Pressure, psia & 50.0 & 30.0 & 12.0 \\
\hline \multicolumn{4}{|l|}{ Operating Temperature, ${ }^{\circ} \mathrm{F}$} \\
\hline Fluidized Bed & 1300 & 1100 & 1000 \\
\hline Entrained Bed (In) & 1300 & 1100 & 1000 \\
\hline Entrained Bed (Out) & 1300 & 1000 & 900 \\
\hline \multicolumn{4}{|l|}{ Gas Velocities, ft/sec } \\
\hline Eluidized Bed Inlel & 9.0 & 8.0 & 6.0 \\
\hline Fluidized Bed & 4.5 & 4.0 & 3.5 \\
\hline Entrained Bed & 16.0 & 14.2 & 12.0 \\
\hline \multicolumn{4}{|l|}{$L / D$ Ratio } \\
\hline Fluidized Bed Inlel & $\mathrm{N} / \mathrm{A}$ & 1 & $\mathbf{N} / \mathbf{A}$ \\
\hline Fluidized Bed & 2 & 1 & 0.5 \\
\hline Entrained Bed & -- & 16 & -- \\
\hline \multicolumn{4}{|l|}{ Bed Residence Time } \\
\hline Fluidized Bed (min) & 14.8 & 6.3 & 2.5 \\
\hline Entrained Bed (sec) & 1.3 & 1.1 & 1.0 \\
\hline \multicolumn{4}{|l|}{ Hot Char Recycle $(60+$ mesh) } \\
\hline Char/Coal Ratio & 2 & 1 & 0 \\
\hline Temperature, ${ }^{\circ} \mathrm{F}$ & 2200 & 1800 & 1400 \\
\hline \multicolumn{4}{|l|}{ Hot Gas Recycle } \\
\hline Gas Temperature, ${ }^{\circ} \mathrm{F}$ & 2500 & 2000 & 1500 \\
\hline Coal Feed (MF) Basis & & & \\
\hline Fluidized Bed $(+100$ mesh $)$ & $1600 \mathrm{lb} / \mathrm{hr}$ & & \\
\hline Entrained Bed $(100$ mesh $\times 0)$ & $4001 \mathrm{~b} / \mathrm{hr}$ & & \\
\hline
\end{tabular}




\section{Yields and Compositions}

An illustrative yield structure for mild gasification was derived from IGT's process research unit (PRU) Run MG-12. Gas and liquid compositions were obtained directly from run data for MG-12. The product yields were adjusted . to give a conservative estimate of valuable product yields based on data accumulated for several runs. Run MG-12 employed a sample of Illinois No. 6 coal fines provided by Peabody Coal Company. The coal properties and the measured yields of char, and net volatile products are summarized in Table III-2. The bulk elemental analysis of oils and tars were assumed to be $\therefore$ as shown in Table III-3.

Table III-2. COAL PROPERTIES OF FEED COAL, ILLINOIS NO. 6

$\begin{array}{lr}\text { Item } & \text { Wt } z \\ \begin{array}{c}\text { Proximate Analysis } \\ \text { Moisture }\end{array} & 3.32 \\ \text { Volatile } & 35.23 \\ \text { Fixed Carbon } & 47.34 \\ \text { Ash } & \frac{14.11}{00.00} \\ \text { Total } & 11.520 \\ \text { Ultimate Analysis } & \\ \text { Carbon } & 65.43 \\ \text { Hydrogen } & 4.43 \\ \text { Oxygen } & 10.49 \\ \text { Nitrogen } & 1.28 \\ \text { Sulfur } & 3.81 \\ \text { Ash } & 14.56 \\ \text { Total } & 100.00 \\ \text { HHV } 11,520 \text { Btu/1b } & \\ \text { Overall Yields } & \\ \text { Char } & 66.6 \\ \text { Oils and Tars } & 18.3 \\ \text { Gas } & 10.3 \\ \text { Water } & 4.8 \\ \text { Total } & 100.00\end{array}$

Table III-3. OIL AND TAR COMPOSITION

\begin{tabular}{|c|c|}
\hline \multicolumn{2}{|r|}{ Wt 8} \\
\hline Carbon & 74.24 \\
\hline Hydrogen & 6.74 \\
\hline Oxygen & 16.22 \\
\hline Nitrogen & 0.78 \\
\hline Sulfur & 1.61 \\
\hline Ash & 0.42 \\
\hline Total & 100.00 \\
\hline
\end{tabular}


The component analyses of the full-range oils and tars are expanded into the following four fractions expressed as weight percent of the total oils and tars.

Table III-4. GASIFICATION PRODUCT COMPOSITION

\begin{tabular}{lc}
\multicolumn{1}{c}{ Item } & Wt 8 \\
\cline { 2 - 2 } Light oil product & \\
Benzene & 1.2 \\
Toluene & 1.3 \\
Xylenes & 0.8 \\
Ethylbenzene & 0.6 \\
Indene & 0.4 \\
Styrene & 0.3 \\
Other light oils & $\frac{4.3}{8.9^{\mathrm{a}}}$ \\
Total light oil & \\
Middle oil product & 1.0 \\
Phenols & 1.4 \\
Cresols & 0.6 \\
Xylenols & 0.5 \\
Naphthalene & $\frac{11.8}{15.3^{b}}$ \\
Other middle oils & \\
Total middle oils & $11.7^{\mathrm{C}}$ \\
Heavy oil product & $64.1^{\mathrm{d}}$ \\
Heavy oil & 100.00 \\
Pitch &
\end{tabular}

a Atmospheric boiling point less than $360^{\circ} \mathrm{F}$.

b Atmospheric boiling point $360^{\circ} \mathrm{F}$ to $590^{\circ} \mathrm{F}$.

C Atmospheric boiling point $590^{\circ} \mathrm{F}$ to $750^{\circ} \mathrm{F}$.

d Atmospheric boiling puint greater than $750^{\circ} \mathrm{F}$.

For more precise modeling of the performance of the condensing train, the IGT-simulated distillation curves for the heavy oil and pitch were used to develop the petroleum-type true boiling point (TBP) distribution breakdown for the combined heavy oil and pitch fraction as shown in Table III-5.

The net makeup of noncondensable gas from mild gasification has the estimated volumetric composition (expressed as mols) given in Table III-6.

\section{Process Description}

The proposed process flow scheme for the 24 tpd mild gasification process is divided into the following five major sections: 
- Coal feed and drying

- Gasification and heat supply

- Liquids recovery system

- Emission control and char handling

- Liquids storage and handling

Table III-5. WEIGHT PERCENT OF OILS AND TARS FOR SEVERAL VALUES OF TBP

TBP $\left({ }^{\circ} \mathrm{F}\right)$

333
438
544
649
754
860
965
1070
1176
1281
1386
1492
1597

1597

Total
Wt 8

2.0

2.1

2.5

2.5

2.6

6.2

5.3

5.7

5.9

6.0

6.1

6.3

22.6

Table III-6. GAS ANALYSIS

Molz in Gas,

Component

Hydrogen

Carbon Monoxide

Carbon Dioxide

Methane

Ethylene

Ethane

Propylene

Propane

Hydrogen Sulfide

Total.

\section{Nitrogen Free}

$$
\begin{array}{r}
37.5 \\
16.1 \\
8.7 \\
23.3 \\
6.3 \\
2.5 \\
2.1 \\
0.2 \\
3.3 \\
\hline 100.0
\end{array}
$$

Each section is described below with reference to its specific process flow diagrams (Figures III-2 through III-6). A base case material balance keyed to the flow diagrams and based on a hot recycle char to coal ratio of $1: 1$ is included as "mble III-7 following Figure III-6. Two additional balances differing in the quantity of hot char recycle employed for gasification heat input have also been developed. 


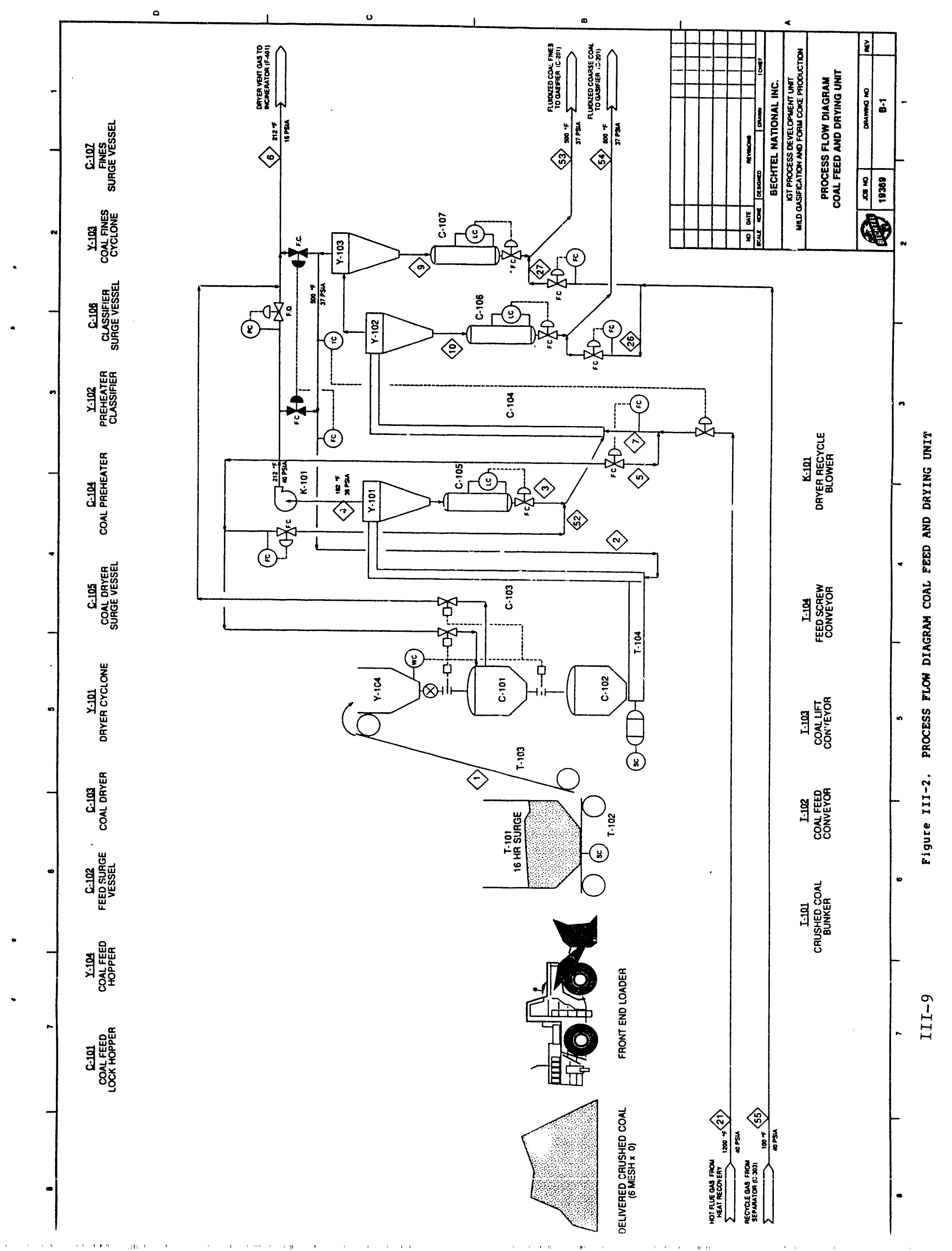




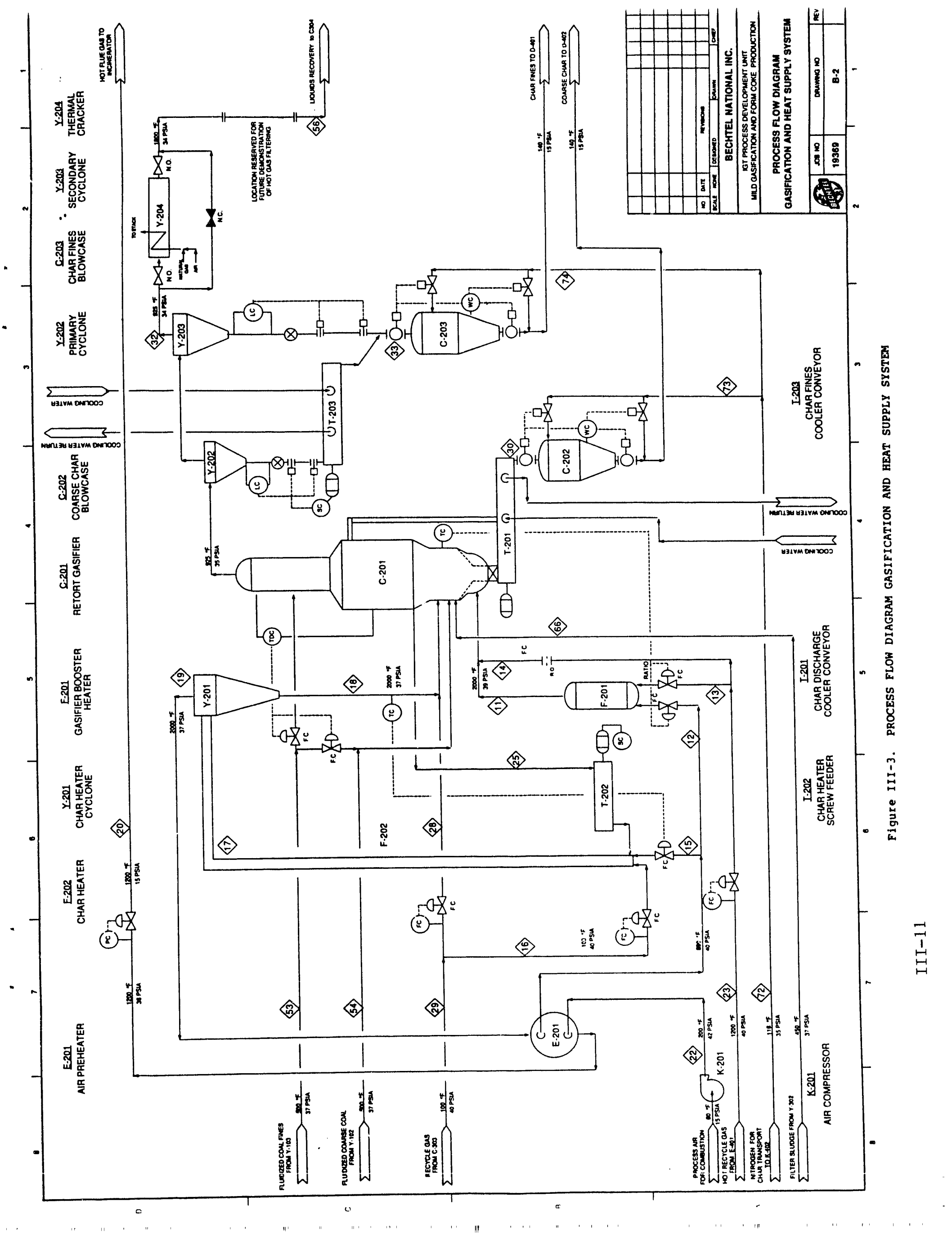




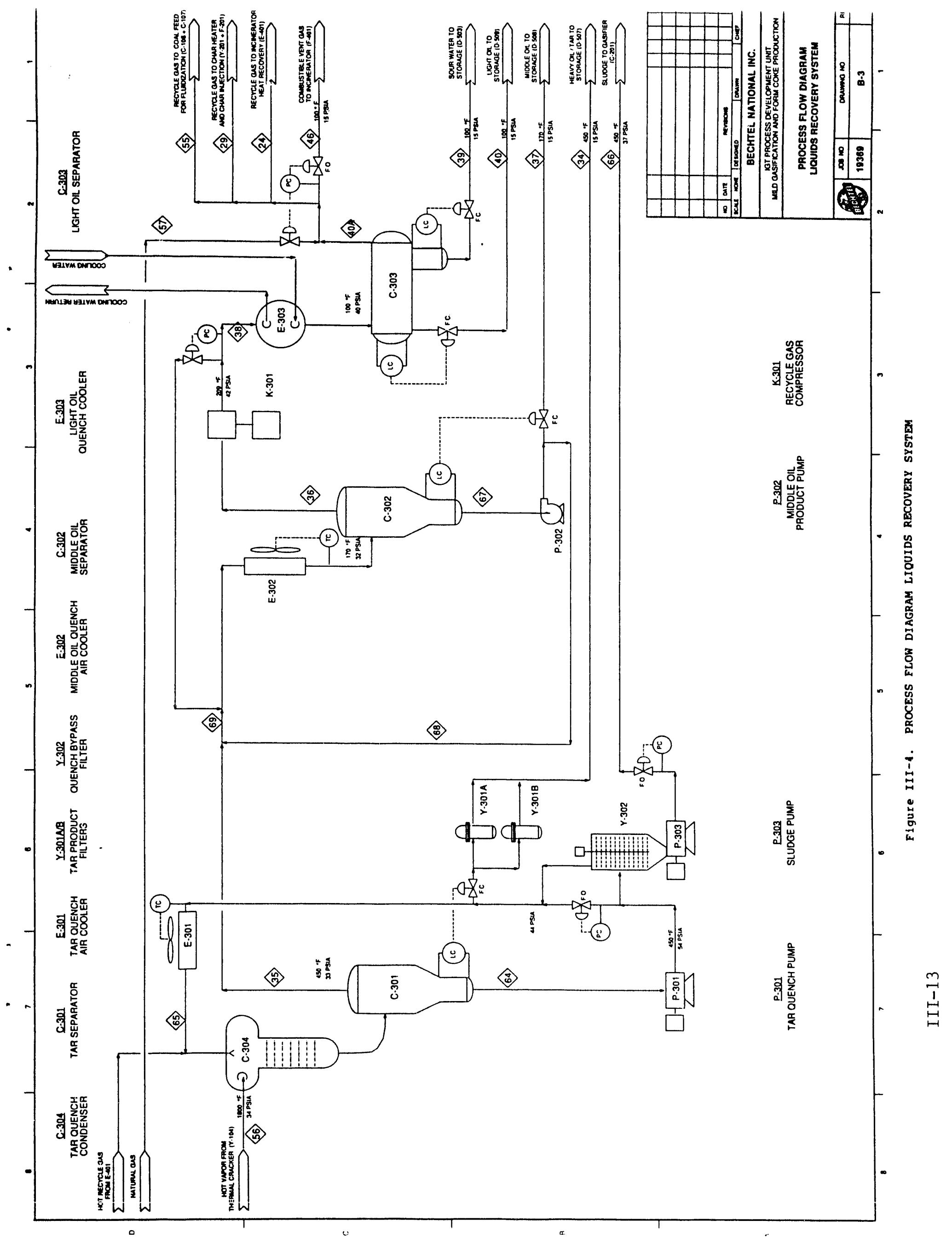




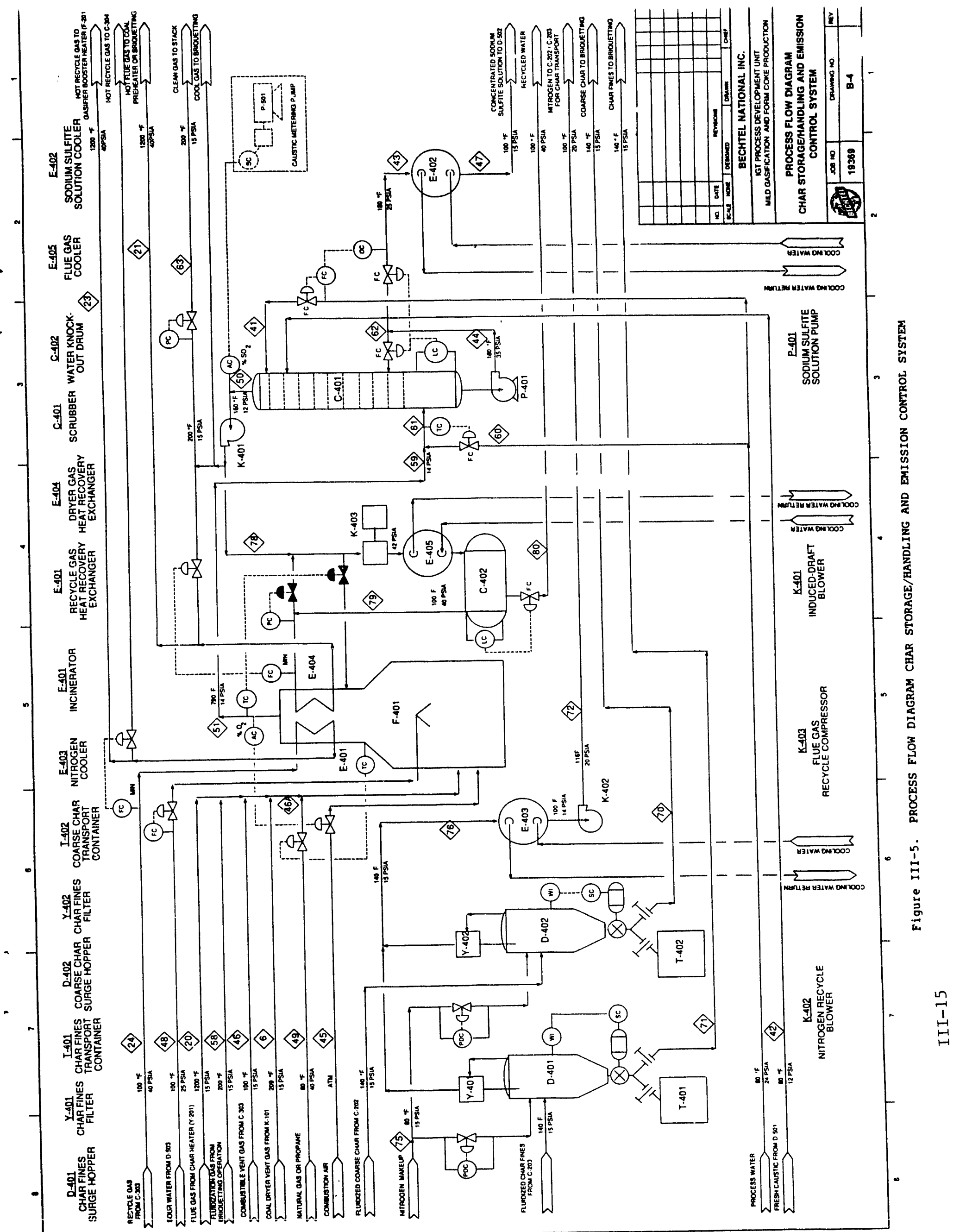




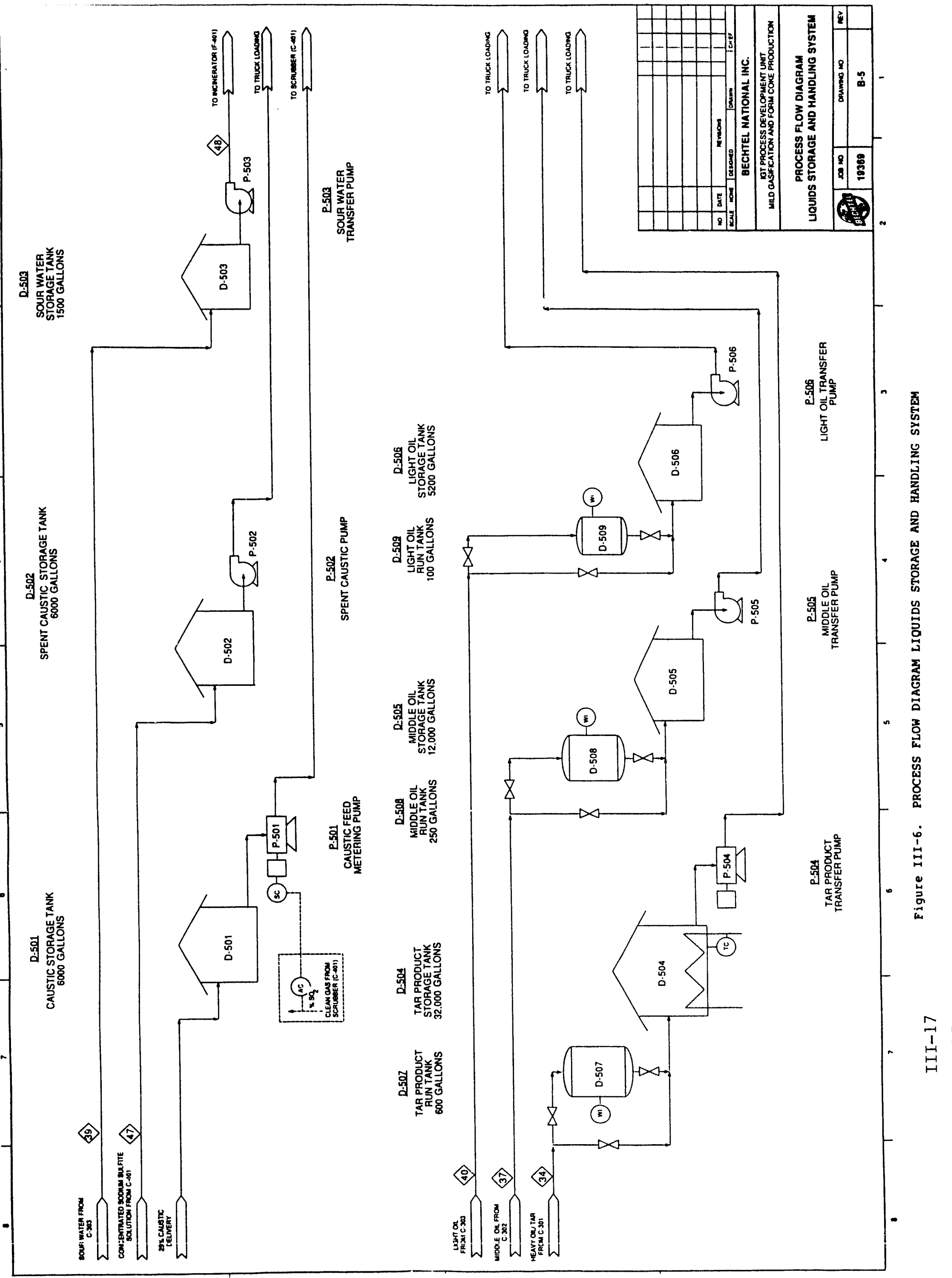




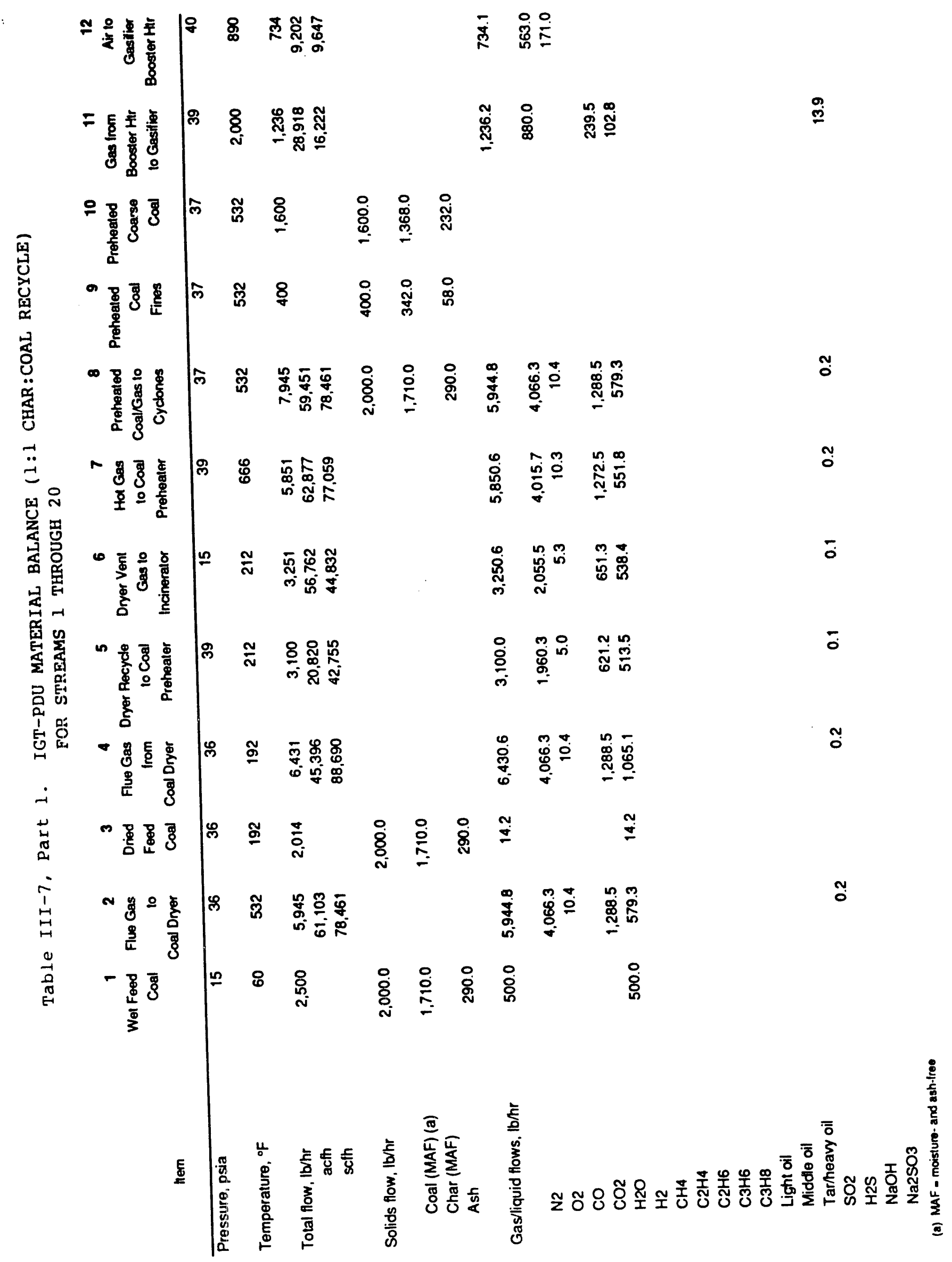




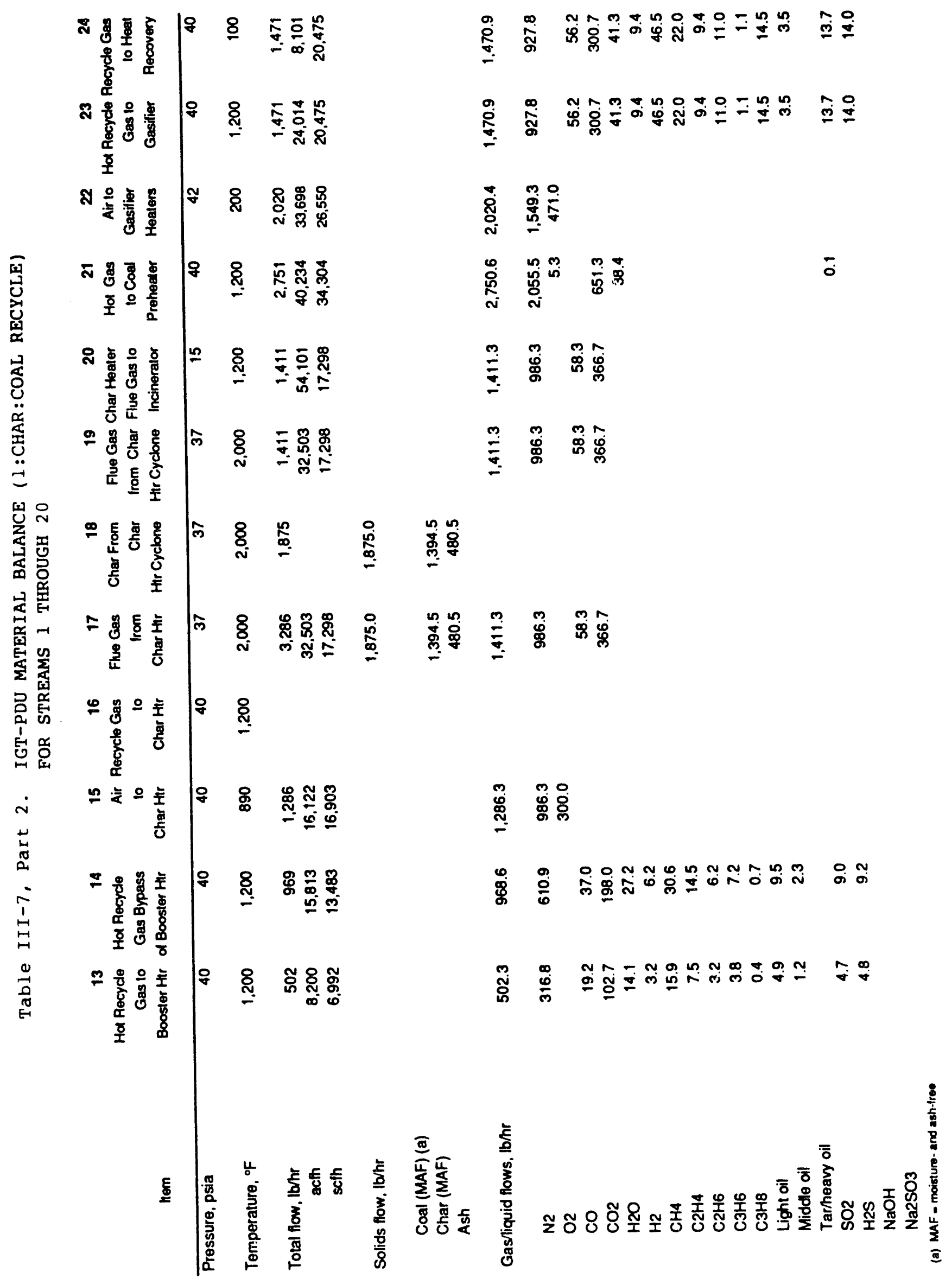




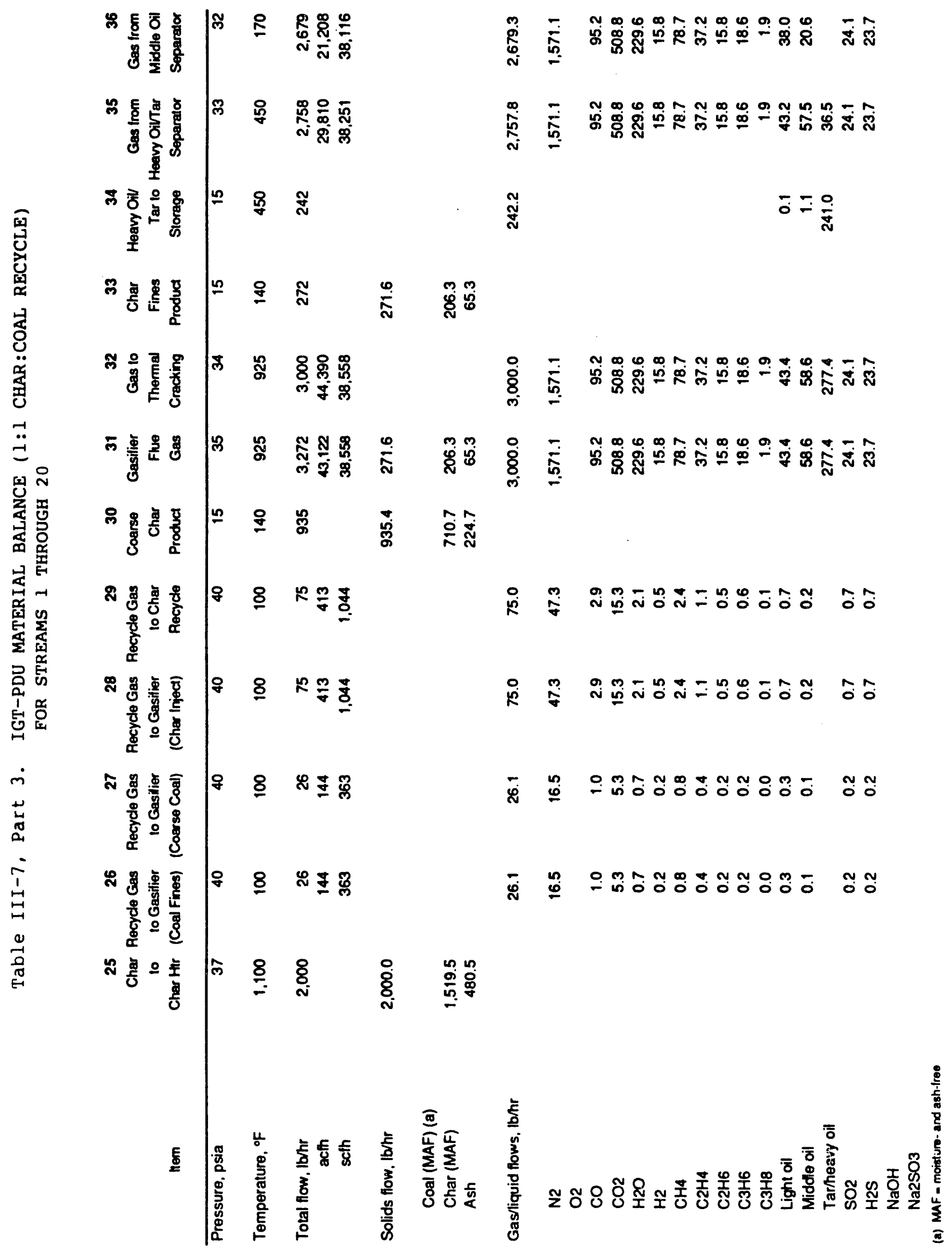




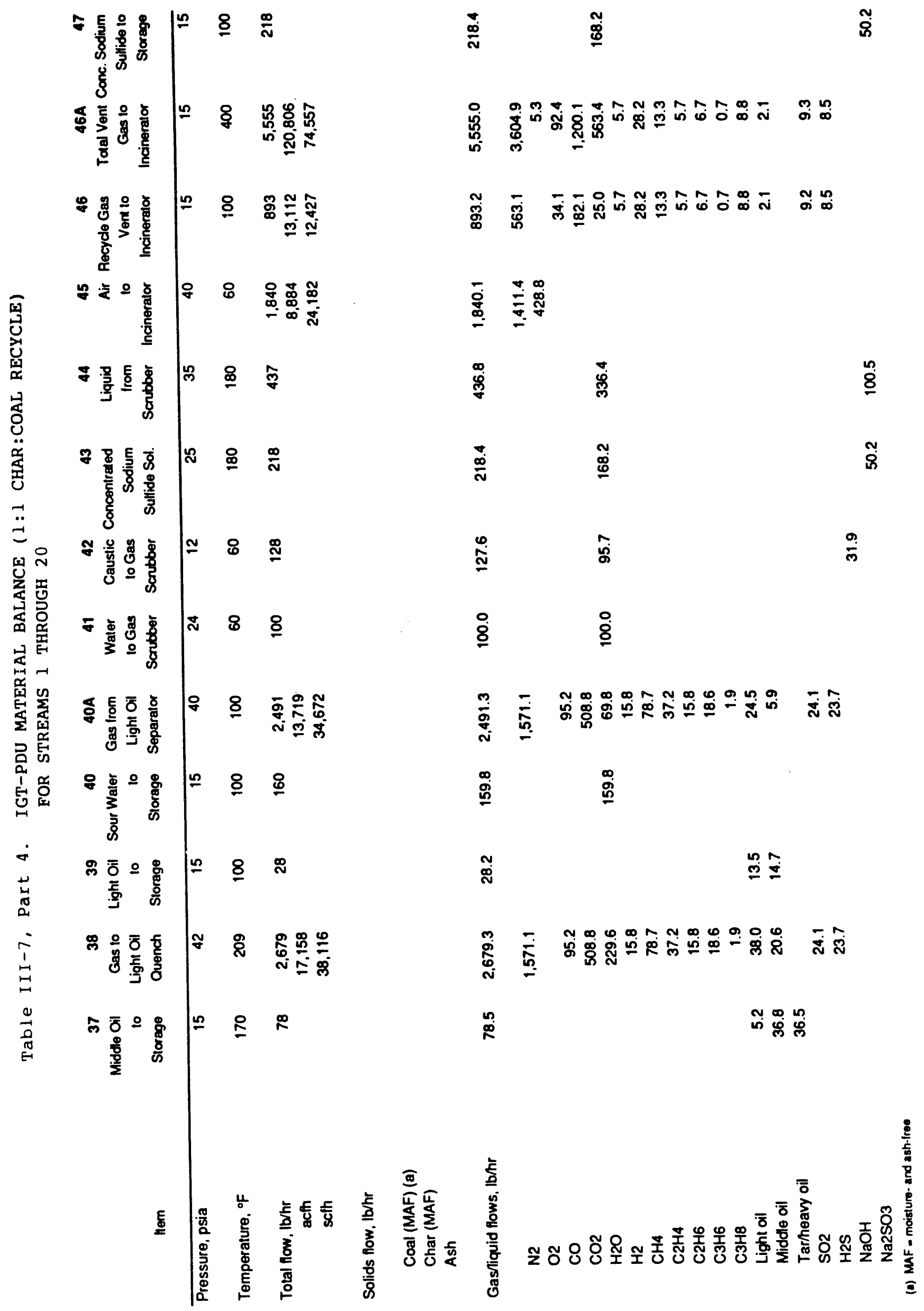




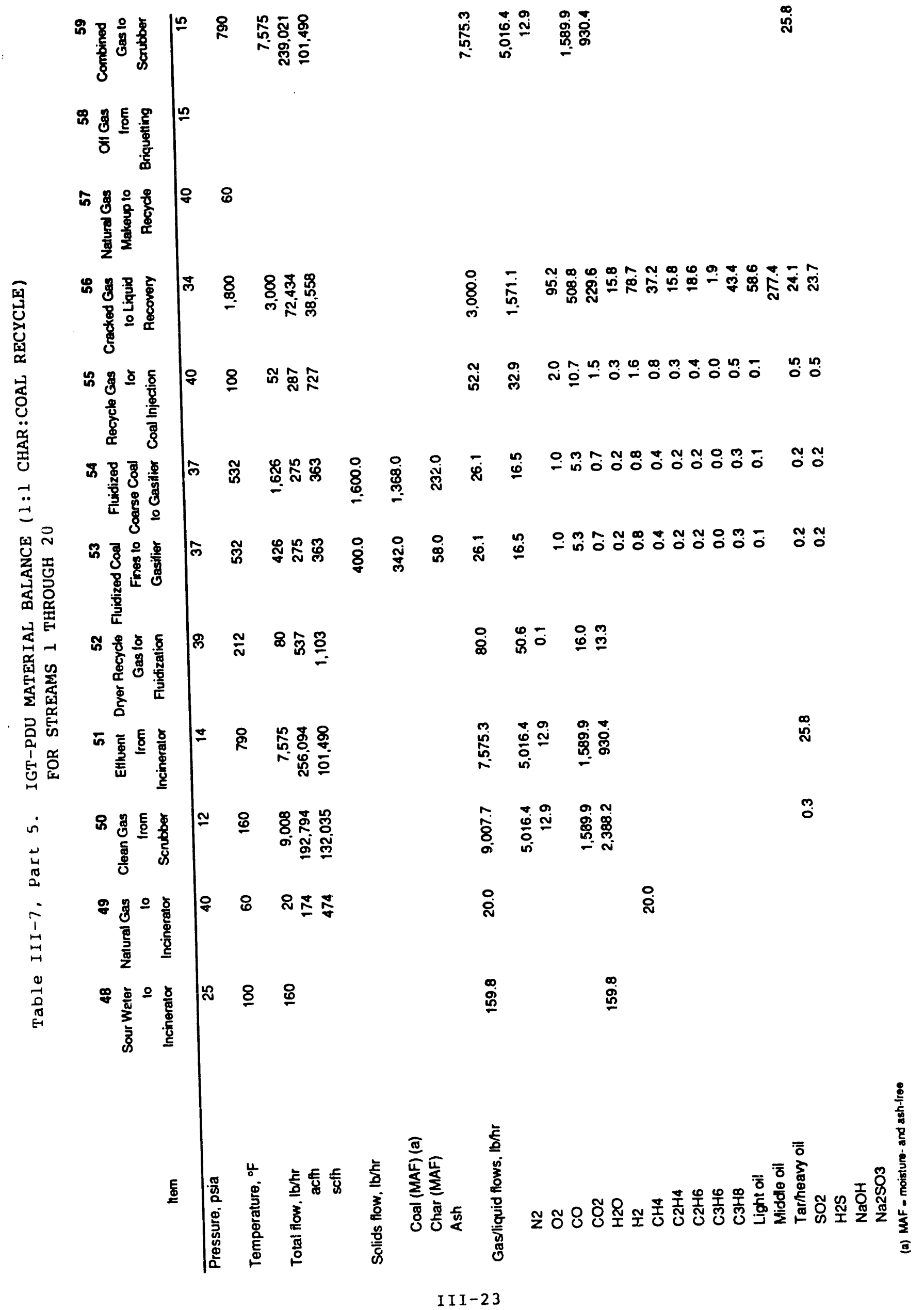




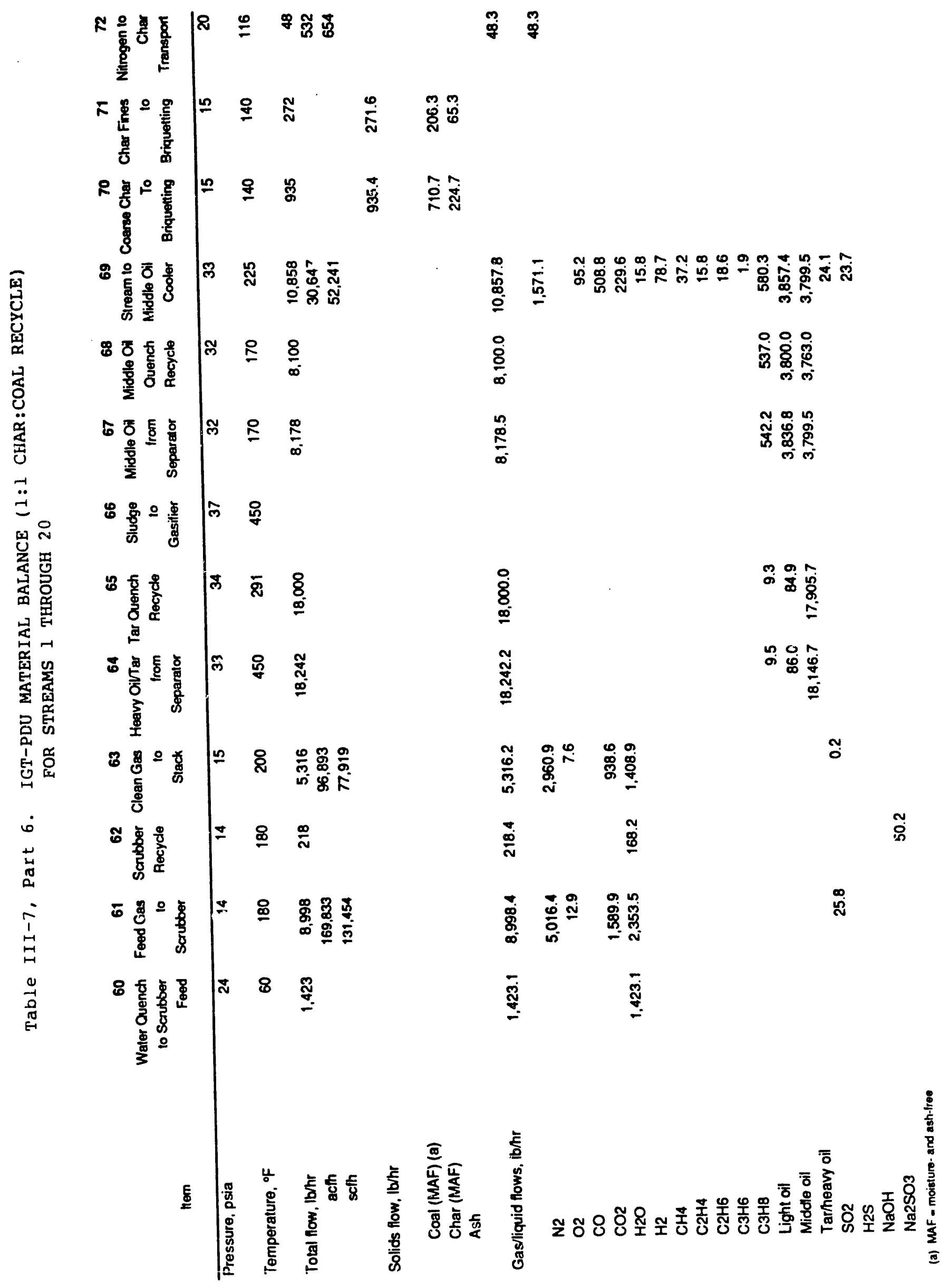




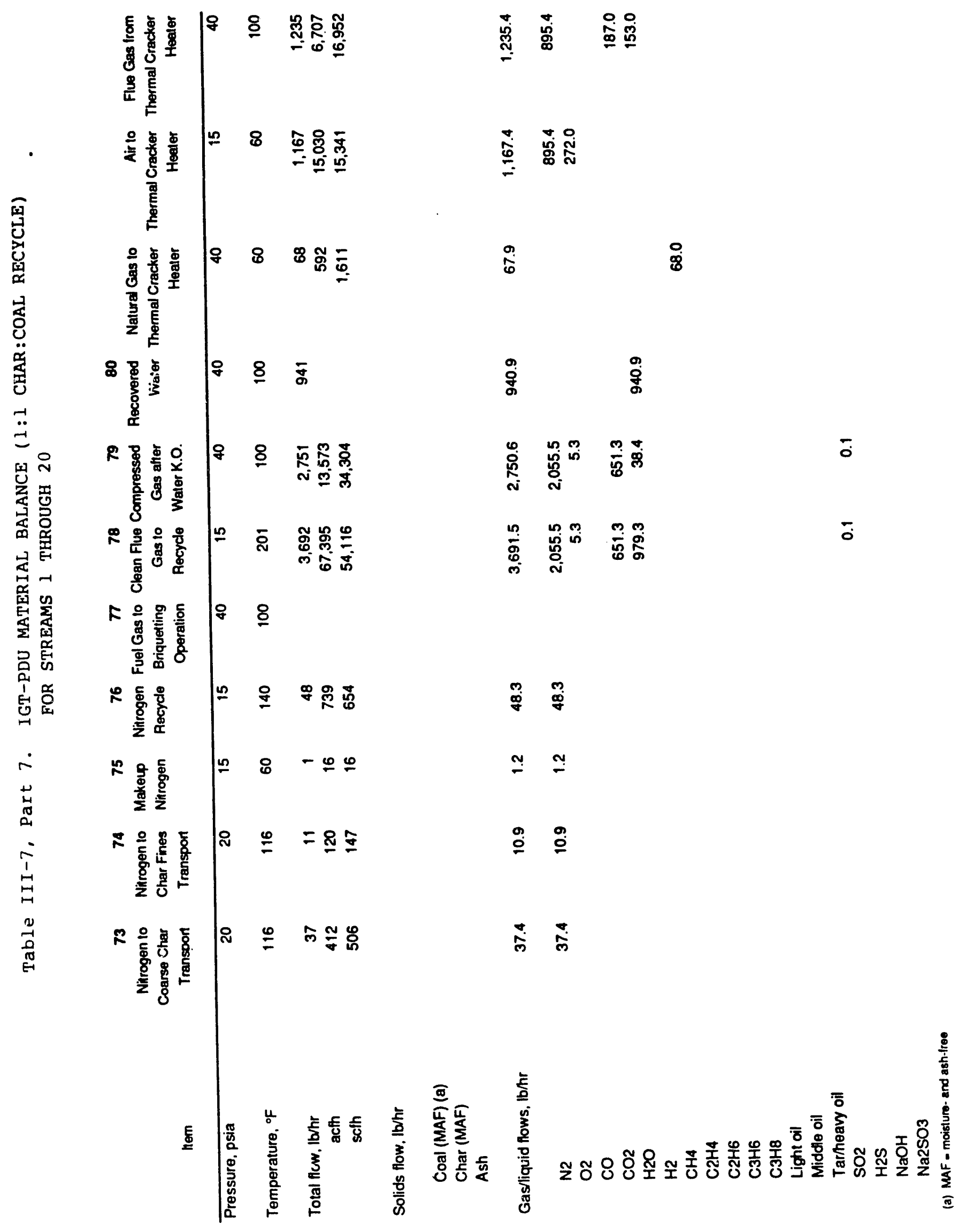


These balances, based on 0.5 and 2 tons of hot char recycle/ton of dry coal feed, are included for reference in Appendix $A$. The temperatures shown in the flow diagrams are nominal values used for equipment specification and differ in some instances from those determined for the three illustrative material balances.

\section{Coal Feed and Drying}

The coal feed and drying unit is shown on Figure III-2 and described below.

\section{Coal supply}

The wet coal feed, which consists of -6 mesh $x 0$ fines from a coal cleaning plant, is received by truck and dumped into a storage pile. Coal from this pile is transferred by a front-end loader to the crushed coal bunker (T-101), which has a capacity of 16 tons. Coal is fed by a belt feeder $(T-102)$ and a lift belt $(T-103)$, which intermittently delivers coal to the coal feed hopper $(Y-104)$. From this hopper, a preset charge of coal is added to the feed lock hopper $(C-101)$. The lock hopper in turn discharges to a coal surge vessel (c-102), from which the coal is fed to the coal dryer by a screw conveyor $(\mathrm{T}-104)$.

The coal feed rate is set by the variable speed screw conveyor. The conveyor speed is adjusted automatically based on the lock hopper cycle time whose dump cycle is controlled by low level in the coal surge vessel. The coal feed hopper is mounted on weigh cells to permit accurate metering of coal into the unit.

\section{Coal Drying, preheating, and Fines separation}

The coal feed is first dried and then preheated in two entrained-flow vertical lift-pipes $(\mathrm{C}-103$ and $\mathrm{C}-104)$. The heating medium is scrubbed flue gas reheated by heat recovery with incinerator offgas. The flue gas supplied to the coal preheater is maintained below 5 volis oxygen content, and its temperature entering the coal preheater is limited to $700^{\circ} \mathrm{F}$ by recycle of cool wet gas from the dryer exit. Independent temperature and fluidization control is provided for the dryer and preheater through appropriate bypass $I$ ines.

In operation, the unit coal feed is elevated and dried in the dryer Iift pipe (C-103) by hot gas exiting the coal fines cyclone $(Y-103)$. The dried 
coal is separated from the wet flue gas in the dryer cyclone $(Y-101)$ and moved via dense-phase fluidization to the coal preheater lift pipe (C-104). A surge vessel (C-105) is provided to minimize process upsets and to maintain a seal leg of solids between the dryer cyclone and preheater.

The dried coal is elevated and preheated by a stream of hot flue gas. The coarse fraction of the preheated coal is recovered by the preheater classifier $(Y-102)$. Flue gas and fines from the classifier are separated in the coal $f$ ines cyclone $(Y-103)$. Coarse coal and coal fines are collected in the classifier surge vessel $(C-106)$ and the fines surge vessel (C-107), respectively, then conveyed to the gasifier via dense-phase fluidization using recycle gas from liquids recovery.

\section{Gasification and Heat Supply}

The gasification and heat supply is shown on Figure III-3 and described below.

\section{Mild Gasificalion}

The preheated $\left(500^{\circ} \mathrm{F}\right.$ ) coarse coal (about 808 of the total coal feed) is fed to the fluidized bed (lower) section of the mild gasification vessel (C-201). The coal fines (remaining 208) are fed separately to the entrained bed (upper) section of the vessel. The fluidized bed is heated to the gasification temperature of $1000^{\circ} \mathrm{F}$ to $1200^{\circ} \mathrm{F}$ and fluidized by an inlet gas stream which has been heated to $2000^{\circ} \mathrm{F}$ to $2500^{\circ} \mathrm{F}$.

The finest fraction ( -60 mesh) of the coarse coal feed tends to separate from the fluidized bed and, together with the fine coal feed, is carried upward through the entrained flow section of the vessel. This section is sized to provide adequate time for gasification of the entrained fines before they separate from the hot gas and product vapors in the two exit cyclones $(Y-202$ and $Y-203)$.

The net production of coarse char is removed from the fluidized bed by overflow into a short-residence-time standpipe. From there, the char is removed and cooled by intermittent operation of the char discharge cooler conveyor ( $T-201)$. This conveyor operates as needed to fill the coarse char blow case (C-202) from which the char is intermittently transferred via densephase fluidization to storage using a closed-loop recycled nitrogen stream. 
The bulk of the char fines from the char fines primary cyclone is similarly cooled and discharged from the cyclone dipleg by the char fines cooler conveyor (T-203). This char and the small quantity of fines - accumulated from the secondary cycione are combined into the char fines blowcase (C-203), from which char fines are intermittently transferred to storage via dense-phase fluidization with recycled nitrogen.

\section{Heat Supply}

Recycle Gas Heating. Recycle gas from the liquids recovery section provides a combustible fuel for heat input as well as a gas flow to heat and fluidize the gasifier. Hot recycle gas $\left(2000^{\circ} \mathrm{F}\right.$ to $\left.2500^{\circ} \mathrm{F}\right)$ is produced by (1) preheating the gas by heat exchange with incinerator offgas, (2) boosting its temperature by combusting a portion of the recycle gas with air in the booster heater $(F-201)$, and (3) combining the combustion products with the remaining (uncombusted) recycle gas. Partial combustion of the entire recycle gas stream is less desirable since oxygen-deficient combustion is likely to produce unwanted products (e.g., aldehydes).

Char Heating. To reduce heating gas requirements for the mild gasification, provision is made to supply a portion of the gasifier heat input by hot char recycle. Char is withdrawn from the fluidized bed by a screw conveyor (T-202) and fed at a controlled rate to a char heater lift pipe (F202). The char is elevated and heated by partial combustion (gasification) with air. The heated char at an exit temperature of $1800^{\circ} \mathrm{F}$ to $2000^{\circ} \mathrm{F}$ is separated from the gas by the char heater cyclone $(Y-201)$ and returned to the gasifier. The gas leaving the char heat cyclone is combustible (low-Btu gas) and contains char fines. A portion of the heat from this hot flue gas is recovered in the air preheater (E-201), which serves to preheat combustion air for the char heater and gasifier booster heater.

\section{Thermal Cracking}

Thermal cracking has been proposed as a means of improving the properties of recovered tar products produced by mild gasification. The design includes a thermal cracker (Y-204) capable of operating at temperatures up to $1800^{\circ} \mathrm{F}$. Flue gas exiting the secondary cyclone is thermally cracked before being sent to liquids recovery. An appropriate bypass line permits direct flow from the secondary cyclone to liquids recovery without thermal cracking. 


\section{Optional Hot Gas Filtering}

The proposed unit has been designed to accommodate small amounts of char fines to be entrained into the liquids recovery section. In a large-scale commercial operation, hot gas filtering may prove to be an economical means of fines removal. Filters for this type of application are now being developed under sponsorship of the U.S. Department of Energy's Morgantown Energy Technology Center. The PDU may provide a means of evaluating this developing technology by filtering a slip stream of hot gas.

\section{Liquids Recovery system}

The liquids recovery system is shown in Figure III-4 and described below. The liquids recovery train condenses three boiling ranges of products by cooling the gas stream to successively lower temperatures.

\section{Tar Recovery}

The first high-temperature tar condensation is carried out by contacting the gas stream with a cooled tar quench stream. The temperature is controlled to the maximum that will yield a fluid condensate of heavy tar and pitch. The initial condensation is carried out in a wetted wall quench condenser (C-304), selected to minimize fouling which might be produced at the point of initial condensation of the highest boiling point tars (aggravated by the possible presence of char fines). A wall scraper may also be needed at the hot-cold interface at the inlet to the quench. The recycled tar is cooled in the tar quench air cooler $(\mathrm{E}-301)$.

The tar condensate and vapors are separated in the tar separator (C-301). The tar quench is recycled by means of the tar quench recycle pump (P-301). The recycled tar is filtered by the quench bypass filter (Y-302) to prevent accumulation of entrained char $f$ ines in the recycled tar quench stream. A continuous cleaning edge-type filter is proposed for this application with intermittent blowdown for sludge removal. A sludge pump (P-303) provides a means for disposal of the sludge by recyling the accumulated material back to the gasifier. Tar product filters $(Y-401$ A/B) are included for trace solids removal from the net condensed tar. 


\section{Middle Oil Recovery}

The second-stage condensation is carried out at a temperature just above the temperature at which the water condenses. This is done in order to avoid the formation of difficult-to-separate water in oil emulsion and results in recovery of a dry middle oil fraction. The vapors from the tar separator are cooled by the middle oil quench air cooler (E-302), and the condensed liquids are separated in the midale oil separator $(C-302)$. The middle oil quench pump $(P-302)$ causes oil to recikculate through the air cooler to prevent the accumulation of condensed tars on heat transfer surfaces.

\section{Light Oil Recovery:}

The vapors and gases from the second stage are compressed slightly to furnish the necessary pressure for gas recycle and then cooled with cooling water (E-303). Condensed 1 ight oil and water are recovered and separated in the light oil separator (c-303). Because of the large flow of recycle gas, hydrocarbons lighter than benzene are not recovered in substantial quantity. Yields of uncondensed products are determined through gas analysis and flow measurements. The recovered 1 ight oil and sour water are discharged to their respective storage tanks.

\section{Emission Control and Char Handling}

The emission control and char handling system is shown in Figure III-5 and described below.

\section{Emission Control}

The incinerator $(\mathrm{F}-401)$ provides a means for total oxidation of all waste combustible gases and liquids, including their contained sulfur species. In addition, the incinerator is an integral part of the unit heat balance. Surplus recycle gas from the light oil condensation, together with the vent gases from the coal dryer and the char heater, is burned to convert the sulfur compounds (largely $\mathrm{H}_{2} \mathrm{~S}$ ) to $\mathrm{SO}_{2}$. Sour water from storage can also be injected into the incinerator to oxidize dissolved ammonia, phenols, and sulfur species. The hot incinerator off gases are contacted in a convective heat transfer zone to reheat recycle gas (E-401) to the gasifier and to reheat clean flue gas $(E-404)$ for heat supply for coal drying and preheating. 
After heat exchange, the incinerator flue gas is partially cooled by water injection and then contacted with caustic and water in the scrubber $(C-401)$. The spent caustic is discharged as a concentrated stream of sodium sulfite solution and transported offsite for disposal (or possible use). A pump ( $\mathrm{P}-401)$ serves to recirculate sodium sulfite solution within the lower section of the column and to transfer the net product to storage. Before being sent to storage, the sodium sulfite solution is cooled with water $(\mathrm{E}-402)$.

The scrubber and incinerator operate at slightly below atmospheric pressure, as maintained by the induced draft blower $(\mathrm{K}-10 \mathrm{l})$. The induceddraft blower discharges gas to the stack with a portion of the gas recycled for heat integration. The recycled flue gas is compressed (K-403) above the operating pressure of the coal preheater and water-cooled (E-405) to condense water. The condensed water is removed in the water knockout, drum (C-402). The flue gas is then reheated in a convective coil (E-40a) located in the incinerator discharge.

T'o prevent overheating of the furnace tubes, a minimum flow of flue gas is maintained through E-404. Excess preheated flue gas is spilled to the stack to reheat and minimize the amount of water from the vent gases. To protect the heat exchange surface from overheating, a minimum flow of recycle gas is maintained through E-404. The excess recycle gas is spilled back to the 1 iquids recovery section and is processed, along with the gasifier flue gas. This flow is normally zero.

\section{Char Handling}

The cooled coarse and fine char products from the gasification are pneumatically conveyed to their respective storage hoppers $(D-401$ and $D-402)$ using a closed-loop nitrogen recycle system. Fines are removed from the recycled nitrogen by gas filters $(Y-401$ and $Y-402)$. Recycled nitrogen is water-cooled $(E-403)$ and recirculated by the nitrogen recycle blower (k-402). To maintain atmospheric pressure, makeup nitrogen is added to the storage hoppers. The coarse and fine char products can be discharged from their respective hoppers into containers ( $\mathrm{T}-401$ and $\mathrm{T}-402)$ for offsite use or disposal. Alternatively, the char products can be accumulated for a 24-hour period for feed to the briquetting operation. 


\section{Liquids Storage and Handling}

The liquids storage and handling system is shown in Figure III-6 and described below.

Caustic is transferred from truck delivery to the caustic storage tank (D-501) and pumped to the vent gas scrubber by the caustic feed pump (P-501). Spent caustic from the scrubber is returned to the spent caustic storage tank (D-502). From there, it is fed to drum or truck loading by the spent caustic pump $(\mathrm{P}-502)$.

Sour water (condensate containing phenol and ammonium sulfide) from liquids recovery is stored in the condensate storage tank (D-503). It may then be pumped to the incinerator by the sour water transfer pump (P-503) if the quantity is small or to drum or tank truck loading for offsite disposal.

There are two storage tanks for each of the three primary hydrocarbon liquids. Each product has an associated run tank equipped with load cells for recovery and measurement of products produced during a 24-hour test period $(D-507, D-508$, and $D-509)$. In addition, long-term storage (D-504, D-505, and D-506) is provided to accommodate the products produced during the first 6 months of operation. The long-term storage was considered necessary to permit adequate analysis of the hydrocarbon products and to accumulate them for bulk delivery to a potential user.

\section{Material Balances}

Table III-7 presents a material balance for the mild gasification unit based on a $1: 1$ char recycle to coal feed and the product yields and compositions listed in section 2.1.3. The stream numbers in Table III-7 are keyed to the process flow diagrams in Figures III-2 through III-6.

As discussed above, the fraction of the gasifier heat supplied by char recycle affects the product gas composition. For the base case (1:1 char recycle to coal feed), approximately half of the gasifier energy is supplied by the recycled char. Appendix A presents material balances for $0.5: 1$ and $2: 1$ char recycle to coal feed ratios. The $2: 1$ char recycle to coal feed ratio is illustrative of the extreme, where all the gasifier heat is supplied by char recycle and therefore there is no nitrogen dilution of the product gases. 


\section{Energy Balances}

The thermal efficiency of the mild gasification process was estimated at 808, based on the higher heating value (HHV) of the feeds and products. This high thermal efficiency is attainable through heat recovery from the -incinerator flue gas. The details of the energy balance are summarized in Table III -8 .

Table III-8. OVERALL ENERGY BALANCE MILD GASIFICATIONa

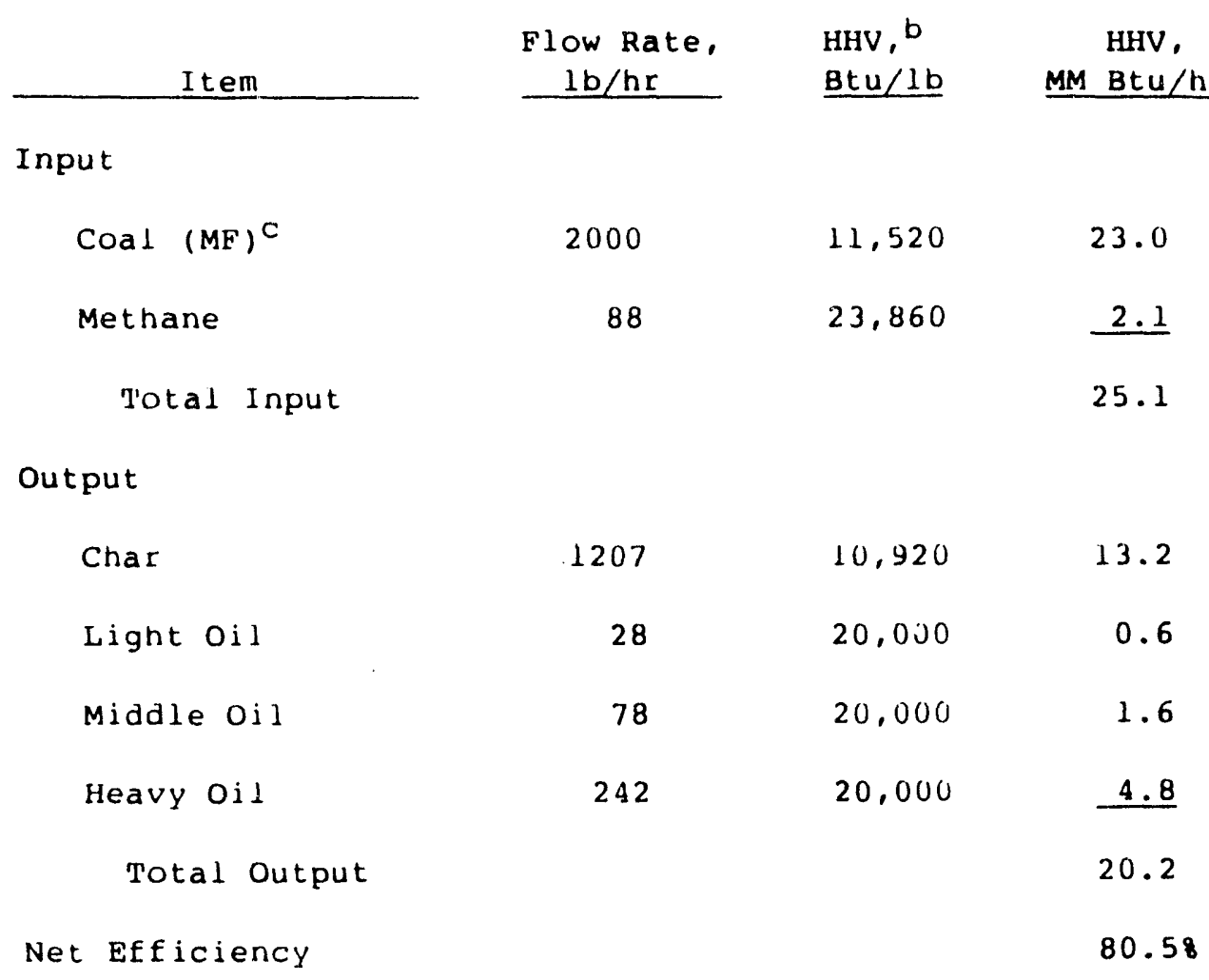

a Excludes heat losses compensated for by additional methane consumption.

b HHV = higher heat ing value.

C $M F=$ moisture-free.

Heat recovered from the incinerator flue gas is used to supply hot gases for drying coal and for reducing the heat duty of the gasifier char and booster heaters. Thermal cracking of the gasifier product gas imposes a 58 penalty on thermal efficiency. A portion of this energy can be recovered through proper heat integration of the thermal cracker with the gasifier; however, such an integration scheme would reduce the operating flexibility for evaluating the benefits of thermal cracking and has not been incorporated in the PDU. 
Only about 68 of the total energy input to the gasification unit is in the form of natural gas (methane). About 808 of the natural gas is consumed by the thermal cracker; the remainder is consumed in the incinerator. If -desired, the natural gas demand for the gasification process can be eliminated by substituting product oils (light oil and middle oil) for natural gas.

At this stage of the process design, no allowance has been made for heat losses from the equipment to the atmosphere. During detailed design, equipment and pipe insulation will be specified so as to minimize heat losses. An estimate of the expected heat losses will then be made and the methane consumption adjusted accordingly.

\section{Utilities Requirements}

In addition to the gasification process equipment, the process development unit requires the following process support and utilities facilities.

- Air supply. Air for the booster heater and char heater is provided by the process air compressor $(K-201)$

Natural Gas. Natural gas is required at the site to support the combustion in the incinerator and thermal cracker. For startup, natural gas is used to pressurize the gasifier and as makeup to the recycle gas. The gas is required at a pressure of 40 psia.

$\bullet$ Cooling water. The PDU mild gasification facility requires cooling water for the cooler-conveyors and for the light oil condenser. The mix of water and air cooling will be defined during the final design and construction.

- Plant Air. Dried instrument and service air is supplied from the existing systems available at the PDU site or from new facilities.

- Steam. There is no process steam in this preliminary design. If steam is needed for gasifier injection facilities will be added during the detailed design.

- Inert Gas Supply. Nitrogen for startup and shutdown purging is supplied from high-pressure cylinder trucks or from a rented liquid nitrogen system. Nitrogen is also used for pneumatic transport of char from the char lock hoppers to storage in a closed-loop system.

The preliminary estimates for utiliries requirements for the mild gasification process are as follows: 


$\begin{array}{ll}\text { - } & 260 \mathrm{gpm}^{\star} \\ \text { - } & 150 \mathrm{~kW}, 3.600 \mathrm{kWh} / 24 \mathrm{hr} \text {-day } \\ \text { - Steam } & 0 \\ \text { Natural gas } & 35 \mathrm{scfm} \\ \text { Normal } & 80 \mathrm{scfm} \\ \text { Startup } & 20 \mathrm{scfm} \\ \text { Plant air } & \\ \text { Nitrogen } & \\ \text { Normal } & \\ \text { Startup } & 2400 \mathrm{scf}\end{array}$

\section{Normal Operation and Controls}

The general operation of the PDU is described previously in the Process Description section. The normal operating adjustments and functions of the major gas distribution and heat balance controls are described below. An overall controls diagram is presented in Figure III-7.

\section{Char Recycle Control}

A portion of the heat input to the gasifier is derived by withdrawing char from the fluidized bed, heating it by partial combustion, separating the resulting gases, and returning the heated char to the bed. This cycle is controlled as follows:

- The char is withdrawn from the bed at a manually set flow rate (nominally some fraction of the coal feed rate).

- The withdrawn char is hot enough to sustain partial combustion as it is contacted with a controlled stream of air (which also serves to lift the char to the char cyclone for separation of the flue gas from the hot char).

- A controller monitors the temperature of hot char being returned to the gasifier and modulates the amount of air required for combustion in the char heater to achieve the desired char temperature.

\footnotetext{
* A higher temperature air-cooled, closed-loop cooling water system will be
} acceptable. 


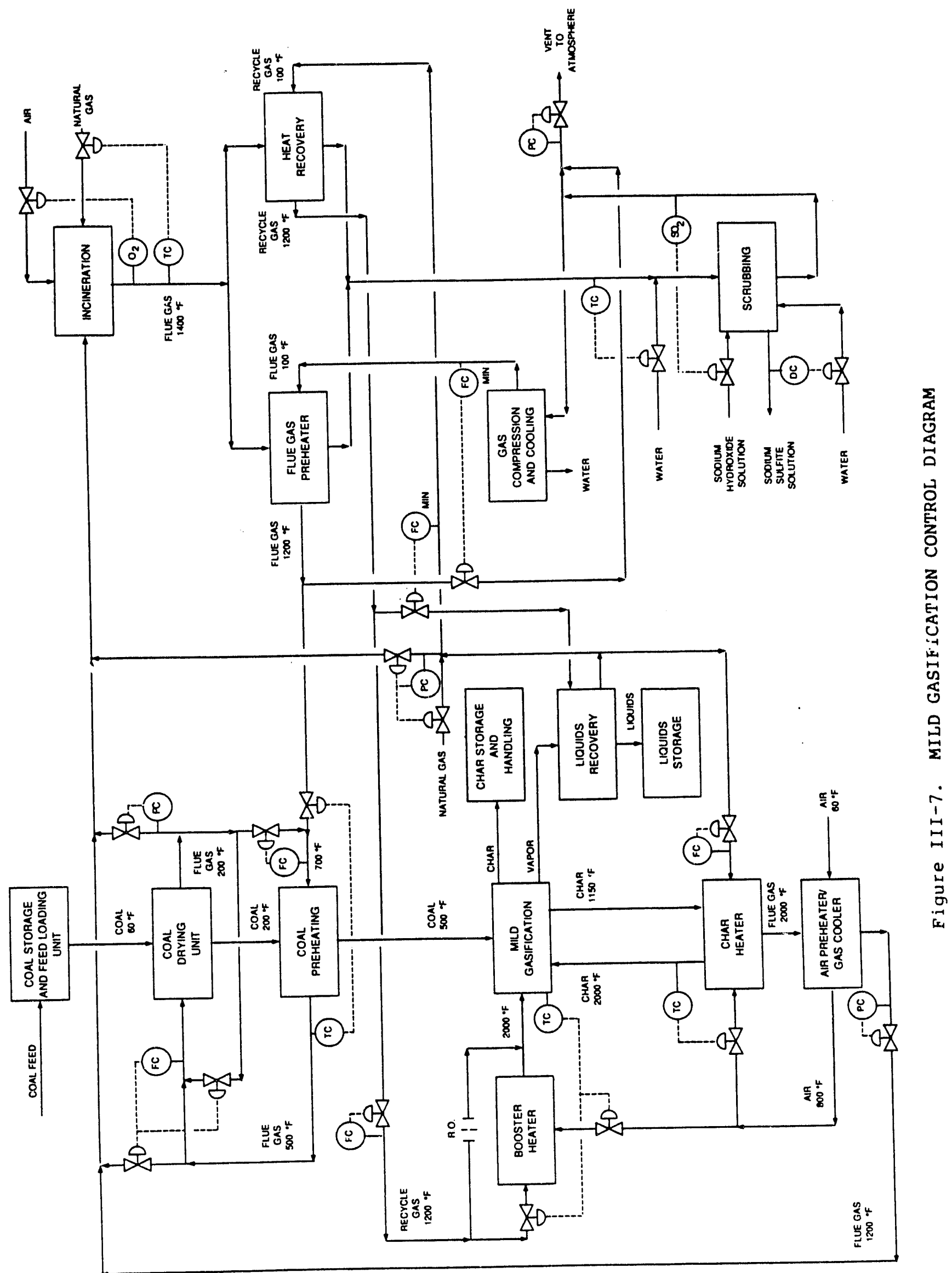




\section{Gasifier Fluidized Bed Temperature Control}

Char recycle supplies only a portion of the gasifier heat demand. The remaining portion of the heat demand is supplied by combusting a portion of the recycle gas used for fluidization. A controller monitors the temperature of the fluidized bed and simultaneously adjusts the recycle gas and airflow rates to the booster heater.

\section{Gasifier Entrained Bed Temperature Control}

The temperature of the entrained bed is regulated by the amount of coal fines fed to the entrained bed. Coal fines introduced to the entrained bed quench the exiting gas. The split of coal fines between the fluidized bed and the entrained bed affects the temperature of the exiting gases. The cycle is as follows:

- A differential temperature controller monitors the temperature difference between the fluidized bed and the exit temperature of the entrained bed.

- The controller acts to regulate the split of coal fines between the fluidized bed and the entrained bed to reach a desired differential temperature set point.

- Fines in excess of the controlled flow of fines to the entrained bed are combined with the coarse char feed to the fluidized bed.

The degree of fluidization depends on the amount of total hot gases introduced in the bottom of the gasifier. A flow controller on the recycle gas to the gasifier is used to set the total flow of recycle gas regardless of flow going to the booster heater. Combustion of recycle gas leads to dilution with air and an increase in gas flow to the gasifier. The heat demand of the gasifier varies the amount of recycle gas combusted in the booster heater (as controlled by the fluidized bed temperature). Fluidization in the gasifier therefore varies with temperature control. Control of fluidization is as follows:

- Differential pressure measurements on the fluidized bed indicate the degree of fluidization within the gasifier.

- The flow of recycle gas is set to achieve the desired degree of fluidization.

- Heat demand in the gasifier causes a fluctuation in the amount of fluidization gas. At steady state, this fluctuation should be small. 
Differential pressure measurements are checked routinely, and the appropriate change in recycle gas flow rate will be set on the flow controller.

\section{Gasifier Pressure Control}

The pressure of the gasifier cannot exceed the pressure of the recycle gas that is used for fluidization and injection of coal and char into the gasifier. The recycle gas pressure is maintained by back pressure control. Excess recycle gas is vented to the incinerator, and any shortfall of recycle gas pressure is made up by natural gas.

The pressure in the char heater is regulated by venting the char heater offgas on back pressure control to the incinerator after the offgas has been reduced in temperature by heat exchange with incoming combustion air.

\section{Coal Drying and Preheating}

The pressure in the coal drying and preheating section is regulated by back pressure control with excess gas being vented to the incinerator. The temperature of the gas exiting the coal preheater is monitored and used to control the amount of hot flue gas introduced to the coal preheater. The setting for the total flow of gases to the preheater is independent of preheater temperature. Dryer recycle gas is regulated to achieve the desired flow rate to the preheater.

Gas at a fixed temperature (that exiting the coal preheater) is sent to the coal dryer. The flow of gas to the coal dryer is independent of the flow rate in the preheater. Excess gas from lie preheater is vented to the incinerator and any shortfall of dryer gas is made up by recycling dryer vent gas.

\section{Emission System Control}

The incinerator is used to convert all sulfur containing species to $\mathrm{SO}_{2}$. Heat is recovered from the hot incinerator flue gases for preheating and drying coal and for heating recycle gas to the incinerator. The partially cooled incinerator flue gas is quenched and scrubbed with caustic to remove $\mathrm{SO}_{2}$. A portion of the scrubbed flue gas serves as the heat carrier to the coal preheating and drying section. Systems controls inc de the following:

- The temparature and the oxygen content in the incinerator are maintained at $1400^{\circ} \mathrm{F}$ and 38 , respectively, to ensure complete oxidation of sulfur- 
containing species. The incinerator temperature controller regulates the amount of natural gas necessary to achieve the desired temperature. An oxygen analyzer in the flue gas stream regulates the amount of air introduced to the incinerator.

The heat recovery tubes in the incinerator are protected from overheating by ensuring that a minimum flow of gas is maintained though the tubes. A minimum flow of scrubbed flue gas that is recycled for heat recovery is maintained by venting excess heated gas to the stack. Likewise, a minimum flow of recycle gas for heat recovery is maintained by venting excess heated gas to the liquids recovery section for heat removal. During normal operation, this flow is zero.

- The temperature of the incinerator flue gas going to the scrubber is monitored and regulated by water injection.

- The concentration of $\mathrm{SO}_{2}$ in the effluent from the caustic scrubber is controlled by the addition rate of caustic to the absorption section of the scrubber.

- The concentration of sodium sulfite leaving the scrubber is controlled by the flow of wash water added to the top of the scrubber.

\section{Safety}

The potential safety hazards for the PDU are typical for gasification and hydrocarbon handling systems. Operating procedures and controls are designed to ensure that explosive concentrations of air and gases do not develop within the process lines and storage vessels. Nitrogen is used for purging oxygen from the system and for blanketing storage vessels. After purging with nitrogen, natural gas is used to pressurize the gasifier and the liquid recovery system. Low-oxygen-content flue gas is employed for coal and char transport and for blanketing.

Gasifier product gas and recycle gas contain both $\mathrm{H}_{2} \mathrm{~S}$ and $\mathrm{CO}$. Care must be exercised to prevent exposure of operatizg personnel to these toxic gases. Proper ventilation is required, especially near rotating equipment, which is prone to leakage around seals. Area sensors for hydrocarbons, CO, and $\mathrm{H}_{2} \mathrm{~S}$ should be installed in key areas around the unit.

High-temperature streams are handled in the unit, and process lines need to be properly insulated for personnel protection.

All liquid product vessels are blanketed with nitrogen and vented to the incinerator. All liquid products, most notably the tar product, contain aromatic compounds. proper personal safety equipment should be used when 
handling the liquids. The PDU has been designed to minimize exposure of operating personnel to process liquids.

\section{Environmental Controls}

The PDU has been designed to meet tight emissions guidelines. All process gases are incinerated and scrubbed before being released to the atmosphere. Incineration is the most effective means of eliminating potentially hazardous organic compounds. Hydrocarbons are oxidized to $\mathrm{CO}_{2}$ and $\mathrm{H}_{2} \mathrm{O}$, and all sulfur species are converted to $\mathrm{SO}_{2}$. Caustic scrubbing of the incinerated gases permits removal of $\mathrm{SO}_{2}$ down to low levels.

All liquid products are stored in closed vessels, with vent gases being sent to the incinerator. The unit provides for onsite disposal of sour water by injection into the incinerator. If necessary, middle oil and light oil products can also be disposed of in the incinerator and used to reduce or eliminate the need for natural gas. Final cleanout of the liquid containing equipment prior to decommissioning will involve thorough washing with light oil to remove tars. Washings will be incinerated and the equipment purged with heated nitrogen followed by air to remove all trace volatiles.

\section{Startup Procedures}

The startup of the system from cold is conducted as follows:

- The coal dryer, preheater, gasifier, and the gas condenser train systems are purged with nitrogen to reduce the oxygen content below 1 percent volume (at ambient pressure).

- The gasifier and liquid recovery systems are brought up to operating pressure with natural gas.

- Oil circulation and cooling then begin in the liquid recovery train.

- The induced gas blower is started to lower the pressure in the incinerator below atmospheric pressure.

- The recycle gas compressor and the flue gas recycle compressor are started to establish flow through the incinerator heat recovery section.

- Gas firing of the incinerator is initiated to generate heat for coal drying/preheating and gasifier preheat.

- Gas scrubbing operations are initiated. 
- Gas recycle for the gasifier is established at the rate required to fluidize the fluidized bed.

- Gas recycle is established in the dryer/preheater loop at the rate needed for the required gas lifts.

- Hot flue gas is introduced to the coal preheater/dryer to establish a temperature of $500^{\circ} \mathrm{F}$ at the coal preheater exit.

A noncaking coke or char, sized to that of the selected feed coal, is fed to the dryer/preheater to establish a normal char level in the gasifier.

- The char recycle loop is started and circulated using recycle gas for gas lift.

- The recycle booster heater is fired to bring the gasifier to operating temperature. Natural gas may be introduced to increase the heating value of the recycle gas.

- Coke feed is continued, and normal char product offtake and system temperatures and pressures are established.

- A l:l mixture of coal and coke is introduced to the gasifier through the dryer/preheat system. The coke is gradually replaced with coal (the process typically taking 1 hour) until the unit is operating on coal feed only.

- The coal feed rate is gradually increased to establish the desired flow rate.

- As combustible pyrolysis gas enters the recycle and char heater, the heating value of the recycle gas increases and natural gas addition to the recycle gas is reduced or eliminated.

- As coal-derived liquids displace any startup liquids in the condensing train, normal product of take is begun.

The above sequence completes the normal startup of the gasification process.

\section{Standby}

Once operation of the gasification system has been established, feed may be interrupted and the unit held in hot standby to facilitate a restart. This is accomplished in the following way:

- The screw feeder transferring coal to the dryer is halted, and fluidization of preheater coarse and fine coal to the gasifier is stopped. Coal is retained in the dryer and preheater surge vessels.

- The gasifier char discharge cooler/conveyor is shut down. 
- The recycle gas flow to the gasifier is reduced to ininimize char entrainment from the bed.

- Natural gas is automatically introduced to the inlet of the recycle gas booster burner so that combustion may be continued as needed to retain the gasifier bed temperature.

- The temperature control setting on the outlet gas from the coal preheater is reduced to that of the normal dryer outlet temperature.

Tar and middle oil circulation is stopped to reduce its evaporative carryover. (Gas cooling is maintained by the middle oil and light oil quench coolers.)

- Incinerator firing is maintained at a low level to accommodate any minor emissions.

The gasification system can be held in this mode for an extended period and, since the components are maintained near operating temperatures, it can be restarted quickly with introduction of coal feed.

\section{Shutdown}

Shutdown, which may be required for maintenarice access, follows the procedure for standby, except that:

- The char contents of the gasifier are discharged through the bottom dump value of the gasifier.

- The system is allowed to cool, and the gaseous contents are purged with nitrogen through the incinerator.

- Coal contained in the seal legs of the dryer and in the preheated coarse and $f$ ine coal cyclones is discharged from the bottom dump valve on the dryer and preheater lift pipes.

- Liquid inventories are pumped to storage.

- When free of hydrocarbon, the systems are purged with air prior to being cleared for entry.

\section{Approach to Steady-State Following Startup and/or Feed Change}

Steady-state operating conditions in the gasifier are approached as the fluicized bed contents are replaced with equilibrium char representative of the coal feedstock. Based on IGT experience with its $100 \mathrm{lb} / \mathrm{hr}$ PRU, six to seven bed turnovers are necessary to replace $99+8$ of the initial char inventory with char that is characteristic of the new coal feed. This number of bed turnovers corresponds to a time period of about 9 hours under typical PDU operating conditions. 
The approach to steady state in the liquid product recovery section involves the replacement of liquid inventories in product receivers and recirculation lines. Liquid holdup in the tar/heavy oil quench system accounts for most of the liquid inventory and is therefore the controlling factor in the approach to steady state of the liquid product recovery section. Steady-state concentrations are reached in the tar/heavy oil quench system after 8 hours of flushing by new products.

When coal feeds are switched, steady-state conditions for the combined system (gasifier and product recovery section) are controlled principally by the time for the gasifier to attain equilibrium. The PDU will attain equilibrium within 10 hours (eight to nine gasifier volumes) under typical conditions after the new coal feedstock is introduced.

Special Equipment Designs

Coal Dryer and Preheater

The coal dryer and preheater are two 8 in. dia. lift pipes, 60 feet high. Coal is fed to the dryer lift pipe at its base by a compacting screw feeder. This compacted feed, together with the static inventory of coal in the screwer feeder and surge vessel, provides a gas seal. The hot gas introduced at the bottom of the lift pipe entrains the coal and heats it. The gas and coal are then separated in a cyclone. Dried coal accumulated in the coal dryer surge vessel is transported to the preheater lift pipe via dense phase fluidization. The inventory in the dryer surge vessel provides a gas seal between the dryer cyclone and the preheater. The key design parameters are the residence time of the coal in the lift pipe and the temperature and the velocity of the hot gas.

\section{Gasifier}

Figure III-8 shows the proposed mild gasifier. This vessel is configured according to the design parameters described in the section on system capacity. The inventory in the coal feed surge vessels and the char withdrawal screw conveyors (char recycle and char removal) provides the required gas seal for the gasifier.

\section{Hot Gas/Char Fines Separation}

The hot gas and char fines leaving the gasifier pass through two cyclones before entering the thermal cracker. The cyclones separate most of the char 


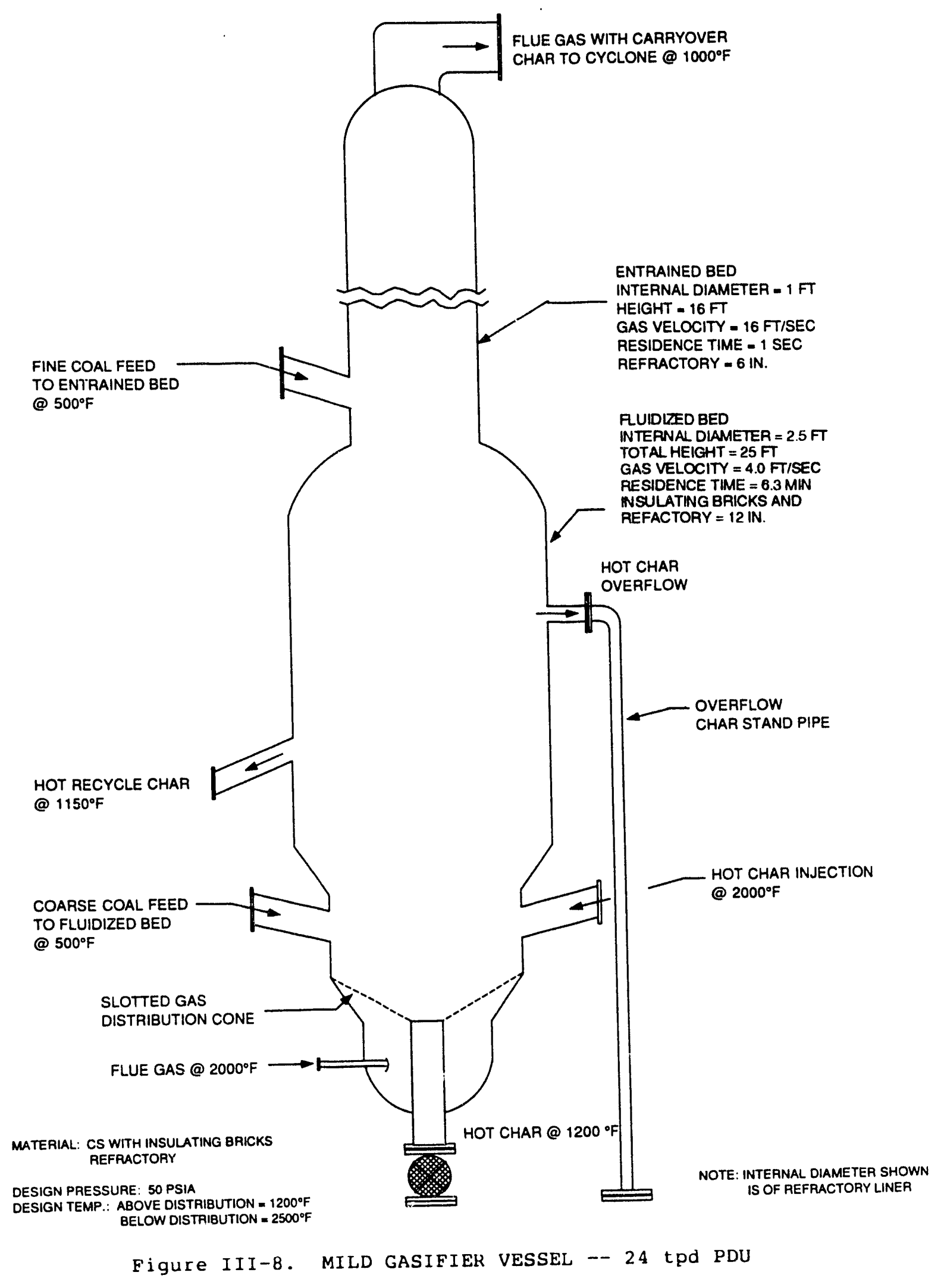


from the hot gas. Very fine char passes through the cyclones and the thermal cracker into the liquids recovery system.

\section{Char Heater}

The char heater is a 12 in. dia., 60-foot-high ceramic-lined lift pipe in which the air for partial combustion serves as the fluidizing medium. Warm char is injected into the lift pipe/burner by a compacting screw feeder. The heated char is separated from the partial combustion gases by a refractorylined cyclone and returned through a seal leg to the gasifier.

\section{Thermal Cracker}

The thermal cracker consists of a gas-fired indirect heater with a residence time loop. The residence time and temperature are the key design parameters for the thermal cracker. A removable refractory-lined residence time loop allows the residence time of gases to be varied before the gases are quenched in the liquids recovery section.

\section{Tar Recovery}

The tar recovery system permits the gas to be cooled quickly while avoiding plugging due to buildup of condensed tar on cool surfaces. In addition, the tar quench system must handle char fines entrained through gasifier cyclones. Tar is recovered via direct quench of the flue gas with recirculated product tar. To prevent plugging of the inlet gas nozzle, the high inlet gas velocity to the tar quench condenser is maintained. Gas is introduced tangentialiy to maintain a high velocity at the walls. Recirculated tar product is sprayed into the gas, and surfaces are maintained wetted to wash away condensed solids. Perforated plates provide gas-liquid mixing and a wetted surface area for condensation.

Fines entrained into the quench condenser end up as suspended solids in the tar product. A fines bypass filter removes the bulk of the fines from the recirculated tar. Product filters provide a means for removal of residual fines from the tar product.

An air-cooled exchanger has been froposed for cooling the recycle tar. During the final design, this cooler will be reexamined with a view to reducing the tar inventory. The intent is to accelerate the approach to steady state of the tar recovery system. 
FORM COKE PROCESS CONCEPTUAL DESIGN

\section{Design Basis}

The overall block diagram for the form coke process is illustrated in Figure III-9. The feed to the form coke process is char from the mild gasification process and dried coal. The feed mixture is first ground and heated to $1000^{\circ} \mathrm{F}$. Heating produces a plastic mass which is thoroughly mixed to achieve uniformity and subsequently formed into briquettes and calcined at temperatures up to $1800^{\circ} \mathrm{F}$. Coal volatiles driven off in the calciner and the mixer/heater are incinerated and sent to the scrubber in the mild gasification process. The calcined briquettes are cooled and screened to remove $f$ ines. Lignosulfonate solution may be applied to the form coke product to increase abrasion resistance and to reduce water adsorption.

\section{System Capacity}

The form coke process has been designed to accept 28 tpd of mixed char and coal feed. The capacity of the process was selected to meet the following criteria:

- Adequate storage and capacity to process char produced by the mild gasification process

- Storage capacity and processing capacity to produce form coke from a $1: 1$ mixture of coal to char

\section{Design Operating Parameters}

The form coke process is designed to operate independently of the coal drying and gasification processes. This independence of operation is one of the design operating parameters that have been selected by IGT for the test operation. The other parameters, along with their maximum, base case, and minimum values, are listed in Table III-9.

\section{Yields and Compositions}

A yield structure for the form coke process was developed on the basis of the volatiles content of the coal feed, gasifier char, and the form coke product. The char volatiles content depends on the gasifier operating conditions. The compositions shown in Table III-10 were assumed for the base case design. 


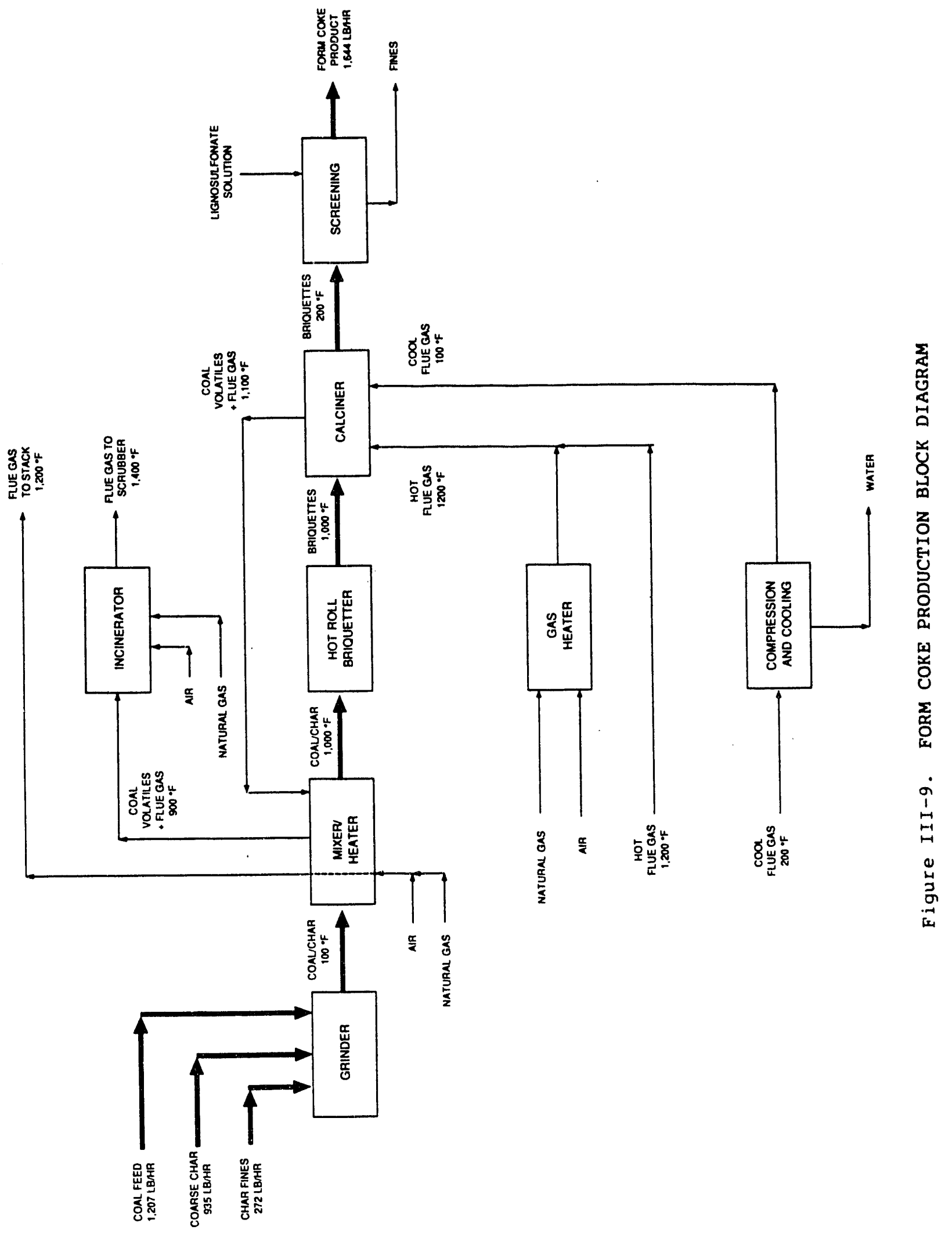


Table III-9. OPERATING PARAMETER RANGES FOR THE FORM COKE PROCESS

\section{Parameter}

Calciner Operating Pressure, psia Char/Coal Feed Ratio, lb/lb

Total Feed, lb/hr

Feed Size, Mesh

Ground Feed Size, Mesh

Residence Time, min

Mixer/heater

Calciner

Temperature, ${ }^{\circ} \mathrm{F}$

Mixer/heater

Calciner
Maximum

20

2400

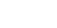

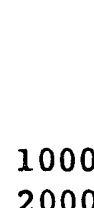

2000

\section{Base Case Minimum}

12

0.5

2400

$6 \times 0$

TBD

120

1000

1800

N/A

1200

Table III-10. COMPOSITION IN WEIGHT PERCENT OF THE COAL FEED, GASIFIER CHAR, AND THE FORM COKE PRODUCT

\begin{tabular}{|c|c|c|c|c|}
\hline Item & Moisture & $\begin{array}{l}\text { Volatile } \\
\text { Matter } \\
\end{array}$ & Carbon & Ash \\
\hline Coal Feed (Illinois No. 6) & 3.32 & 35.23 & 47.34 & 14.11 \\
\hline $\begin{array}{l}\text { Gasifier Char } \\
(1: 1 \text { vhar recycle) }\end{array}$ & 0 & 14.94 & 60.93 & 24.13 \\
\hline Form Coke Product & 0 & 1 & $\begin{array}{l}\text { By } \\
\text { material } \\
\text { balance }\end{array}$ & $\begin{array}{l}\text { By } \\
\text { material } \\
\text { balance }\end{array}$ \\
\hline
\end{tabular}




\section{Process Description}

Figure III-10 shows the proposed process flow for form coke production. The base case material balance in Table III-11 is keyed to the flow diagram.

\section{Feed Preparation}

The briquetting operation has been designed to run independently of the gasifier; however, the gasification section emissions control and char handling system must be operated to supply necessary heat and to provide adequate environmental control. Feeds to the briquetting operation consist of coarse and fine char from gasification, along with dried coal. The char feeds are accumulated batchwise from operation of the gasifier. Dry coal feed for form coke production is obtained by operating the coal feed and drying section of the PDU and storing the dried coal in the dry coal storage vessel (D-601). The PDU could permit simultaneous operation of both the briquetting and mild gasification operations with slight modification. The modification would require additional coal drying capacity or purchase of predried coal for form coke production.

The feed grinder $(Y-602)$ accepts coarse char, char fines, and dry coal to prepare a finely ground coal/char mixtuse. The feeds are metered into the grinder by rotary feeders, and flow rates are determined from weight loss of the storage vessels. An elevating screw conveyor (Y-603) transports the ground feed to the mixer/heater $(\mathrm{Y}-604)$.

The mixer/heater uses a gas-fired burner to indirectly heat the feed to $1000^{\circ} \mathrm{F}$ while providing mixing to produce a uniform composition. A portion of the heat supplied in the mixer/heater is from direct contact of hot calciner offgases, which are passed through the mixing chamber. Devolatilization of the coal feed takes place in the mixer/heater, and the coal volatiles are vented, along with the calciner offgases, to the incinerator (F-602).

The heated coal/char mixture flows by gravity into the hot roll briquetter $(Y-605)$, which compresses the mixture into briquettes at $1,000^{\circ} \mathrm{F}$. The hot briquettes drop directly from the briquetter into the vertical shaft calciner $(\mathrm{C}-601)$.

The briquettes travel downward as a moving bed through two zones in the vertical shaft calciner. In the top zone, the briquettes are heated to $1800^{\circ} \mathrm{F}$ with a countercurrent flow of flue gas at $2000^{\circ} \mathrm{F}$; in the bottom zone, heat is 


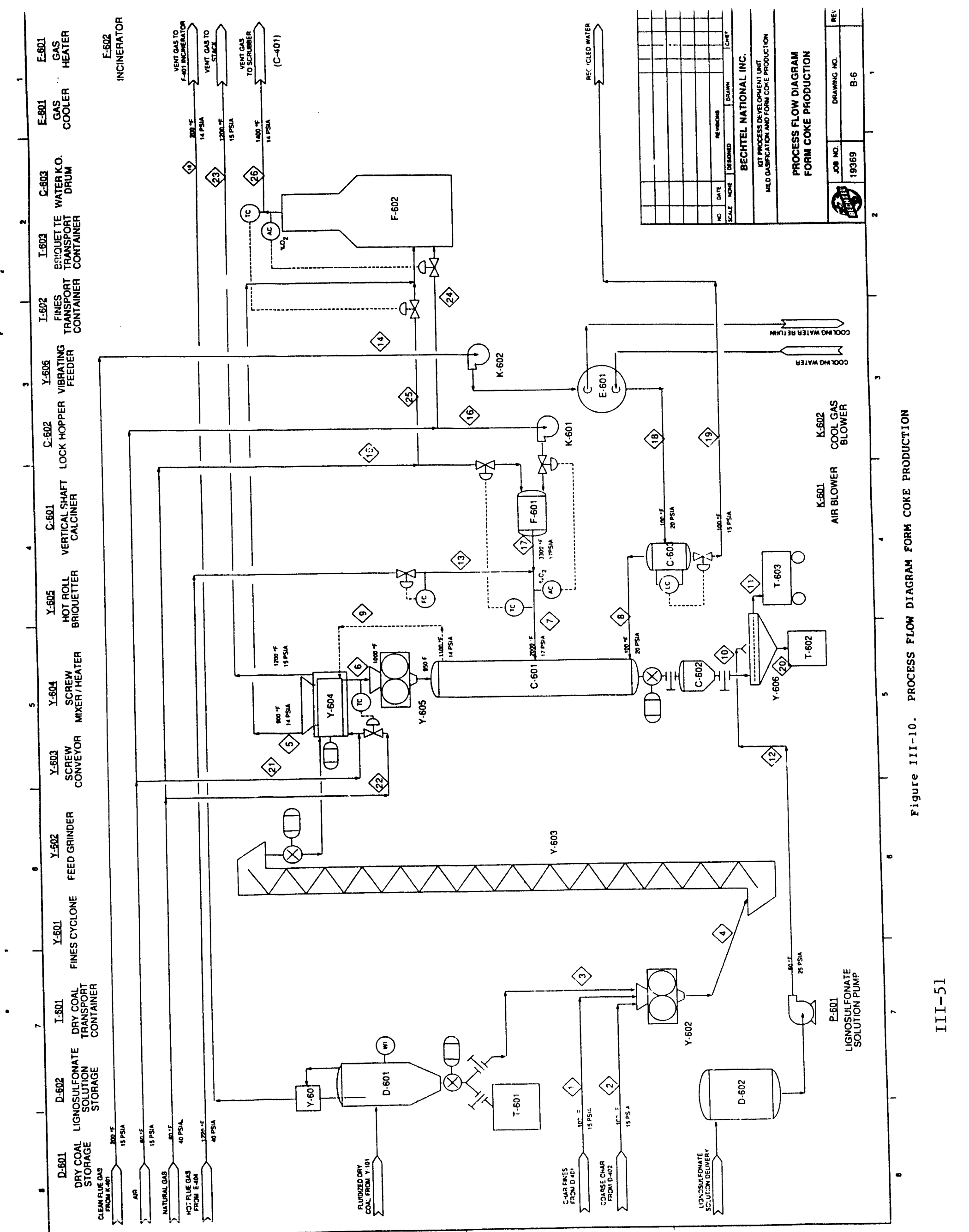




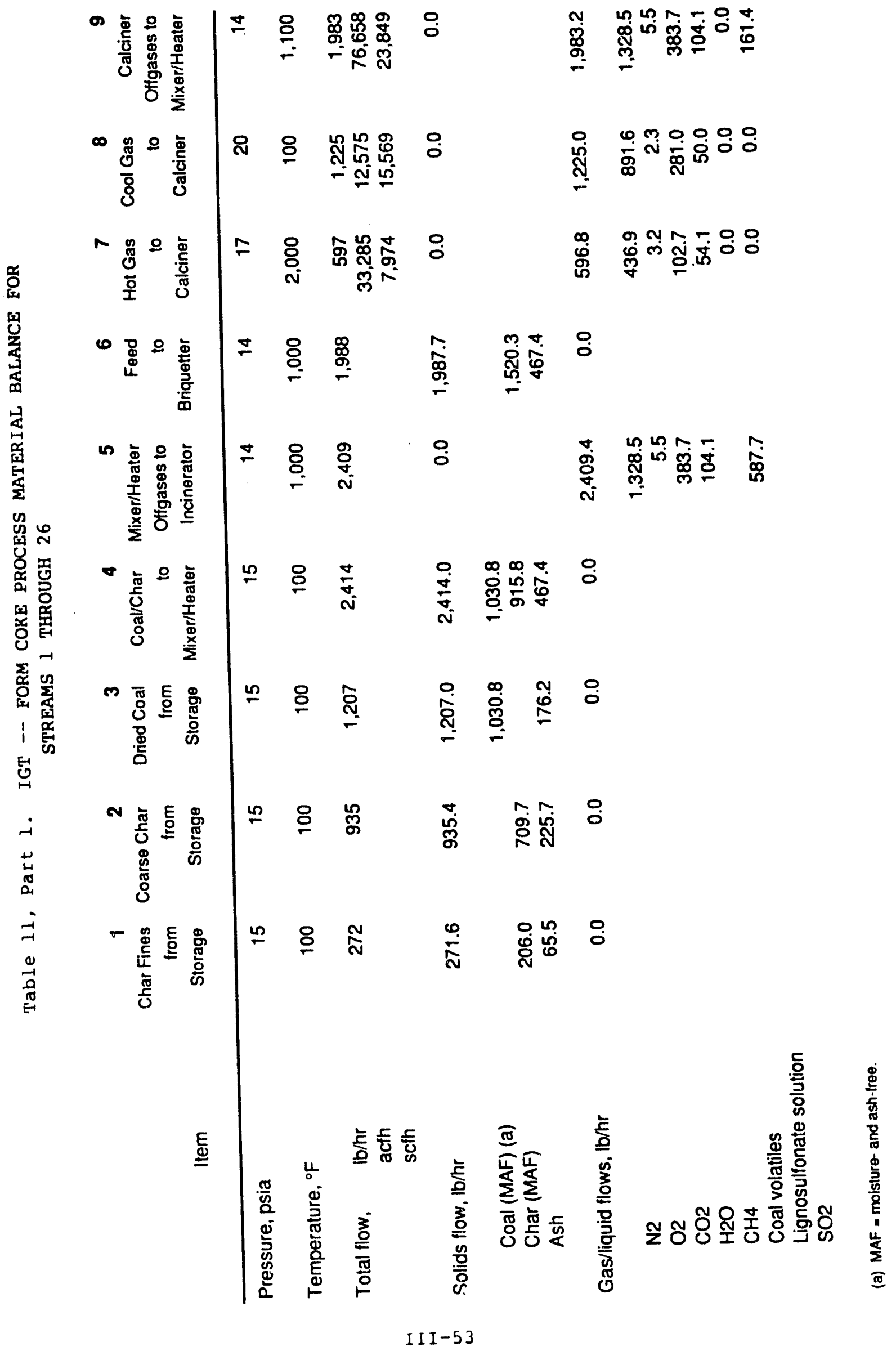




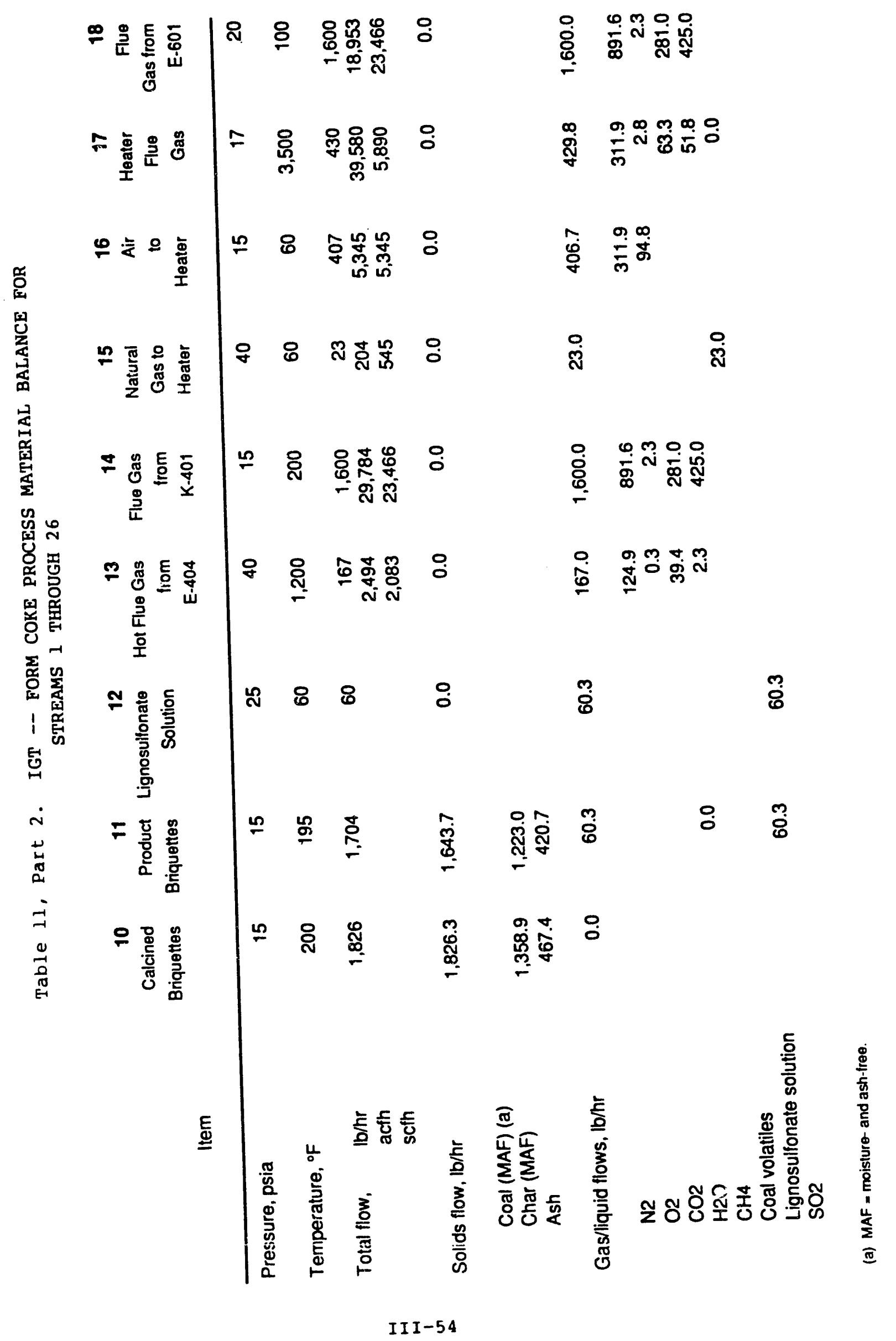




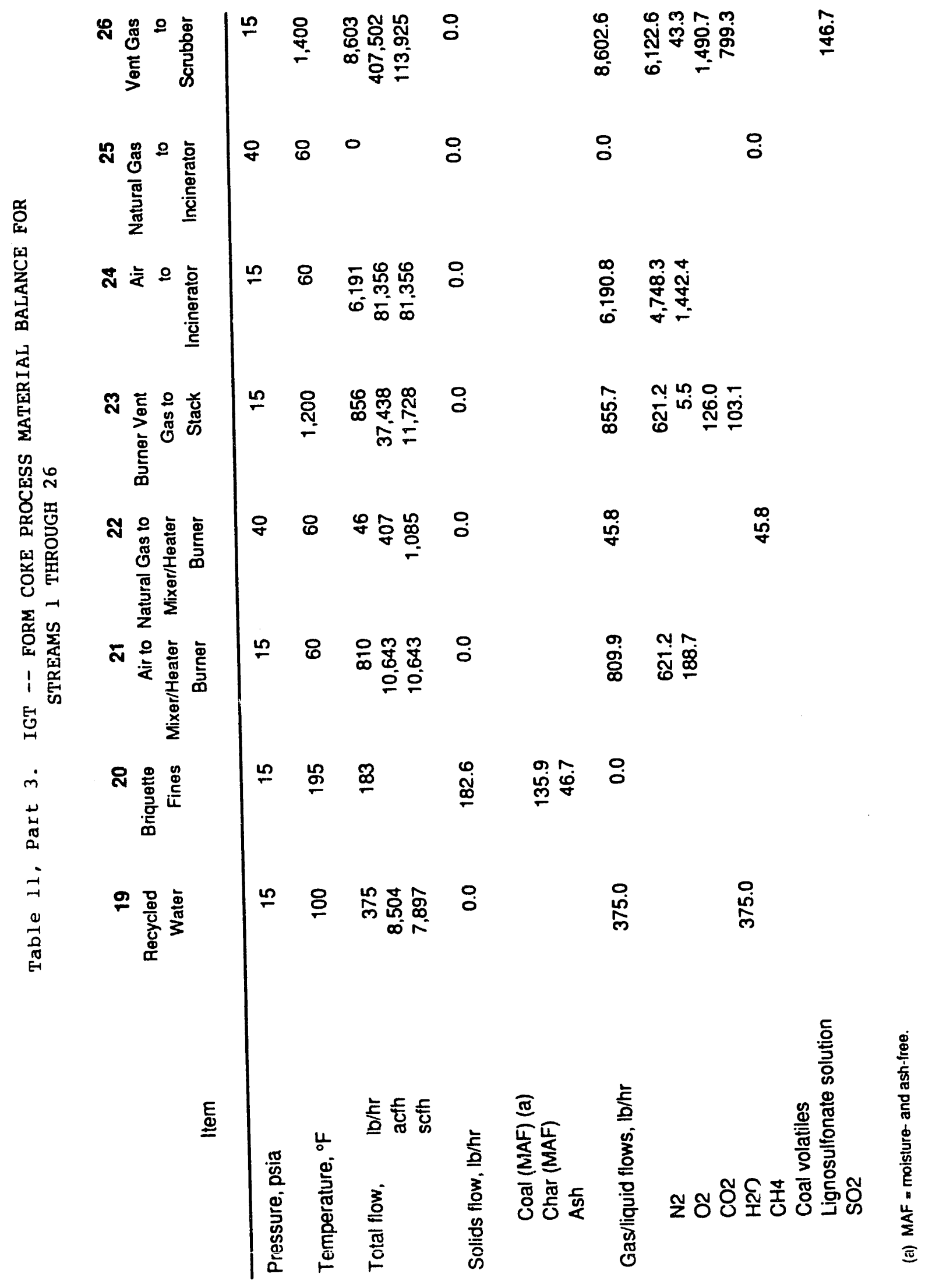


recovered from the briquettes with countercurrent flow of flue gas at $100^{\circ} \mathrm{F}$. Briquettes exit the calciner at $200^{\circ} \mathrm{F}$ through a lock hopper (C-602). The hot flue gas for calcining the oriquettes is obtained by boosting the temperature of recycled flue gas obtained from the incinerator (F-401) in the emissions control and char handling system. The flue gas temperature is boosted from $1200^{\circ} \mathrm{F}$ to $2000^{\circ} \mathrm{F}$ by introducing heat from a direct-fired gas heater (F-601). Natural gas is burned in the gas heater, and an air blower ( $K-601)$ supplies the necessary air for combustion. Clean flue gas from the scrubber is cooled to $100^{\circ} \mathrm{F}$ with cooling water $(E-601)$, and condensed water is separated in a water knockout drum $(C-603)$. The cool gas blower $(K-602)$ causes flue gas to circulate from the scrubber to the calciner.

Briquettes leaving the lock hopper are conveyed to a transport container ( $T-603)$ by means of a vibrating screen feeder (Y-606), which separates the form coke product from fines. To increase the briquettes' resistance to abrasion and water ausorption, a lignosulfonate solution may be sprayed on the form coke product exiting the screen. A pump (P-601) furnishes the required pressure to move the lignosulfonate solution from storage (D-602) through the spray nozzle.

\section{Material Balance}

Table III-11 presents a material balance for the form coke production process for the base case design. The stream numbers in Table III-11 are keyed to the process flow diagram in Figure III-10. The base case design assumes form coke production from a $1: 1$ coal/char feed mixture.

\section{Energy Balance}

An overall energy balance was performed for the form coke process, assuming the higher heating value of the feeds ard products. The net thermal efficiency was estimated to be 668 . The details of the energy balance are summarized in Table III-12.

The thermal efficiency of the form coke process is considerably lower than that of the gasification process ( 668 versus 818 for gasification). Hot flue gas leaving the incinerator accounts for over 208 of the energy input. Incineration was chosen for disposal of the coal volatiles to permit operating flexibility and to reduce capital expenses. Increased thermal efficiency can be attained through heat recovery from the incinerator effiuent 
Table III-12. OVERALL ENERGY BALANCE FORM COKE PRODUCTIONa

\begin{tabular}{lll} 
Item & $\begin{array}{l}\text { Flow Rate, } \\
\text { lb/hr }\end{array}$ & HHV , \\
\hline
\end{tabular}

Input

$\begin{array}{lrrr}\text { Coal }(M F)^{c} & 1207 & 11,520 & 13.9 \\ \text { Char (MF) } & 1207 & 10,920 & 13.2 \\ \text { Methane } & 69 & 23,860 & 1.6 \\ \text { Total Input } & & & 28.7\end{array}$

Output

$\begin{array}{lccc}\text { Briquettes } & 1644 & 10,400 & 17.1 \\ \text { Briquette Fines } & 183 & 10,400 & 1.9 \\ \quad & & 19.0 \\ \text { Total Output } & 66.28 \\ \text { Efficiency (HHV) } & \\ \text { Excludes heat losses compensated for by additional methane } \\ \text { consumption. } \\ \text { HHV = Higher heating values. } \\ \text { MF = moisture-free. }\end{array}$

in a manner similar to that employed for the gasification process. The heating value of the coal volatiles generated by the process is in excess of that for the natural gas requirement for the process. A commercial plant would benefit by recovery of heat from the incineration of the coal volatiles or through use of the coal volatiles in fired equipment (i.e.. the gas heater and screw $\mathrm{mixer} /$ heater).

\section{Utilities Requirements}

In addition to the process equipment described above, the form coke process requires the following support and utilities facilities:

- Air supply. Air for the gas heater is provided by the process air blower $(\mathrm{K}-60 ?)$.

- Natura. Gas. Natural gas is required for indirect heating of the $\mathrm{mixer/heater}$ and direct heating for the calciner gas heater. At steady state, the neating value of the ccal volatiles evolued by the process is 
adequate to supply the necessary heat for the incinerator. For startup, natural gas is used in the incinerator. The gas is required at a pressure of 25 psia.

- Cooling Water. The form coke process requires cooling water only for the gas cooler.

- Plant Air. Dried instrument and service air is supplied from the existing systems available at the pDU site or from new facilities.

- Steam. There is no process steam in this preliminary design.

- Inert Gas Supply. Nitrogen for startup and shutdown purging is supplied from high-pressure cylinder trucks or from a rented liquid nitrogen system.

The preliminary estimates for utilities requirements for the form coke process are as follows:

- Cooling water

- Eiectricity

- Steam

- Natural Gas * *

Normal

Startup

- Plant air

- Nitrogen

Norma 1

Startup
$<5 \mathrm{gpm}^{\star}$

$80 \mathrm{~kW}, 1,920 \mathrm{kWh} / 24 \mathrm{hr}-\mathrm{day}$

0

$30 \operatorname{scfm}$

$30 \operatorname{scfm}$

5 scfm

4 sctm

450 scf

* A higher temperature air-cooled, closed-loop cooling water system will be acceptable.

* * This includes the emission control system requirement.

Normal Operation and Controls

The general operation of the form coke process was described previously in the process Description section. The normal operating adjustments and functions of the major gas distribution and heat balance controls are described below. Ar overall controls diagram for the form coke is presented in Figure III-II. 


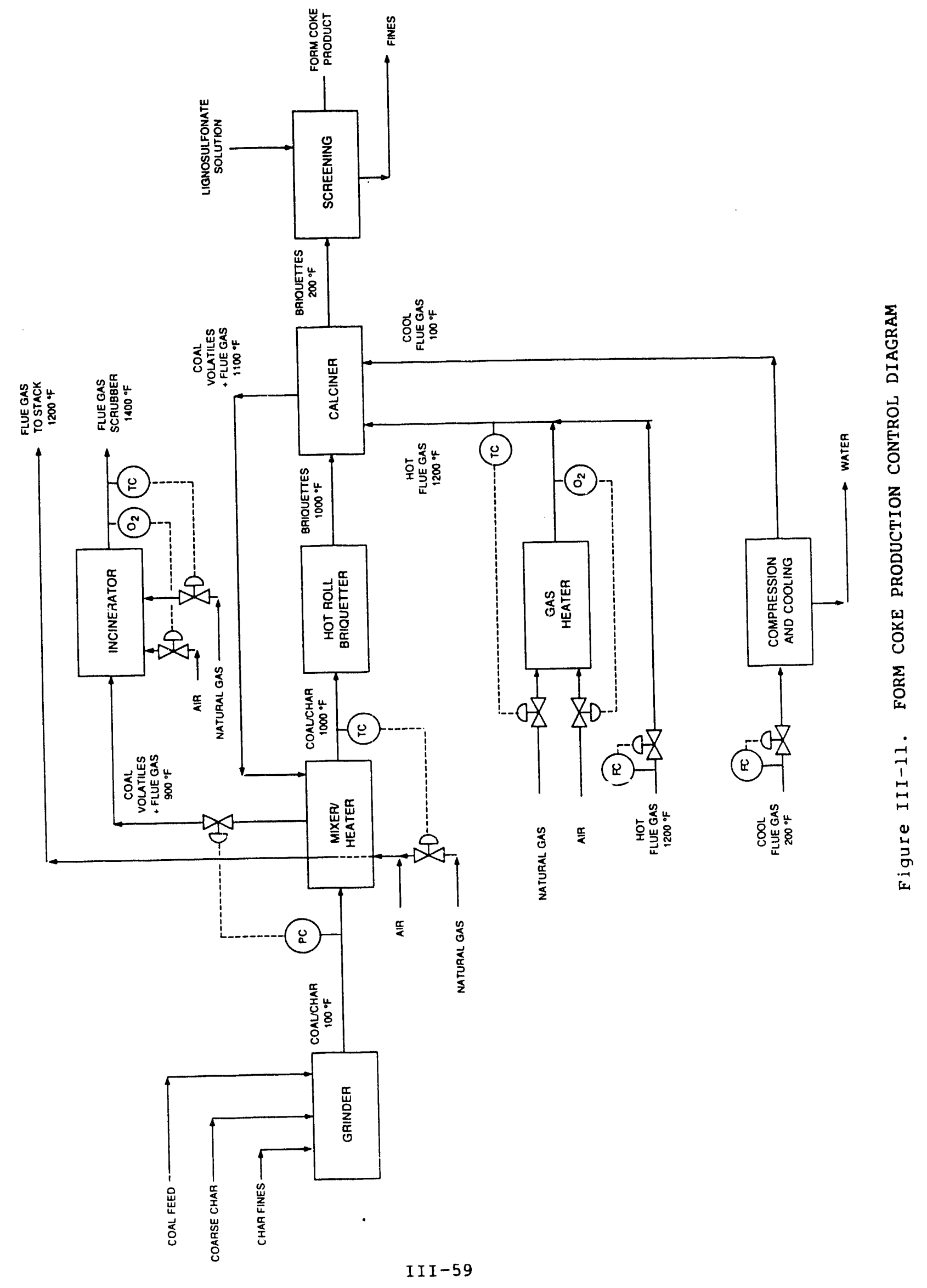




\section{Mixer/Heater Temperature Control}

The primary mode of heat input to the mixer/heater is through indirect heating with natural gas. The temperature of the plastic mass exiting to the briquetter is maintained by modulating the flow rate of natural gas to the indirect heater. The natural gas is combusted with excess air, and the hot gases pass ihough the mixer/heater shell to supply heat through the mixer/heater walls.

A small portion of heat is supplied to the mixer/heater through direct contact of hot calciner vent gas with with plastic mass inside the mixer/heater. The temperature control mechanism described above controls the additional heat input required.

\section{Calciner Temperature Control}

The calciner is a vertical shaft furnace with heating and cooling zones. Heat to the mixer heater is supplied by passing hot flue gas countercurrent to a moving bed of briquettes. Hot flue gas at $1200^{\circ} \mathrm{F}$ is supplied to the form coke process from the gasification incinerator (F-401). The hot flue gas temperature is boosted to about $2000^{\circ} \mathrm{F}$ with a direct-fired gas heater. The temperature of hot gas to the calciner is controlled by modulating the flow of natural gas to the direct heater. Excess air to the direct heater is kept to a minimum by adjusting the airflow on the basis of the oxygen content of the hot flue gas.

Cool flue gas is introduced in the bottom of the calciner to cool the briquettes and to recover heat for calcination. After recovering heat from the exiting briquettes, this flue gas combines with the hot flue gas $\left(2000^{\circ} \mathrm{F}\right)$ to supply heat to the incoming briquettes. Temperature measurements inside the calciner help the operator establish the proper flow of hot and cool gases necessary for calcination and cooling. The flows rates of hot and cool gases are adjusted independently with separate flow controllers.

\section{Incinerator Temperature Control}

A flue gas temperature in excess of $1400^{\circ} \mathrm{F}$ is specified for the incinerator to ensure that all hazardous compounds are properly oxidized. Under normal conditions, combustion of the coal volatiles in the incinerator feed should supply the heat requirement of the incinerator. Natural gas is used to make up any shortfall of heat required in the incinerator and is

$$
\text { I I I }-60
$$


controlled through temperature measurement of the exiting flue gas. The air required for combustion is modulated on the basis of the measured oxygen content in the flue gas.

\section{Pressure Control}

A pressure controller is necessary to provide adequate back-pressure on the mixer/heater to avoid gas flow between the feed preparation equipment (grinder and screw conveyor) and the mixer/heater. Excess pressure in the mixer/heater can cause backflow of combustible gases (i.e., coal volatiles) into the screw conveyor, leading to the formation of an explosive gas mixture in the feed preparation equipment and/or leakage to the environment.

Likewise, subatmospheric pressure in the mixer/heater is possible and can lead to the drawing in of air from the screw conveyor to form an explosive gas mixture in the mixer heater.

\section{Startup Procedures}

Operation of the form coke process depends on operation of the PDU emission control system. The emission control system is designed to run independently of the gasifier and is brought on line during the first phase of gasification process startup.

The startup of the form coke process is conducted as follows:

- The PDU emission control system is started up following the steps summarized for the gasification process. These startup steps are followed up to and including startup of the gas scrubber. Inert purging and initial pressurization of the coal dryer'preheater and the gasifier are not necessary for stand-alone operation of the form coke process.

- The unit is purged with nitrogen at atmospheric pressure to reduce the oxygen content to less than 18 .

- The incinerators are started up using supplemental natural gas.

- The unit is brought to operating pressure by introducing cool flue gas via the cool gas blower. Startup of the cool gas blower requires initiation of cooling water flow through the gas cooler and establishing a liquid level in the water knockout drum.

- The screw mixer/heater is slowly warmed by burning natural gas in the indirect heater.

- The calciner is brought up to operating temperature by introducing hot flue gas from the emissions control section. Once gas flow has been initiated, the desired temperature of the hot gas is attained by startup of the direct gas heater and the associated air blower. 
- The grinder is started, and the various feeds are introduced.

- The operating speeds of the mixer/heater and briquetter are adjusted to correspond to the feed rate.

- The vertical shaft is first filled with form coke; then an appropriate timing sequence is initiated for the lock hopper operation.

\section{Standby}

Once operation of the form coke process has begun, briquette production may be put into hot standby for intervals of minutes to hours at a $t$ ime. In hot standby sampling, minor equipment troubleshooting and other tasks may be performed, with the process unit available for an immediate restart. The process is brought to the hot standby condition in the following way:

- The coal and char feeds and the feed grinder and the screw conveyor are stopped. Coal is retained in the screw lift conveyor.

- The screw mixer/heater is stopped, and the burner heat output is brought to a low level. The briquetter is stopped after it and the screw mixer/heater have been emptied of feed.

- The calciner hot flue gas stream is shut down with the stoppage of the screw mixer/heater. The low level of volatile emissions will be retained by the cooling briquettes and equipment.

- The gas heater is brought to a low firing level (or turned off).

- The cool gas blower is operated at a low flow setting to maintain a temperature gradient in the calciner.

- After the coal inventory in the screw mixer/heater and the calciner has been emptied, the form coke incinerator can be shut down (if required)

- Incinerator (F-401) firing is maintained at a low level to accommodate any minor emissions.

The guidelines given above will facilitate a rapid restart of the form coke process after minor maintenance and sampling have been performed. Most operations requiring that the form coke production process be brought to hot standby may be done while the inventories in the screw mixer/heater are being depleted. Specific actions to achieve a hot standby condition in response to scheduled activities and process upsets will be developed through final design and will be included in a PDU operating plan. 


\section{Shutdown}

Shutdown is carried out using the same procedure as above for standby except :

- Coal continues to be ground and fed into the the screw mixer/heater until the screw conveyor is empty.

- The burner for the screw $m i x e r / h e a t e r$ is shut off when it has no coal.

- The calciner operates until the calcining section is emptied of briquettes. The gas heater is then shut of $f$, and the hot flue gas is turned down to low heat.

- When all briquettes have been discharged out of the calciner, then the emission control section, the incinerator, and all associated equipment can be shut down.

- The system is allowed to cool, and the gaseous contents are purged with nitrogen through the incinerator.

- When free of hydrocarbon, the system is purged with air prior to being cleared for entry if personnel access is required.

\section{Special Equipment Designs}

\section{Mixer/Heater}

The sclew mixer/heater thoroughly mixes the coarse char, char fines, and coal feed while these are being heated to $1000^{\circ} \mathrm{F}$. The design of the unit includes a system of three screws for conveying and mixing, and a burner that indirectly heats the mass up to temperature. Two of the three screws move solids in the direction of the process flow, and the third moves solids in the reverse direction to provide the mixing action. The heat input is controlled by varying natural gas and air to the external burner to maintain the outlet solids at the desired temperature. Volatiles leaving the coal/coke mixture are removed in a disengaging space, vented to an incinerator, and then scrubbed in the emission control section.

\section{Hot Roll Briquetter}

The hot, plastic mass output of the screw mixer/heater is formed into briquettes in a hot roll briquetter. Since the feed to this unit is already at an elevated temperature, a great amount of pressure for forming briquettes is not required. 


\section{Calciner}

The calciner completes the conversion of the briquettes into form coke. This unit is designed co provide 1 hour of retention for calcining followed by 1 hour of cooling. The calciner has an internal diameter of 3.1 feet and internal height of 12.5 feet. It is refractory-lined and has an outlet lock hopper. 


\section{CAPITAL COST ESTIMATE}

The capital cost estimate for the 24 tpd PDU and the associated form coke equipment is based on the conceptual design described previously. A detailed listing of the PDU equipment and details of the capital cost components is included in Appendix B. The cost estimate, which is summarized in Table III13, assumes construction on the site of the Illinois Coal Development Park in Carterville, Illinois operated by Southern Illinois University, Carbondale, Illinois. It also reflects the preliminary facility layout illustrated in Figures III-12 and III-13. The illustrative major equipment elevations are shown in Figure III-14.

A high bay facility is available at the site, together with an extensive laboratory and personnel-related facilities. For this reason, only a nominal allowance has been made in the estimate for support facilities. The exact utilization of these existing facilities and the need for supplementing them will be determined during detailed disign. It appears at this time that the major PDU equipment will be locater in a separate structure from the high bay building, but that its controls and laboratory support facilities may be housed within the existing building.

Assuming that the PDU facility will be retained for use at the Illinois Coal Development Park beyond the proposed test period, no allowance has been included for demolition and site restoration. Nor has the scrap value of the equipment been considered in the cost estimate. Should demolition and site restoration be necessary the equipment scrap value has been estimated to totally offset the additional costs. No specific allowance has been included for unusual environmental permitting, although the allowance for engineering includes standard construction permitting.

The pricing of the majul equipment is based on Bechtel in-house data; the pricing for bulk materials are factored based on Bechtel in-house data for similar projects. Direct manual manhours are developed using Bechtel's standard unit manhours as determined by historical data. The composite wage rate for union labor is based on in-house data for the Chicago, Illinois, area. Costs are expressed in lst quarter 1991 dollars with no escalation. 
Table III-13. 24 tpd PDU ESTIMATED CAPITAL COST (lst Quarter $199110^{6}$ s)

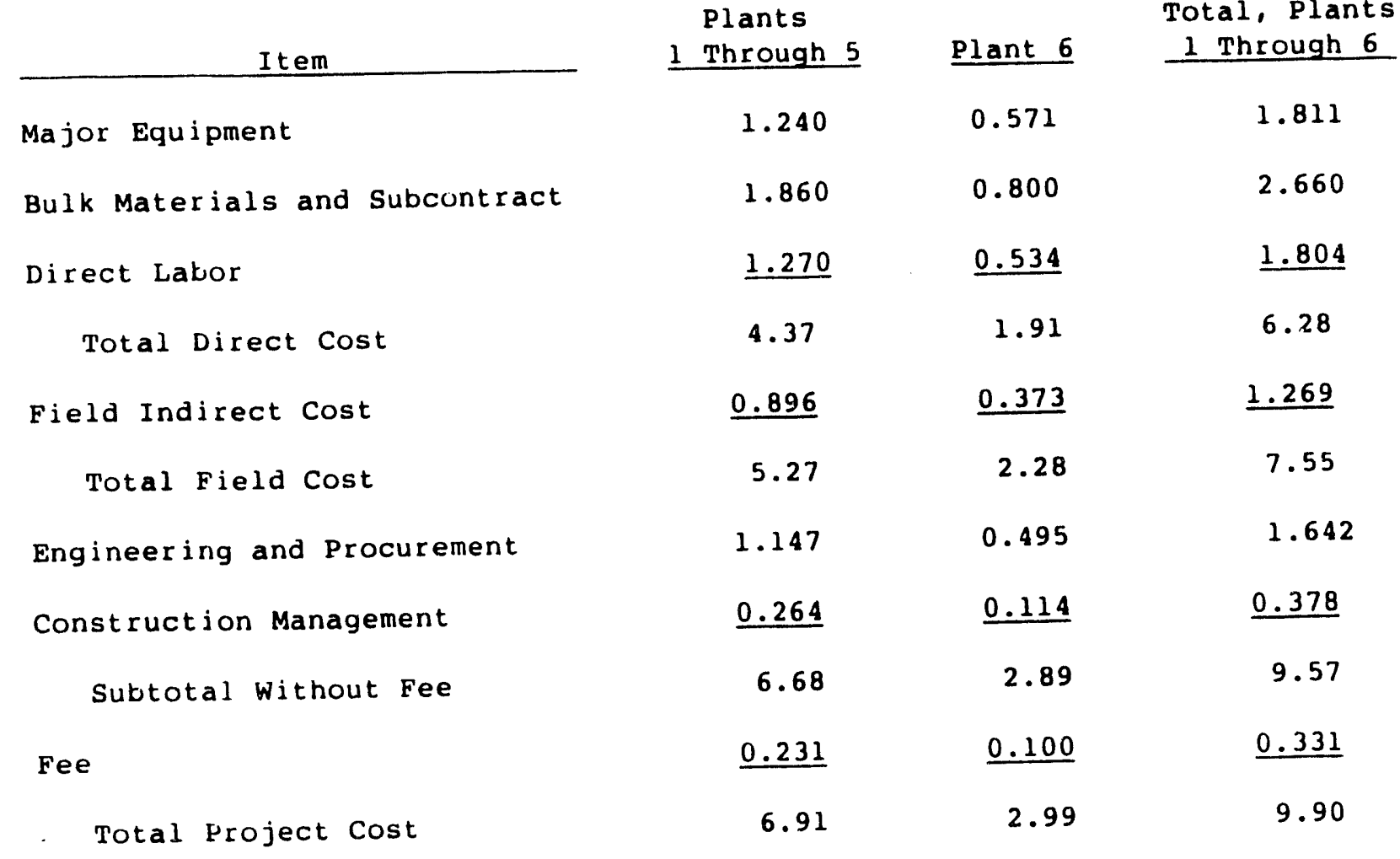




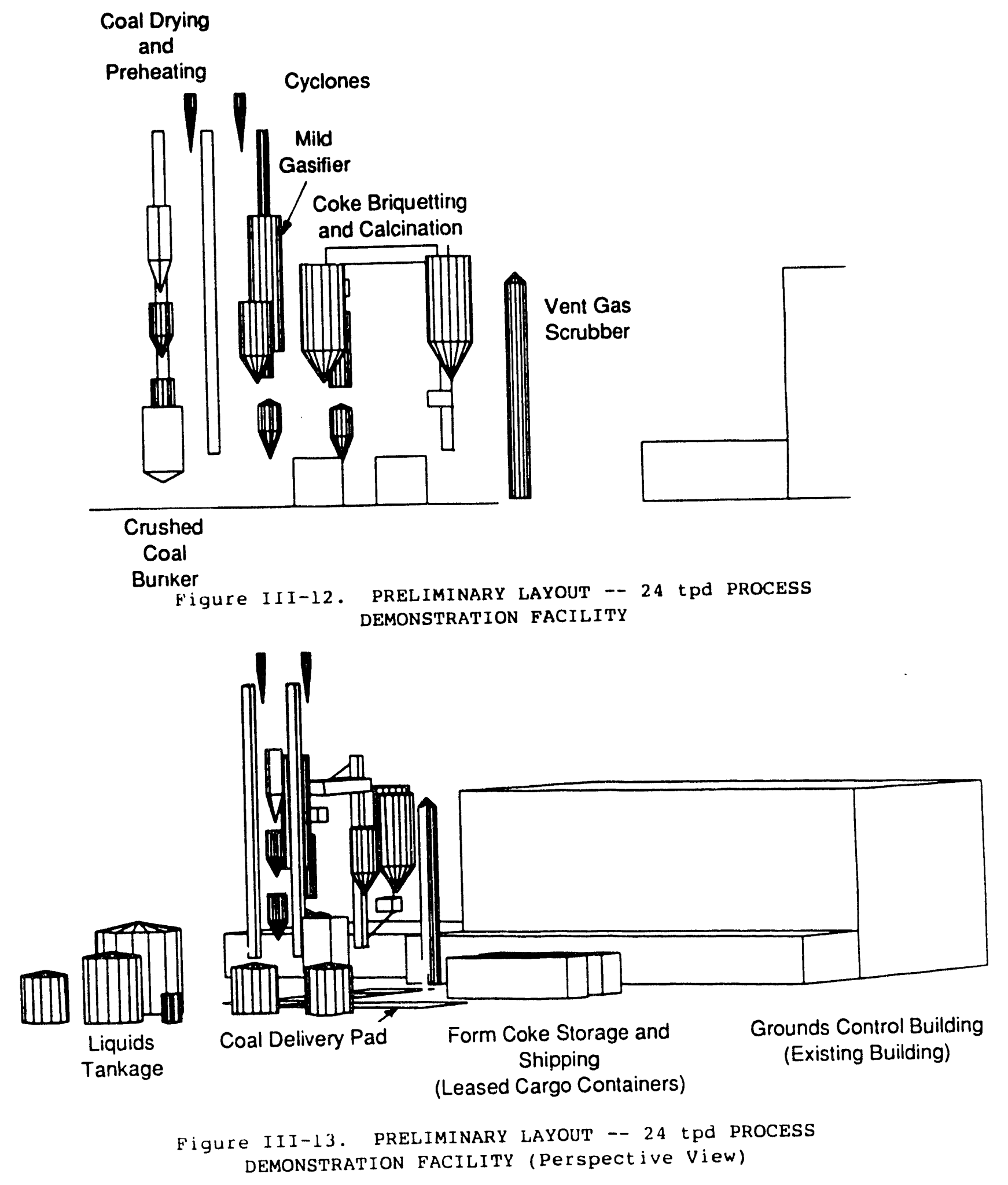




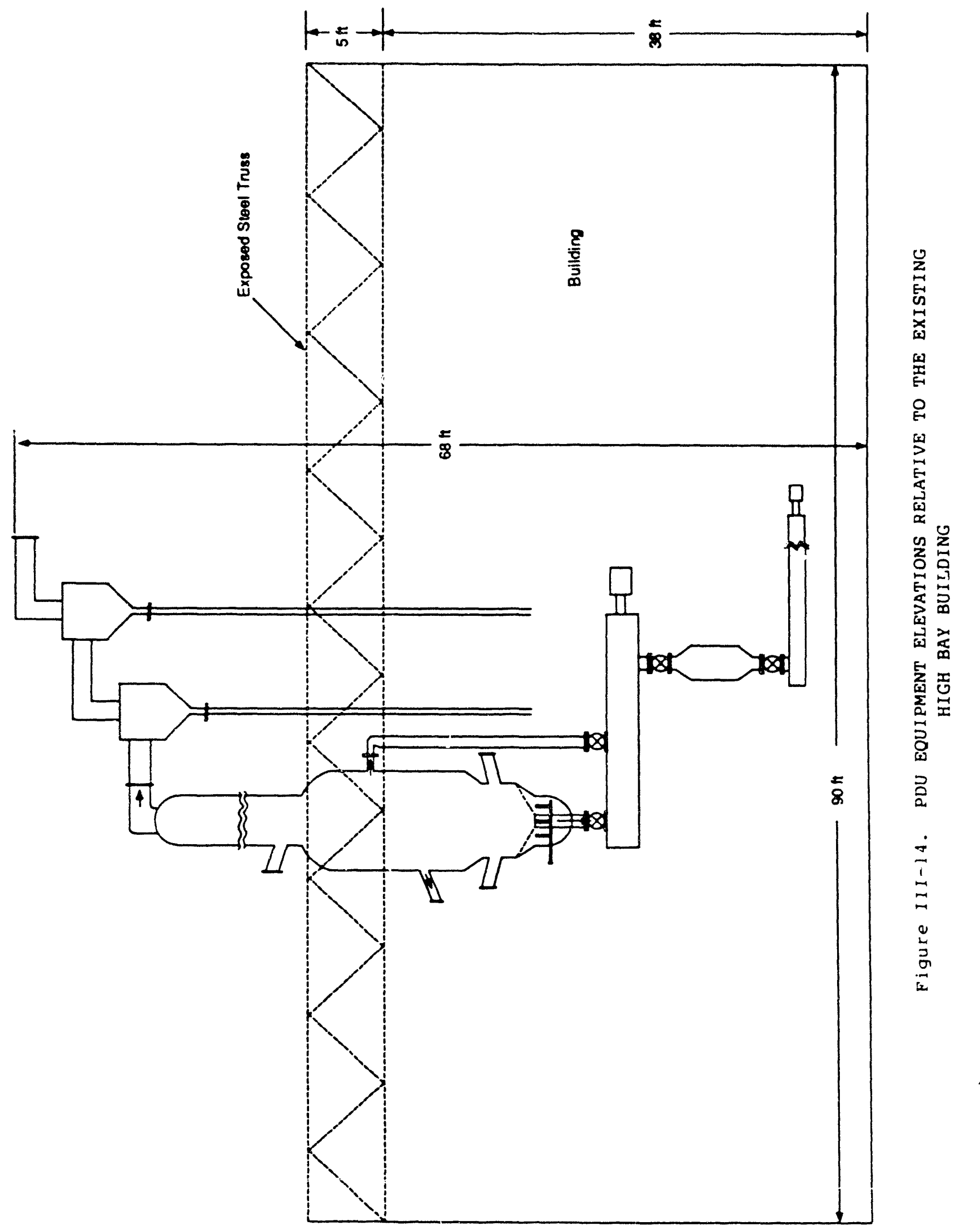

III -68 


\section{OPERATING COST ESTIMATE}

The following estimate of the PDU operating costs envisions a 12-month periud of operation followed by a 2-month period for mechanical inspection of the unit and data evaluation and documentation. The 12-month operating period consists of 2 months for startup and shakedown followed by 10 months of intensive parametric testing employing a variety of coals.

Operations Staff Requirements

The estimated staffing requirements for the operation are defined in Table III-14. As indicated, a 5 day/wk operation is assumed, with 3 shifts operating per day (24 hours). With allowance for postoperation inspection, data assessment, and offsite analytical support, the total labor requirement is about 23,000 manhours.

\section{Test Program Operating Cost}

The estimated cost for the 12-month operating program and 3-month period for data analysis and documentation is presented in Table III-15. The total cost of $\$ 2.9 \mathrm{milli}$ ion reflects an estimate of fully overheaded staff salaries and includes an allowance for travel and subsistence for IGT/Bechtel technical support during the startup and during postoperation inspection. 


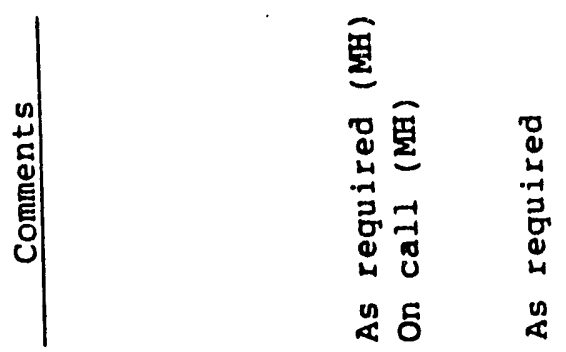

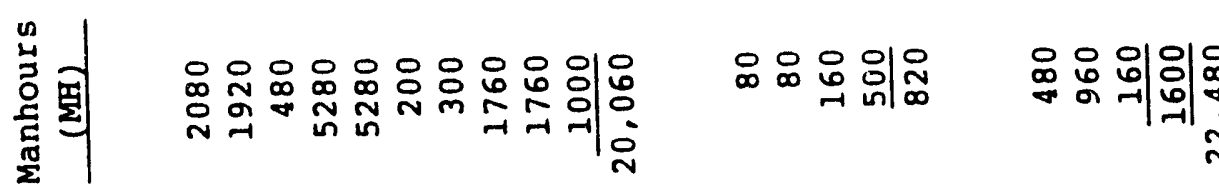

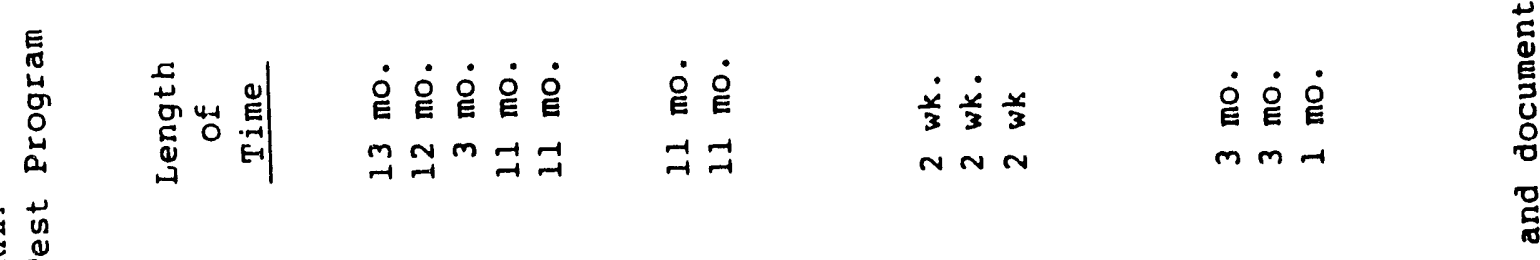

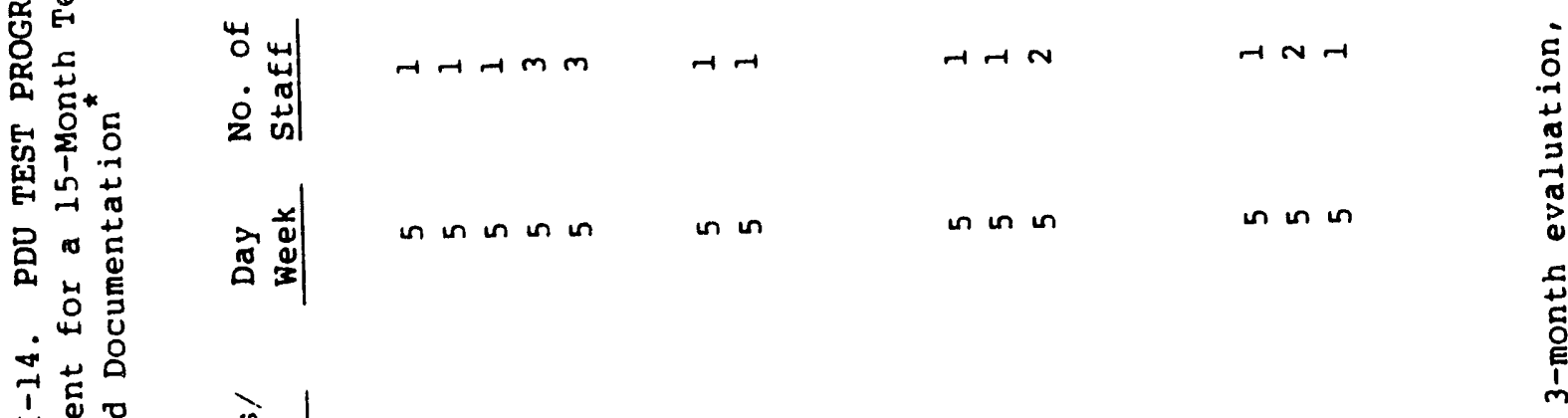

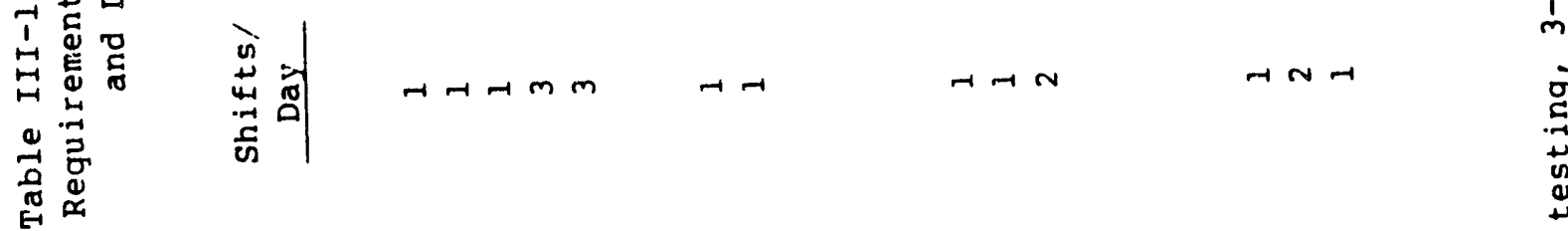
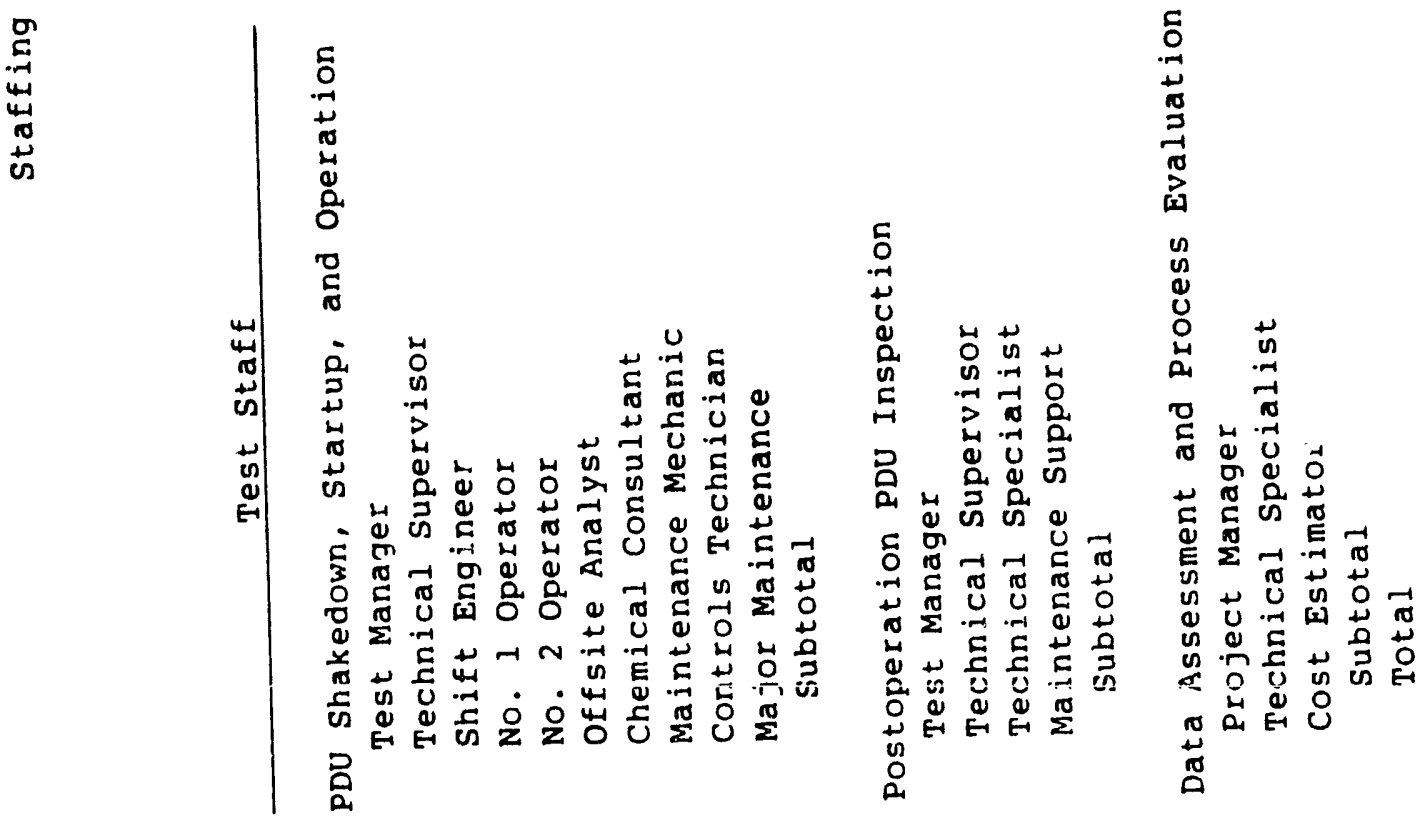

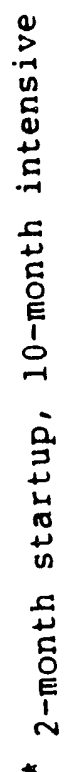




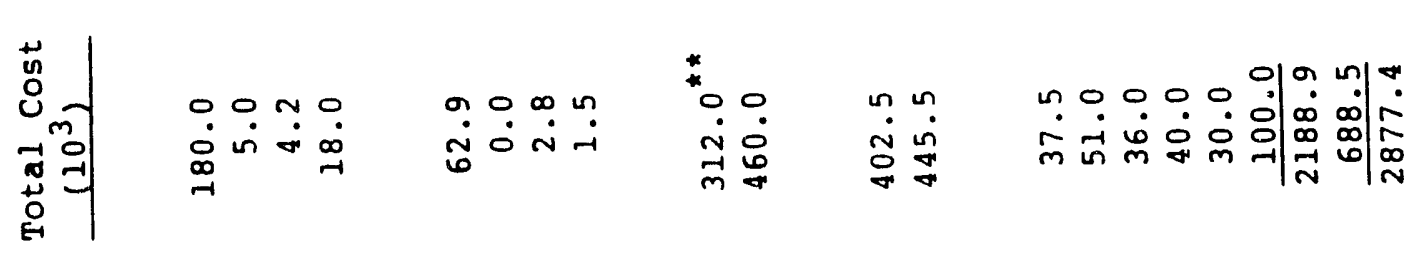

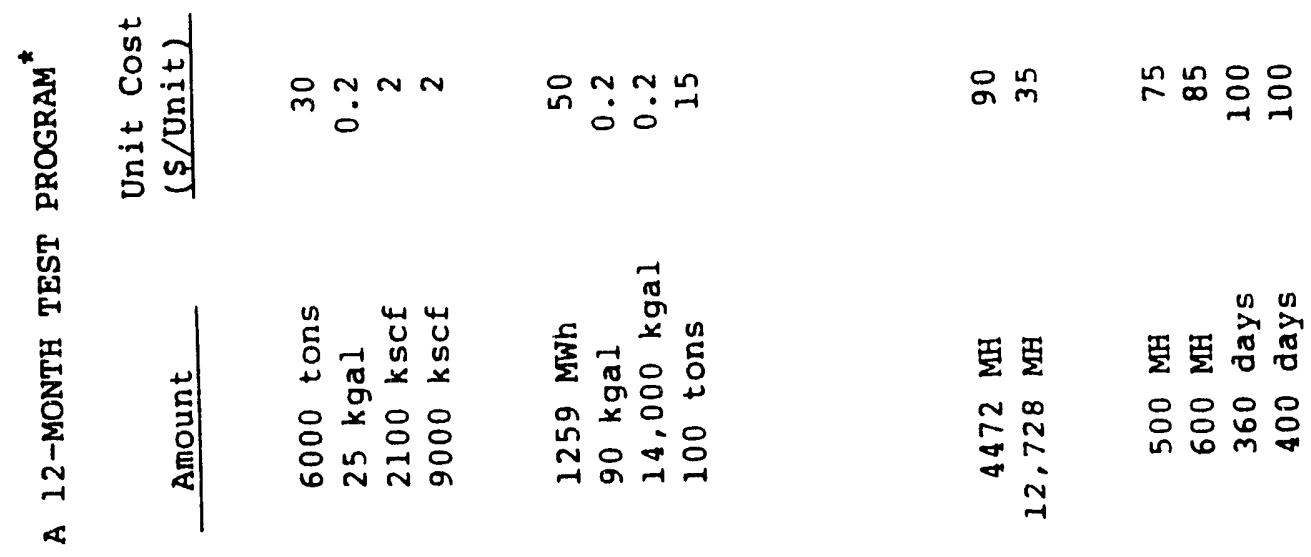
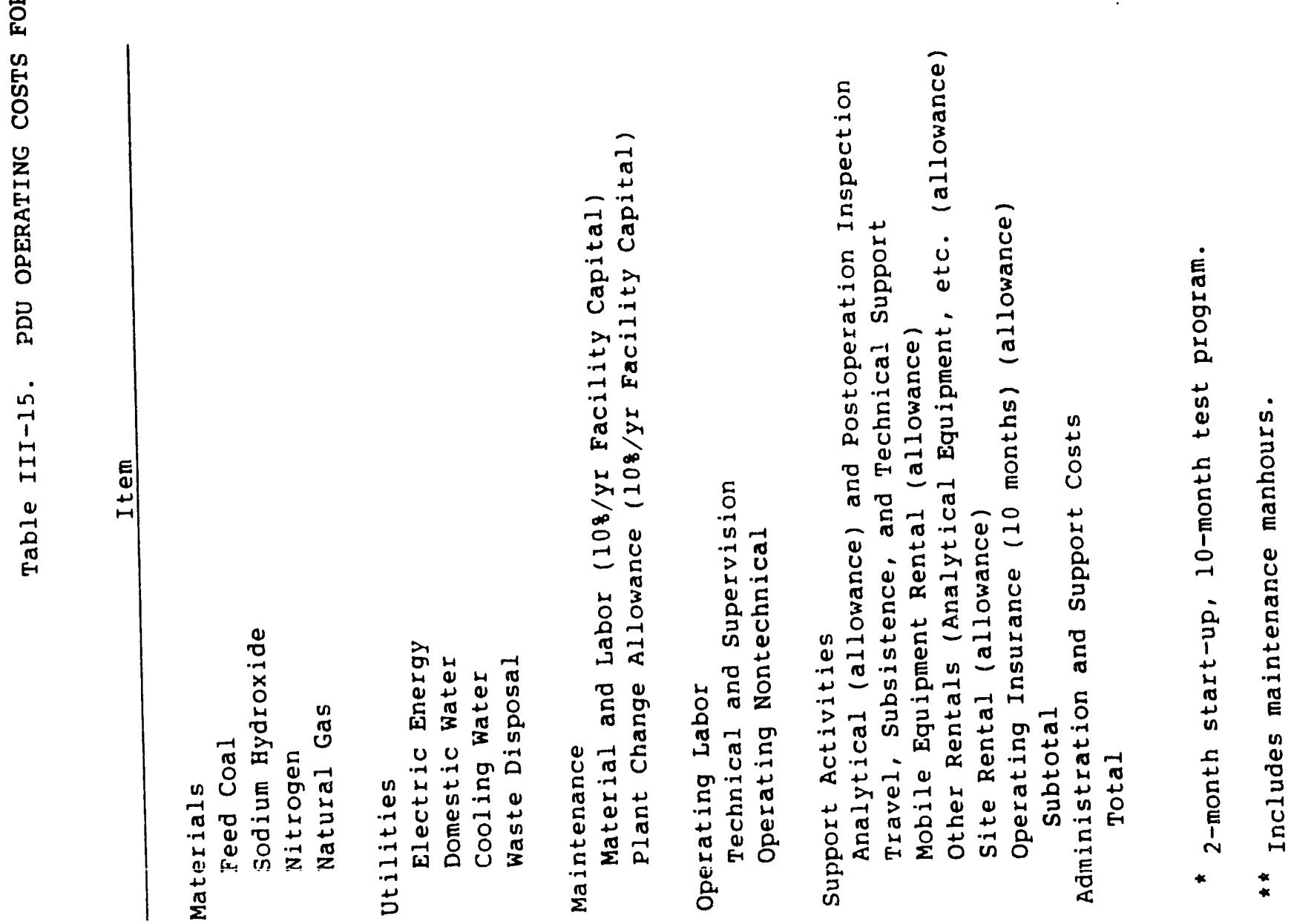
DETAILED EN TNFERING

Preliminary piping and instrumentaiion diagrams (P\&IDs) and electrical single-line diagrams for the 24 tpd process development unit are described in this section. The drawing package is included in Appendix $\mathrm{C}$.

The P\&IDs and electrical drawings provide an added level of detail to the gasification and form coke production units. These drawings are preliminary in nature and should not be used for construction purposes. Additional sitespecific information required for bringing these drawings to the level of detail required for final engineering is also discussed.

\section{piping and Instrumentation Diagrams}

Preliminary P\&IDs were prepared to further detail the schematic representation of the piping, ductwork, material flow, process control, and instrumentation for the mechanical systems of the process. The process equipment is generally grouped by function. The groupings are also made with the intent to facilitate layout and grouping of equipment according to area electrical classification requirements.

Development and review of the preliminary P\&ID drawing package also provided an added level of review of the proposed process configuration. This resulted in a number of recommendations to improve unit operations and/or reduce costs. A summary of these recommendations are given in Appendix $D$. The preliminary P\&IDs included in Appendix $C$ are listed in Table III-16. Table III-16 gives the preliminary hazardous area classification designations for the equipment shown in the drawing. The Class I areas shown above can be further defined as Class $I$, Division 2 , indicating that equipment in the area handles combustible vapors in sealed, inert-blanketed, vessels such that the vapors are not normally present in air. Class II areas shown can also be further defined as, Division I, Group F, which indicates that the area is exposed to coal or coke dusts which may be present in combustible concentrations in the atmosphere. Equipment in use in areas with both area classification designations must satisfy the requirements of both classifications (i.e., equipment must be both explosion-proof (Class I) and dust-tight (Class II). 
Table III-16. PRELIMINARY P\&IDS

\begin{tabular}{|c|c|}
\hline No. & Description \\
\hline$A-00$ & Symbols and Legend \\
\hline$A-01$ & Coal Handling \\
\hline$A-02$ & Coal Drying \\
\hline$A-03$ & Gasifier Heat Supply \\
\hline$A-04$ & Gasifier \\
\hline$A-05$ & Hot Gas Fines Removal \\
\hline$A-06$ & Heavy Oil/Tar Recovery \\
\hline$A-07$ & Middle and Light Oil Recovery \\
\hline$A-08$ & Incinerator \\
\hline$A-09$ & Emission Control \\
\hline$A-10$ & Chemical and Solution storage and Handling \\
\hline$A-11$ & Coal oil Products storage and Handling \\
\hline$A-12$ & Char and Coal storage and Handing \\
\hline$A-13$ & Briquette Forming \\
\hline$A-14$ & Briquette Calcining \\
\hline$A-15$ & Calciner Air and Heat Supply \\
\hline$A-16$ & Process Utilities \\
\hline
\end{tabular}

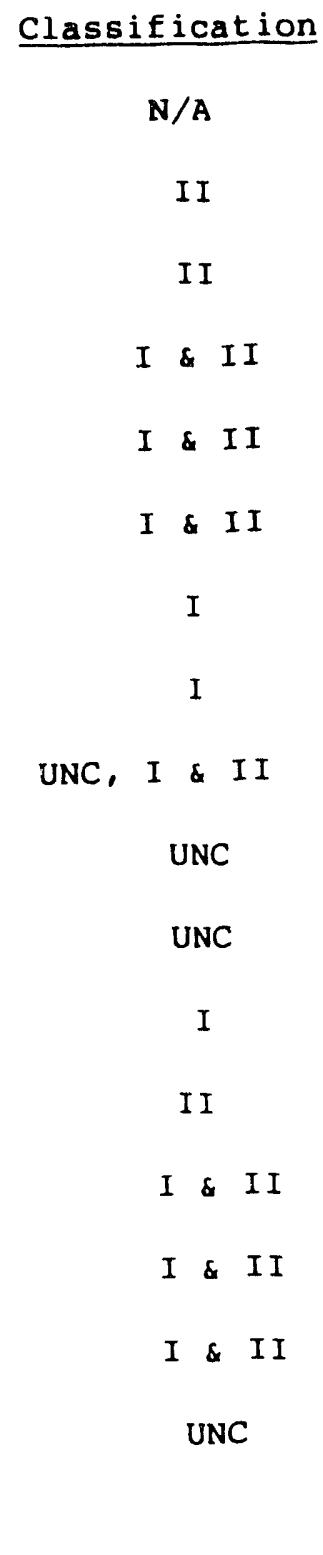


A determination of the specific classification area requirement will require an equipment layout adequate to identify the location of the equipment items and establish the boundaries of the classified areas. This design will be performed to minimize the equipment procurement and installation costs, and to simplify PDU operation requirements.

\section{Electrical single-Line Diagram}

An electrical single-line diagram, Drawing E-01, was also developed and is included in the drawing package, Appendix $C$. This drawing shows all of the electrical loads of the PDU unit, including all utility requirements. The drawing is also preliminary in nature. Power distribution may be significantly altered if skid-mounted units or other types of materialhandling equipment are selected during final design (e.g.. venturi feeders instead of rotary air lock valves or pneumatic pumps instead of electricmotor-driven pumps).

The electrical loads shown in Drawing E-01 permit the electrical feeder requirements to be estimated. The PDU electrical system has a total connected load of $431 \mathrm{kVA}$, and the projected power demand is estimated to be $393 \mathrm{kVA}$. This system, therefore, requires a single $480 \mathrm{Vac}, 3$-phase, 4-wire, $600 \mathrm{~A}$ feeder. This feeder will allow for about $20 \mathrm{hp}$ in future load growth without having to discount demand based on load duty or make other provisions for electrical power.

Electrical schematics, control logic, wiring diagrams, and other electrical details will be developed during final design.

\section{Additional Information Required for Final Engineering}

At this level of design, several question arise which must be resolved before a final engineering package can be produced. Final engineering for construction will require the following:

Verification of site resources and availability of:

-- Utilities

- Buildings and personnel facility

- Preferred siting and access for the PDU, with special attention to truck access and routing

- Soil characteristics 
- Selection of mechanical equipment accompanied by process adjustment to match the equipment requirements

- Coordination with the proposed operations staff to accommodate its specific test program and operating preferences

- Design adjustment to support and accommodate special environmental permitting requirements

- Screening of DOE surplus equipment for possible use on the project 
APPENDIX A. Material Balances for Two Alternative Hot Char Recycle Rates

I I I $-A-1$ 


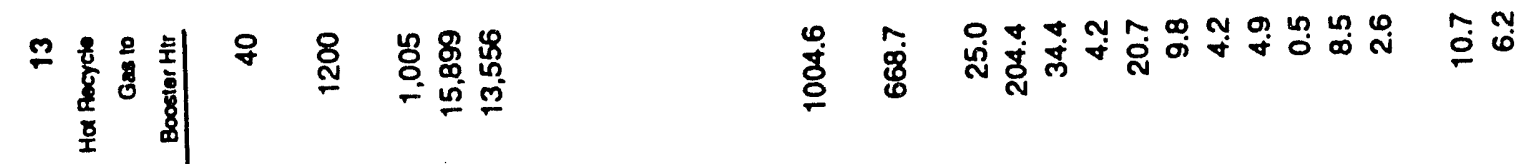

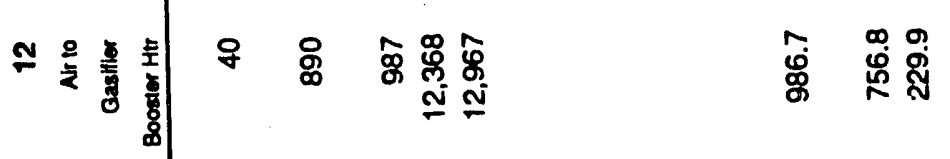

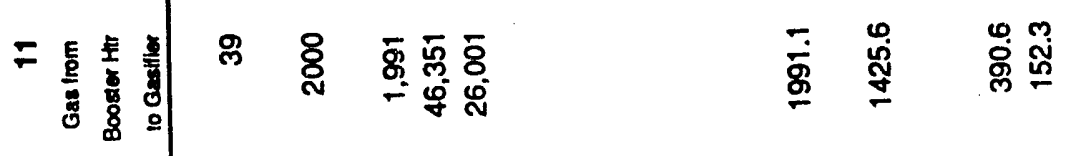

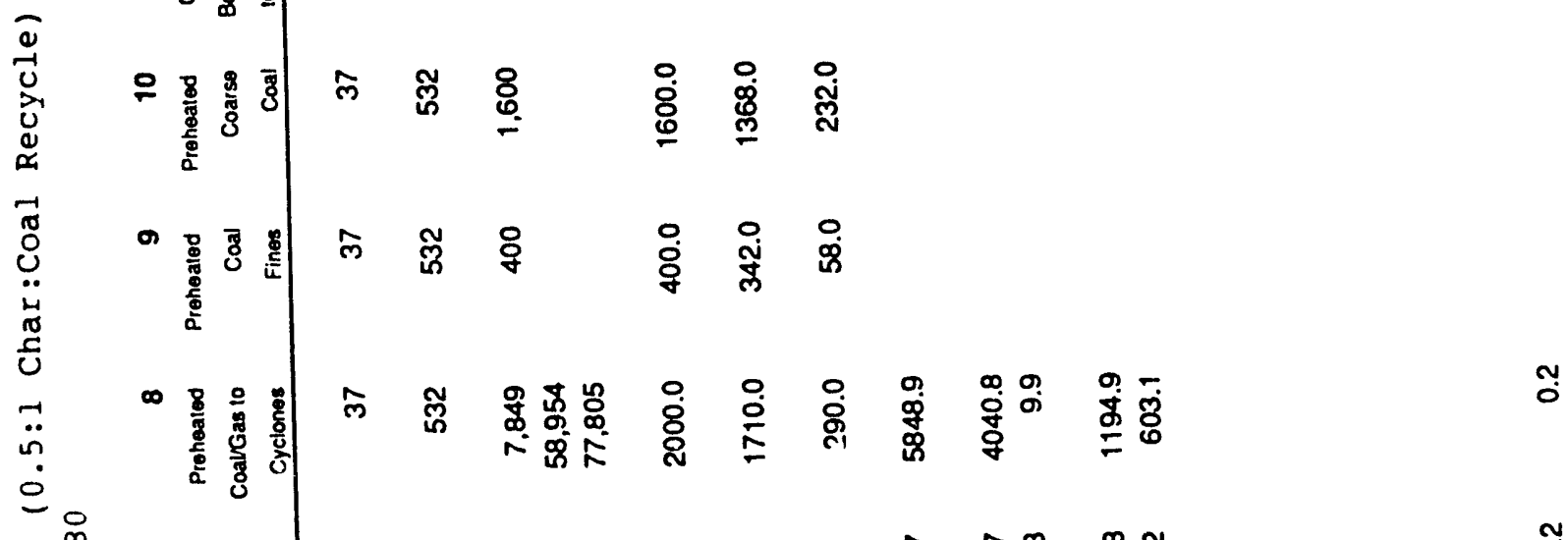

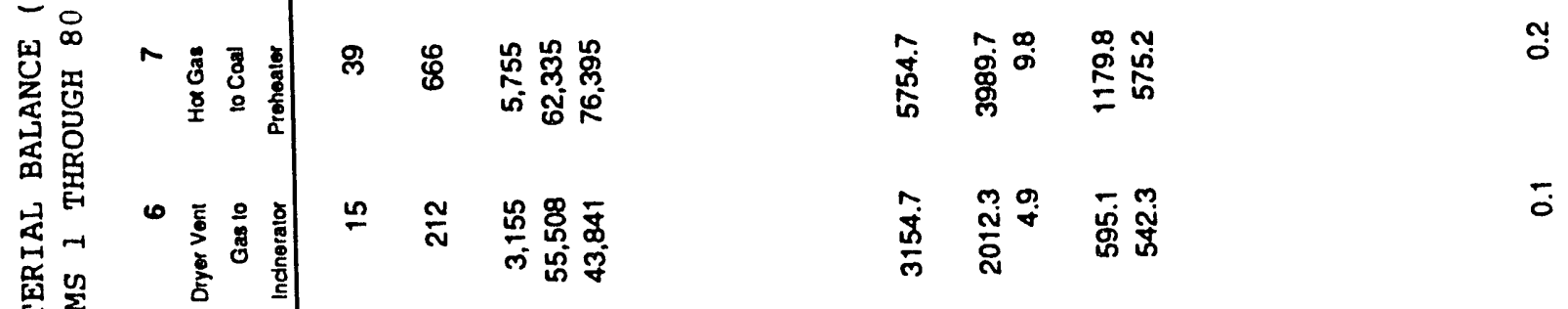

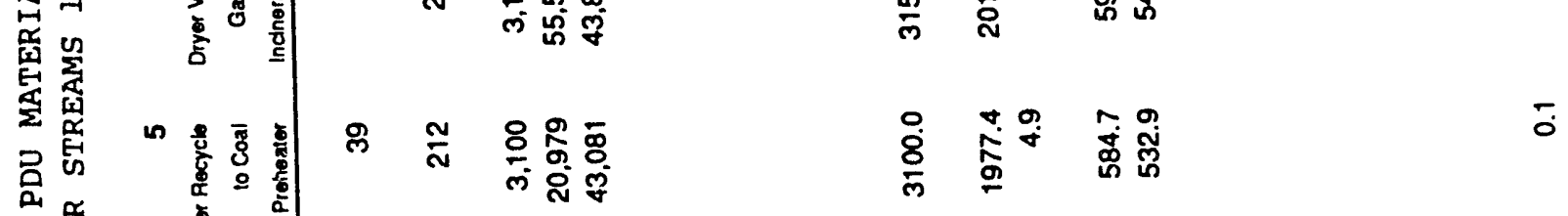

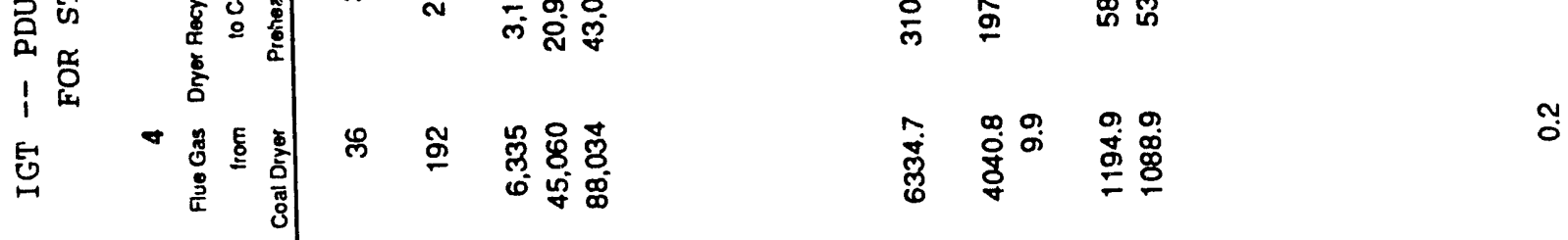

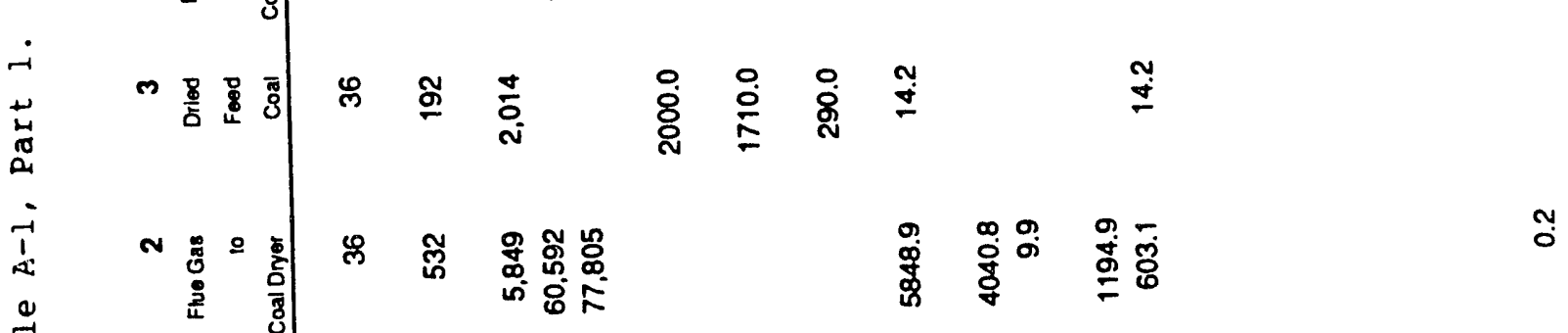

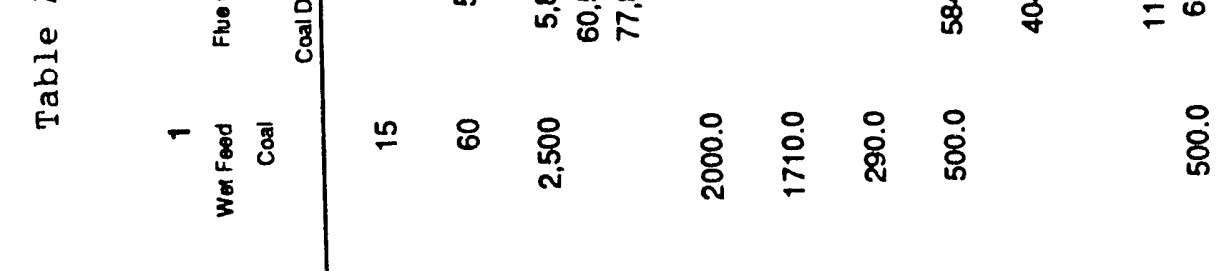

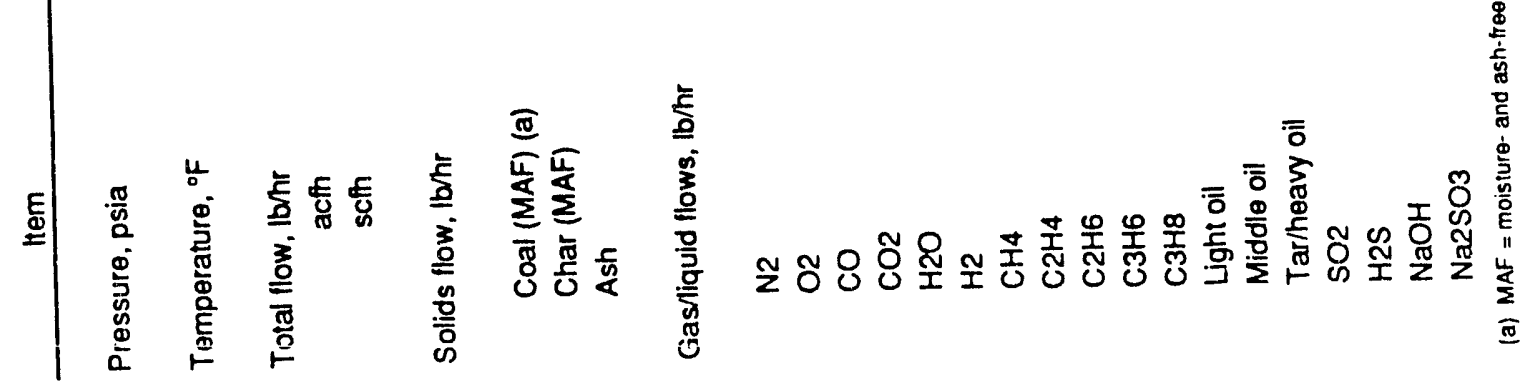

$$
\begin{aligned}
& \text { I I I }-A-3
\end{aligned}
$$




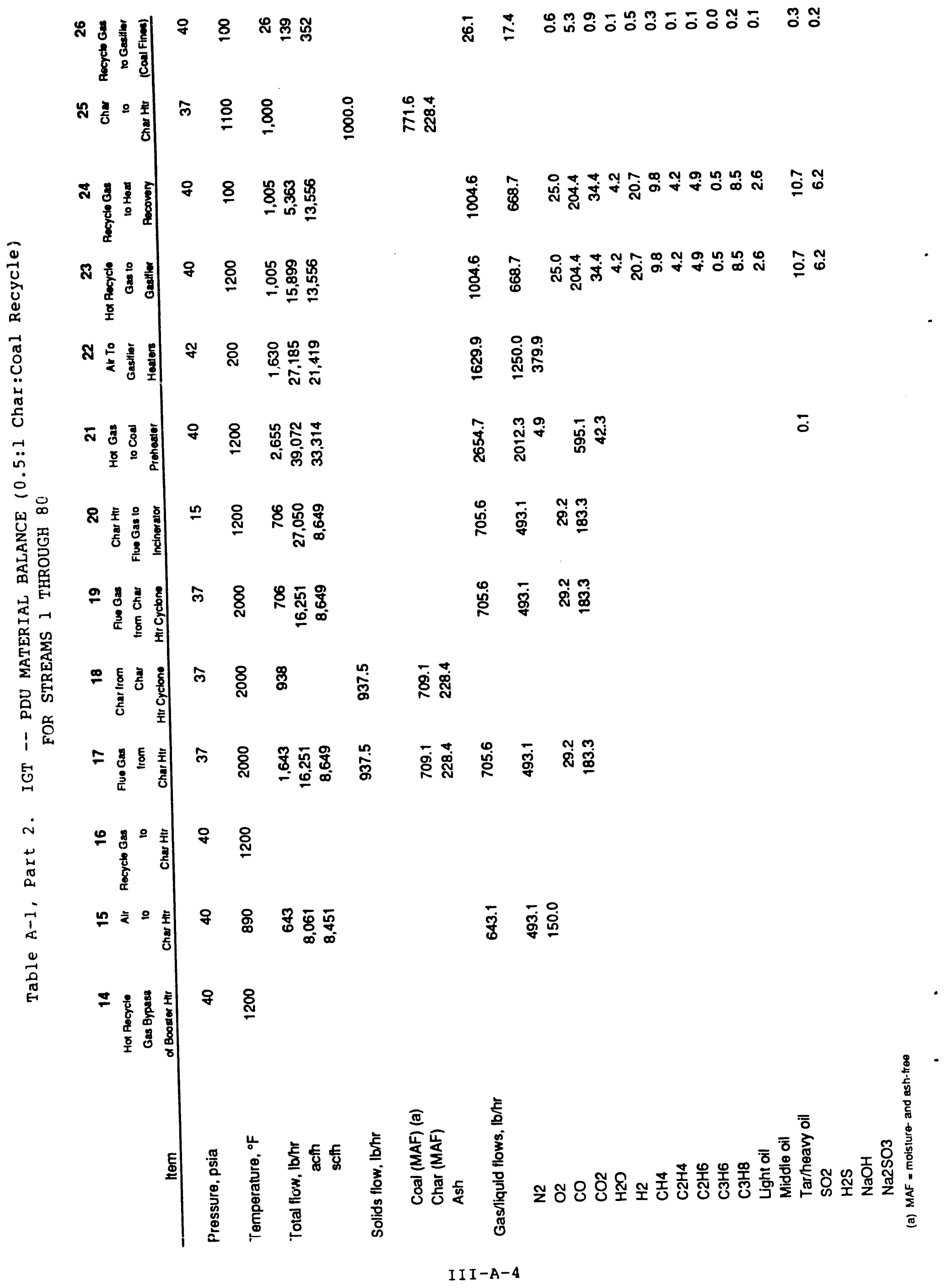




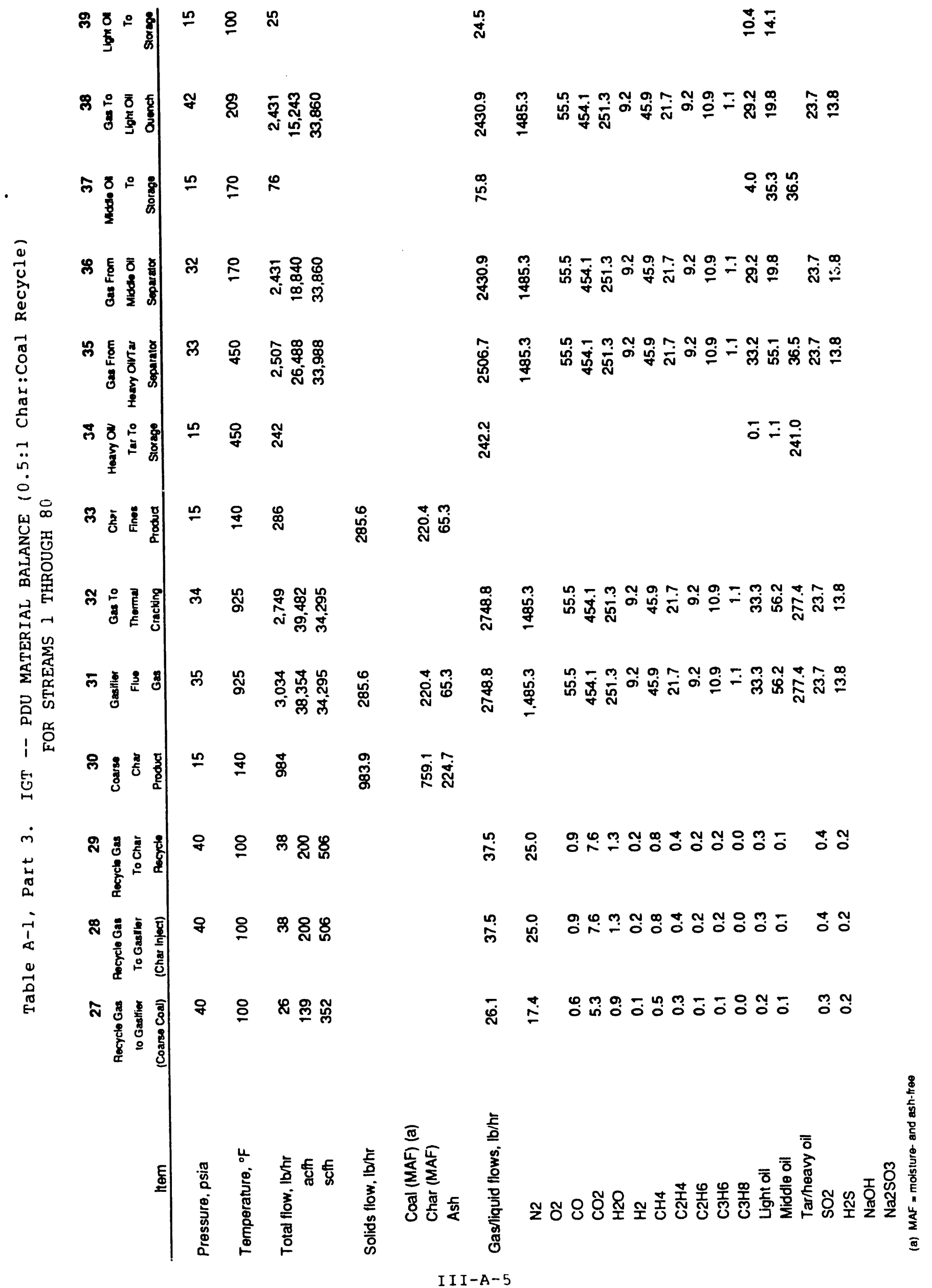




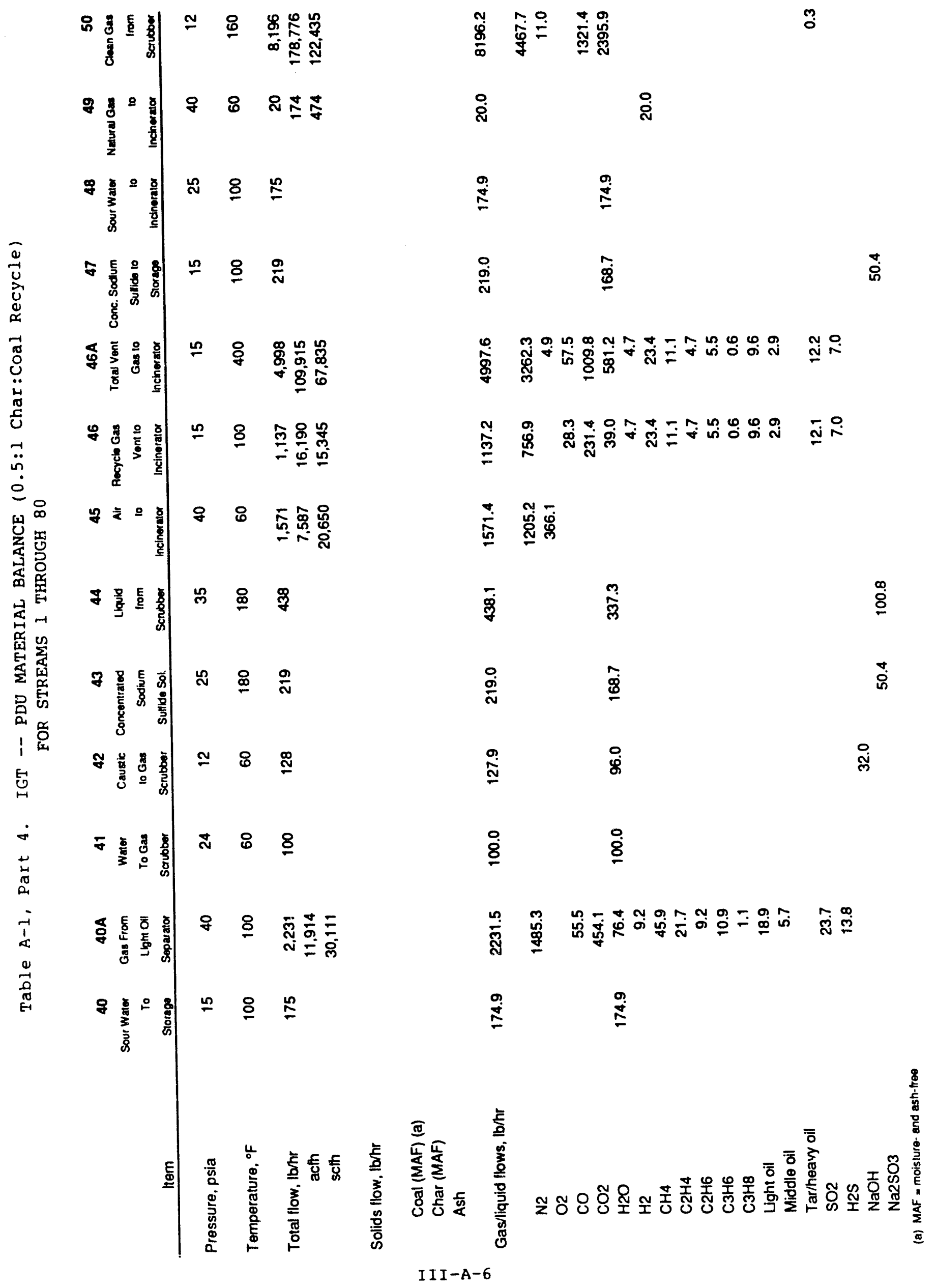




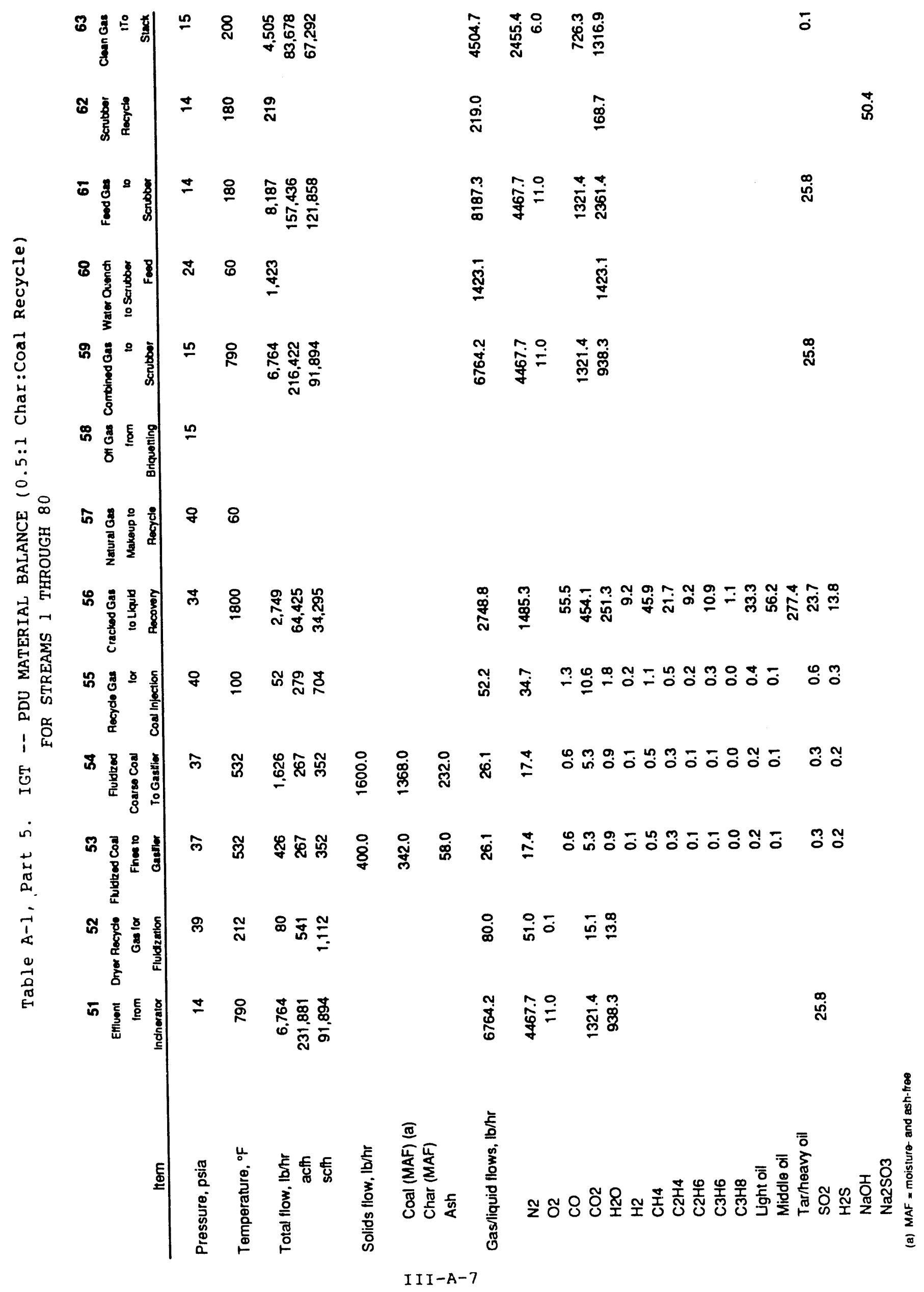




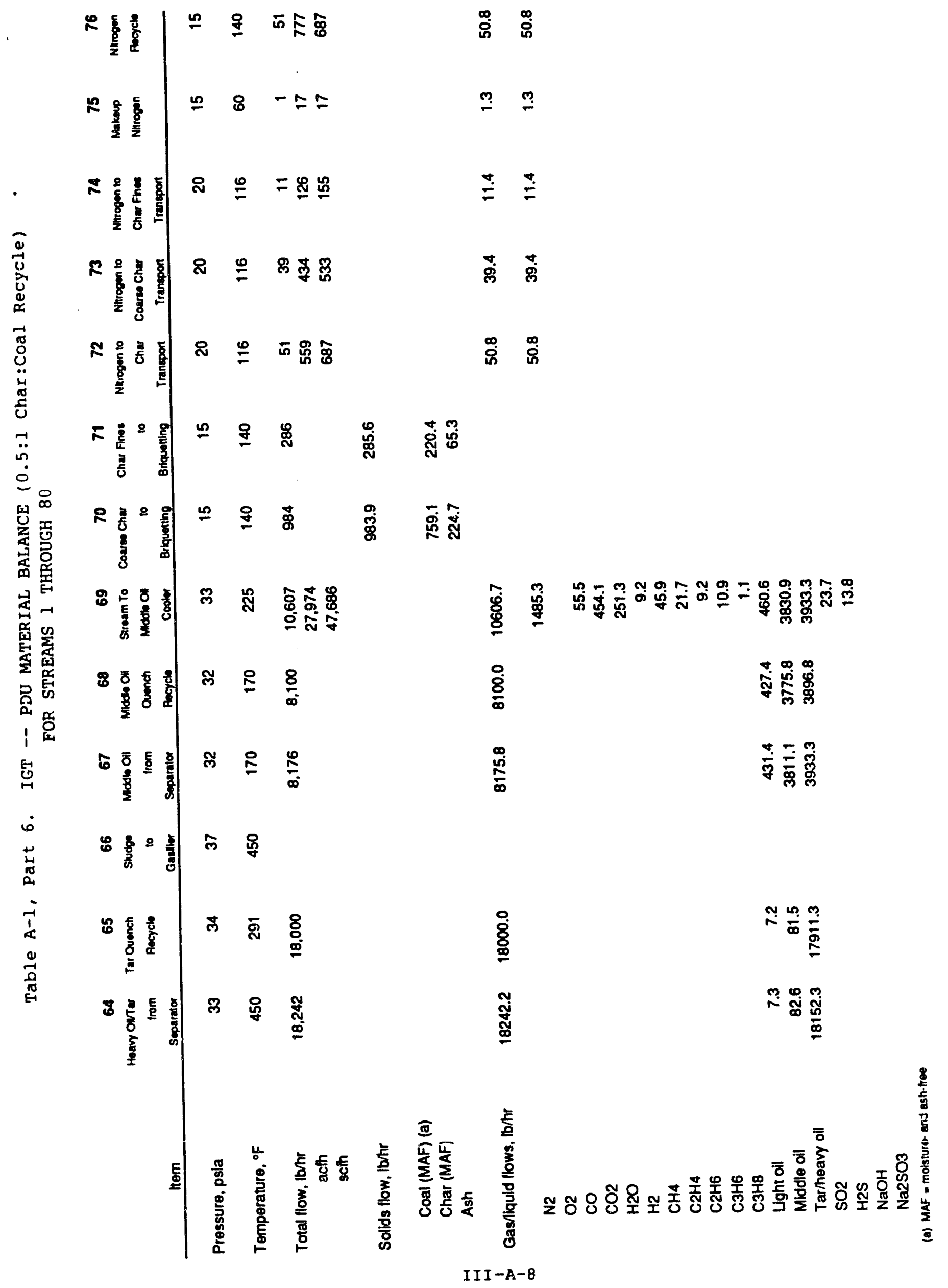




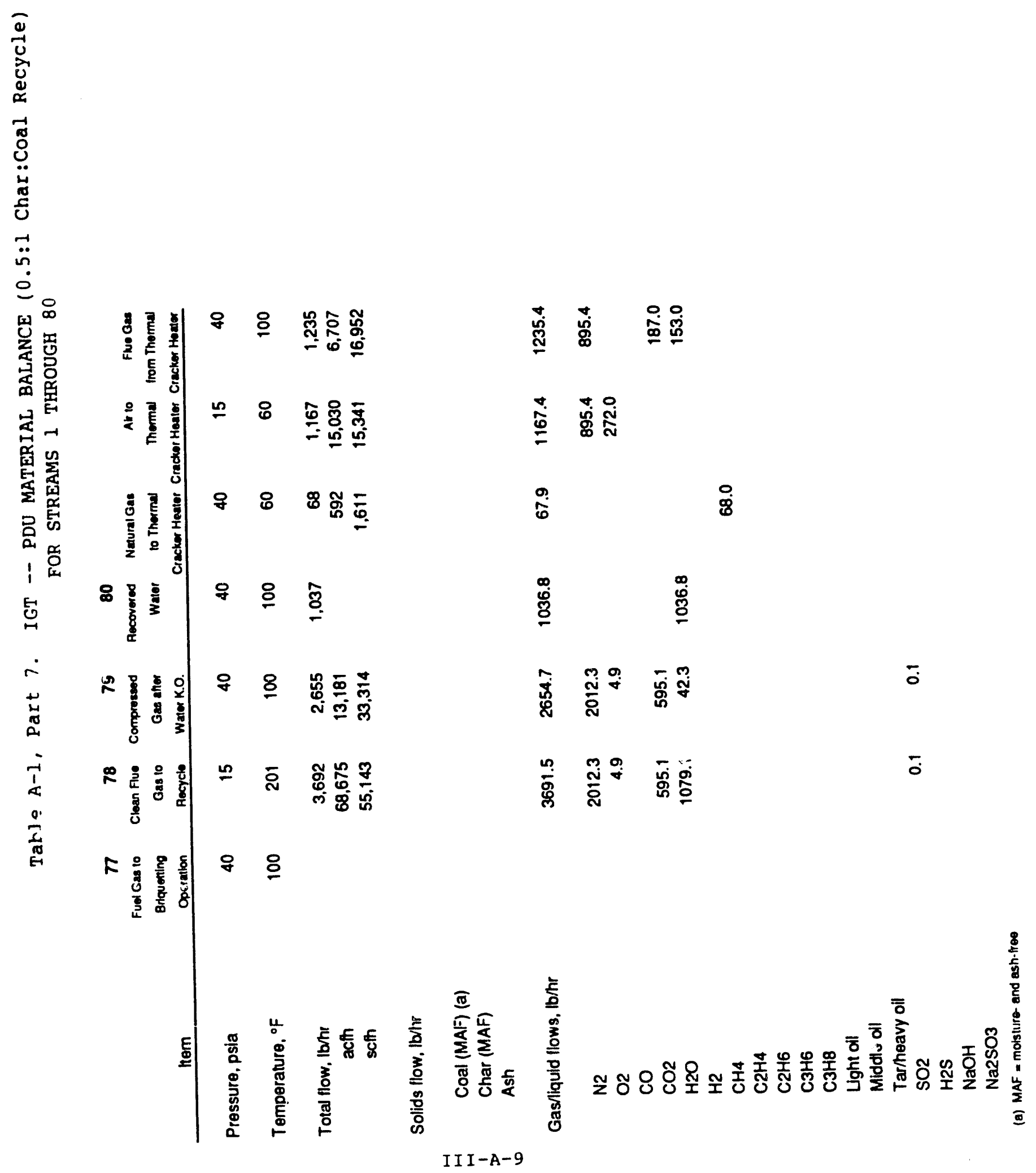




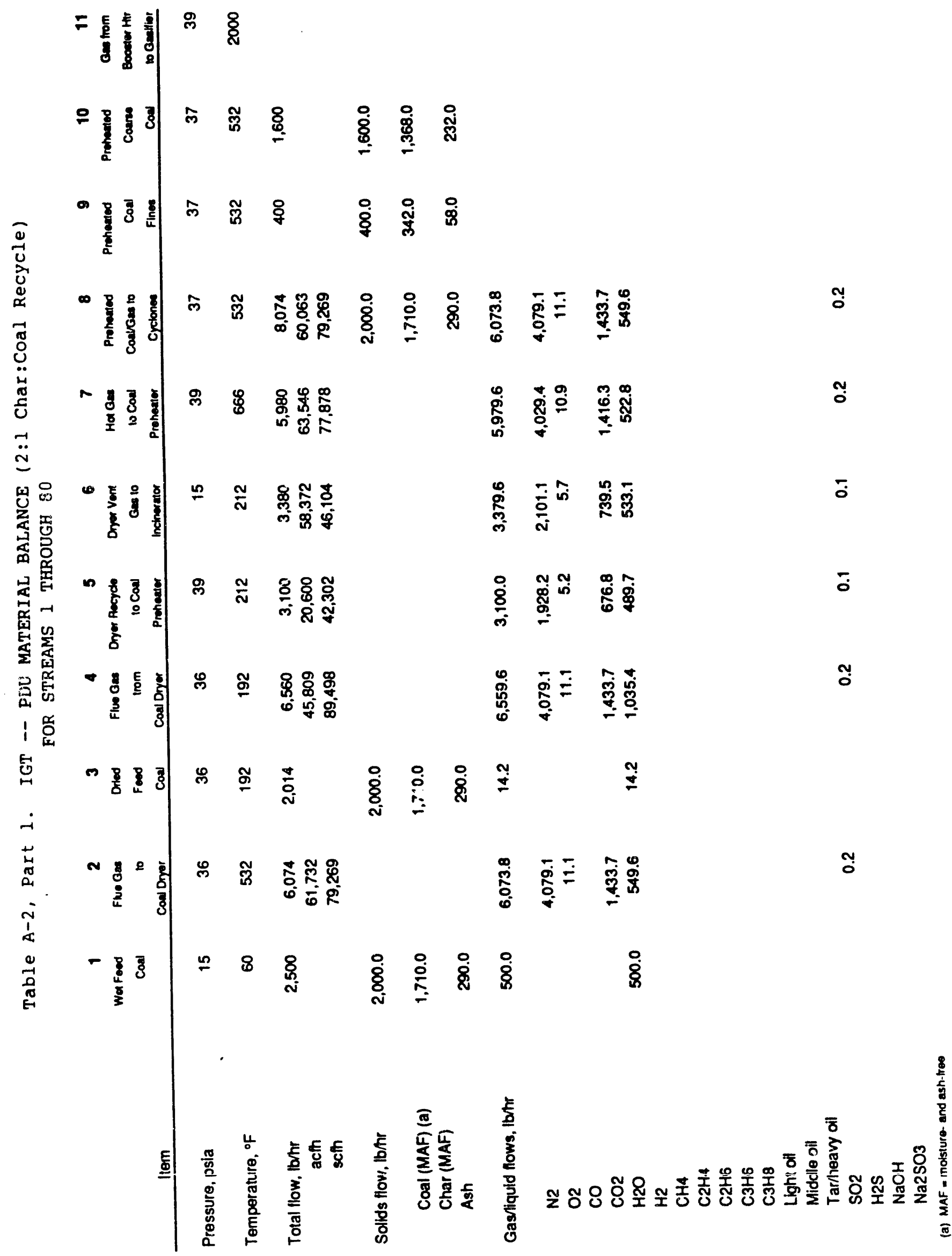




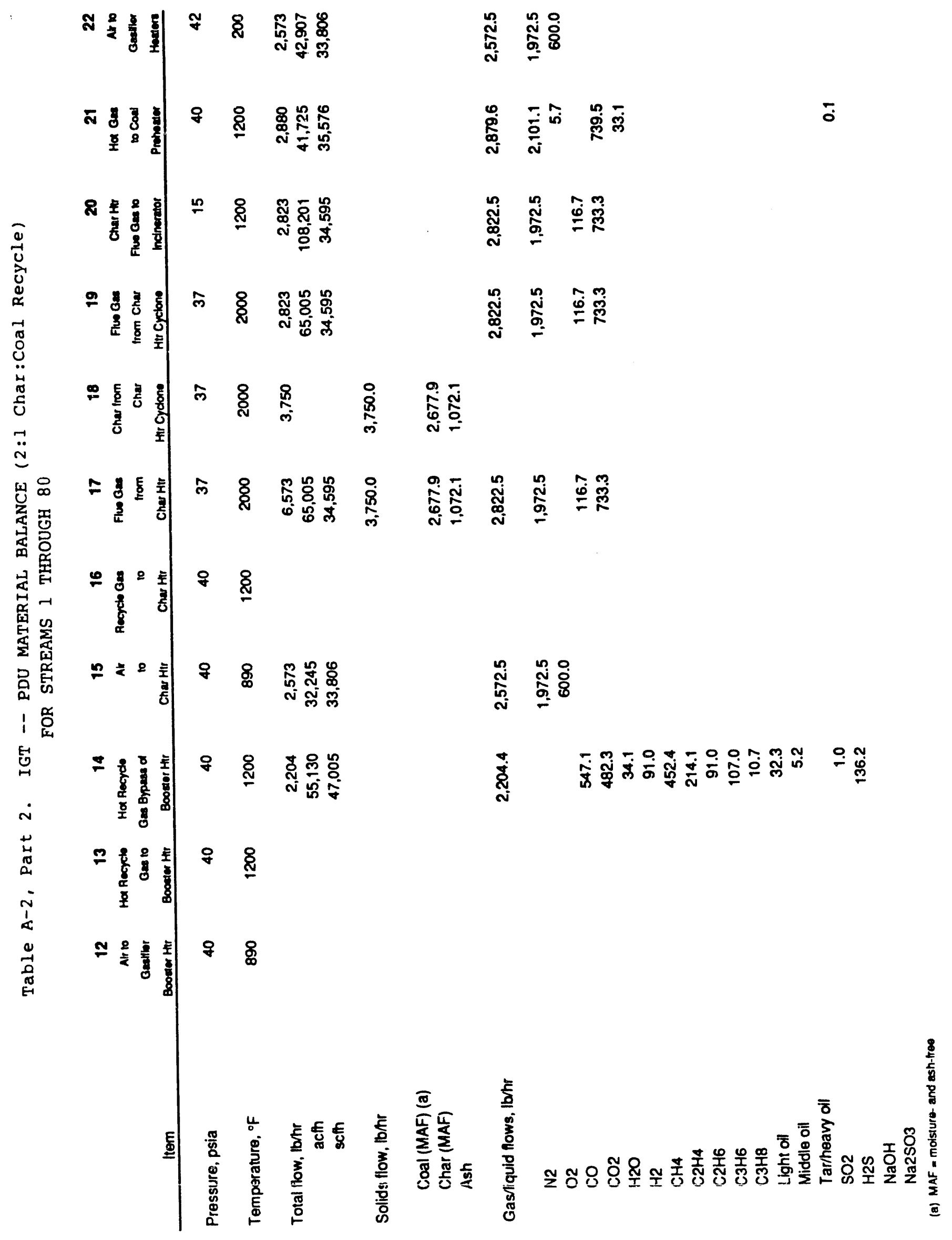




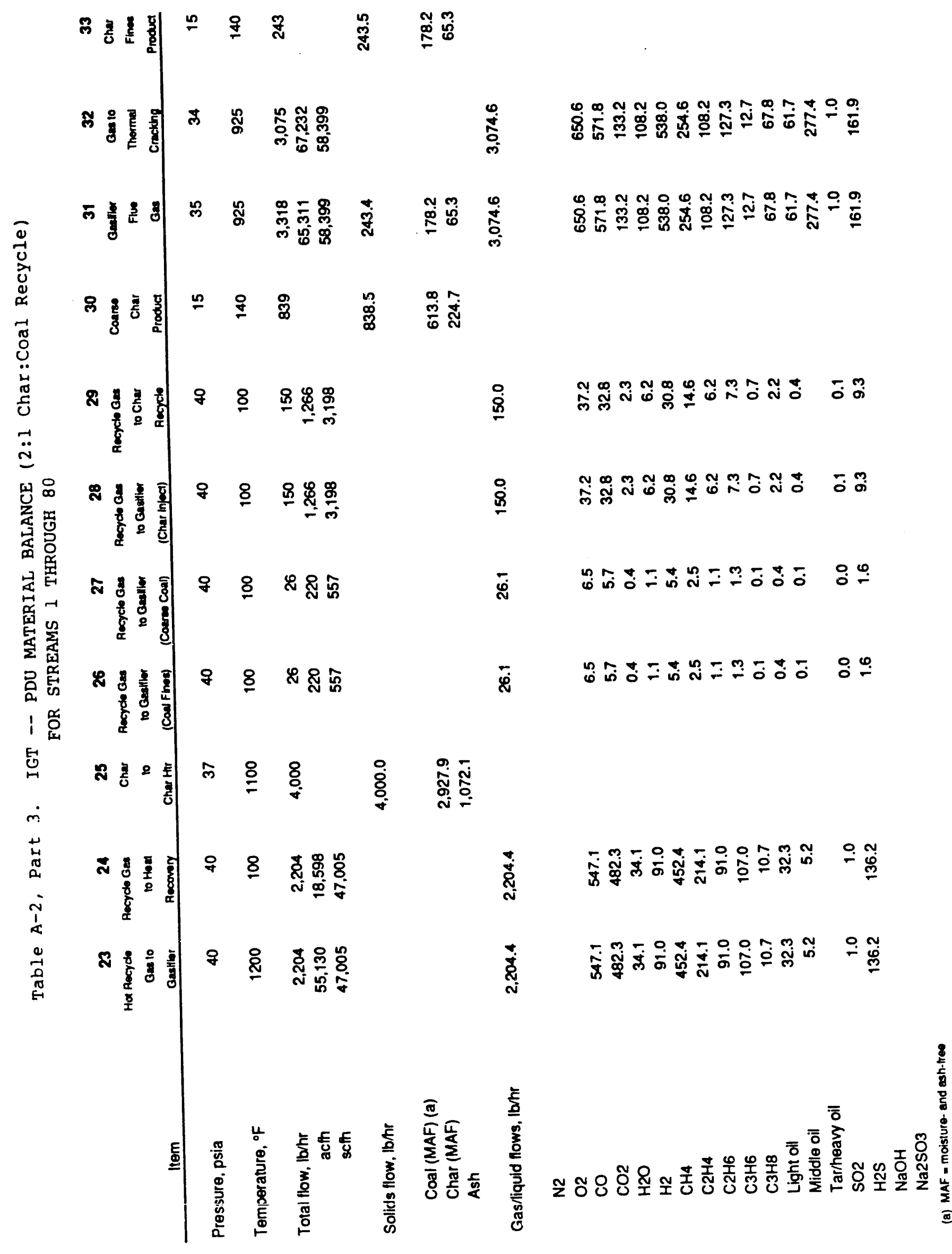




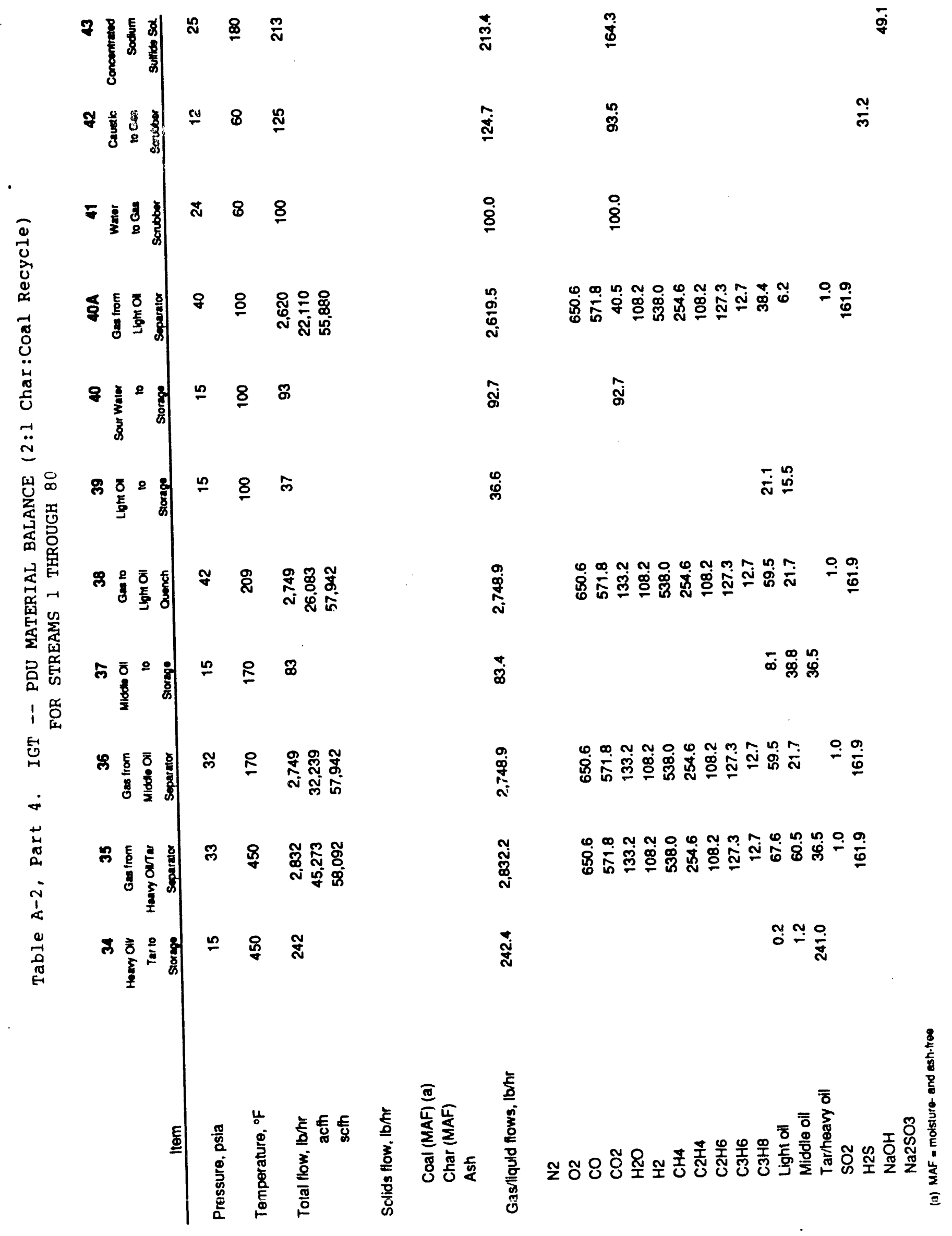




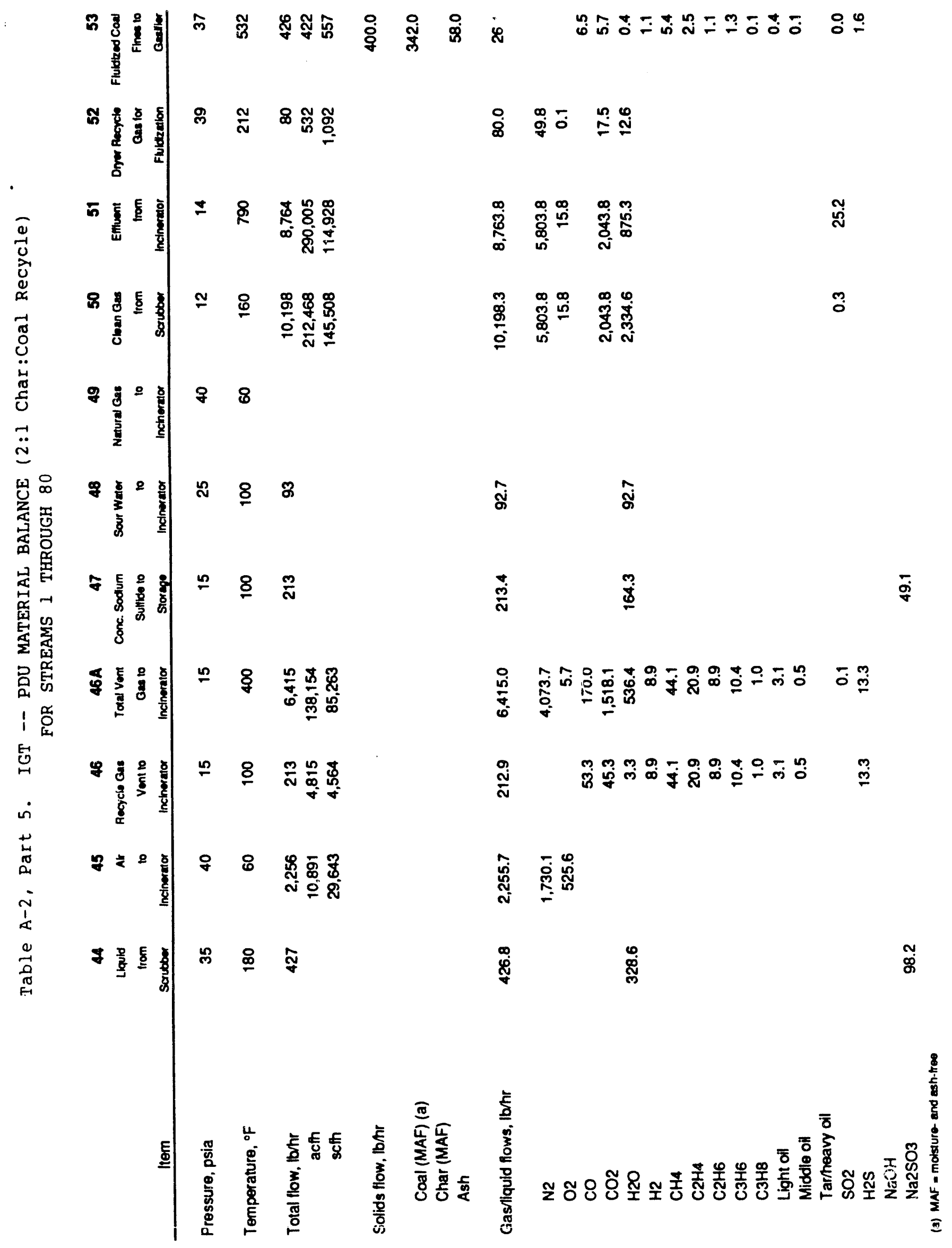




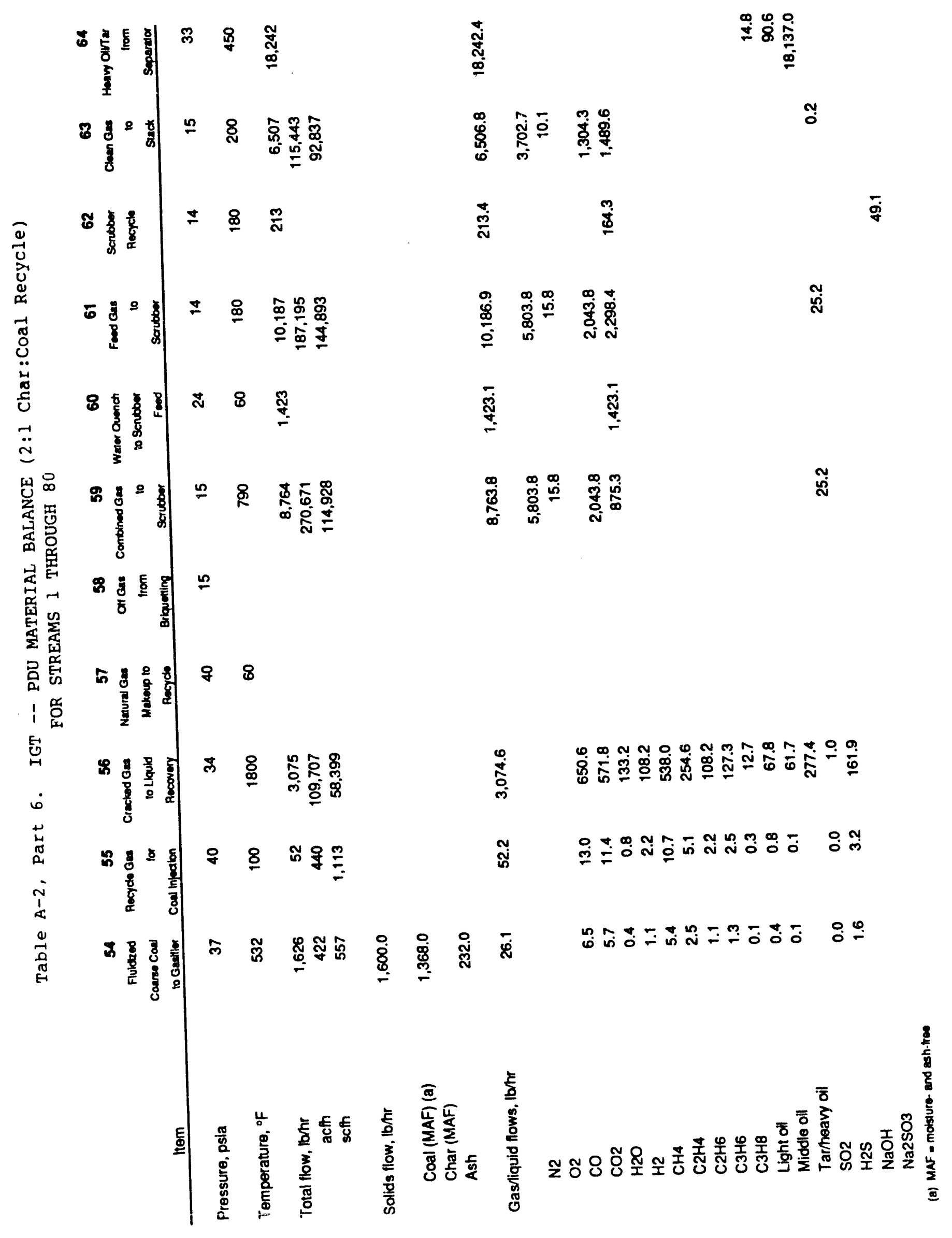




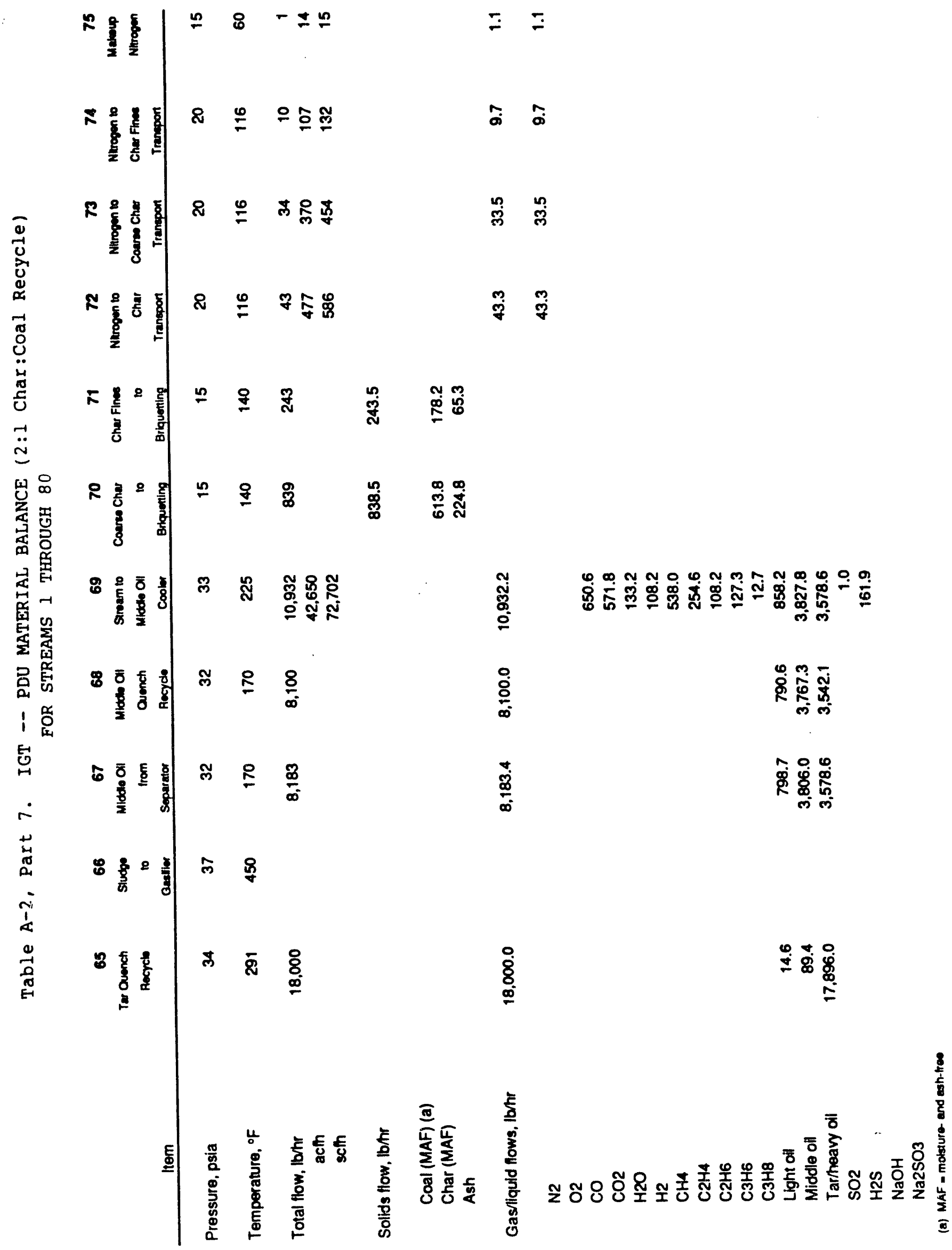




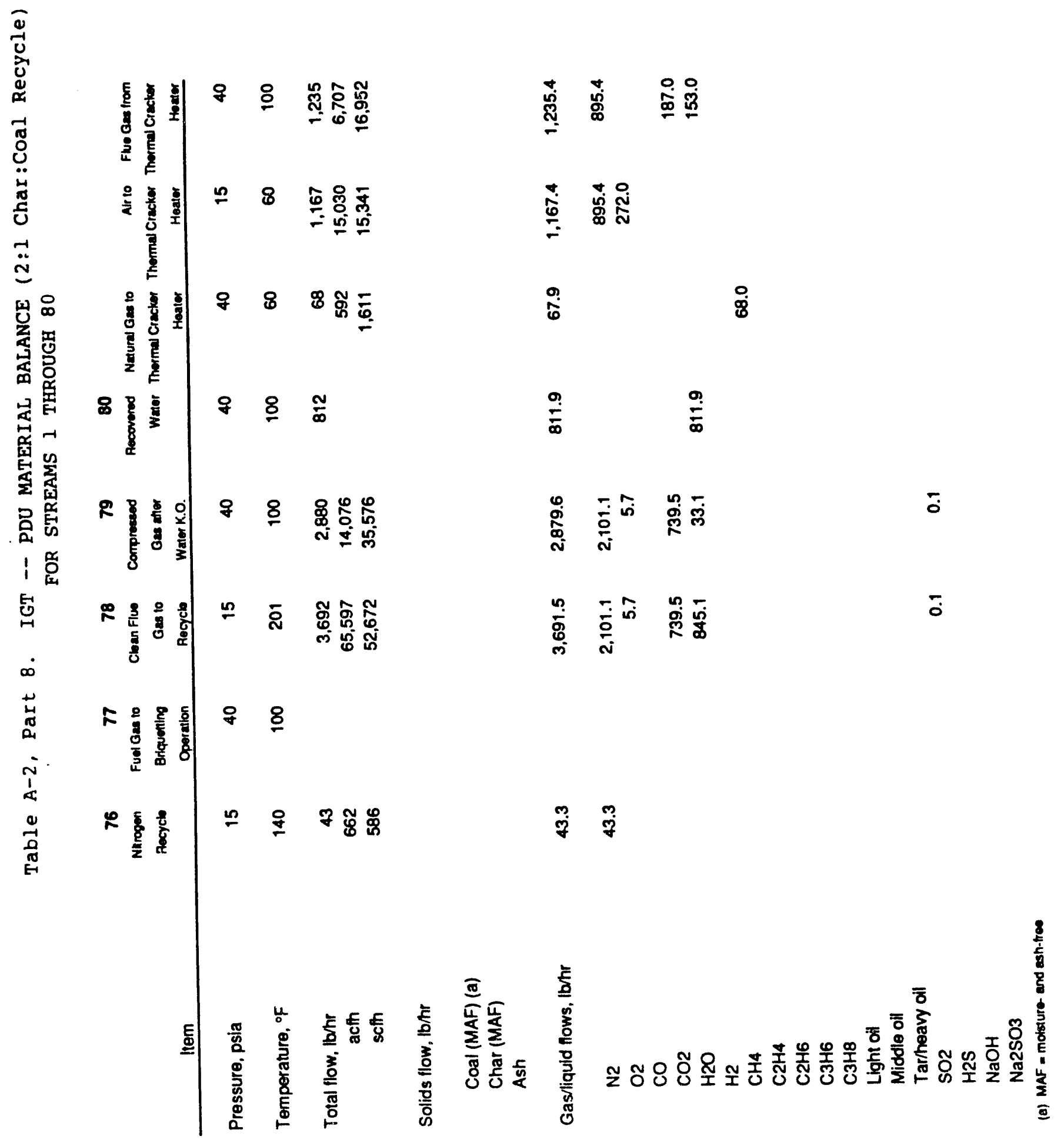


APPENDIX B. Equipment List

I I I - B- 1 


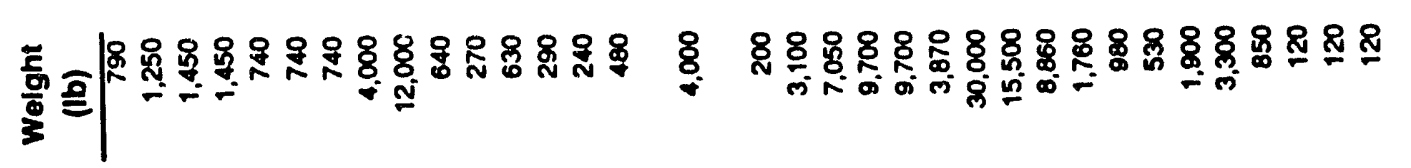

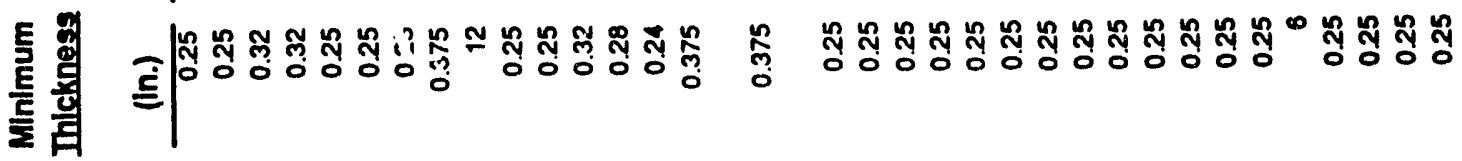

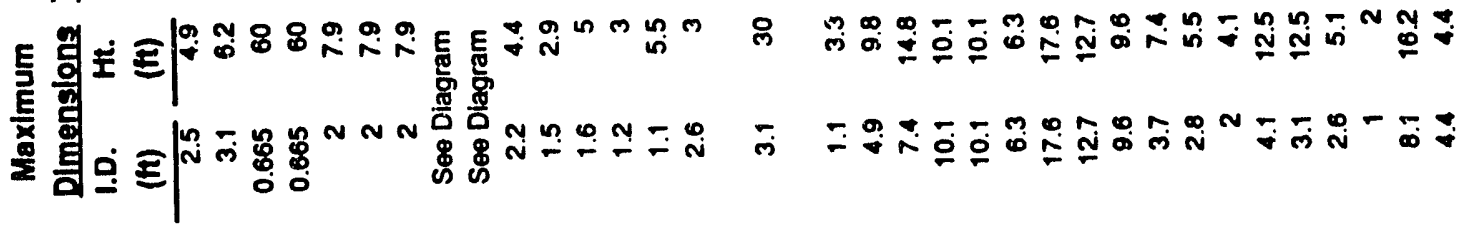

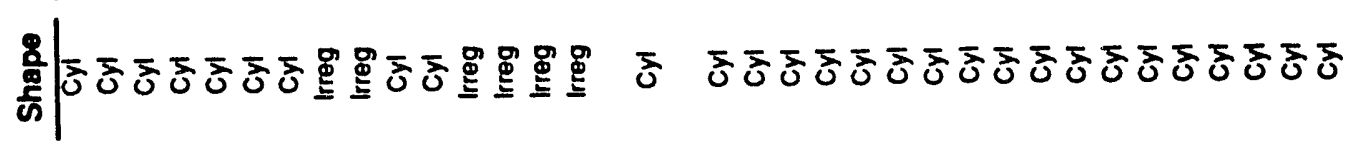

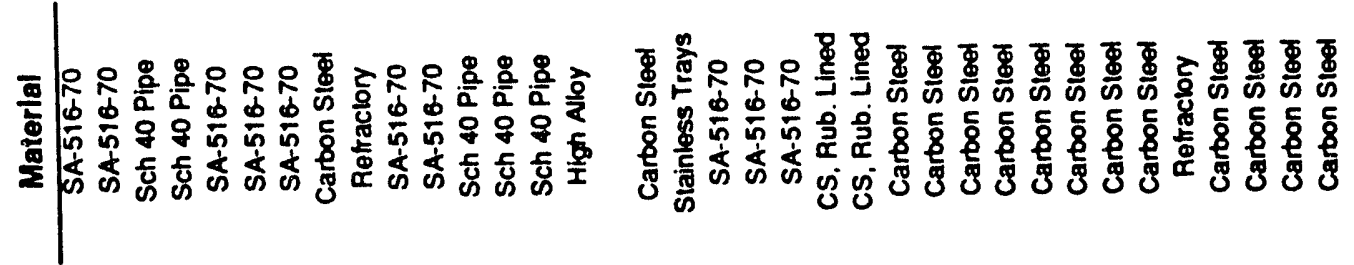

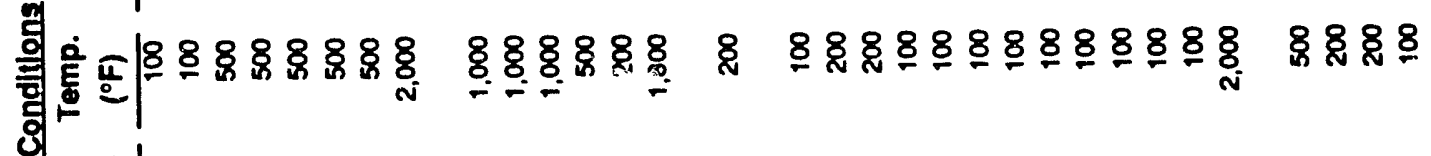

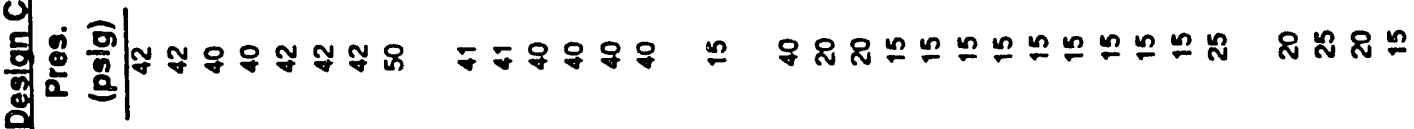

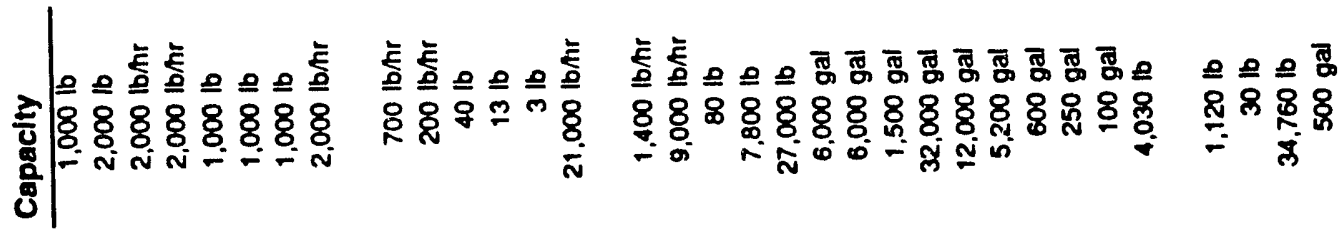

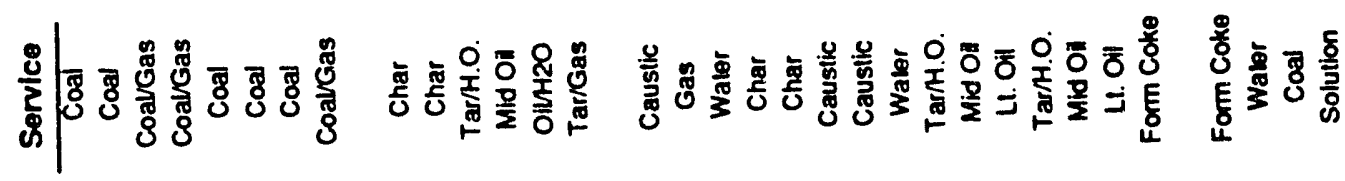

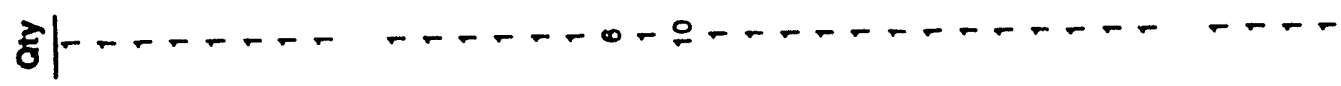

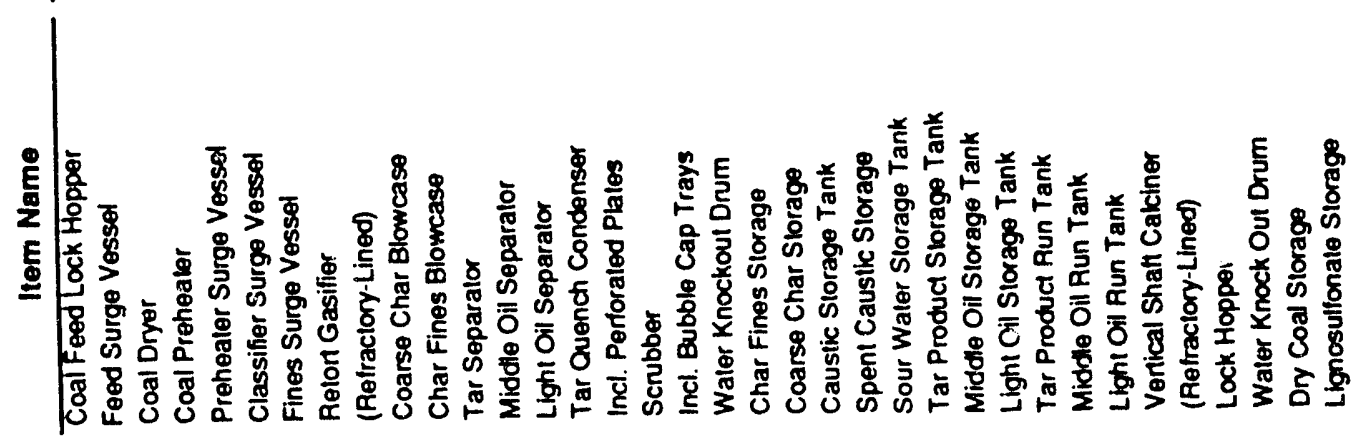

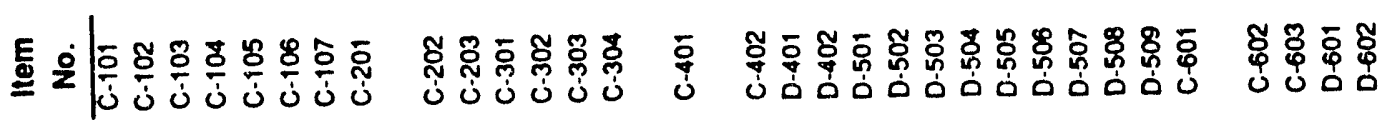




$$
\begin{aligned}
& \text { 혛 }
\end{aligned}
$$

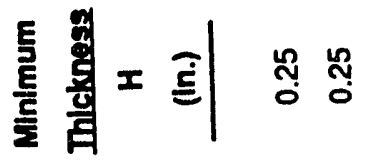

$$
\begin{aligned}
& \text { I } \cong \text { 웅 }
\end{aligned}
$$

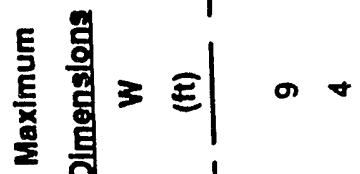

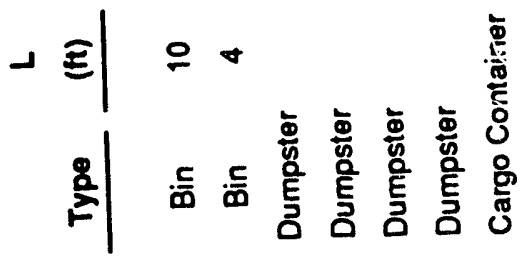

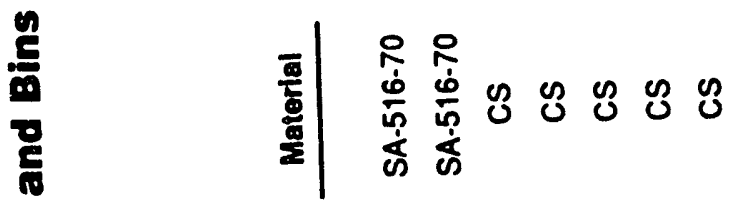

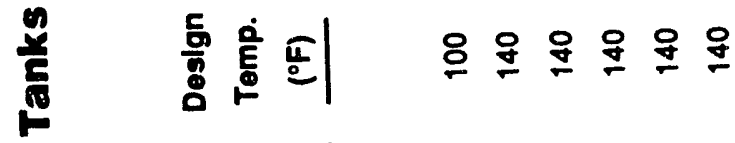

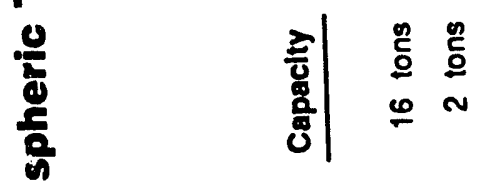

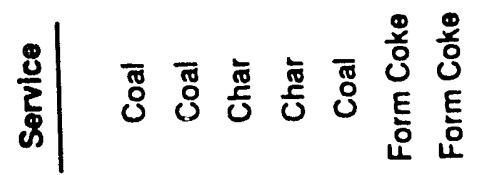

$$
\begin{aligned}
& \text { हे| - - - }
\end{aligned}
$$

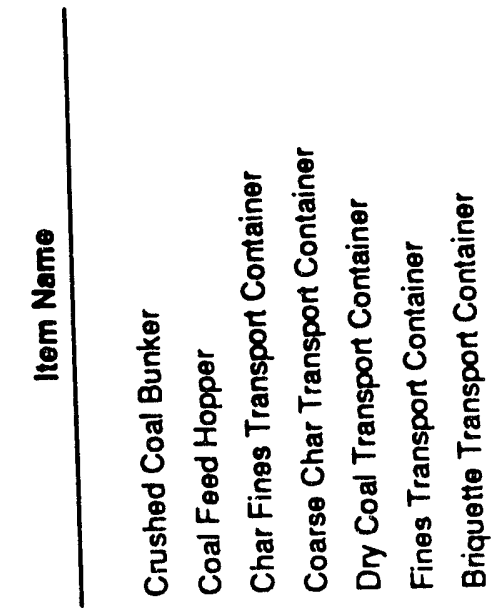

$$
\begin{aligned}
& \text { E }
\end{aligned}
$$




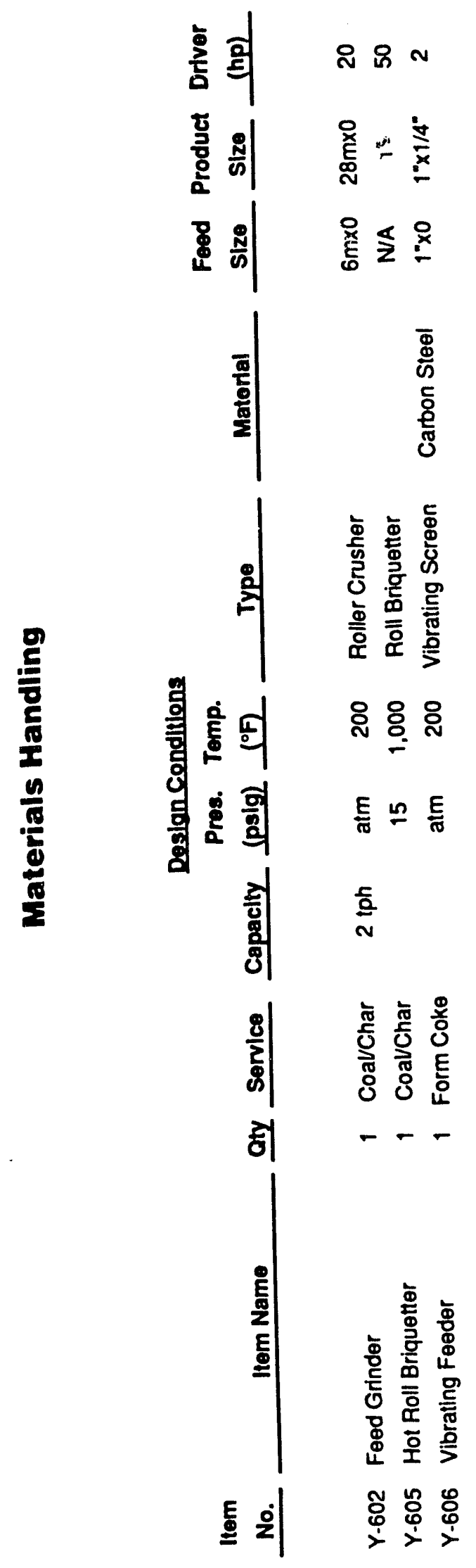




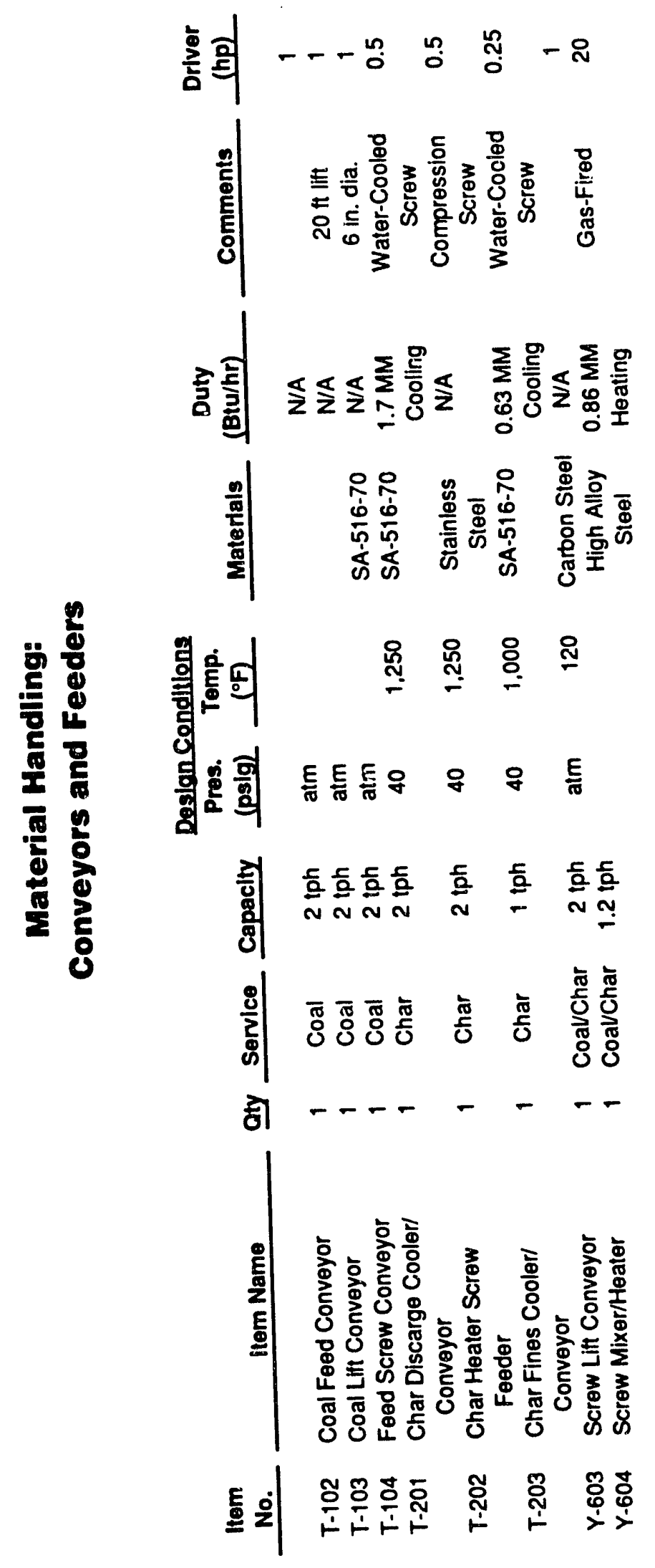




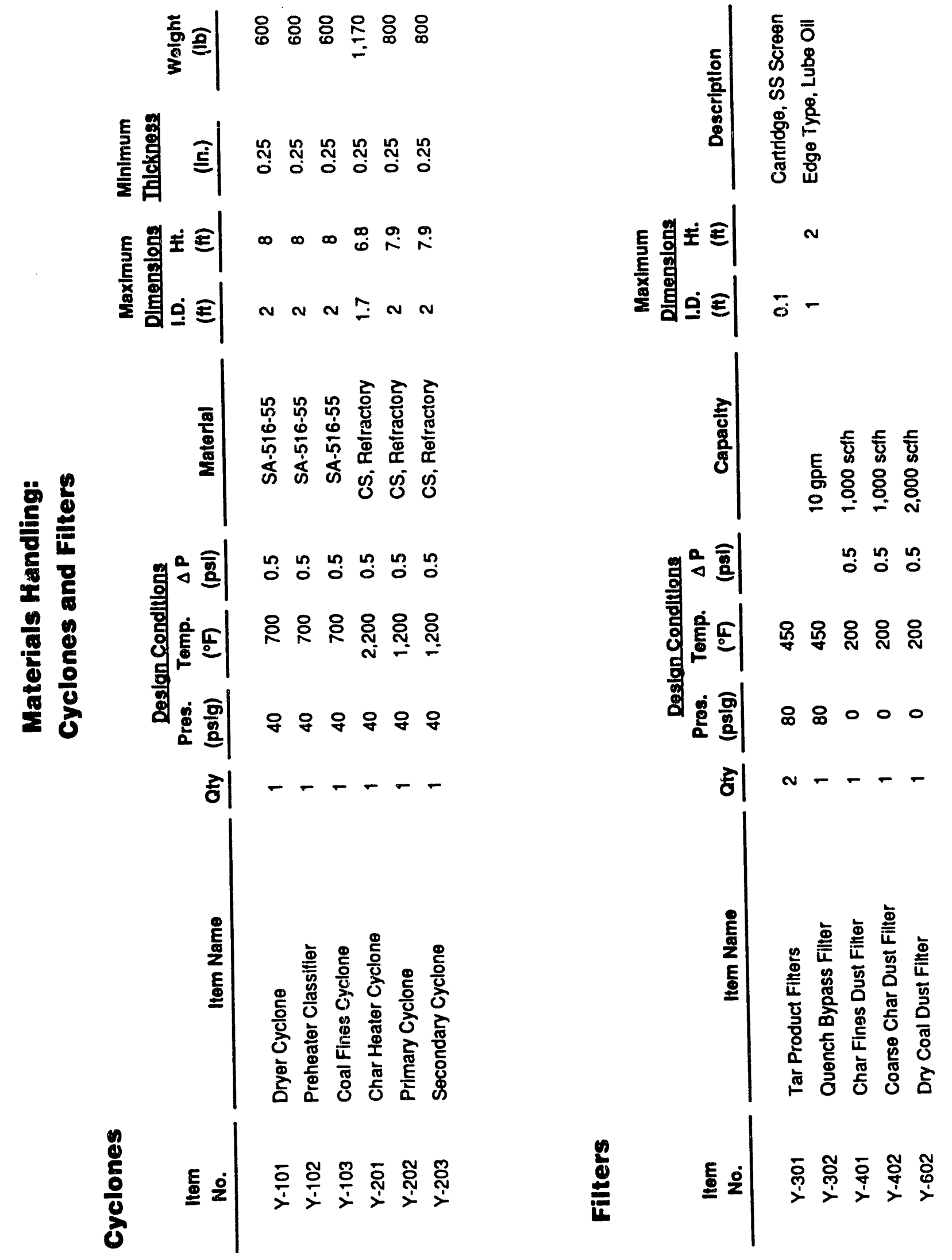


㖕或 总总总

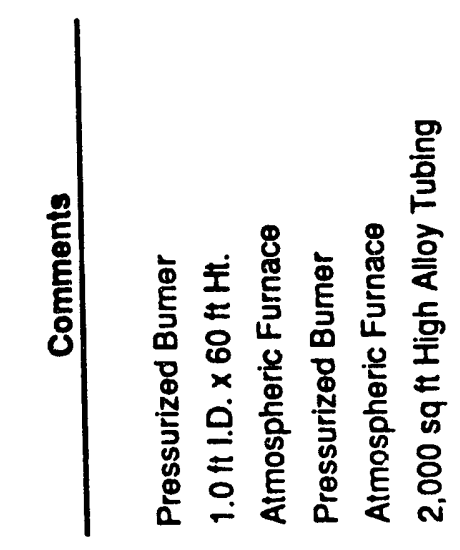

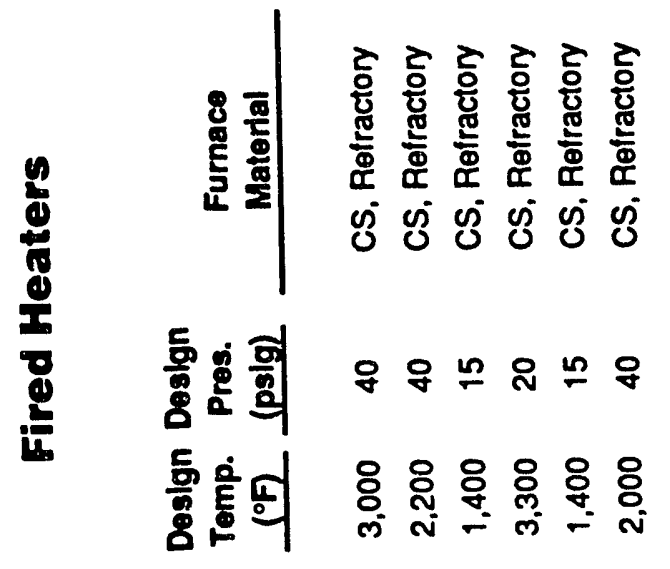

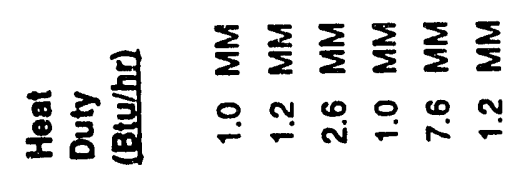

हो ……

||l|m| 


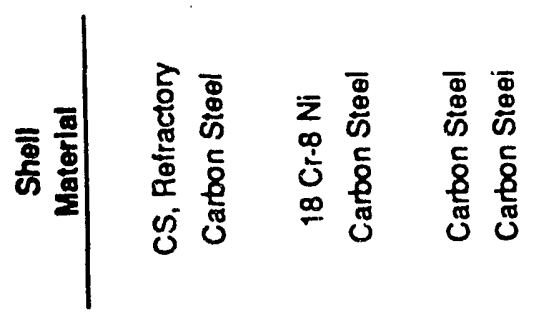

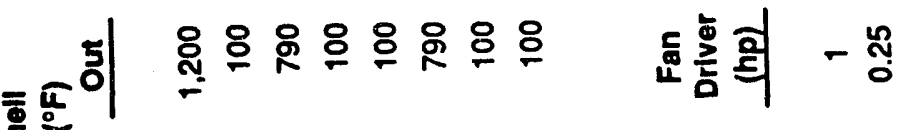

的容

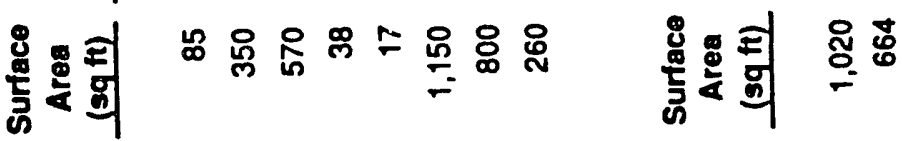

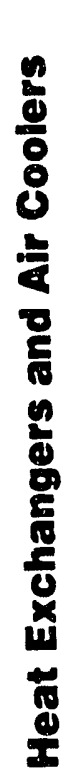

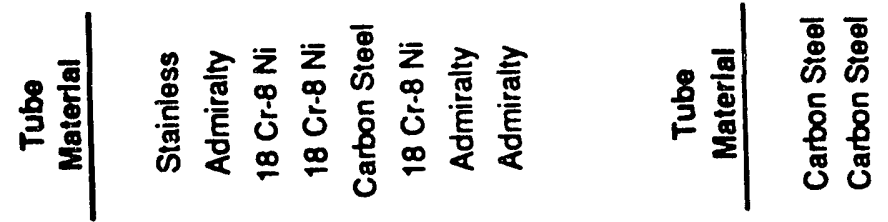

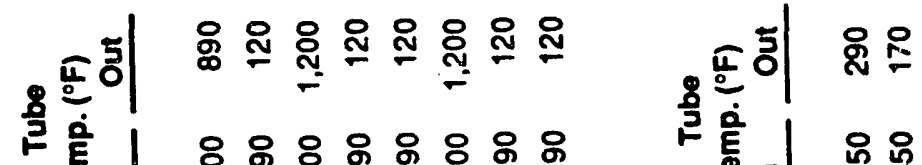

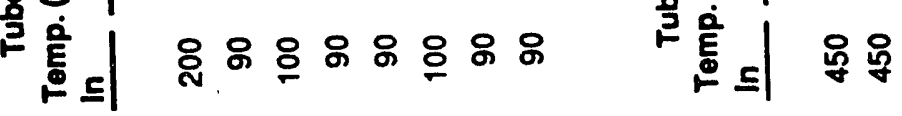

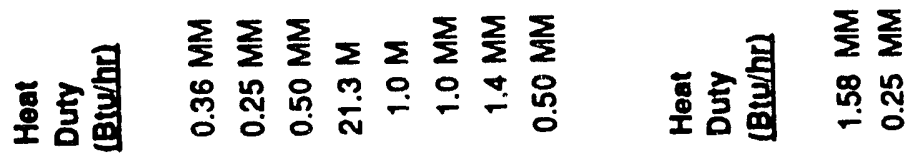

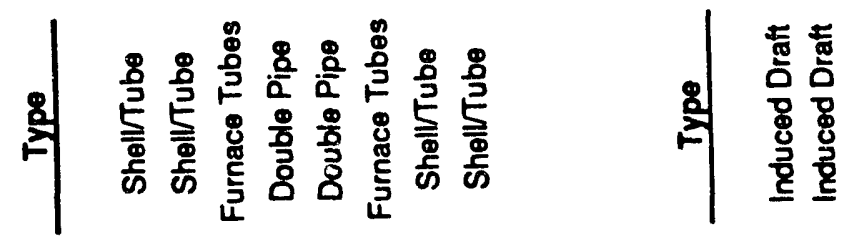

हो -

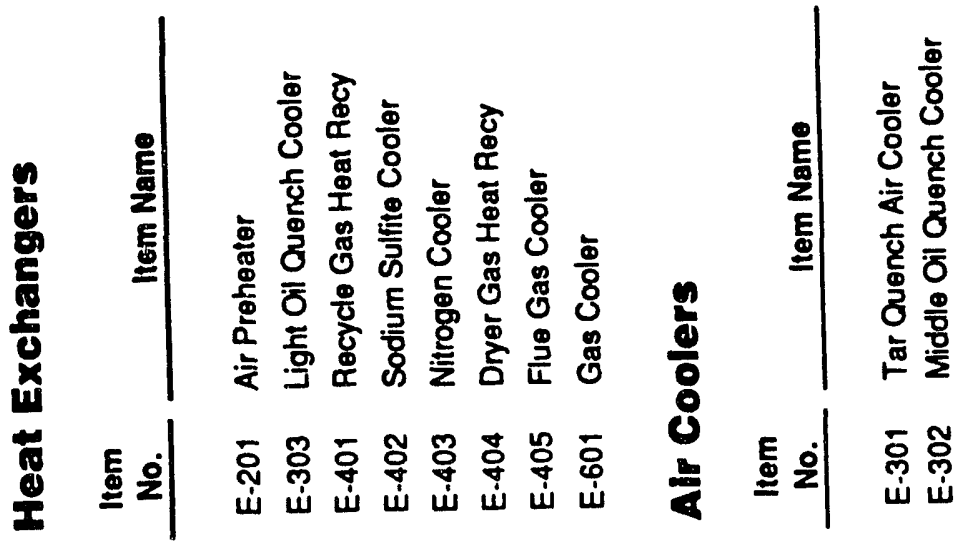


高高
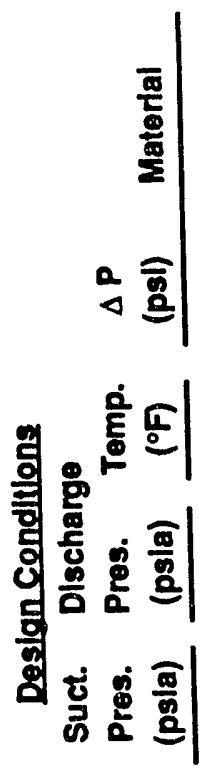

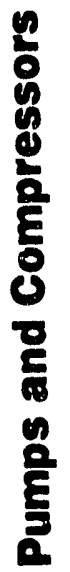
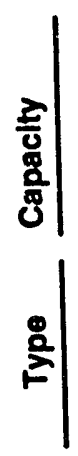

紊

히

E

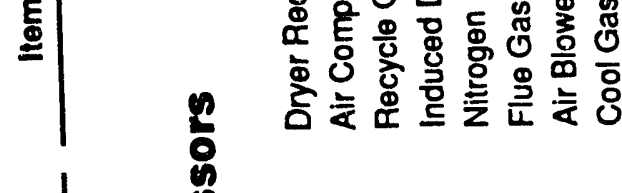

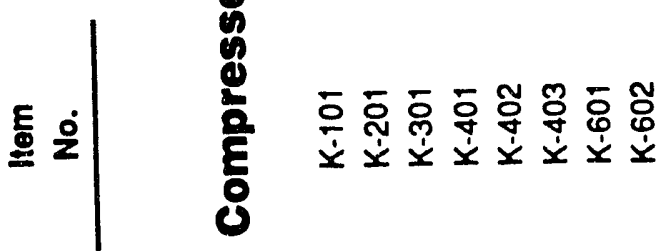

I I I $-B-10$

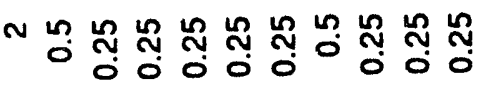

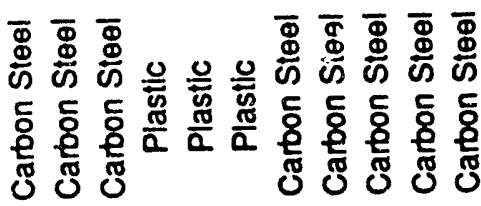

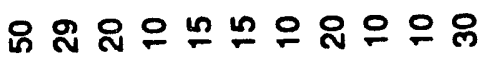

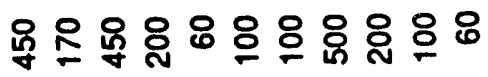

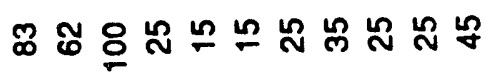

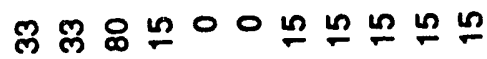

틍 틍흐ㅇㅡㅡㅇ 틍 틍 틍 틍 틍 틍 틍

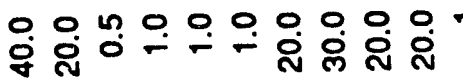

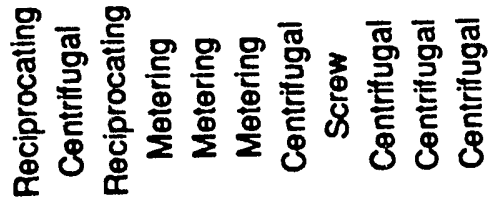

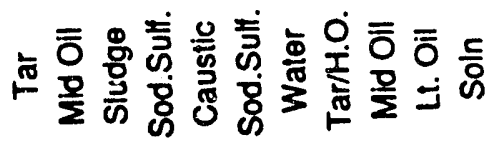

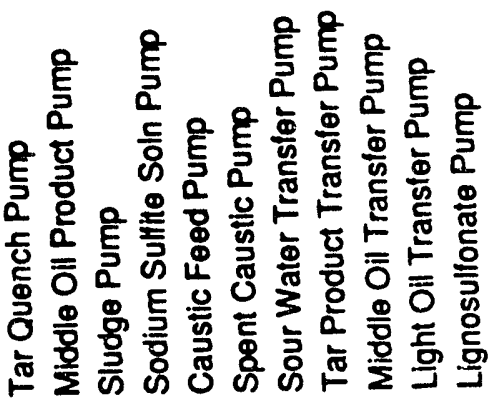

हू

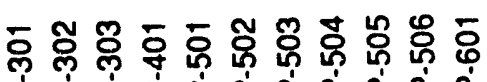
a d a da a a a a 
APPENDIX C. Piping and Instrumentation Drawings and Electrical One-Line Drawing 
PIPING AND INSTRUMENTATION DRAWINGS AND ELECTRICAL ONE-LINE DRAWING

Dwg. No.

\begin{tabular}{|c|}
\hline$A-00$ \\
\hline$A-01$ \\
\hline$A-02$ \\
\hline$A-03$ \\
\hline$A-04$ \\
\hline$A-05$ \\
\hline$A-06$ \\
\hline$A-07$ \\
\hline$A-08$ \\
\hline$A-09$ \\
\hline$A-10$ \\
\hline$A-11$ \\
\hline$A-12$ \\
\hline$A-13$ \\
\hline$A-14$ \\
\hline$A-15$ \\
\hline$A-16$ \\
\hline$E-01$ \\
\hline
\end{tabular}

Name

Symbols and Legends

Coal Handling

Coal Drying

Gasifier Heat Supply

Gasifier

Hot Gas Fines Removal

Heavy Oil/Tar Recovery

Middle and Light oil Recovery

Incinerator

Emission Control

Chemical Solution Storage and Handling

Coal-Oil Products storage and Handling

Char and Coal storage and Handling

Briquette Forming

Briquette Calcining

Calciner Air and Heat Supply

Process Utilities

Preliminary Single-Line Diagram
Revision

A

B

B

B

B

B

B

B

B

B

B

B

B

B

B

B

A 


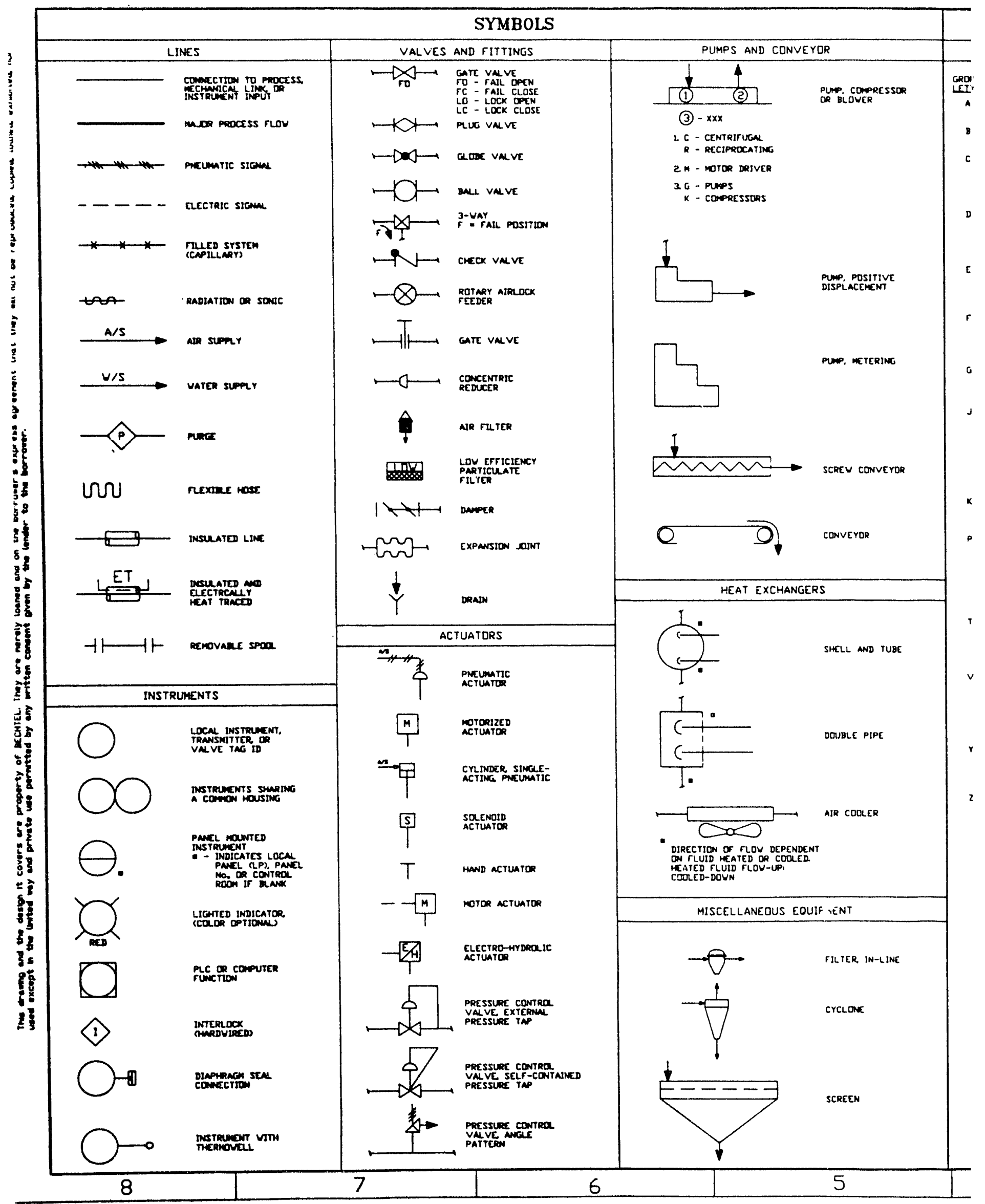




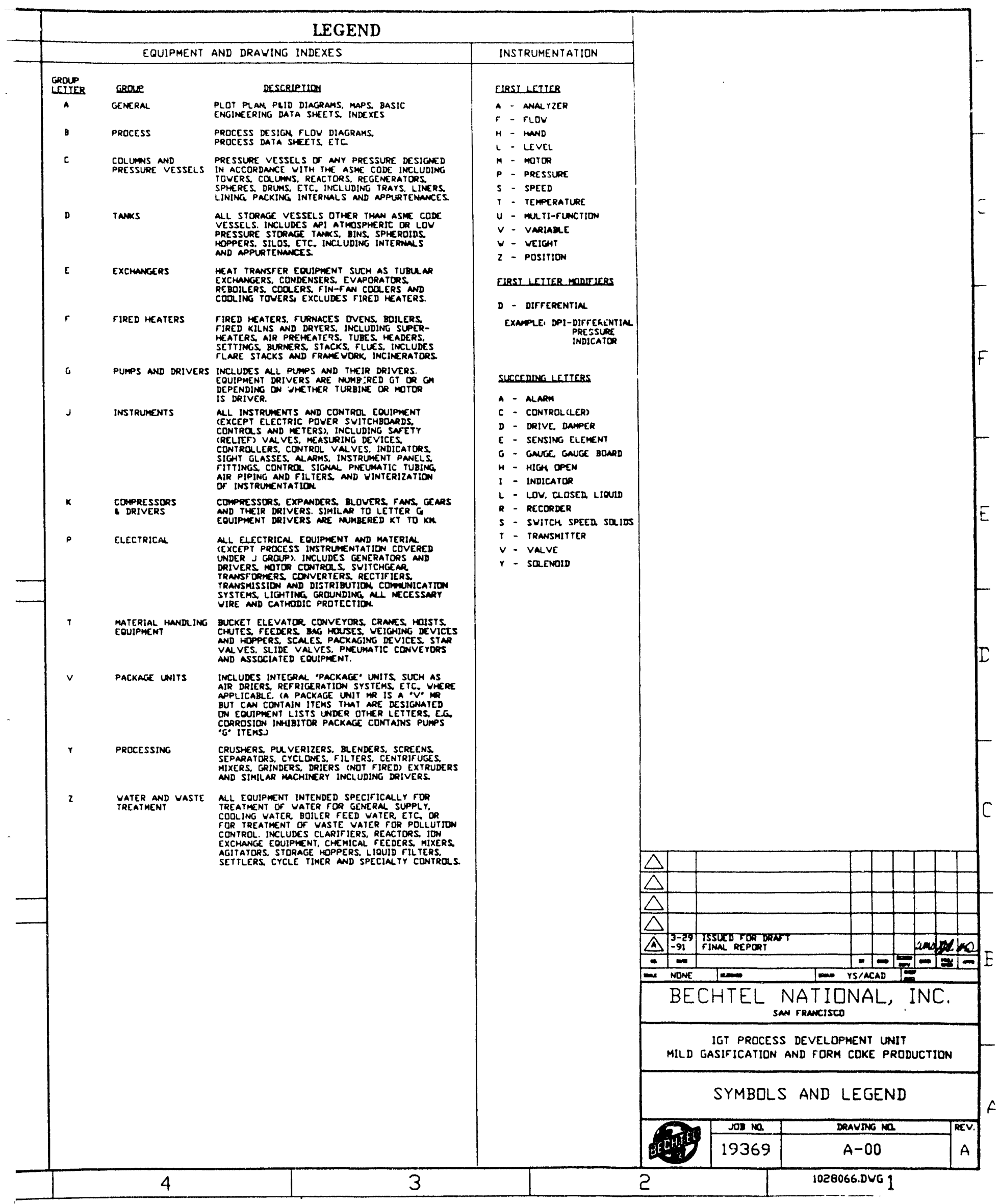




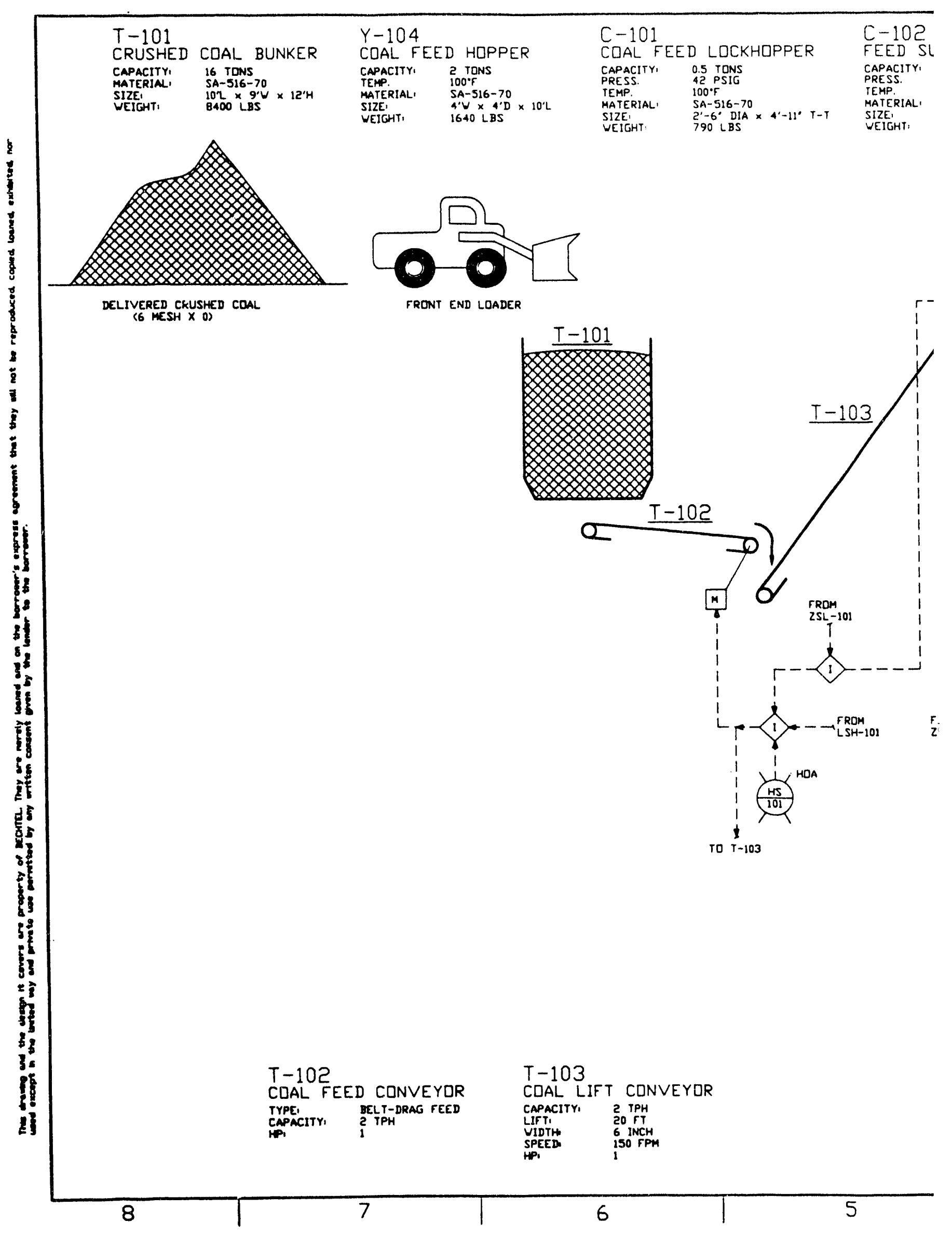


$C-102$

FEED SURGE VESSEL

CAPACITY, 1 TON

$\begin{array}{ll}\text { PRESS. } & 42 \text { PSIG } \\ \text { TEMP. } & 100^{\circ} \mathrm{F}\end{array}$

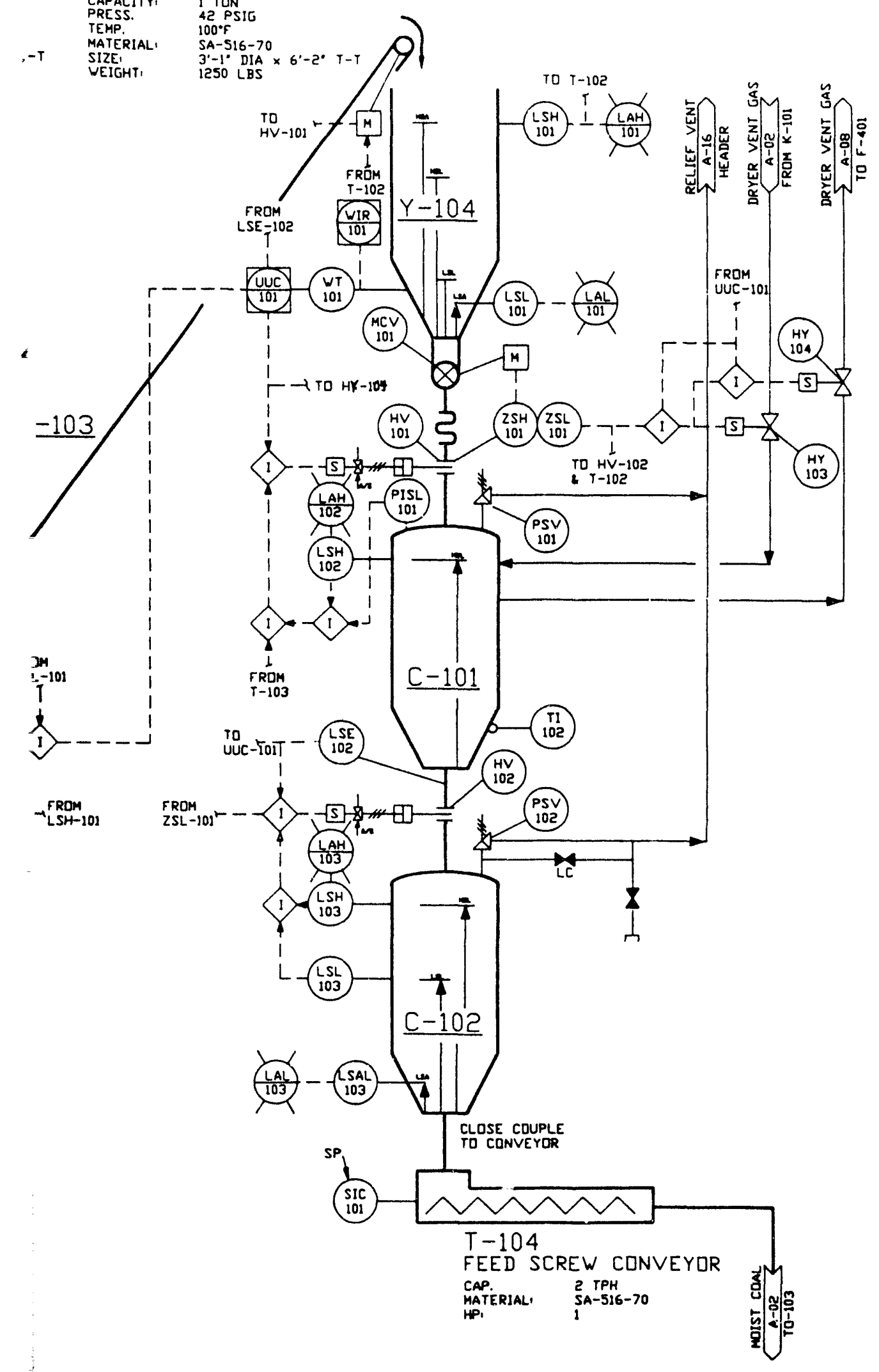

Nares:

1. ALL MAJOR EQUIPMENT TO HAVE LOCAL JOG / EMERGENCY STOP.

2. ALL. VENT AND DRAIN CONNECTIONS OPEN O ATMOSPHERE SHALL BE CAPPED DR

Tm ?

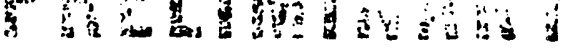

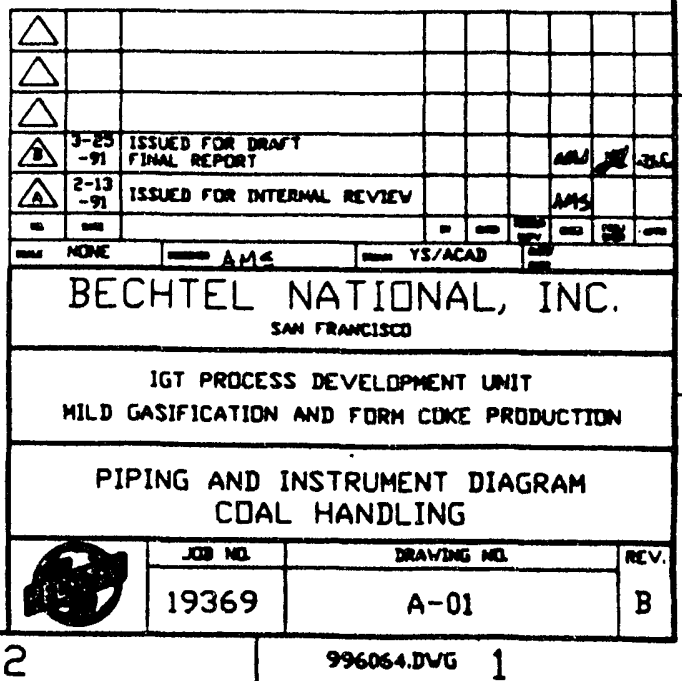




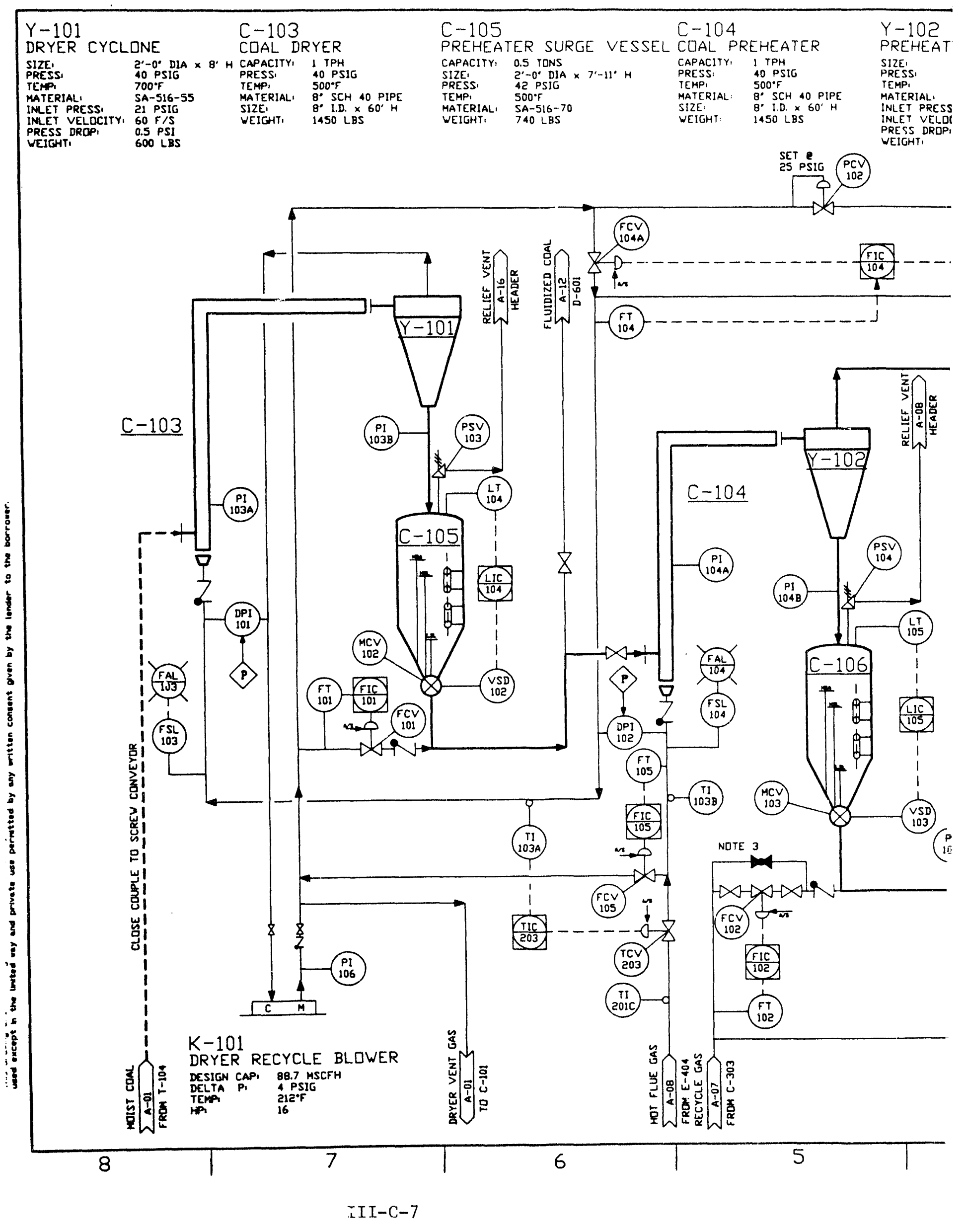




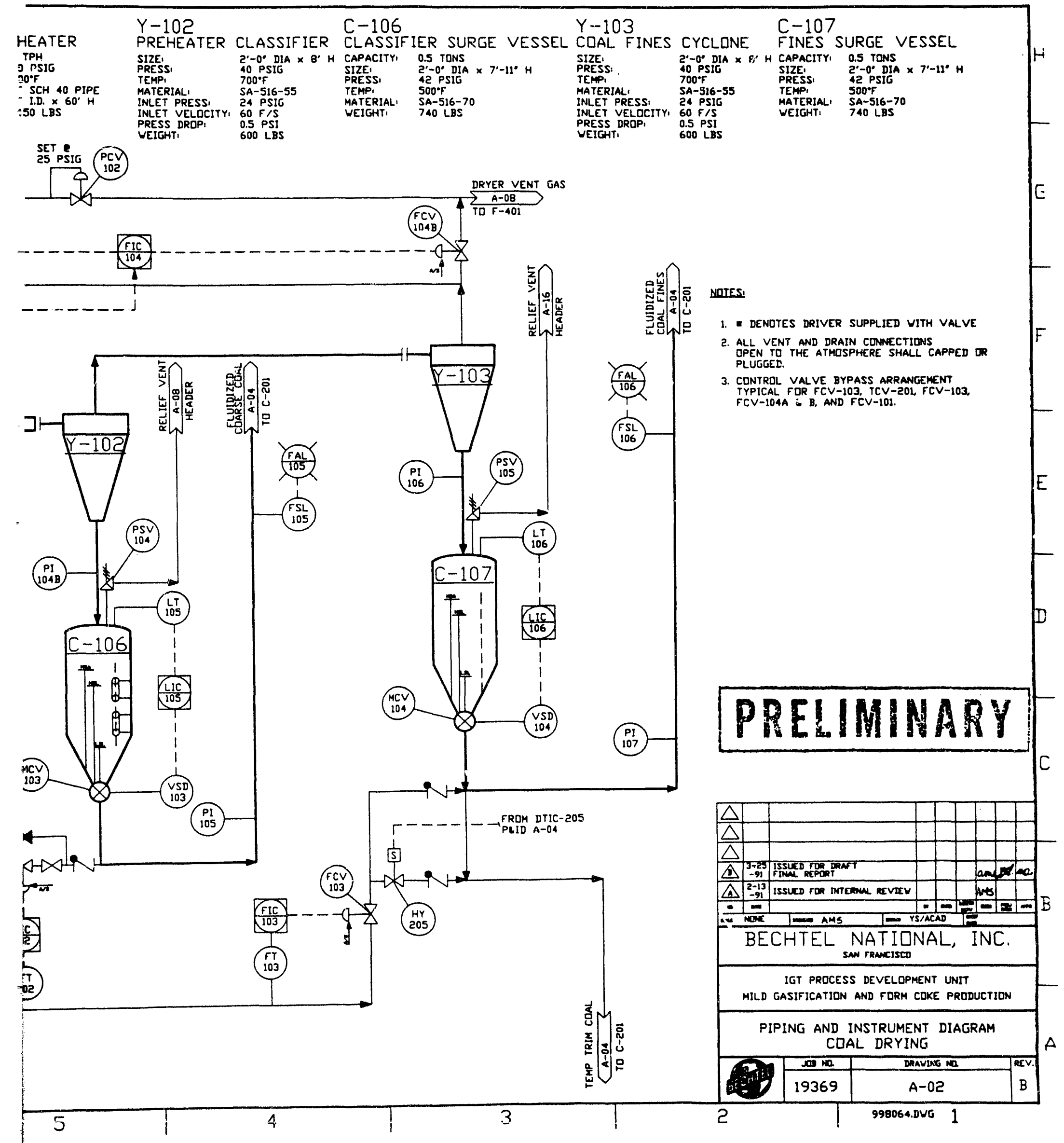


$Y-201$

CHAR HEATER CYCLINE PRESSI 40 PSIG

TEMPI

HATERIALI C.S.

LINING
SIZE 1

VEIGHT, 700 LBS $W /$ REF.

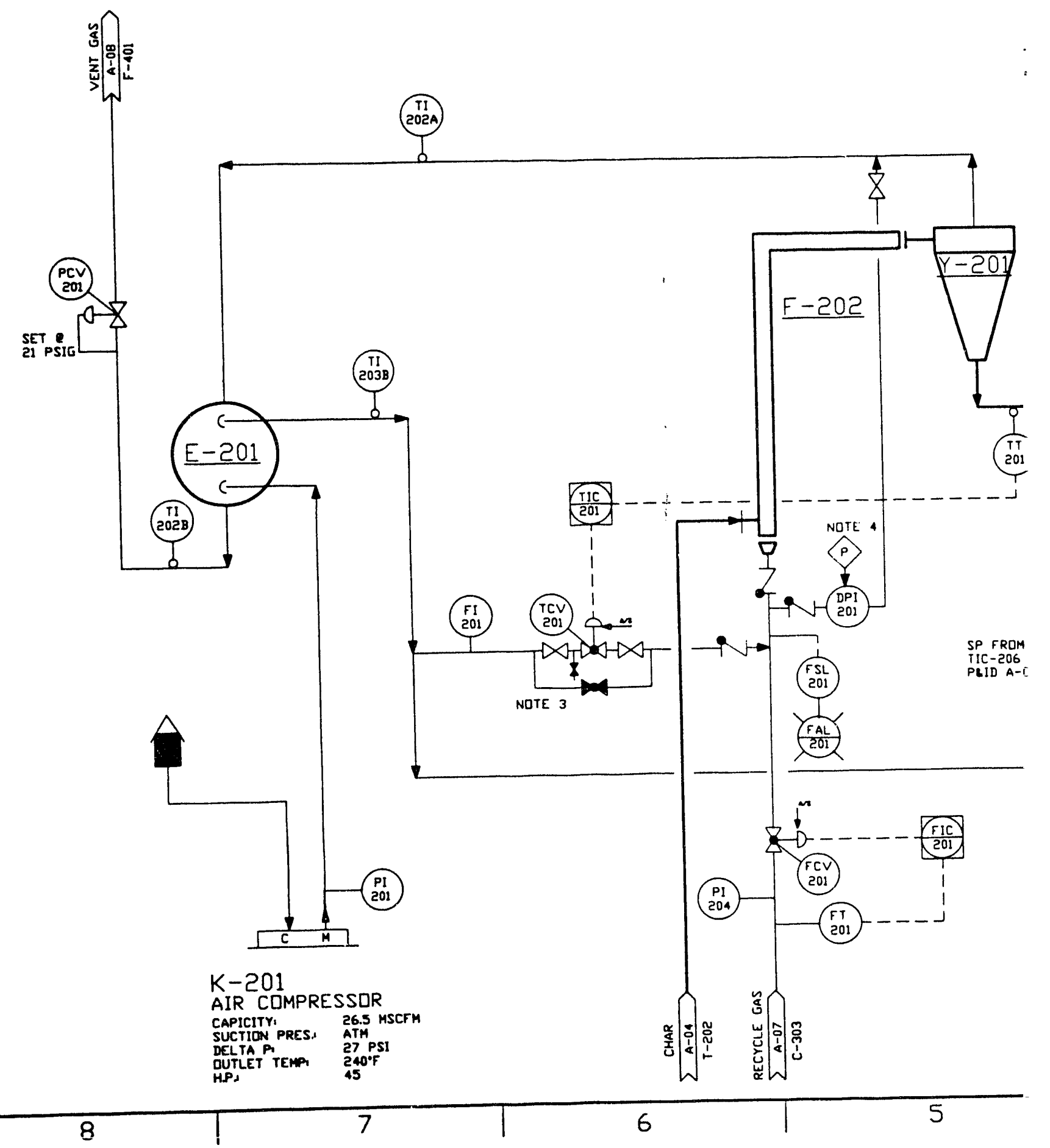


$F-201$

GASIFIER BODSTER HEATER

HEAT DUTY, 1 MM BTU/HR

TEMPI $\quad 40$ PSIG

MATERIAL: C.S. REF. LINED

ABLE REF.

$\times 6^{\prime}-10^{\circ}$

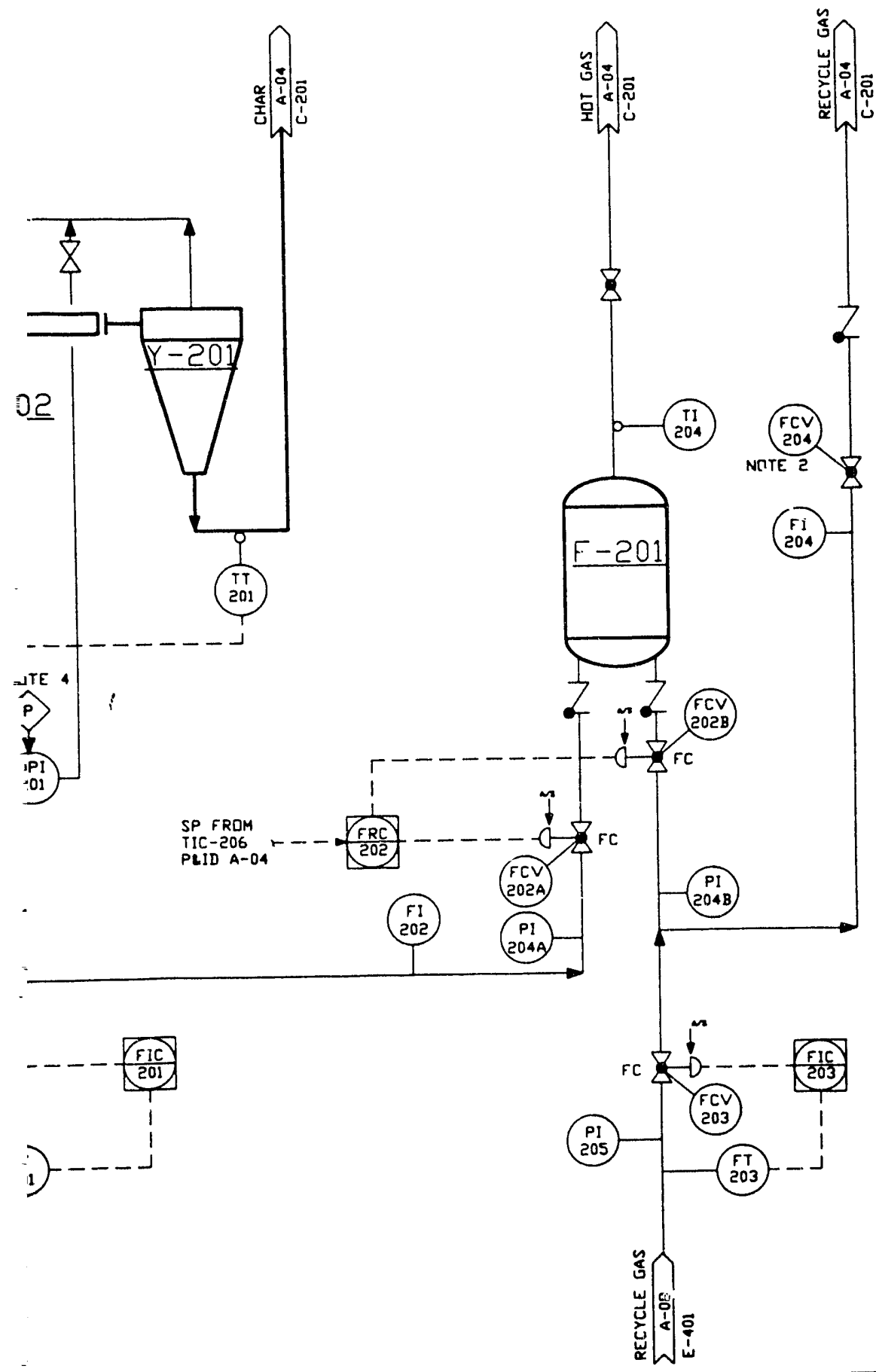

NDIES,

1. ALL VENT AND DRAIN CDNNECTIONS PLUGGED.

2. SET FLDW AT RECYCLE CHAR TD CDAL FEED RATI ALLOU FLOU TO FLDAT UITHIN LAMITS DURING OPERATION.

3. CONTROL VALVE BYPASS ARRANGEMENT TYPICAL FOR FCV-ZO2A FCV-202B, FCV-202 \& FCV-201.

4. PURGE GAS SYSTEM SHALL INCLUDE ALL NECESSARY VALVES AND FLOVMETERS.

\section{PRELIMINARY}

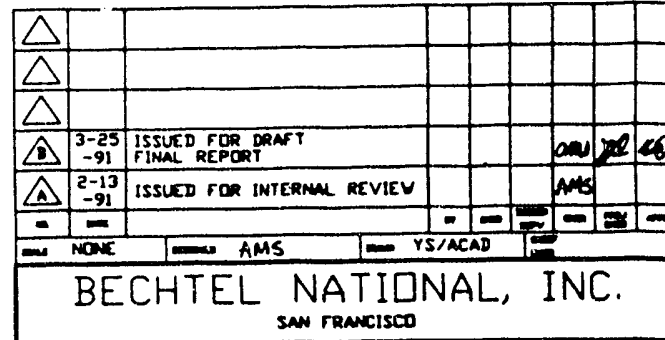

IGT PROCESS DEVELDPMENT UNIT MILD GASIFICATION AND FORM COKE PRODUCTION

PIPING AND INSTRUMENT DIAGRAM GASIFIER HEAT SUPPLY

\begin{tabular}{|c|c|}
\hline J010 & DEV \\
\hline 19369 & A-03 \\
\hline
\end{tabular}




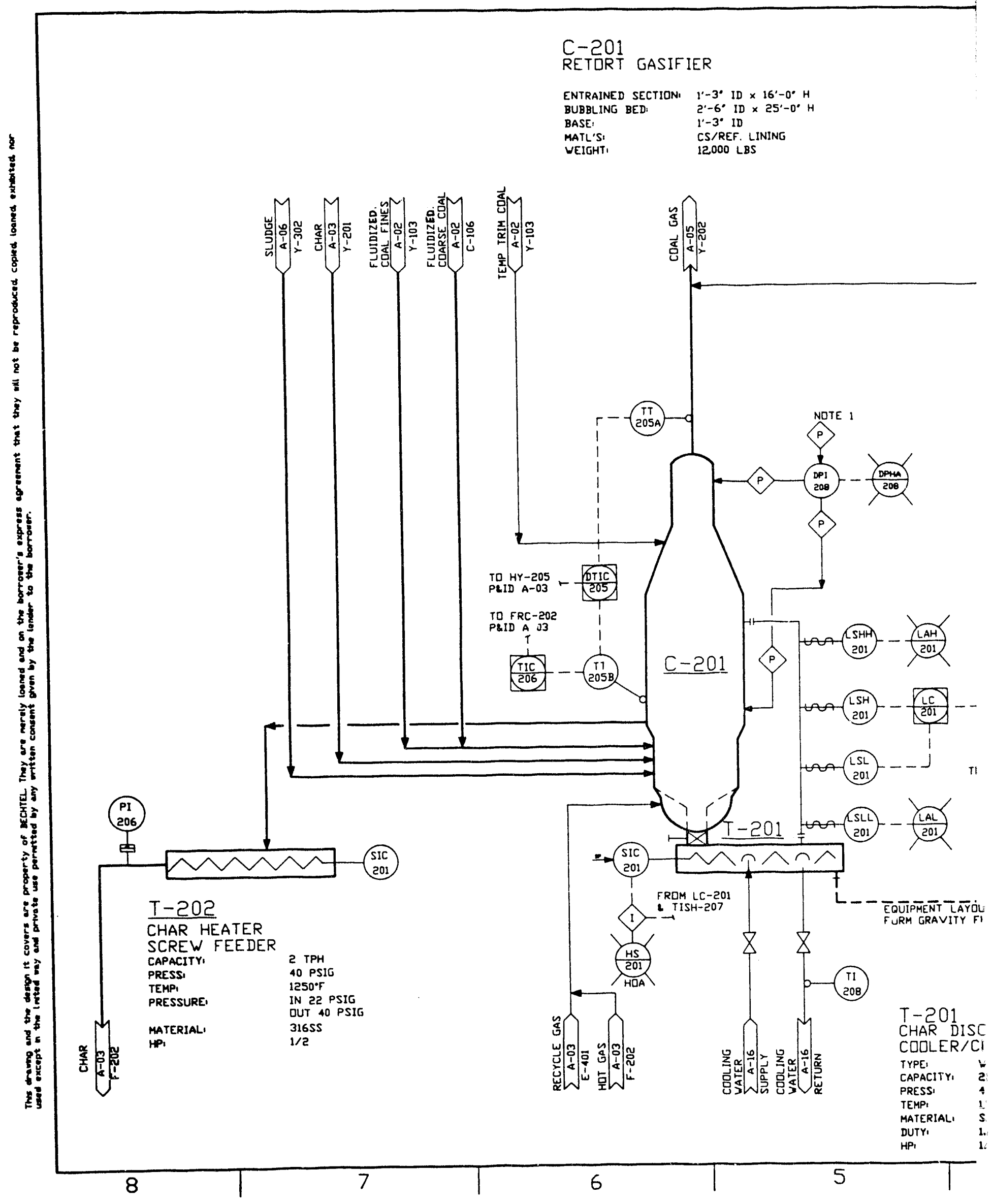


$C-202$

CDARSE CHAR BLDWCASE

$16^{\circ}-0^{\circ} \mathrm{H}$
$25^{\circ}-0^{\circ} \mathrm{H}$

INING

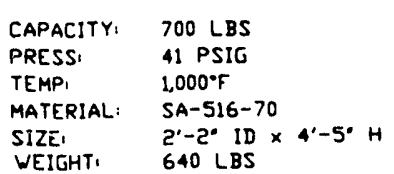

SIZE'I
WEIGHT

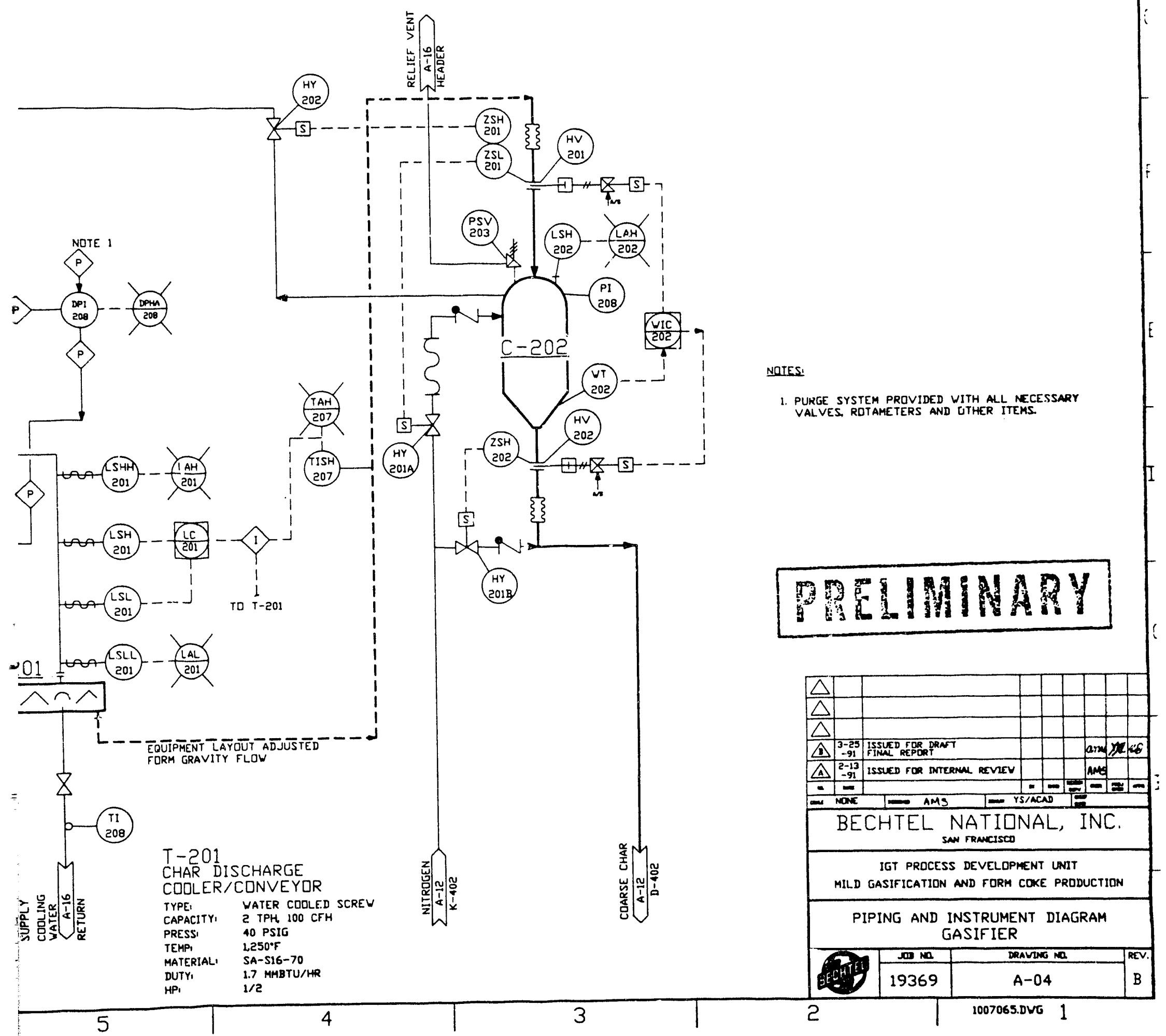




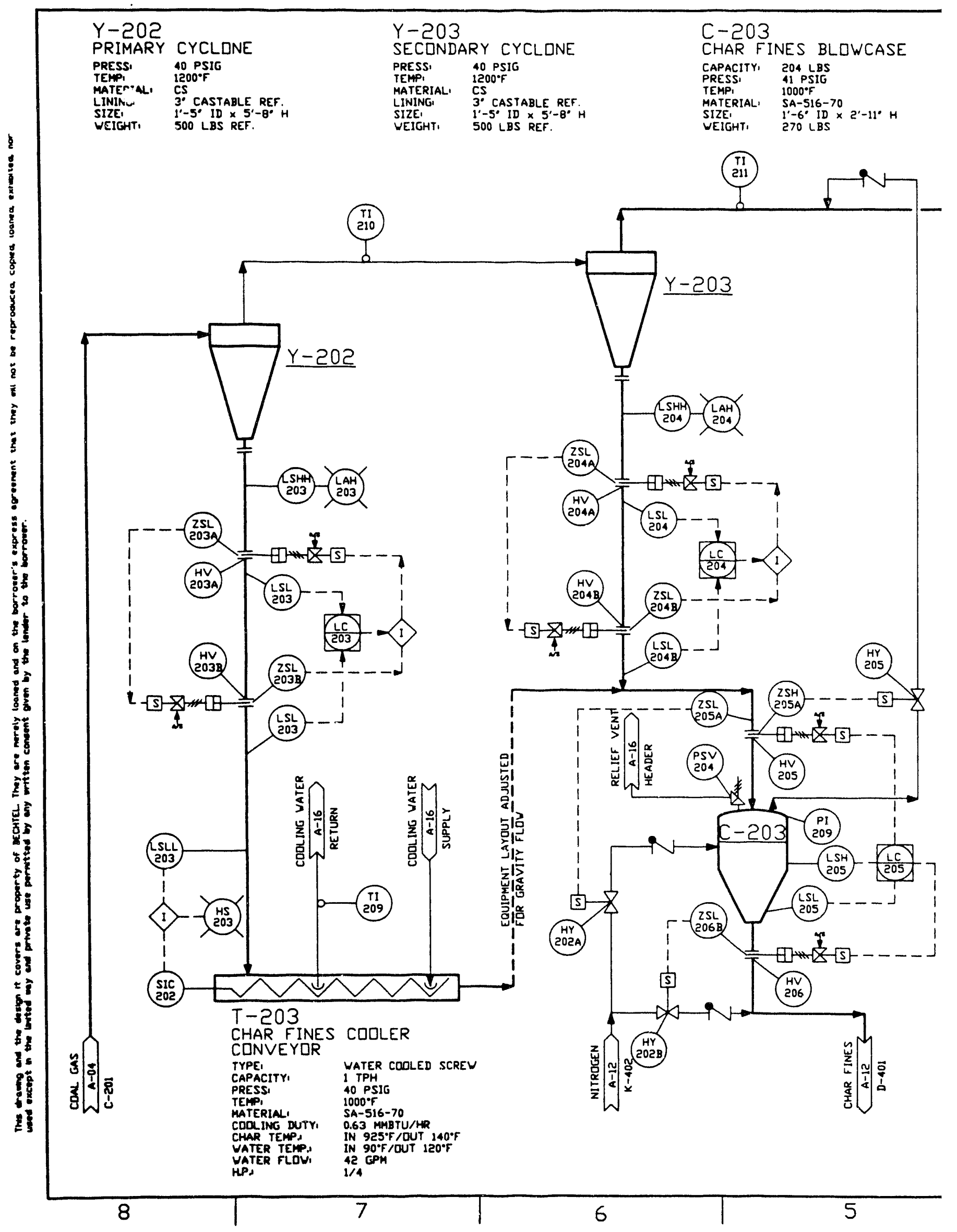




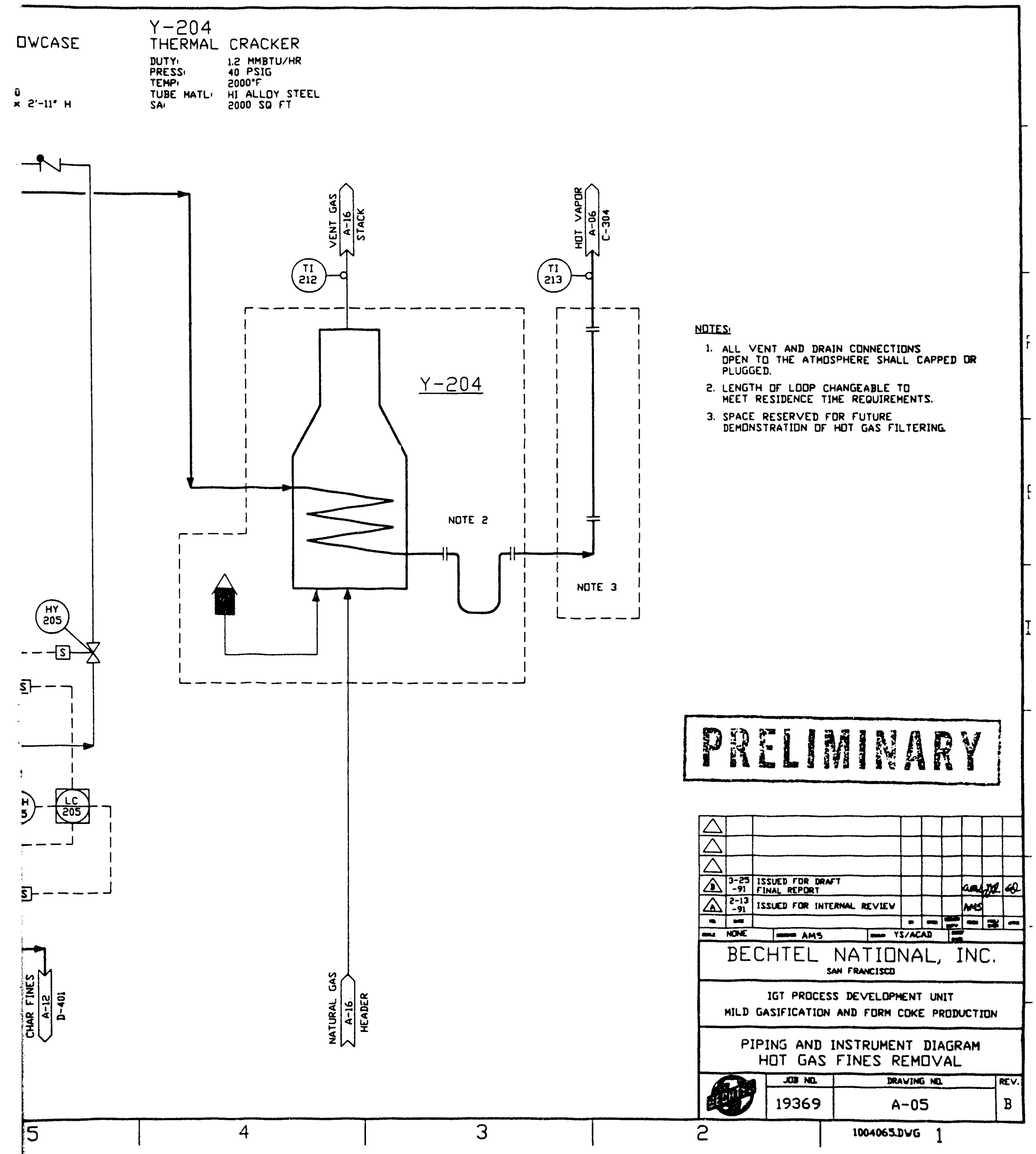




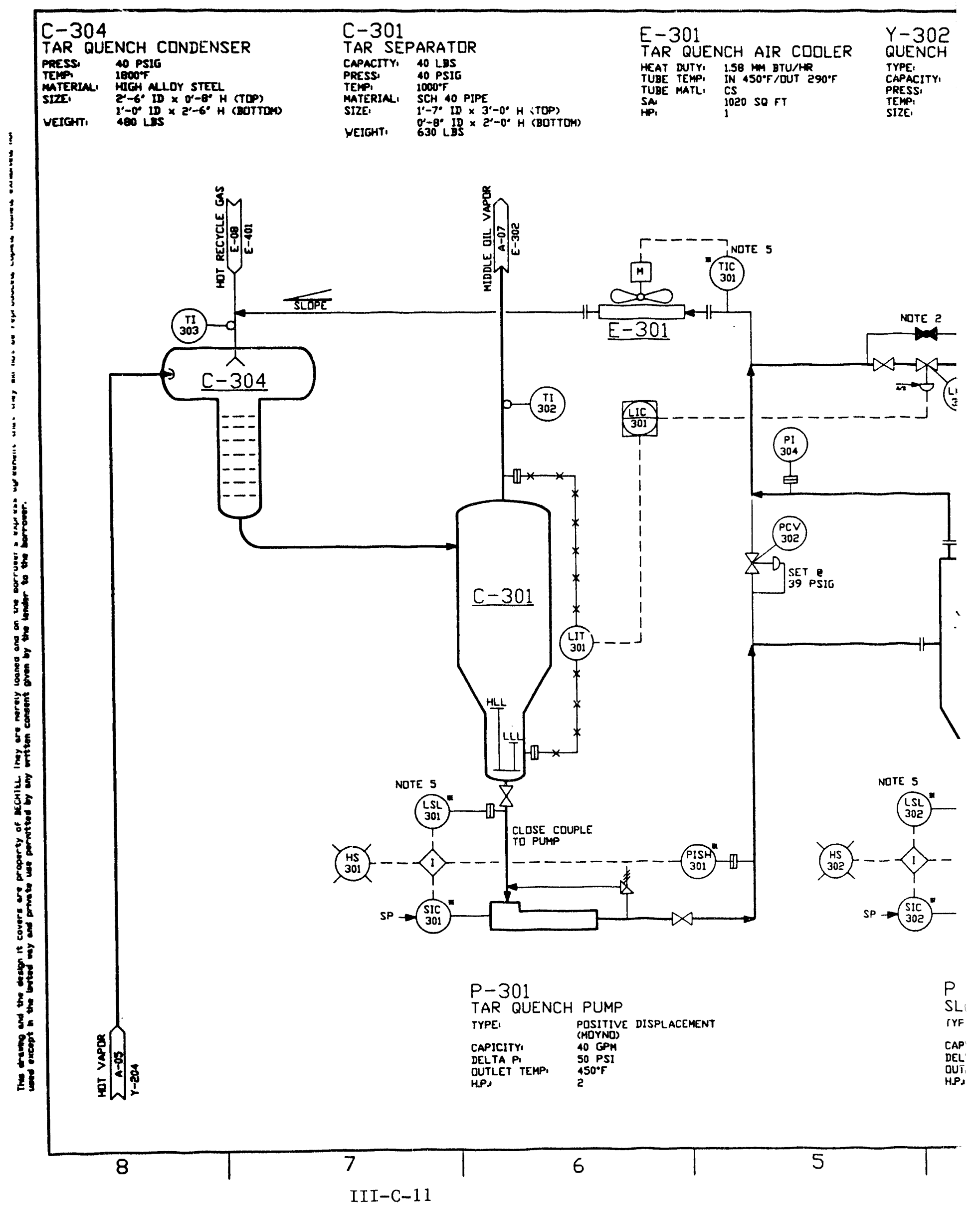




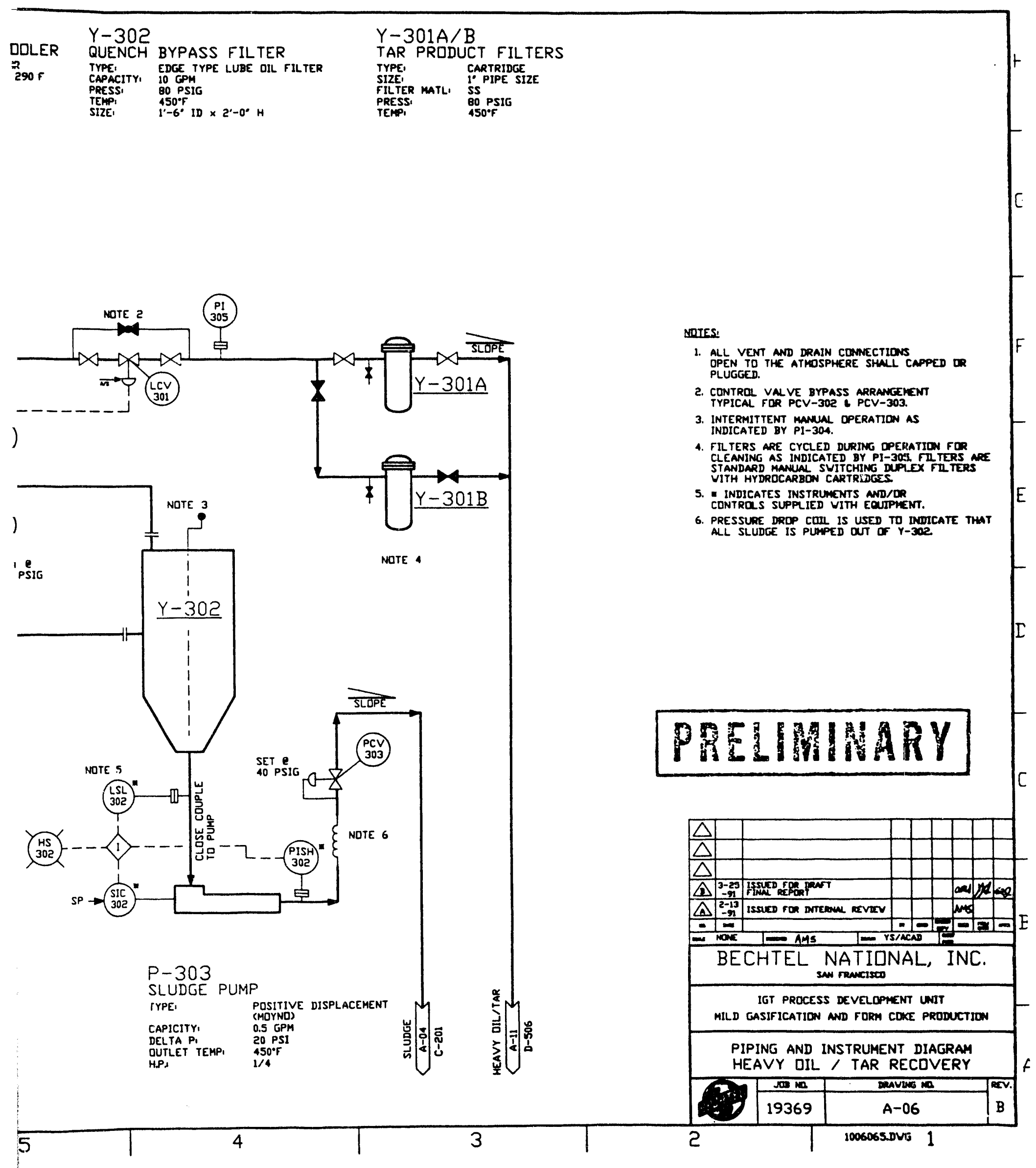




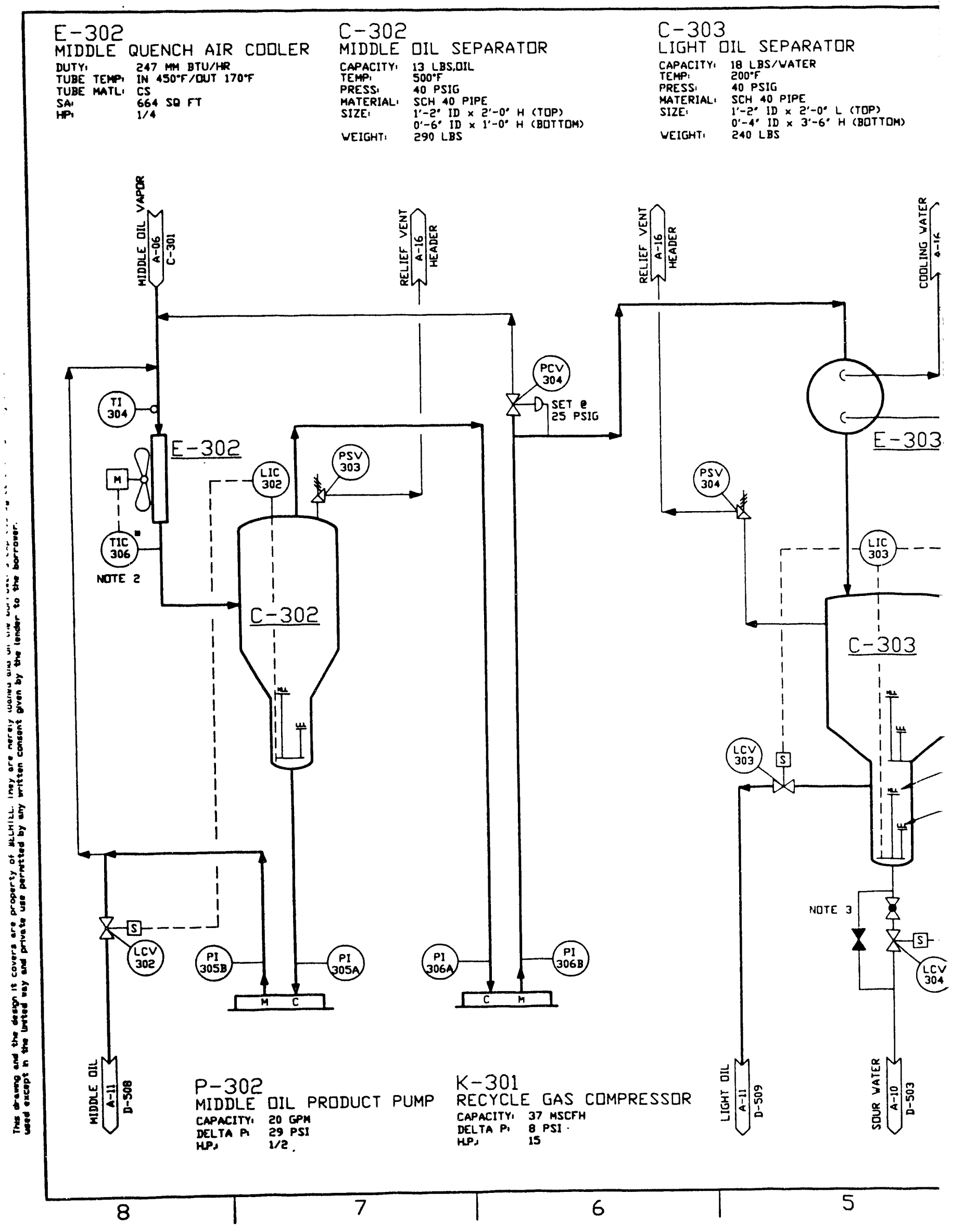




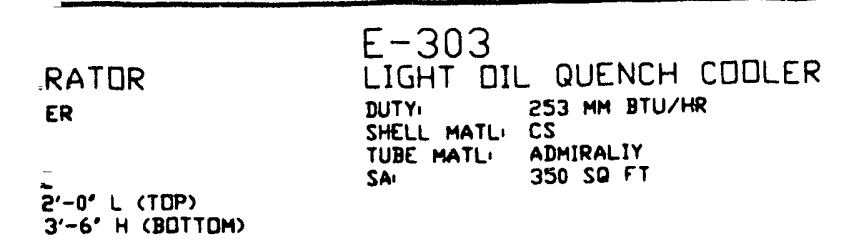

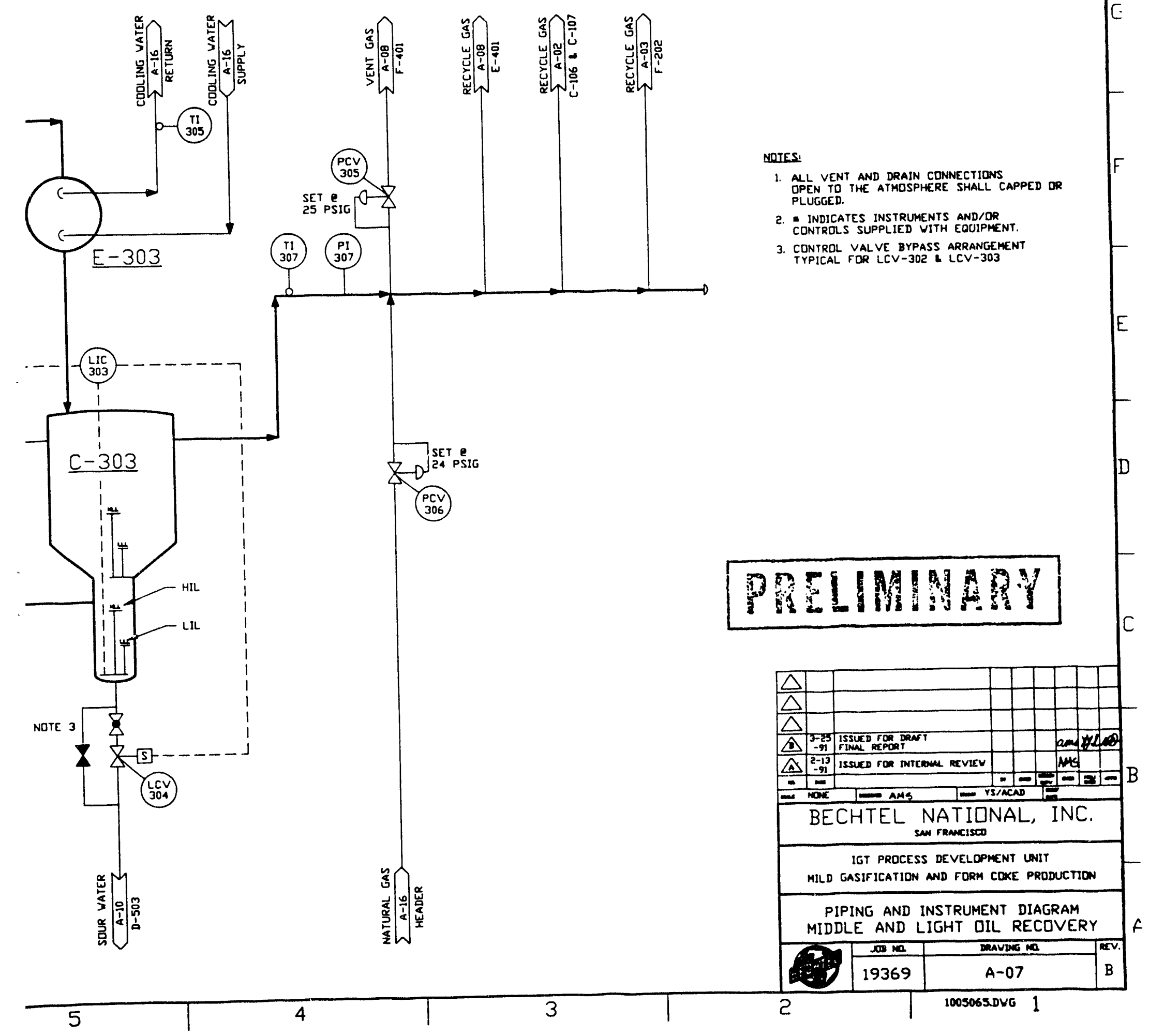




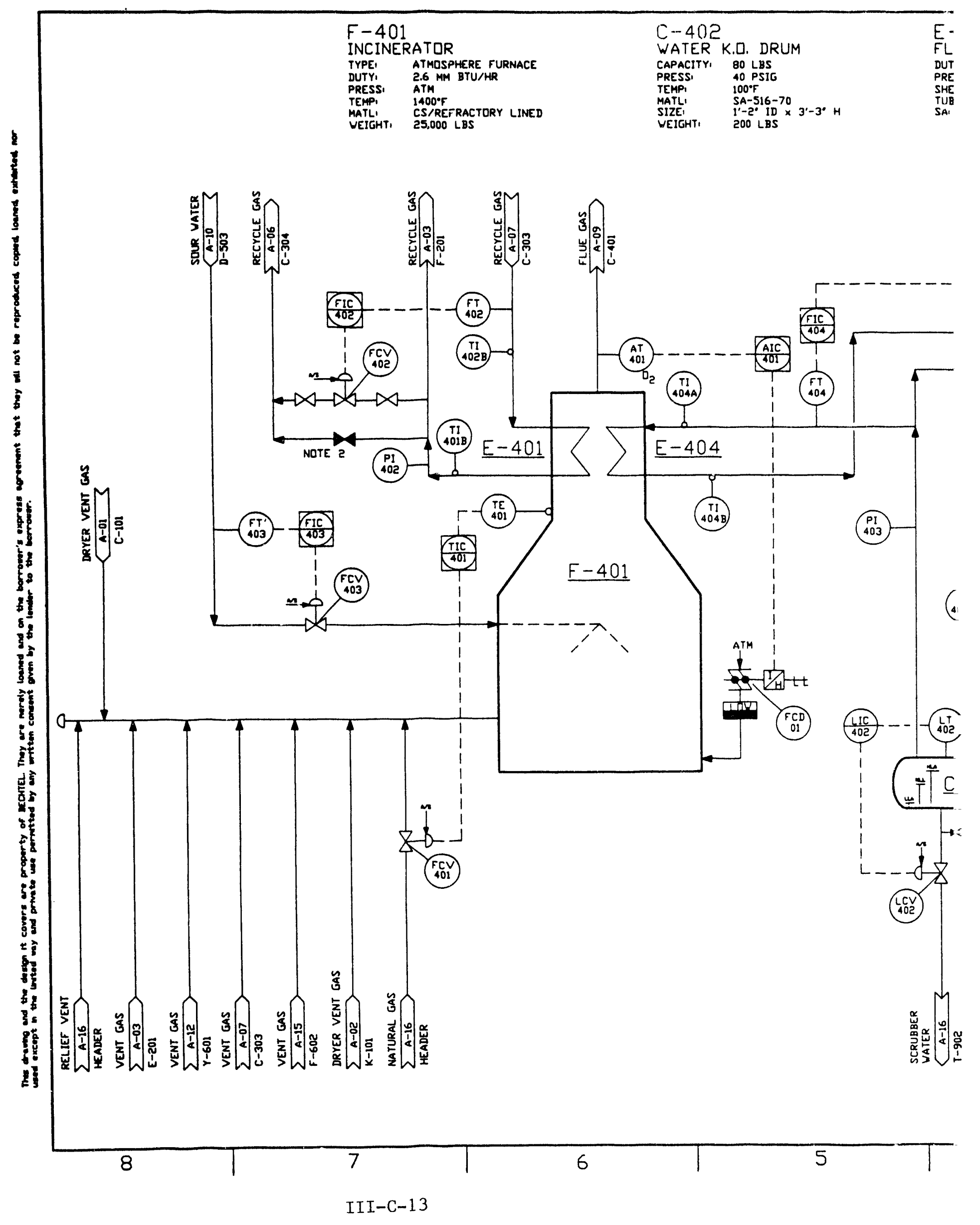


ㅁ. DRUM

80 LBS

40 PSIG

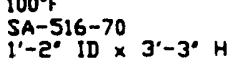

200 LBS
$E-405$

FLUE GAS CODLER

DUTY $\quad 1.36$ MM BTU/HR

PRESSI

SHELL MATL'

$\begin{array}{ll}\text { SHELL MATL1 } & \text { CS } \\ \text { TUBE MATLI } & \text { ADMRALITY } \\ \text { SAI } & \text { BOO SO FT }\end{array}$

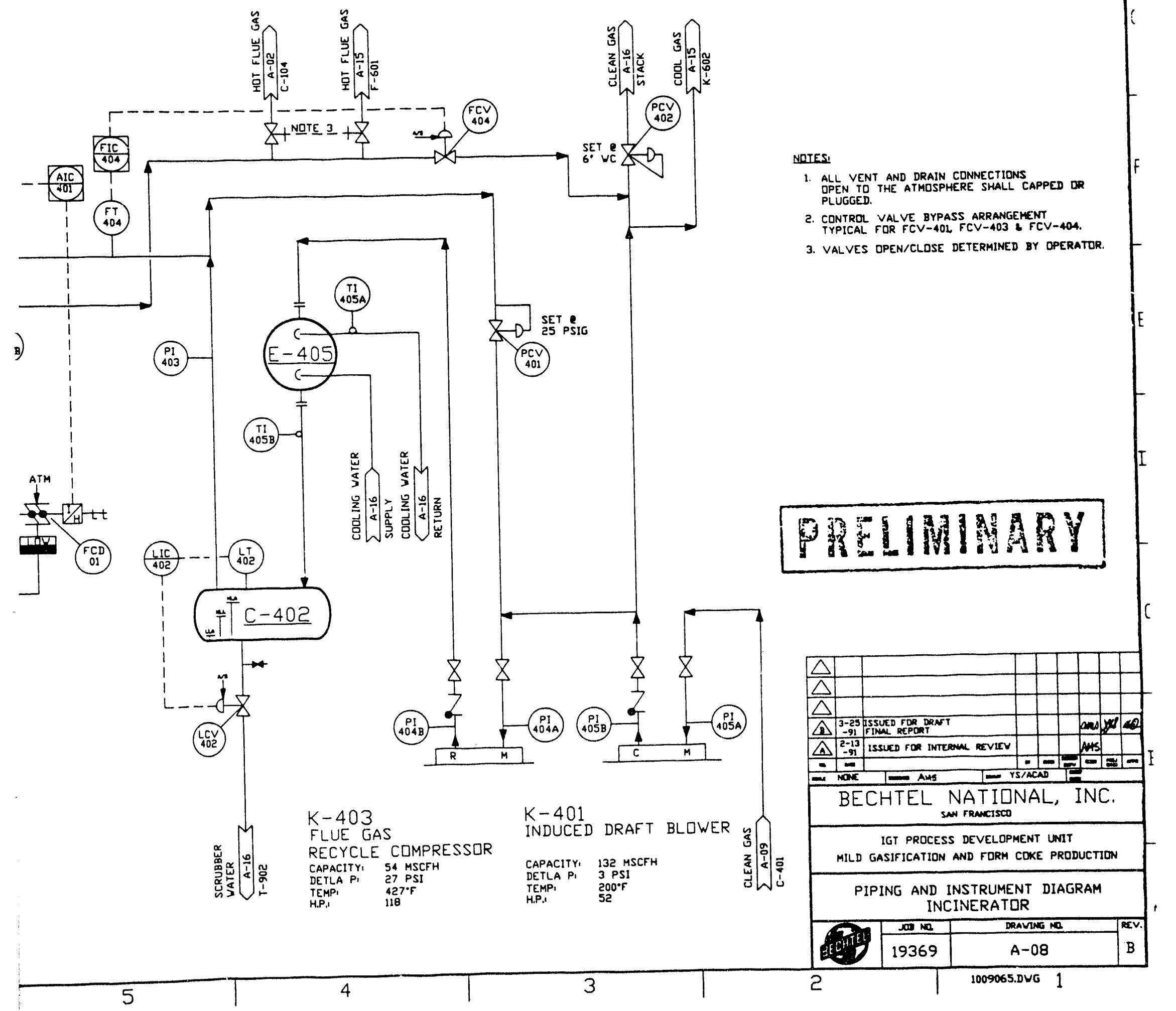




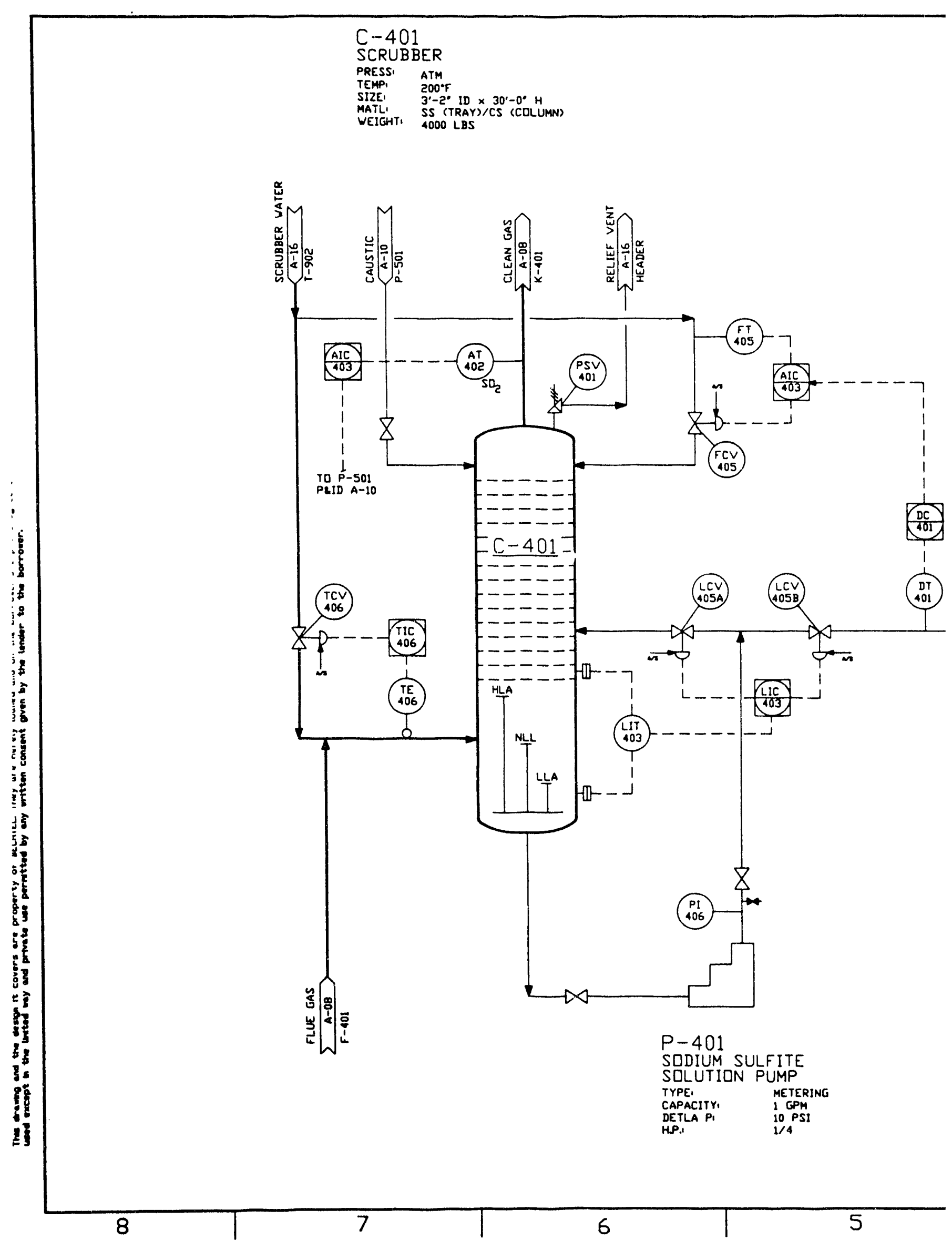


$E-402$

SODIUM SULFITE

SOLUTION COULER

DUTY, 213 MDTU/HR

TEMP $140^{\circ} \mathrm{F} / 100^{\circ} \mathrm{F}$ (SHELL

$90^{\circ} \mathrm{F} / 120^{\circ} \mathrm{F}$ (TUBE)

MAIL 18 CR-8 NI (SA-240)

38 SQ FT

405
5
5

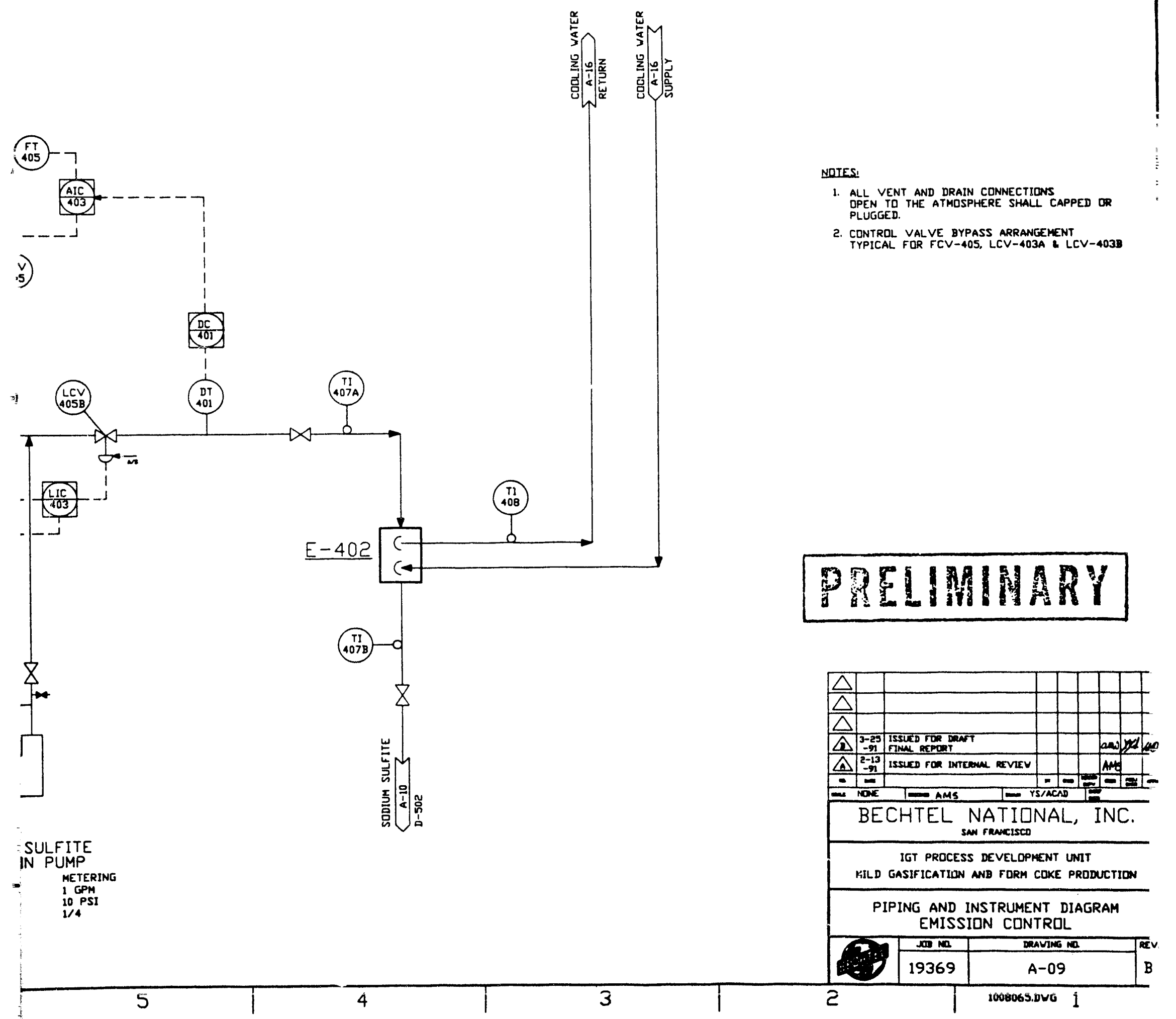




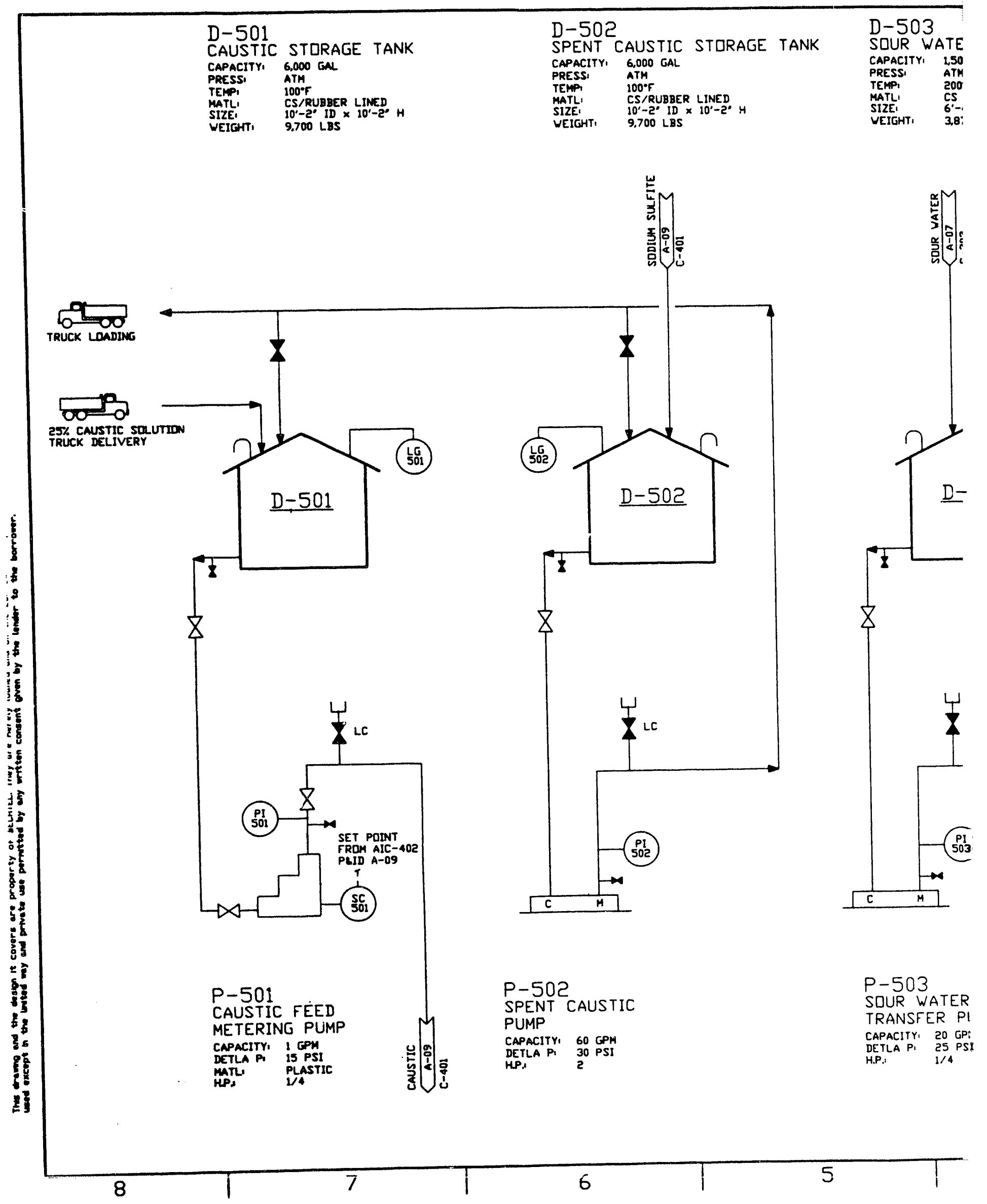


E TANK D-503

SOUR WATER STIRAGE TANK

CAPACITYY 1.500 GAL

PRESSI ATM

MATL $\quad$ CS

SIZEI $\quad 6^{\prime}-4^{\circ}$ ID $\times 6^{\circ}-4^{\circ} \mathrm{H}$

VEIGHTI 3.870 LBS
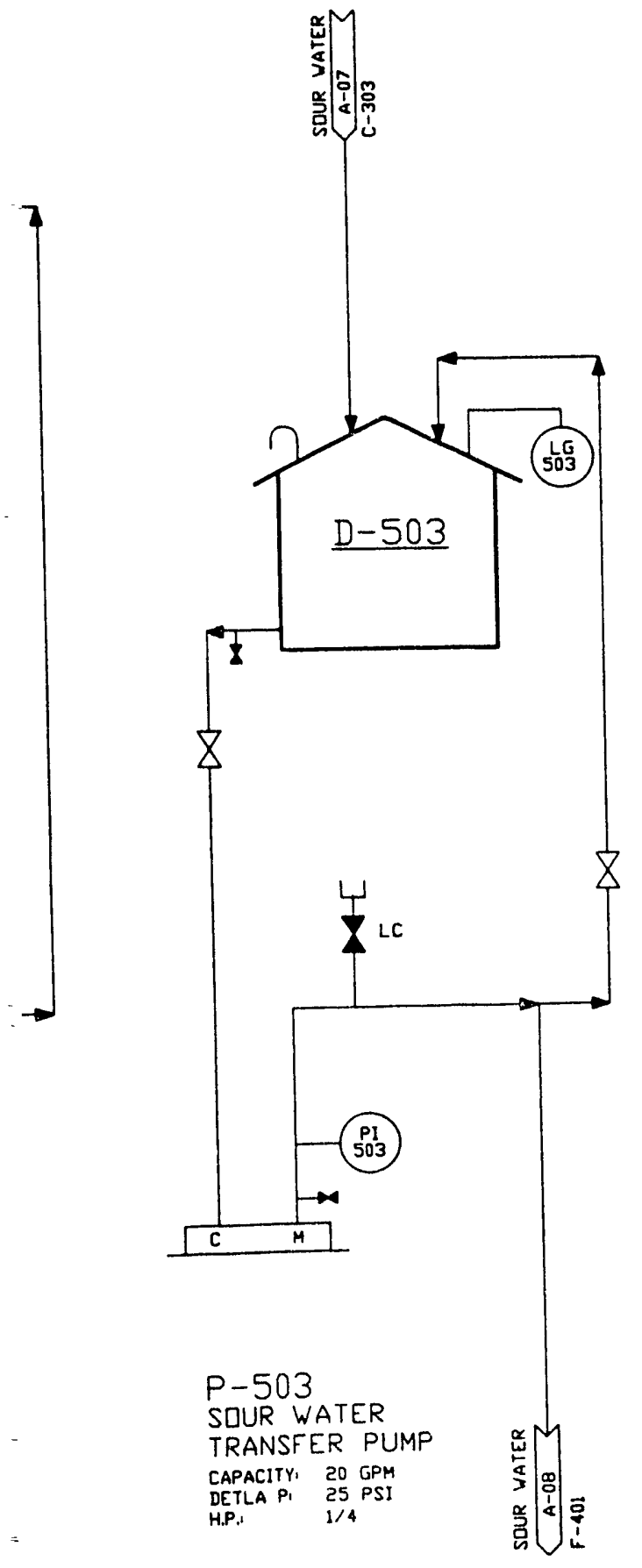

$D-602$

LIGNDSULFONATE SOLUTION

STIRAGE TANK

CAPACITY 500 GAL

PRESSI IS PSIG

TEMPI $\quad$ 100

MATLI CS

1860 LBS

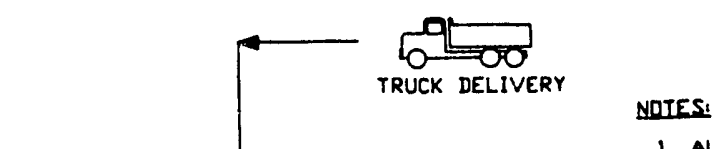

1. ALL VENT AND DRAIN CONNECTIONS

OPEN TO THE ATMOSPHERE SHALL CAPPED DR PLUGGED.
$P-601$

LIGNOSULFINATE SOLUTION PUMP $\begin{array}{lll}\text { CAPACITY } & 30 \text { GPM } \\ \text { DETLA } P_{1} & 30 \mathrm{PSI}\end{array}$ D.P.

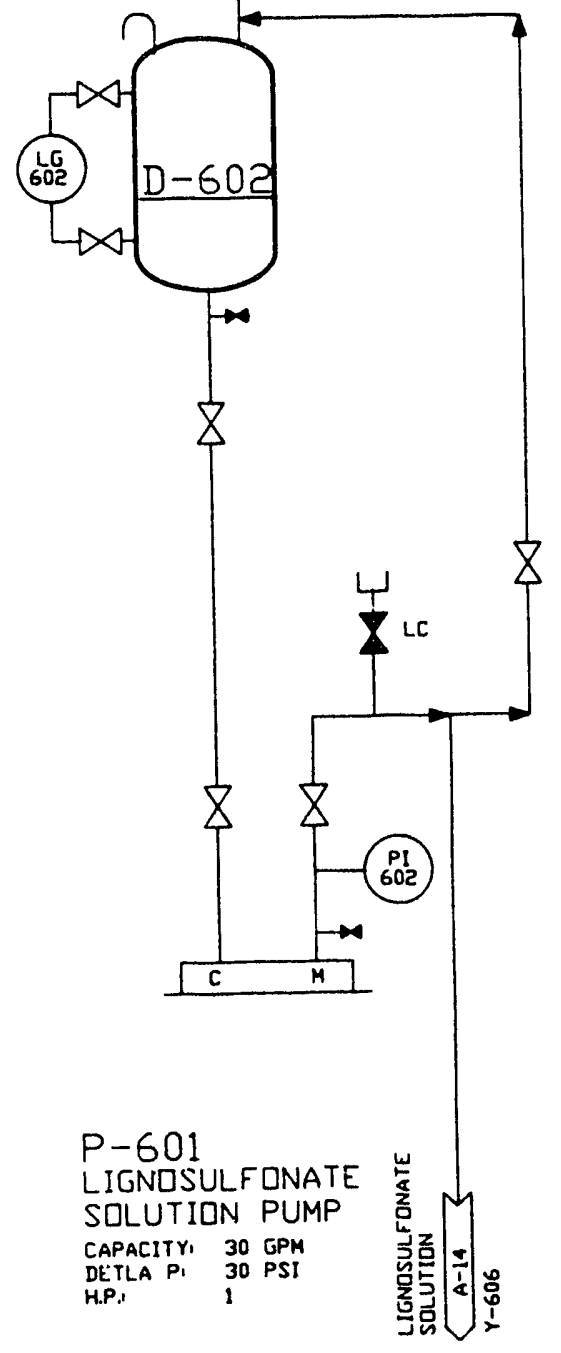




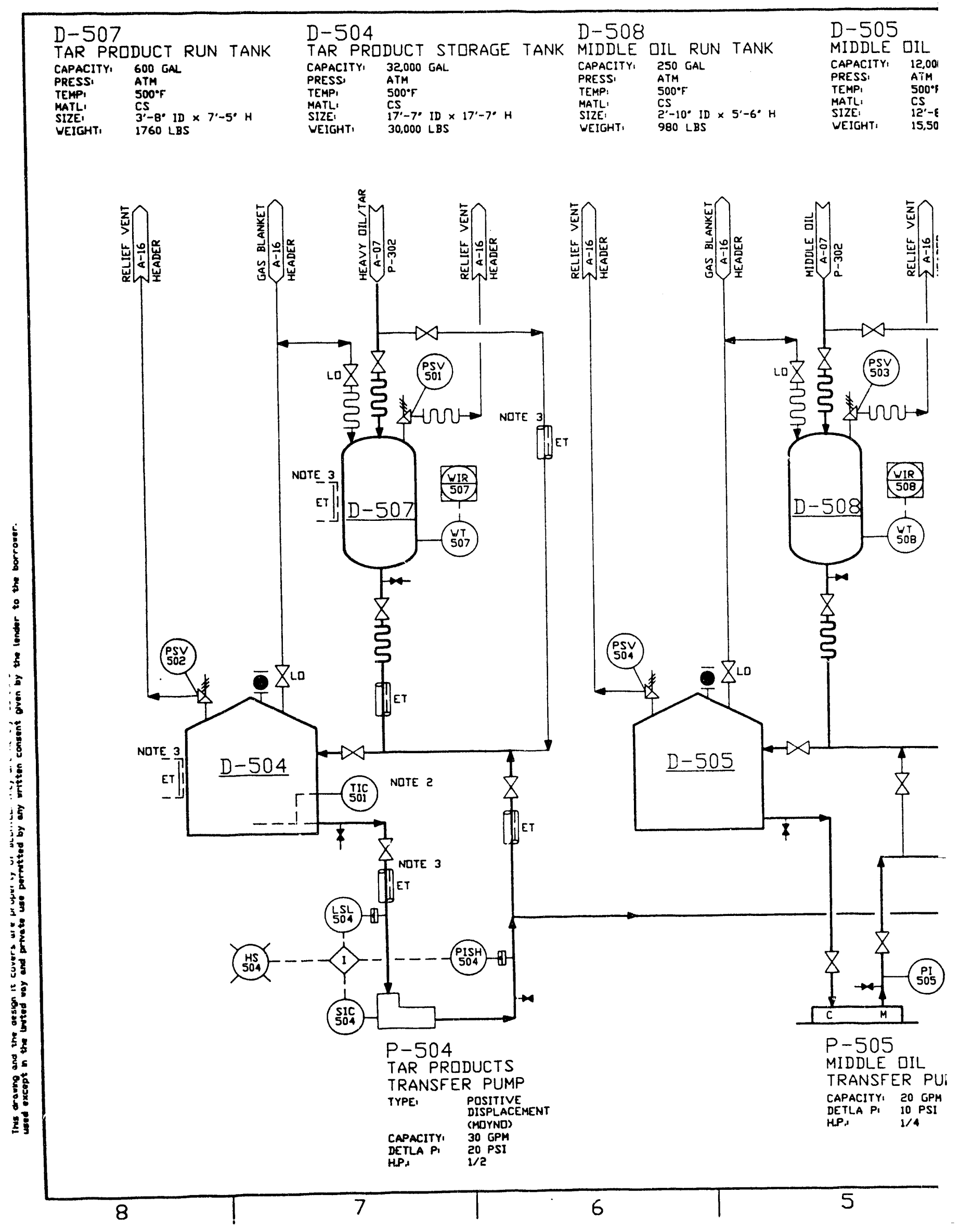




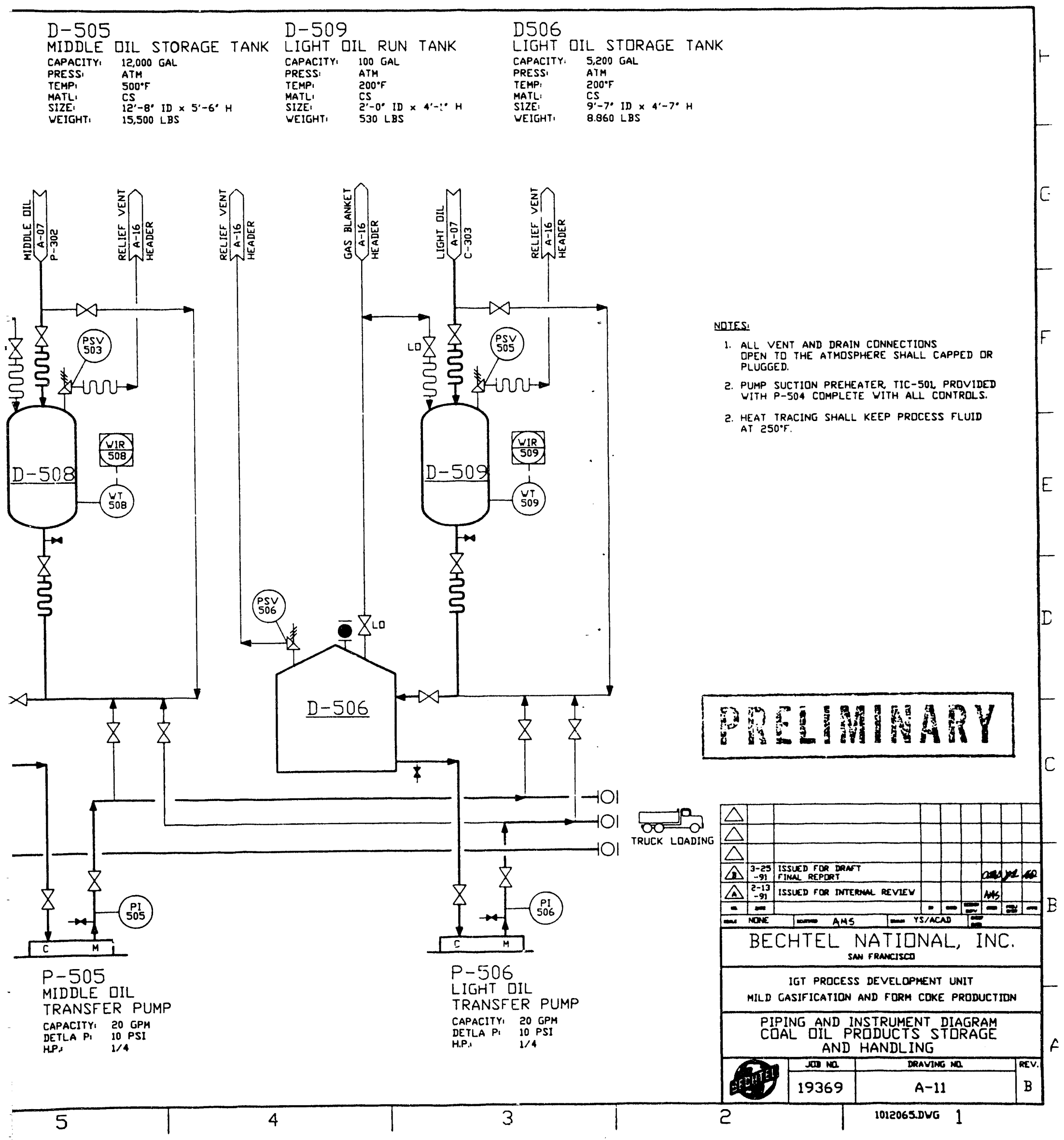




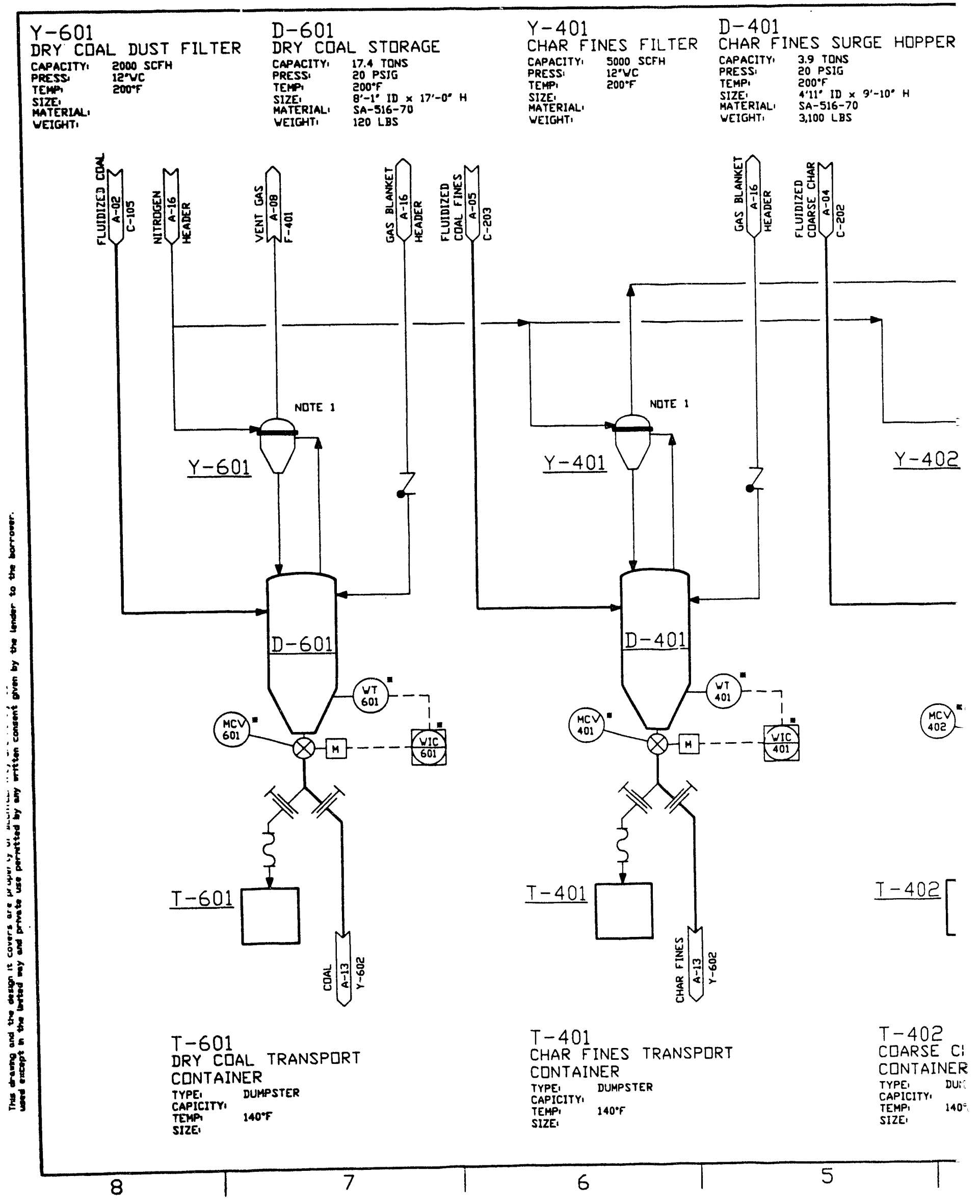




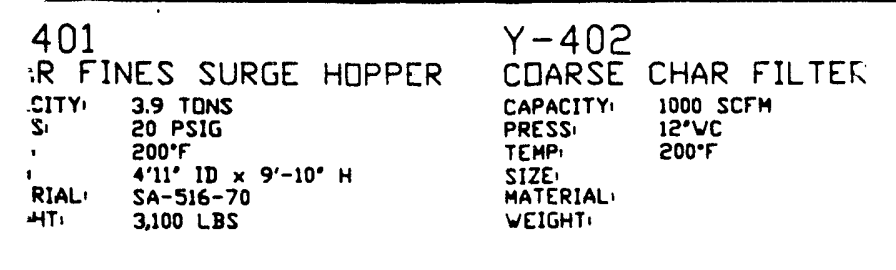

$D-402$

CDARSE CHAR SURGE HDPPER

CAPACITY 13.5 TONS

CRESS

TEMPI

$200^{\circ} F$

1. $-5^{\circ}$ ID $\times 14^{\prime}-10^{\circ} \mathrm{H}$

VEIGHTI 7.050 LBS
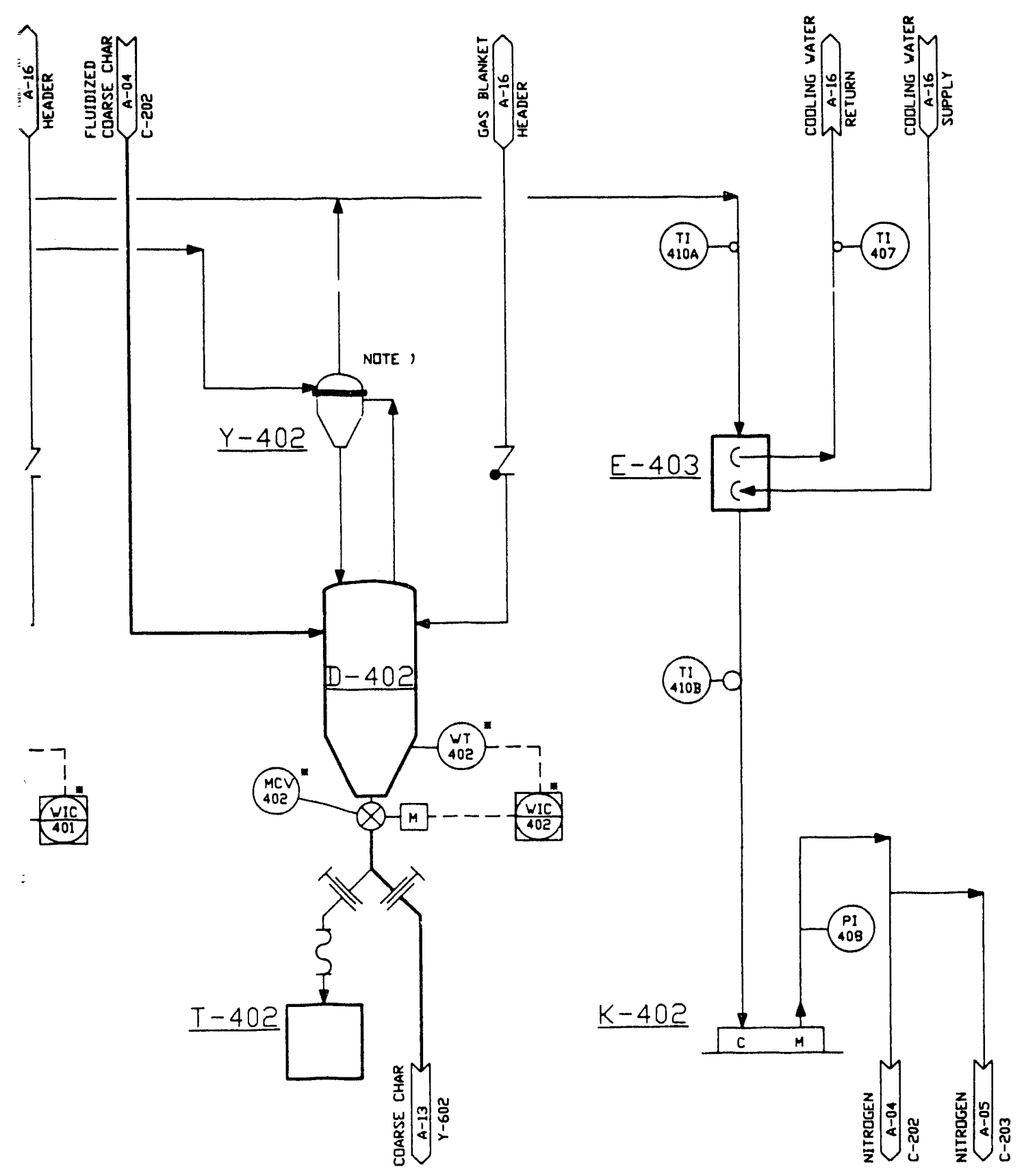

$E-403$

NITRDGEN CODLER

DUTY: I MBTU/HR

NOTES.

1. ALL INSTRUMENTS CONTROLS AND VALVES PROVIDED WITH EQUIPMENT ITEM.

. DENOTES ITEM IS PROVIDED WITH EQUIPMENT ITEM.

3. ALL VENT AND DRAIN CONNECTIONS QPEN TO THE ATMOSPHERE SHALL CAPPED DR PLUGGED.

$T-402$

COARSE CHAR TRANSPDRT

CONTAINER

TYPE, DUMPSTER

CAPICITY, $140^{\circ}$

TEMPI

$K-402$

NITROGEN BLOWER

CAPICITY, 650 SCFH

$\begin{array}{ll}\text { DELTA } P_{1} & 6 \text { PSI } \\ \text { HPI } & 1 / 2\end{array}$

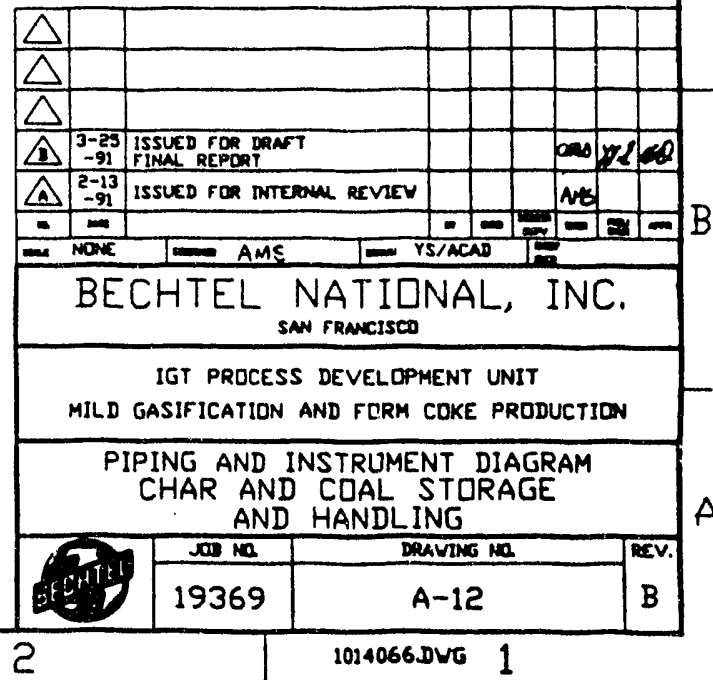




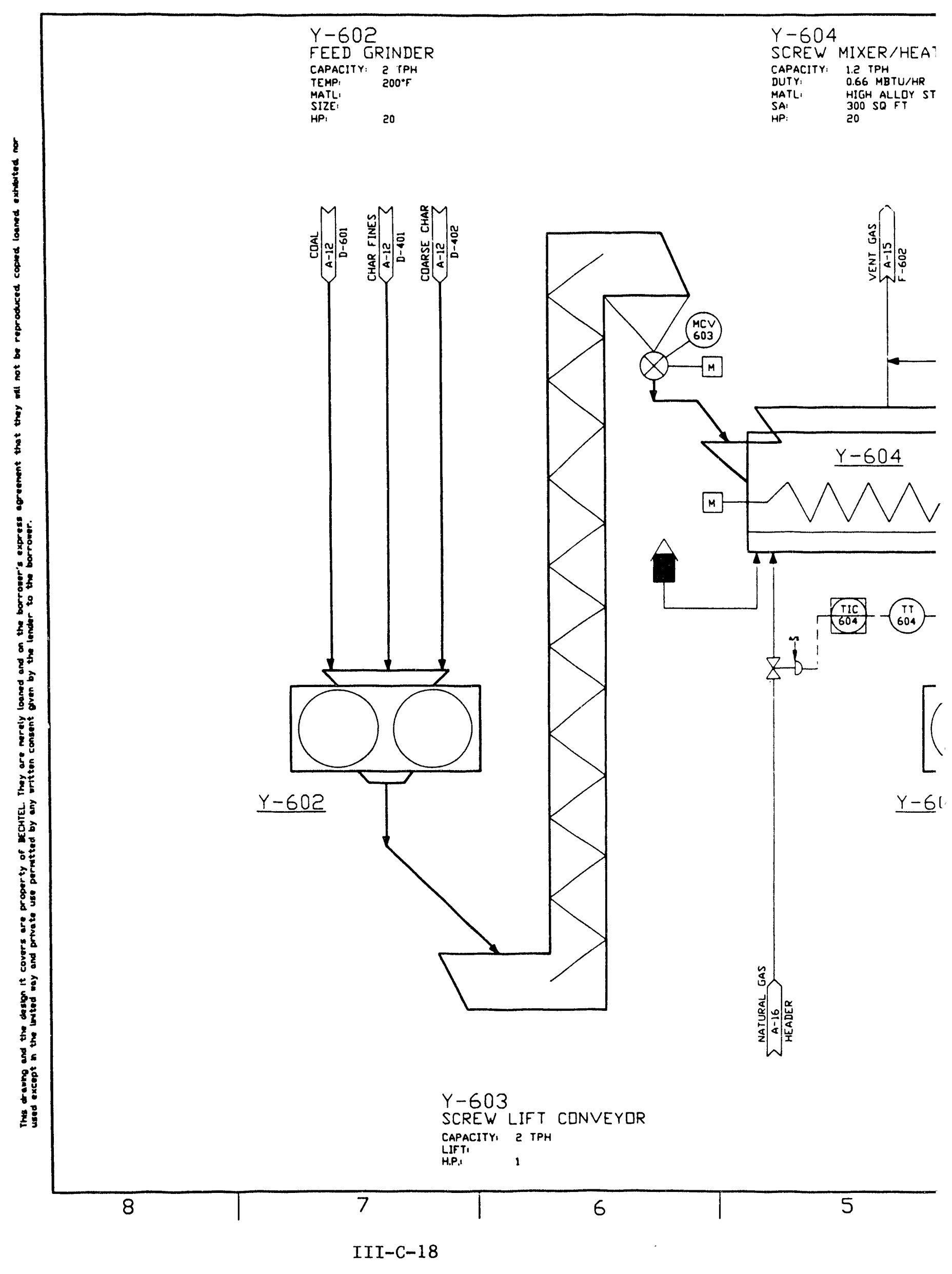


$Y-605$

HOT RDLL BRIQUETTER

-1IXER/HEATER

$1.2 \mathrm{TPH}$

CAPACITY:

$\begin{array}{ll}\text { PRESS: } & \text { ATM } \\ \text { TEMP1 } & 1000^{\circ} \mathrm{F}\end{array}$

MATL $1000^{\circ} \mathrm{F}$

HIGH ALLOY STEEL

300 SO FT

SIZE:

so

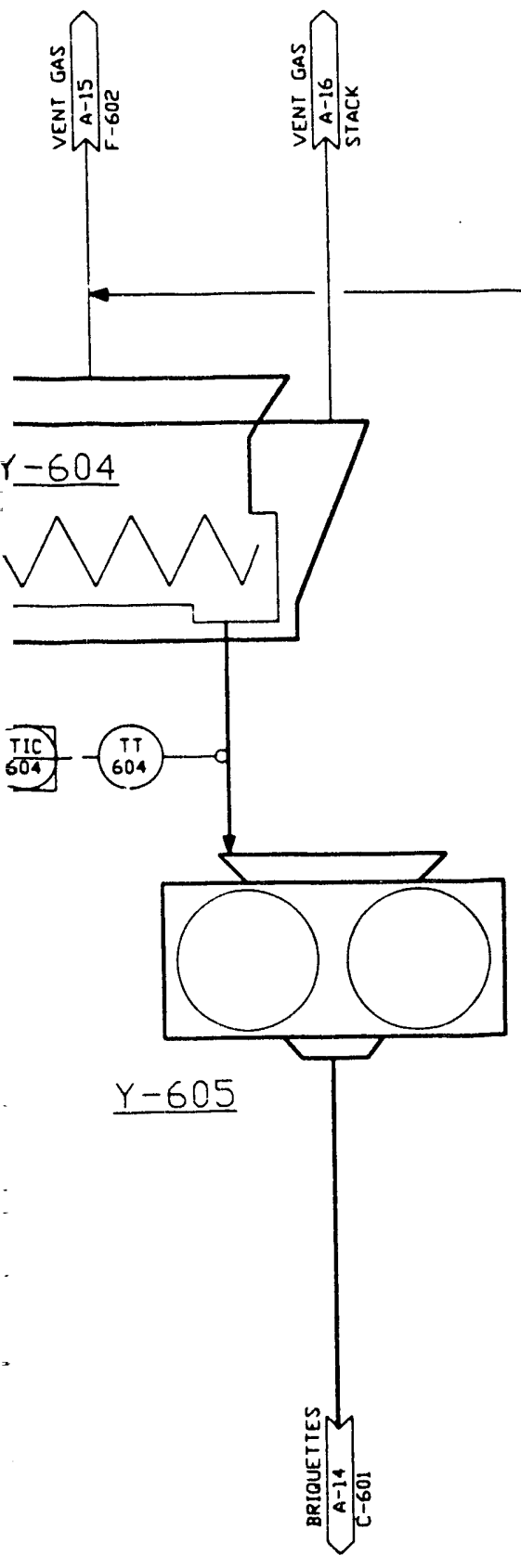

为 5 5'

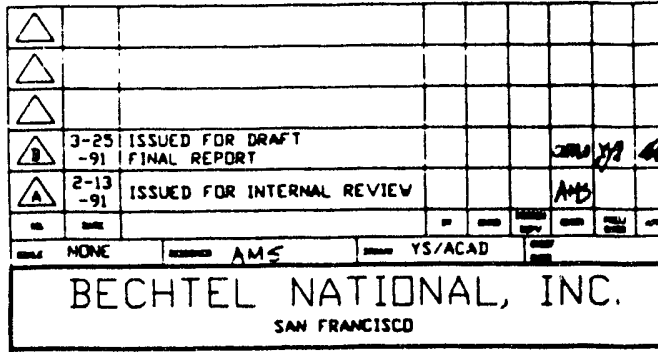

IGT PROCESS DEVELOPMENT UNIT MILD GASIFICATION AND FORM COKE PRODUCTIDN

PIPING AND INSTRUMENT DIAGRAM BRIQUETTE FORMING

\begin{tabular}{|c|c|c|}
\hline 7 & $003 \mathrm{NB}$ & Deavtiog na \\
\hline Est? & 19369 & $A-13$ \\
\hline
\end{tabular}




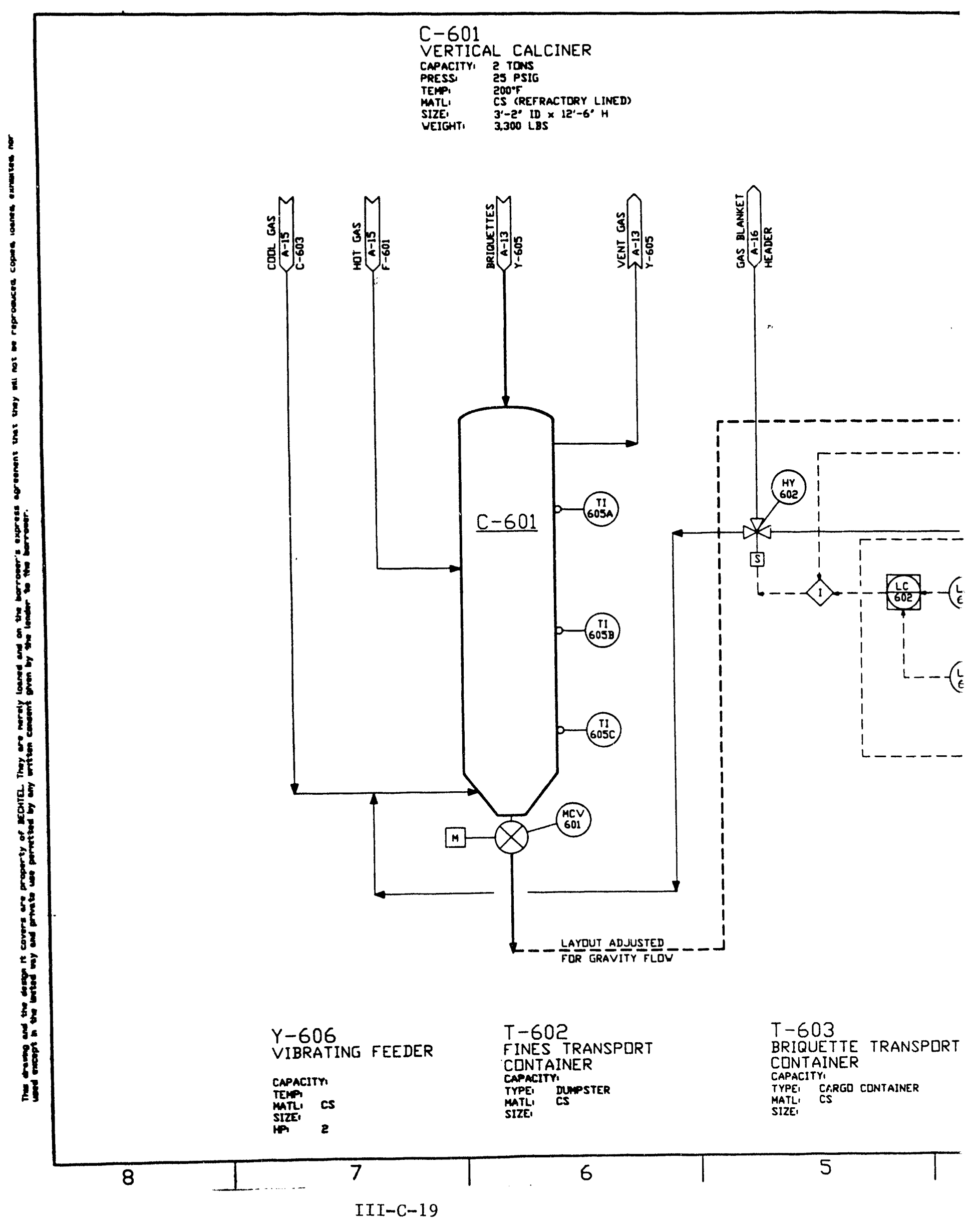




$$
\text { c-602 }
$$

LDCK HDPPER

CAPACITY, 0.56 TONS

PRESS 20 PSIO

$\begin{array}{ll}\text { TEMP, } & 500^{\circ} \\ \text { MTLI } & \text { CS }\end{array}$

SIZE, $\quad 5_{1}-7 \circ$ ID $\times 2_{2}-5^{\prime} H$

VEIGHTI BSO LBS

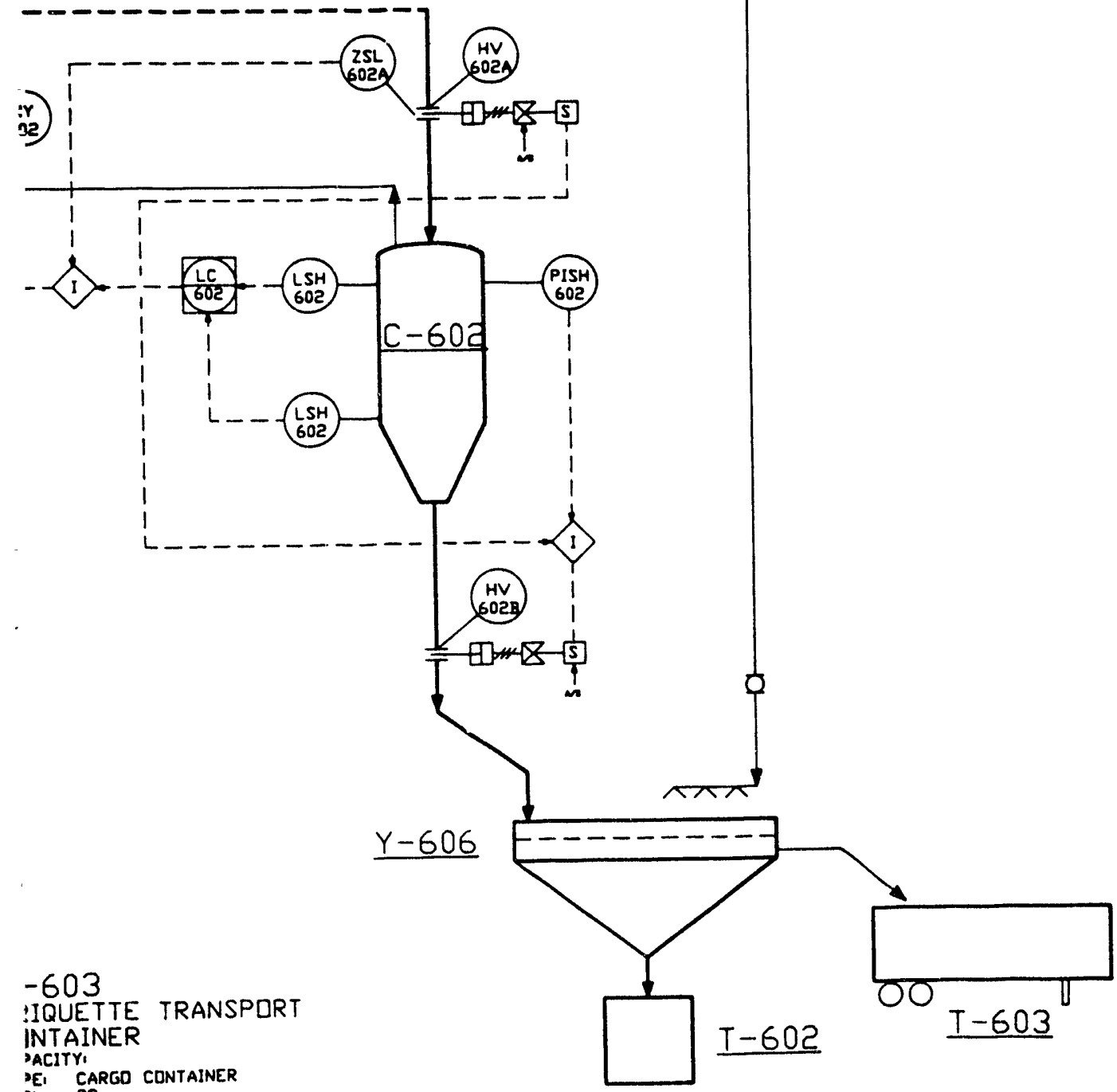

\section{PRELIMINARY}

'EI CARGD CDNTAINER

:

\begin{tabular}{l|l}
5 & 4
\end{tabular}

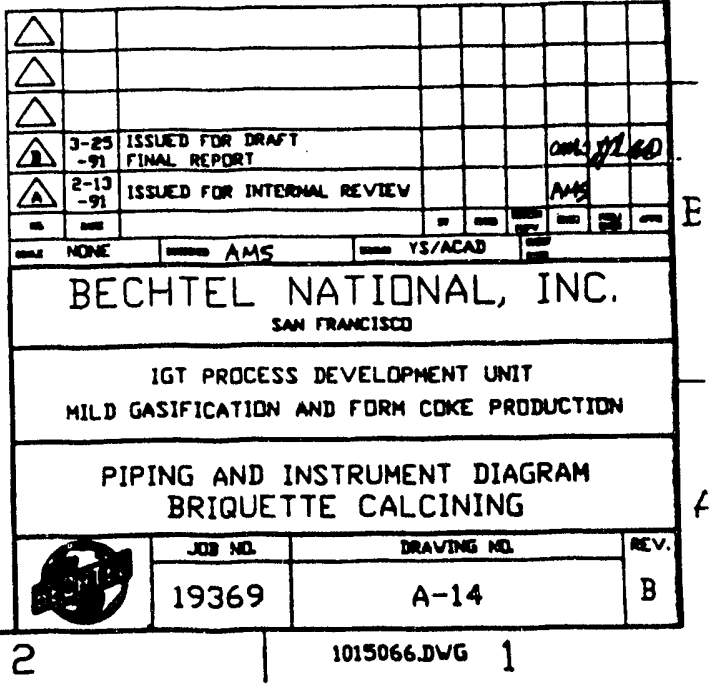




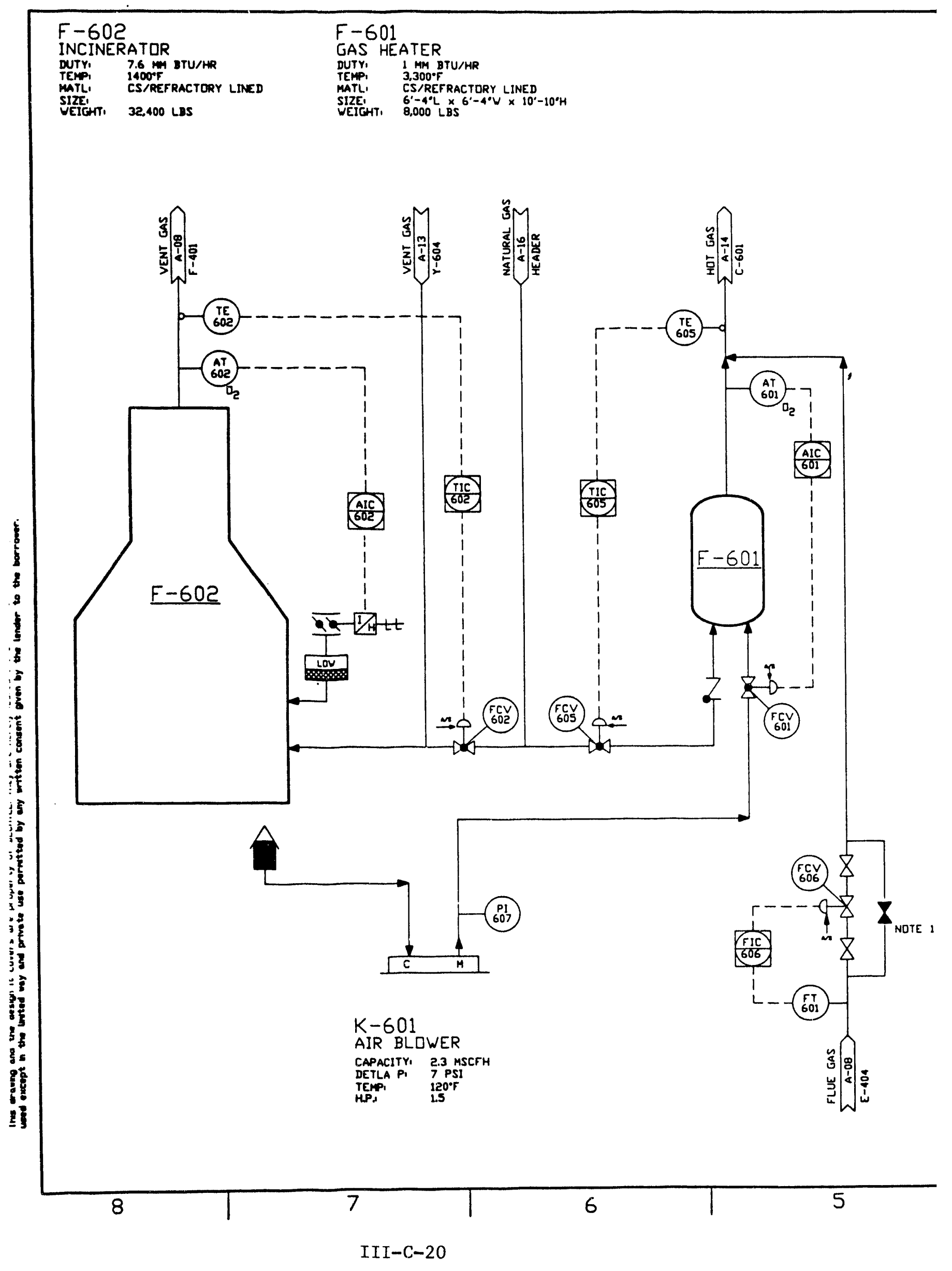




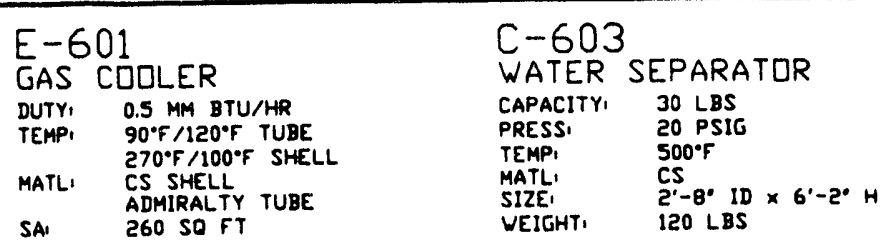

J
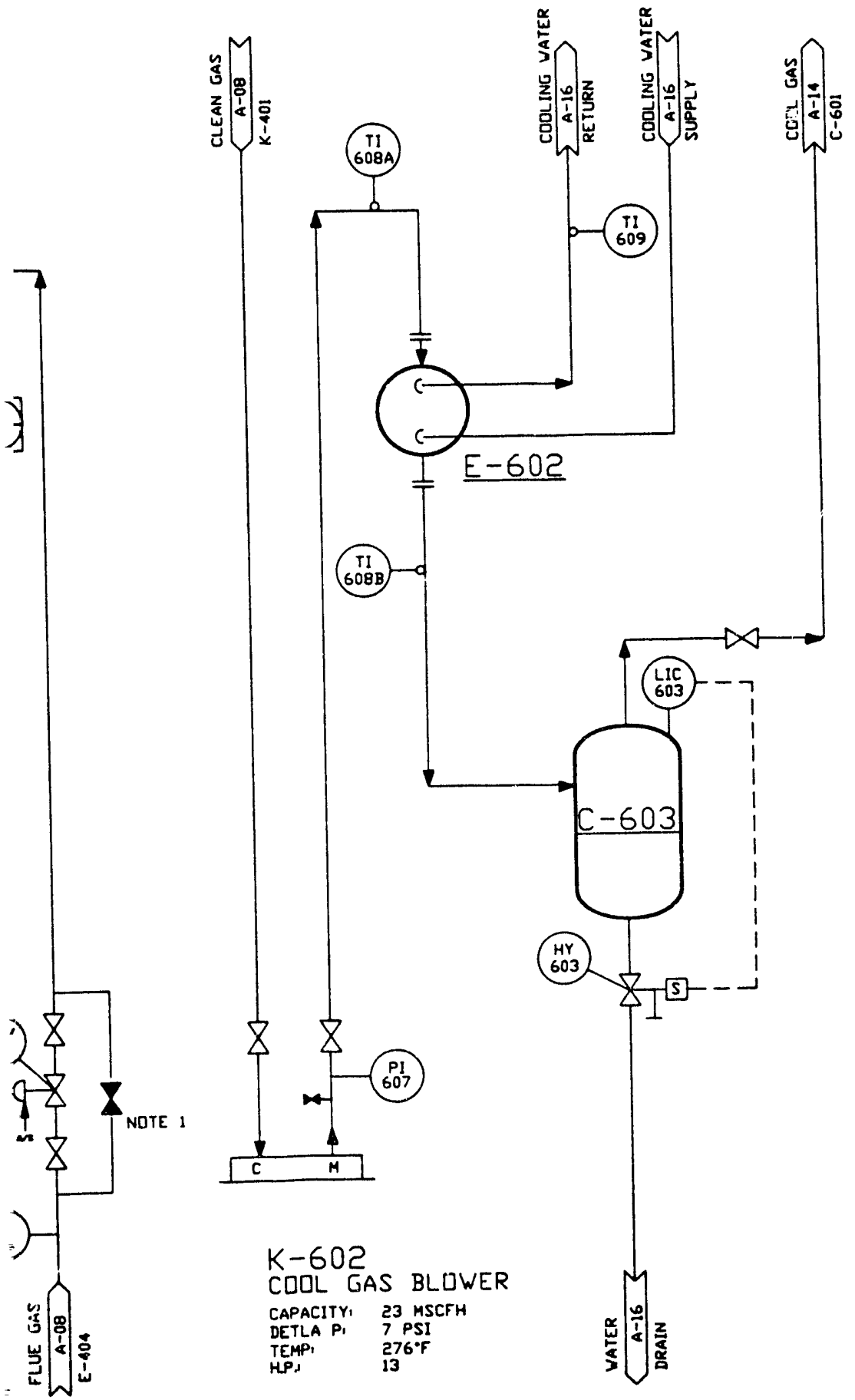

NDYES:

1. CDNTROL VALVE BYPASS ARRANGEMENT TYPICAL FOR FCV-602 FCV-602 \& FCV-605

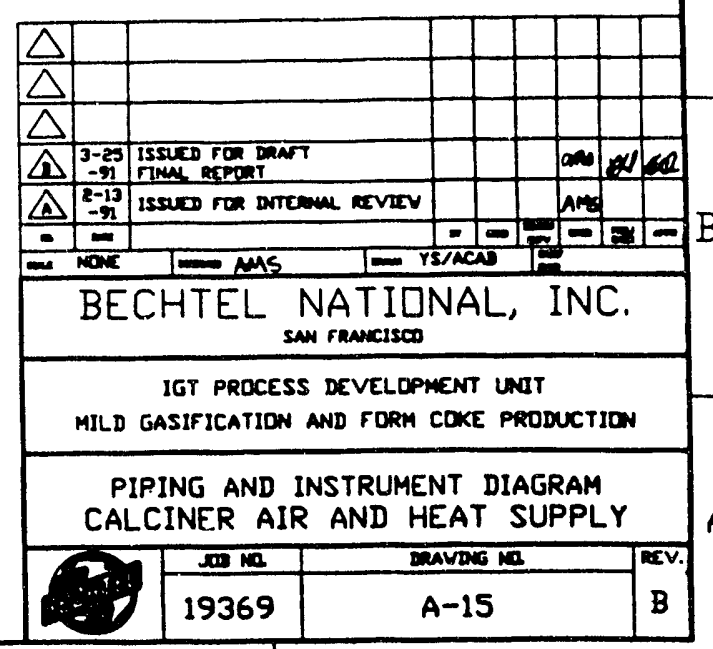

1016066.DVO 1 


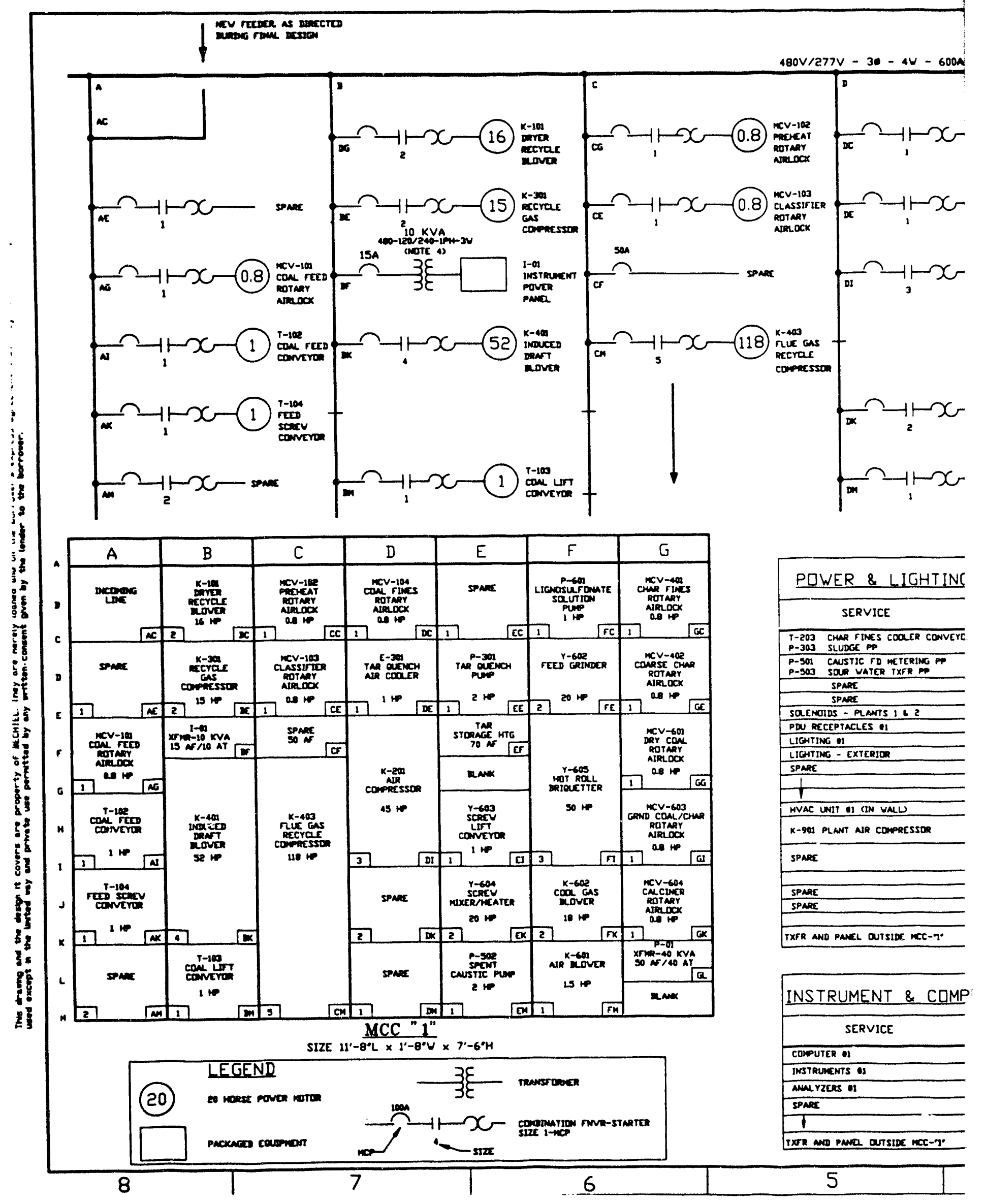

III-C-21 
$480 V / 277 V-30-4 W-$ GODA BUS - MCC $1{ }^{\circ}-25,000$ AIC

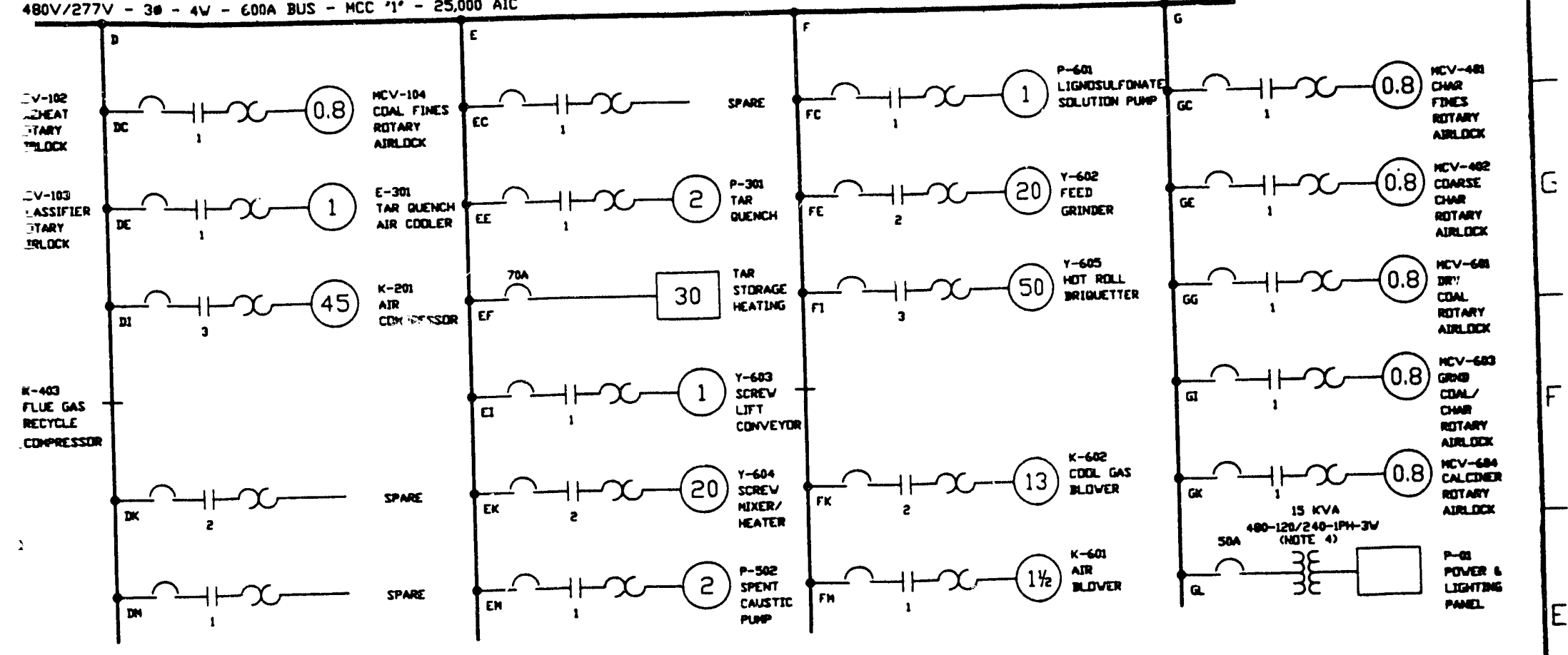

\begin{tabular}{|c|c|c|c|c|c|c|c|}
\hline \multicolumn{3}{|c|}{ POWER \& LIGHTING PANEL } & \multicolumn{5}{|c|}{ 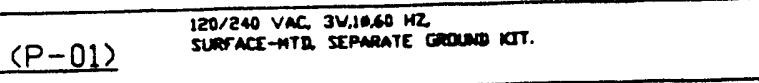 } \\
\hline SERVICE & \multicolumn{2}{|c|}{ CKT BKR } & $\frac{\text { LOAD }}{V}$ & $\frac{\text { LDAD }}{W}$ & \multicolumn{2}{|c|}{ CKT BKR } & SERVICE \\
\hline $\begin{array}{l}\text { T-203 CHWR FINES CDOLER COAVEYOR } \\
\text { P-303 SLUDCE PP }\end{array}$ & 1 & 15 & $\frac{v}{400}$ & $\frac{V}{400}$ & 15 & A & \begin{tabular}{|l|l|}
$E-302$ & MIDDEE OLL OUENOH AIR COOLER \\
P-401 & SODIUM SULFITE SOLN PP \\
\end{tabular} \\
\hline 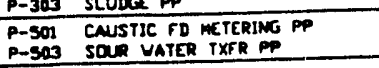 & 1 & 15 & 400 & 400 & 15 & 1 & 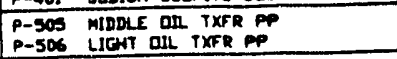 \\
\hline SPARE & 1 & 15 & 0 & 0 & 15 & 1 & SPAPE \\
\hline SPAPE & 1 & 15 & 0 & 0 & 15 & 1 & SPARE \\
\hline SOENOIDS - PLANTS IL? & 1 & 15 & 600 & 600 & 15 & 1 & SQLENOIDS - PLANTS 3 TQ \\
\hline PDU RECEPTACLES :I & 1 & 20 & 1600 & 1600 & 20 & 1 & $\begin{array}{l}\text { PDU RECEPTACESS OR } \\
\end{array}$ \\
\hline LIGATING $n$ & 1 & 15 & 1200 & 1200 & 15 & 1 & LIOHTIMG of \\
\hline LICHTIEC - EXTERIDO & 1 & 20 & 1600 & 1600 & 15 & 1 & LIGATIHE - MCC/CONTROQ ROOON \\
\hline SPAAR & 1 & 20 & 0 & 0 & 20 & 1 & SPAME \\
\hline$\frac{\operatorname{sinas}}{1}$ & & & & $T$ & $T$ & $T$ & \\
\hline & $T$ & 7 & T & $t$ & T & t & tr \\
\hline HVAC UNI OI CIN VALL & 2 & 40 & 3600 & 3600 & $\$ 0$ & 2 & HVAC UNIT DE (IN VALL) \\
\hline K-900 PLANT AIR COMPRESSDR & 2 & 40 & 2600 & 1000 & 25 & 2 & 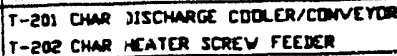 \\
\hline SPARE & e & 20 & - & 1000 & is & 2 & 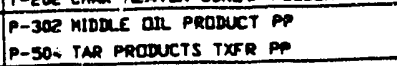 \\
\hline & & & & & & & \\
\hline SPAPE & 2 & $\$ 0$ & 0 & 0 & 40 & 2 & SPARE \\
\hline$\frac{\text { SPAat }}{\text { SPAPC }}$ & & & & & & & SPARE \\
\hline & & & & & & & \\
\hline TXFR A:D PAMEL & & & TOTA D & $x v a$ & & & \\
\hline
\end{tabular}

meres

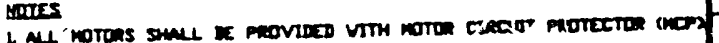

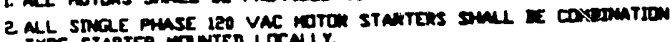

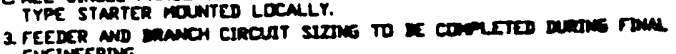

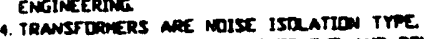
4. TRANSFDREERS ARE MOISE IsRLATLON TrFe.

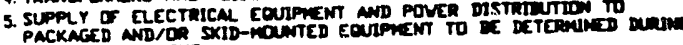
FIMUL ENGINEERING 6. CoNTRQ SCHEMATICS

7. PROACCTED COMARECTED LOAD - 43 KVA

DEMaND = $393 \mathrm{KVA}$

\section{PRIMIMINARY}

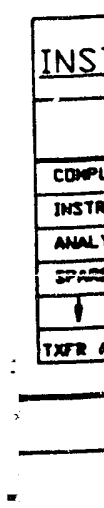$$
\begin{array}{|l}
\hline \text { INS } \\
\hline \\
\hline \\
\hline
\end{array}
$$

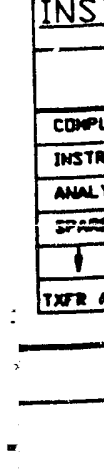$$
\begin{array}{|l}
\hline \text { INS } \\
\hline \\
\hline \text { conpl } \\
\hline \text { InSTR } \\
\hline \text { muec } \\
\hline 5 \\
\hline 1 \\
\hline
\end{array}
$$

\begin{tabular}{l|l}
5 & 4 \\
\hline
\end{tabular}

TOTAL Denimo $64 \mathrm{KVA}$ 4

\begin{tabular}{|c|c|c|c|}
\hline LDAD & & BKP & SERVICE \\
\hline$w$ & $p$ & $A$ & \\
\hline 1200 & 15 & 1 & COMPUTER U2 \\
\hline$\infty 00$ & 1 & 1 & INSTRUENTS az \\
\hline$\infty$ & & & AMG YZZER 12 \\
\hline 0 & & & SPAAK \\
\hline 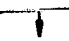 & i & $i$ & 1 \\
\hline
\end{tabular}

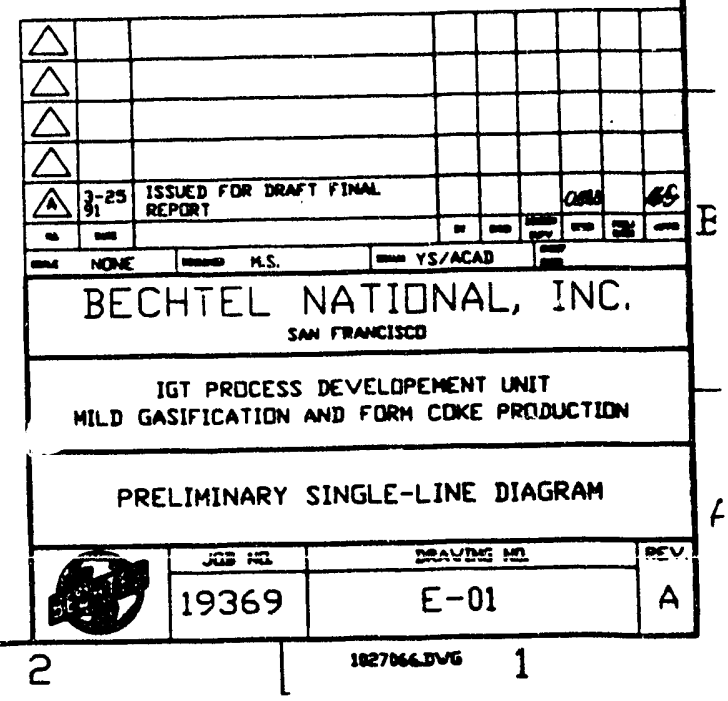


APPENDIX D. PDU Cost Savings Opportunities 
During the development of the P\&IDs, modifications with a potential for reducing the procurement, installation, and operating costs of the PDU were noted. These modifications are documented below and should be considered in the final facility design.

\section{Modifications}

1. Eliminate the coal feed lock hopper $(C-101)$ and use the coal feed hopper $(Y-104)$ as a loss-in-weight feeder to the system

2. Procure the coal and char handling, drying, preheating, and storage as packaged units

3. Replace the coal-oil product storage tanks (D-504, D-505, and D-506) with DOT-approved trailers. Trailers may also be provided by the refinery/ research organization investigating the commercial use of the products as a part of a separate agreement. Otherwise. an allowance for trailer rental will need to be added.
Remarks

Coal can be metered into the system with sufficient accuracy for material balance calculations from the feed hopper. The coal feed lock hopper is then redundant and can be eliminated

Delivering feed to gasifier at the required temperature and pressure will present a significant engineering challenge. Procuring these units as systems will allow a greater degree of participation by vendors in the design phase and thereby make better use of their experience

Reduces capital costs and space requirements

Allows for an easier permitting of facility operating since products are not stored on site

Storage, evaluation, and disposal of products can probably be done better at an existing refinery and/or hydrocarbon research center. Early identification of such a facility elimiantes the possibility that no such facility can be found after PDU operation and that the material (especially tar/pitch product) will then have to be disposed of as hazardous waste 
4. If Recommendation 3 is not acceptable, reduce the requirement for 6 months of storage capacity of coal-oil products at the site

5. Use the cooled combustion products out of the water knowkcout drum (C-402) for purging, gas blanketing, and other inert gas service

6. Investigate the use of $D O E$ excessed property
Reduce capital costs, notably of that of the tar product storage tank (D-504)

\footnotetext{
May ease permitting requirements if these are defined as a function of duration and/or amount of of storage

Reduces the potential for work needed to separate gasification products from products suitable for sale or use by others. This is accomplished by not mixing products of startup from those intended for commercial use

Reduces or eliminates the need for nitrogen

A larger flue gs cooler (E-405) and a new receiver may be required

May reduce cost, but costs for reconditioning equipment and availability of the equipment must be considered
} 


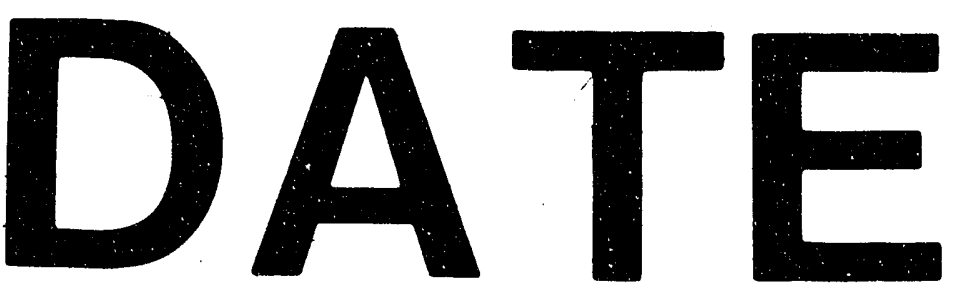

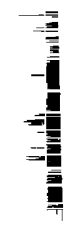
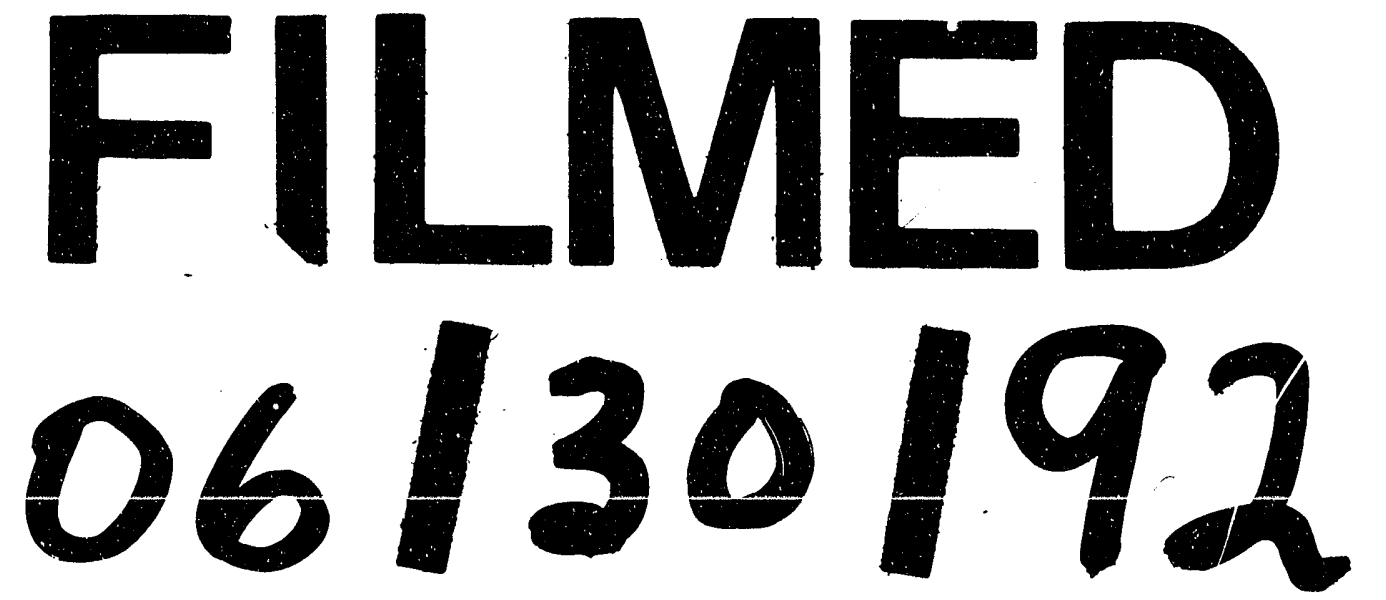
